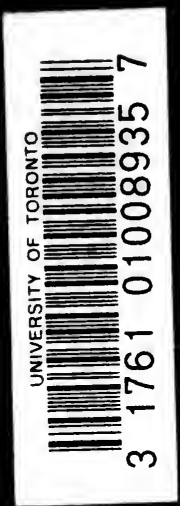





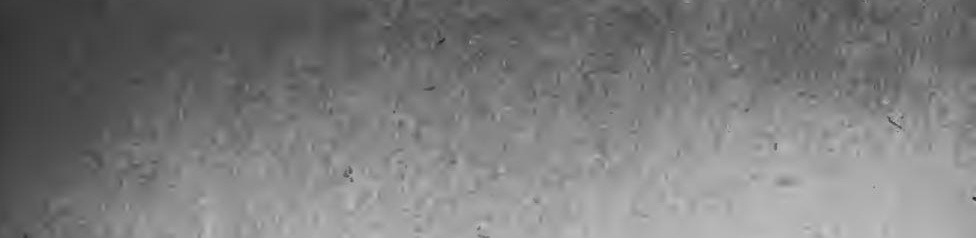

1. $-9=0$
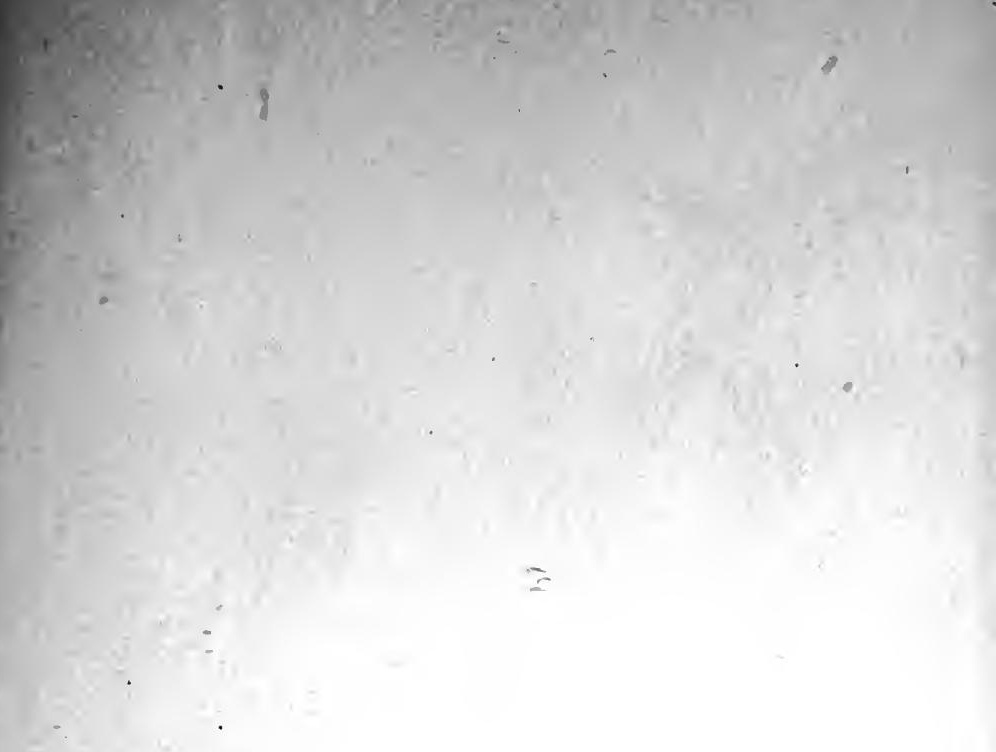

in

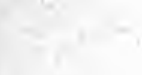

5.

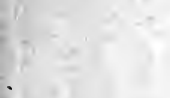

-

(1)

1

.

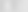


Digitized by the Internet Archive in 2007 with funding from Microsoft Corporation 

THE STUDENTS' SERIES OF HISTORICAL AND COMPARATIVE GRAMMARS EDITED BY JOSEPH WRIGHT 


\title{
HISTORICAL \\ GERMAN GRAMMAR
}

VOL. I

PHONOLOGY, WORD-FORMATION AND ACCIDENCE

\author{
BY \\ JOSEPH WRIGH'T \\ PH.D., D.C.L., LL.D., LITT.D. \\ FELLOW OF THE-BRITISH ACADEMY \\ PROFESSOR OF COMPARATIVE PHILOLOGY IN THE \\ UNIVERSITY OF OXFORD
}

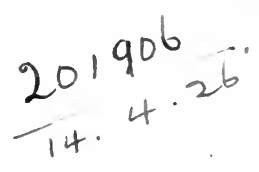

HENRY FROWDE

OXFORD UNIVERSITY PRESS

LONDON, NEW YORK AND TORONTO 
OXFORD : HORACE HART

PRINTER TO THE UNIVERSITY

ELECTACAVE VESTON

AVALAEE

$$
\frac{N 0.01001270}{\text { UTL-354A }}
$$

PRANTEO IR ENOLARO. 


\section{PREFACE}

IT is a noteworthy fact that during the last few years there has been a steady increase in the number of people who take a real interest in the scientific study of language. The comparatively small number of such people, and the backward state of knowledge on the subject, are not due to lack of desire to learn, but chiefly to the lack of suitable handbooks written in English. In order therefore to meet this want, it has long been my intention to edit a series of grammars which shall give for each language a concise account of its phonology, morphology, inflexions and syntax from an historical point of view. I was unable to develop this scheme whilst working at the English Dialect Dictionary; but now that I am free from those labours, I am able to devote my whole time and energy to the furtherance of the project. This book then is the first of the series of historical grammars. Although it has been compressed into a comparatively small compass, I venture to think that it is the most complete treatise on historical German grammar which has hitherto appeared in the English language. A glance at the Index of over 4,000 words will show that I have not shirked the drudgery of collecting large numbers of examples to illustrate the sound-laws in the different periods of the language, and more especially those in the modern period.

A student, who wishes to acquire a thorough knowledge of historical German grammar, should first make himself familiar with the older periods by reading through a certain number of texts such as those given in the Old and Middle 
High German Primers. By so doing, he will gain a much firmer grasp of the subject than if he merely works at a grammar. If he already possesses a fair vocabulary of Old and Middle High German, he will most certainly master the grammar in far less time than he would do, were he quite ignorant of the older periods of the language. However, in writing this book I have not presupposed even an elementary knowledge of Old and Middle High German on the part of students; but on the other hand it will be useless for anyone who has not already a fairly good knowledge of Modern German to attempt to read the book, because, in order to save space, I have omitted the meanings of the Modern German words, except in special cases where this might lead to confusion.

Although I have endeavoured to include all that the average student will require to know of the subject, I do not pretend that this grammar is in any sense an exhaustive treatise. To have treated the subject in great detail would have lessened the practical value of the book. A list of the chief books used in the writing of the grammar will be found on pp. xiii-xiv, but it is my pleasant duty to mention here my great indebtedness to the works of Behaghel, Braune, Paul, and Wilmanns.

Volume II, dealing with historical German syntax, will be written by my colleague, Dr. Fiedler, who hopes to have it ready for press early next year.

In conclusion, my sincere thanks are due to the Controller of the University Press for his great kindness in complying with my wishes in regard to special type, and to my wife for her valuable help in making the Index Verborum.

\section{JOSEPH WRIGHT.}

OXFord, April, 1907. 


\section{CONTENTS}

PAGES

INTRODUCTION

General principles ( $\$ \S I-5)$; classification of the Indo-Germanic languages, and a few characteristics of the Germanic languages (\$ 6); the periods of High German $(\$ 7)$; characteristics of Old, Middle and New High German $(\S 8)$; the High German dialects (§ 9).

\section{CHAPTER I}

Orthography and Pronunciation.

(I) The OHG. period: vowels ( $\$$ IO-I2); consonants ( $\left(I_{3}\right)$; phonetic survey of the OHG. soundsystem ( $\$$ I $^{-1}$-17). (2) The MHG. period: vowels (§ I8); consonants ( $\$$ I9-20). (3) The NHG. period: vowels (§21); consonants (\$22). Accentuation (\$§ 23-9).

\section{CHAPTER II}

The Prim. Germanic Equivalents of the IndoGermanic Vowel-sounds

The Indo-Germanic vowel-system $\left(\S_{30}\right) . \quad$ a $(\$ 3 \mathrm{I})$; e $(\$ 32) ; \mathbf{i}(\$ 33) ; \quad$ o $(\$ 34) ;$ u $(\S 35) ;$ o $(\S 36) ; \bar{a}$ $(\S 37) ; \overline{\mathrm{e}}(\S 38) ; \overline{\mathrm{i}}(\S 39) ; \overline{\mathrm{o}}(\S 40) ; \overline{\mathrm{u}}(\S 4 \mathrm{I}) ;$ ai $(\S 42) ;$ ei $\left(\S_{43}\right)$; oi $\left(\S_{44}\right)$; au $\left(\S_{45}\right)$; eu $(\$ 46)$; ou $(\$ 47)$. The Indg. vocalic nasals and liquids: $\mathrm{m}(\$ 48)$; n $(\S 49) ; \mathbf{r}\left(\S_{50}\right) ; 1\left({ }_{5} \mathrm{I}\right)$.

\section{CHAPTER III}

The Prim. Germanic Vowel-system

Table of the Prim. Germanic vowel-system ( $\left.\$ 5^{2}\right)$. The change of a to $\overline{\mathbf{a}}\left(\S_{54}\right)$; the change of e to $\mathbf{i}$ and of $i$ to $\bar{i}\left(\S_{55}\right)$; the change of $i$ to e $(\S 56)$; the change of $\mathbf{u}$ to $o, \overline{\mathbf{u}}(\S 57)$. The vowel-system at the close of the Prim. Germanic period $\left(\S 5^{8}\right)$. 
The OHG. Development of the General Germanic Vowel-system in Accented Syllables $30-8$

a $(\$ \S 59-60) ;$ e $(\$ \S 6 I-5) ; \mathbf{i}(\S 66) ; 0(\S 67) ; \mathbf{u}$ $(\S 68) ; \overline{\mathrm{a}}(\S 69) ; \overline{\mathrm{x}}(\S 70) ; \overline{\mathrm{e}}(\S 7 \mathrm{I}) ; \overline{\mathrm{i}}(\S 72) ; \overline{\mathrm{o}}(\S 73) ;$ $\overline{\mathbf{u}}(\$ 74)$; ai $(\$ 75)$; au $(\S 76)$; eu (\$ 77). Table of the OHG. vowels and diphthongs with their Germanic equivalents $(\$ 78)$.

\section{CHAPTER V}

The MHG. Development of the OHG. Vowel-system in Accented Syllables. • • • • $\quad \cdot \quad \cdot \quad \cdot 39-47$

Umlaut (§ 79); short vowels (\$80); long vowels (§ 81); diphthongs : ei $(\S 82)$; ie $(\S 83)$; io $(\S 84)$; iu $(\S 85)$; ou $(\S 86)$; wo $(\S 87)$. Table of the MHG. vowels and diphthongs with their OHG. equivalents (§88).

\section{CHAPTER VI}

The NHG. Development of the MHG. Vowel-system in Accented Syllables . . . . . . . 47-66

The short vowels ( $\left.\$ 89-\mathrm{Ir}_{5}\right)$. (I) Short vowels in closed syllables:-a $(\S 9 \mathrm{r}) ; \mathrm{e}(\$ 92)$; ä (\$ 93); ë $(\S 94) ; \mathbf{i}(\S 95) ;$ o $(\$ 96) ; \mathbf{u}(\S 97) ; \ddot{o}(\S 98) ; \dot{i}\left(\$ \S 99^{-}\right.$ 102); lengthening of short vowels in closed syllables (\$§ ro3-4). (2) Short vowels in open syllables:-a (§ 106); e (ä) (§ 107); ë (§ I08); i (§ I09); o (§ rro); u $(\S \mathrm{III}) ; \ddot{o}(\S \mathrm{II2}) ; \ddot{u}(\S \mathrm{II} 3)$; short vowels in open syllables followed by suffixal $\cdot e l, \cdot e n, \cdot e r(\$$ II 4$)$; short vowels in open syllables followed by $\mathbf{t}\left(\S \mathrm{Ir}_{5}\right)$. Long

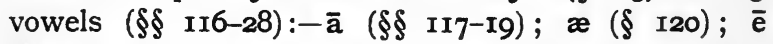
(§I2I); $\overline{\mathrm{o}}(\S \mathrm{I22}) ; \propto(\S \mathrm{I23})$; the diphthongization of $\overline{\mathbf{i}}, \overline{\mathrm{u}}$, iu (\$\$ 124-8). Diphthongs ( $\$$ I29-38): - ei (\$ 130); ou ( $(\mathrm{I} 3 \mathrm{I})$; öu (eu) ( $\S \mathrm{I32-4)}$; the monophthongization of ie, uo, uie ( $\left.\$ \mathrm{I}_{35}-8\right)$. The shortening of long vowels (\$ 139). Table of the NHG. vowels and diphthongs ( $(\mathrm{I} 40)$. 
CHAPTER VII

PAGES

The MHG. Equivalents of the NHG. Vowel-system

IN Accented Syllables. • • . . . . . 66-9

Short vowels ( $\left.\$ \mathrm{I}_{4} \mathrm{I}-8\right)$; long vowels ( $\$ \mathrm{I}_{49-56)}$; diphthongs ( $\left.\$ \mathbf{r}_{57}-60\right)$.

\section{CHAPTER VIII}

The High German Development of the Prim. Germanic Vowels of Unaccented Syllables . . 69-86 (I) The OHG. period ( $\$$ I6I-9); (2) the MHG. period ( $\$$ I70-2); (3) the NHG. period ( $\$$ I 73-84).

CHAPTER IX

AbLaUt $(\$ \S 185-8)$

\section{CHAPTER $\mathrm{X}$}

The First Sound-shifting, Verner's Law, and other Consonant Changes which took place in the Prim. Germanic Language • . . . . . . 9 91-I06

Table of the Indo-Germanic consonant-system ( 1 I9o). The normal equivalents of the Indg. explosives in Latin, Greek, and the Germanic languages ( $($ I9I). The first sound-shifting:-the tenues ( $\$ 192)$; the mediae ( $\S 193)$; the tenues aspiratae ( $(194)$; the mediae aspiratae ( $\left.\$ \S 195^{-6}\right)$. The chronological order of the first sound-shifting ( $\$$ 197). The twofold development of the Indg. velars in the Germanic languages ( $\$ 198)$. Verner's Law ( $\S$ I99). Other consonant changes ( $\$$ 200-9). Table of Prim. Germanic consonants ( $\$ 2$ I0). 
CHAPTER XI

PAGES

Special West Germanic Modifications of the General Germanic Consonant-system. The High German Sound-SHífting, \&C.

Prim. Germanic z (§ 2II). Prim. Germanic đ (\$2I2). The doubling of consonants ( $\left.\$ 2^{2} 3^{-15}\right)$. The High German sound-shifting:-Table of the Prim. High German explosives and spirants $(\$ 216)$; the shifting of the voiceless explosives $(\$ 217)$; the shifting of the voiced explosives and spirants ( $\$$ 218-19); table giving summary of the High German sound-shifting ( $\$ 220)$. Verner's Law in OHG. ( $\$ 221)$.

\section{CHAPTER XII}

The High German Consonants

The simplification of double consonants in $\mathrm{OHG}$. and MHG. ( $\$ 223)$. Double consonants in MHG. and NHG. (\$224). Notker's law of initial consonants ( $\$ 225)$. The interchange between the MHG. lenes b, d, g, v, s and the fortes $\mathbf{p}, \mathbf{t}, \mathbf{k}(\mathbf{c}), \mathbf{f}, \mathbf{s}$; and between medial intervocalic $\mathbf{h}$ and final $\mathrm{ch}(\$ 226)$. The $\mathrm{NHG}$. voiced explosives $(\S 227)$. The NHG. voiceless explosives (§ 228).

The semi-vowels :-w (\$ई 229-37); i(\$ई 238-43). The liquids :-1 $(\S 244) ; \mathbf{r}(\S 245)$. The nasals :- $\mathbf{m}(\S 246)$; n $(\$ \S 247-9) ; \quad \boldsymbol{y}(\oint 250)$. The labials :-p $\left(\$ \S 25^{\mathrm{I}-2}\right)$; b ( $\$ 253-7)$; f ( $\left.\$ \oint 25^{8-9}\right)$. The dentals :-t (\$\$ 260-4); d ( $\$ \oint 265-73) ; \quad p(\$ \oint 274-5)$. The gutturals :-h ( $\$ 276-$ $84) ; \quad \mathbf{k}(\$ \oint 285-9) ; \mathbf{g}(\$ \oint 290-2)$. The sibilant s $\left(\S \S 293^{-6}\right)$.

\section{CHAPTER XIII}

WORD-FORMATION

Nouns:-Simple nouns ( $(298)$; derivative nouns, and prefixes ( $(299)$. Noun suffixes :- chen $(\S 300)$; -ei ( $(301)$; -er, -ler, -ner ( $(302)$; -heit, -keit, -igkeit $(\S 303)$; -icht $(\$ 304)$; -in $(\$ 305)$; -ing, -ling $(\S 306)$; -lein $(\S 307)$; -nis $(\S 308)$; -sal, -sel (\$ 309$)$; -schaft $(\S 310)$; -tum ( $\left(3^{1} I\right)$; -ung ( $\left(3^{12}\right)$. Compound nouns $\left(\S \S 3^{1} 3^{-1} 5\right)$. 
PAGES

Adjectives:-Simple and derivative adjectives $(\$ \$ 316-$ 17). Adjectival suffixes:- - $\operatorname{bar}\left(\$ 3^{18}\right)$; $\cdot$ en, $-\operatorname{ern}\left(\$ 3^{1} 9\right)$; -haft $(\$ 320)$; -icht $(\$ 321)$; -ig $\left(\$ 3^{22}\right)$; -isch $\left(\$ 3^{23}\right)$; -lich $(\S 324)$; -los $(\S 325)$; -sam $(\S 326)$. Compound adjectives $\left(\$ 3^{28}\right)$.

Verbs:-The formation of verbs ( $\$ \$ 329-31)$. In. separable verbal prefixes:-be. $(\$ 332)$; ent. $(\$ 333)$; er. $(\$ 334)$; ge. $(\$ 335)$; miss. $(\$ 336)$; ver. $(\S 337)$; voll. $(\$ 338)$; zer. $(\$ 339)$. Verbal suffixes :- -eln, -ern $(\S 340)$; -ieren $(\S 34 \mathrm{I})$; -igen $(\S 342)$; -zen $(\S 343)$.

\section{CHAPTER XIV}

Nouns

Classification and gender of nouns ( $\$ \$ 344-6$ ). Declension of Nouns:-

A. The strong declension:-Masculine a-stems ( $\$$ 347-55); neuter a.stems ( $\$$ 356-60); masculine ja.stems ( $\$ 36 \mathrm{I}-2)$; neuter ja.stems ( $\$ 363-4)$; wastems ( $(365)$. Feminine ō-stems ( $\$ \S 366-9)$; feminine jō-stems $(\$ 370)$; feminine wō-stems $(\$ 37 \mathrm{I})$. Feminine abstract nouns in $-\overline{\mathbf{i}}(\$ 372)$. Masculine i-stems ( $\$$ 3734). Feminine i-stems ( $\$ \$ 375-7)$. u-stems ( $\$$ 378-8I).

B. The weak declension:-Masculine n-stems ( $\$ 3_{382-6)}$. Feminine n-stems ( $\left(3^{87}\right)$. Neuter n-stems ( $\left(3^{88)}\right.$.

C. Minor declensions :-Monosyllabic consonant stems ( $\$ \$ 389-93)$. Stems in $\cdot \mathbf{r}(\$ \$ 394-6)$. Stems in .nt ( $\$ 397)$. Stems in $\cdot c s$, es $(\$ 398)$.

\section{CHAPTER XV}

Adjectives - $\cdot{ }^{-}$General remarks on the declension of adjectives

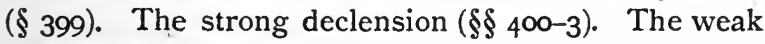
declension $(\$ 404)$. The comparison of adjectives: The comparative degree ( $\$ 4_{405-7)}$; the superlative degree ( $\$$ 408-9); irregular comparison ( $\$$ 4I0-12). Numerals: Cardinal ( $\left.\$ 4^{1} \mathrm{I}^{-2}-2 \mathrm{I}\right)$; ordinal ( $\left.\$ \oint 422-3\right)$; other numerals ( $\left.\$ 4_{424-30}\right)$. 


\section{CHAPTER XVI}

PAGES

Pronouns

General remarks on the pronouns ( $\$ 43 \mathrm{I})$. Personal pronouns ( $\$$ 432-4I). Reflexive pronouns ( $\left.\$ \$ 44^{2-4}\right)$. Possessive pronouns ( $\$$ 445-7). Demonstrative pronouns ( $\$ \$ 448-63)$. Relative pronouns $(\$ 464)$. Interrogative pronouns ( $\$ 4_{465}-8$ ). Indefinite pronouns $(\S \S 469-70)$.

\section{CHAPTER XVII}

VERBS

The classification of verbs ( $\$ \$ 47 \mathrm{I}-3)$. The full conjugation of a strong verb in OHG., MHG., and NHG. ( $\S 474)$. The endings of strong verbs ( $\$ \S 475-80$ ). General remarks on the strong verbs $(\$ \S 48 \mathrm{I}-9)$. The classification of strong verbs:-Class I ( $\$ 4_{490-2)}$; Class II ( $\$$ 493-5); Class III ( $\$$ 496-502); Class IV ( $\S 503-6)$; Class V ( $\S 507-10)$; Class VI ( $\left.\S 5^{11-2}\right)$; Class VII $(\$ \S 513-9)$. The classification of weak verbs (\$\$ 520-6). The full conjugation of legen, hören, salben, and leben in OHG., MHG., and NHG. ( $(527)$. The endings of weak verbs $(\$ \S 528-9)$. General remarks on the weak verbs ( $\$ \$ 530-3)$. Minor groups:Preterite-presents ( $\$ \S 534-40$ ). The verbs in $\cdot \mathrm{mi}$ $(\$ \S 54 \mathrm{I}-5)$. 


\section{SELECT LIST OF BOOKS USED}

von Bahder, Karl. Grundlagen des neuhochdeutschen Lautsystems. Strassburg, I8go.

Behaghel, Otto. Die deutsche Sprache. Wien und Leipzig,

I904.

Geschichte der deutschen Sprache (Paul's Grundriss der germanischen Philologie, vol. I, pp. 650-78o, Strassburg, 1897-8).

Blatz, Friedrich. Neuhochdeutsche Grammatik. Karlsruhe, 1900.

Bojunga, Klaudius Hermann. Die Entwicklung der nhd. Substantivflexion. Leipzig, 1890 .

Braune, Wilhelm. Althochdeutsche Grammatik. Halle, 1891. Brenner, Oskar. Grundzüge der geschichtlichen Grammatik der deutschen Sprache. München, 1896.

Brugmann, Karl. Kurze vergleichende Grammatik der indogermanischen Sprachen. Strassburg, 1904.

Franke, Carl. Grundzüge der Schriftsprache Luthers. Görlitz, 1888.

Grimm, Jacob. Deutsche Grammatik. Göttingen, 1822-37. Hempl, George. German Orthography and Phonology. Boston, I897.

Henry, Victor. A short Comparative Grammar of English and German. London, 1894 .

Kauffmann, Friedrich. Deutsche Grammatik. Marburg, 1902. Kluge, Friedrich. Etymologisches Wörterbuch der deutschen Sprache. Strassburg, 1894.

Nominale Stammbildungslehre der altgermanischen Dialecte. Halle, r886.

Lichtenberger, Henri. Histoire de la langue allemande. Paris, 1895 .

Michels, Victor. Mittelhochdeutsches Elementarbuch. Heidelberg, I900. 
xiv

Paul, Hermann. Deutsches Wörterbuch. Halle, I897.

Mittelhochdeutsche Grammatik. Halle, 1904.

Socin, Adolf. Schriftsprache und Dialekte im Deutschen. Heilbronn, 1888.

Streitberg, Wilhelm. Urgermanische Grammatik. Heidelberg, 1896.

Sütterlin, Ludwig. Die deutsche Sprache der Gegenwart. Leipzig, 1900.

Sweet, Henry. A History of English Sounds. Oxford, 1888. Viëtor, Wilhelm. Die Aussprache des Schriftdeutschen. Leipzig, 1905 .

Walde, Alois. Die germanischen Auslautgesetze. Halle, 1900. Weinhold, Karl. Mittelhochdeutsche Grammatik. Paderborn, 1883 .

Wilmanns, Wilhelm. Deutsche Grammatik:-Wortbildung (1896), Lautlehre (1897), Verbum (1906). Strassburg. Wright, Joseph. An Old High German Primer. Oxford, I906.

A Middle High German Primer. Oxford, 1899.

A Primer of the Gothic language. Oxford, 1899. 


\section{ABBREVIATIONS, ETC.}

Dor. $=$ Doric

EFr. = East Franconian

Fr. = Franconian

Germ. = Germanic

Goth. = Gothic

Gr. = Greek

H.Al. = High Alemanic

HG. = High German

Hom. = Homer

Indg. = Indo-Germanic

infl. = inflected

Lat. = Latin

loc. = locative

ME. . = Middle English

MFr. = Middle Franconian
MHG. = Middle High German

NE. = New English

NHG. = New High German

$\mathrm{OE} . \quad=$ Old English

OHG. = Old High German

O.Icel. = Old Icelandic

O.Ir. = Old Irish

O.Lat. = Old Latin

ON. = Old . Norse

OS. = Old Saxon

Prim. = Primitive

RFr. = Rhenish Franconian

Skr. $=$ Sanskrit

UFr. = Upper Franconian

UG. = Upper German

The asterisk * prefixed to a word denotes a theoretical form, as OHG. tag, day, from Prim. Germanic *đazaz.

In the transcription of Gothic words, ai $=$ the $\overline{\bar{x}}$ in $\mathrm{OE}$. slǣpan, to sleep, as Goth. saian, to sow; ái = the ei in NHG. stein $=$ Goth. stains $;$ ai $=$ the $e$ in NHG. herz = Goth. hairto. $a u=$ the au in English aught, as Goth. bauan, to build ; áu = the au in NHG. auge = Goth. áugo ; aú = the o in NHG. dorf = Goth. paúrp. 



\section{INTRODUCTION}

\section{GENERAL PRINCIPLES}

\$1. IN order to study the historical grammar of a language with any real profit, it is necessary for the student to possess an elementary knowledge of some of the general principles which are applicable to the historical and philological treatment of all languages. It is beyond the plan and scope of this book to do more than indicate a few of the general principles; for the rest, the student should consult books dealing specially with the subject, such as Paul's Principien der Sprachgeschichte, Sweet's Primer of Phonetics, and Passy's Petite phonétique comparée des principales langues europeennes, which contains an excellent résumé of all the student requires to know concerning phonetics.

\$2. Comparison of sound laws with physical laws.--In applying the term 'law' to the phenomena of sound-change, it is of great importance to understand that the term is used in a technical sense and must never be confounded with the use of the term 'law' as applied to the physical sciences, such as physics, chemistry, \&c. Physical laws lay down what must invariably and always happen under certain given conditions, whereas sound laws merely state the regularity of sound-change observed in any particular group of historic phenomena. At first sight this may seem to be something like a distinction without a difference, but if we examine the matter more closely we shall see that there is a material difference. Physical laws are absolute and unchanging. They operate to-day just in the 
same manner as they did in all past ages, and will continue to do so for all time to come. When we say, e.g., that the space traversed by a falling body is represented by the formula $\mathrm{S}=\frac{1}{2} \mathrm{ft}^{2}$, or that the action of sulphuric acid upon zinc is represented by the formula $\mathrm{Zn}+\mathrm{H}_{2} \mathrm{SO}_{4}=\mathrm{Zn} \mathrm{SO}$ $+\mathrm{H}_{2}$, we formulate a law which has held good and will hold good for all time and in all places. But not so with sound laws. In treating of the history and philology of any language or group of languages, two of the most important points, which the investigator carefully observes, are chronology and geography. Sound laws only operate for a limited period and then cease to operate; and their operation is often confined to a small area. It also by no means follows that a sound law which operated at one period of a language will operate again at a later period under similar conditions, e.g. in prehistoric English as also in Old Saxon and Old Frisian there operated the law whereby $\mathbf{n}$ became absorbed and the preceding vowel lengthened in the combination $\mathbf{n}+$ voiceless spirant, as OE. mūp, mouth, gōs, goose, fiff, five = OHG. mund, gans, finf. But when $\mathbf{n}$ came to stand in this position at a later period, it has regularly remained, cp. month, tenth, dense, \&c.; Indo-Germanic $\overline{\mathbf{a}}$ became $\overline{\mathbf{o}}(\S \mathbf{3 7})$ and o became $\mathbf{a}(\S \mathbf{3 4})$ in prim. Germanic, but the $\overline{\mathbf{a}}$ from older $\overline{\bar{\nexists}}(\S \mathbf{7 0})$, and the 0 from older $\mathbf{u}(\$ 57)$ which arose in prehistoric High German, remained unchanged in Old High German. Or to take another well-known sound law which concerns all the Germanic languages:-The final Indo-Germanic explosives disappeared in the primitive Germanic language, as Gothic ura = Latin quod, Goth. wili = Lat. velit, but when the Germanic explosives which arose from the Indg. mediae (\$193) and mediae aspiratae ( $(105)$ came to stand finally at a later period, they regularly remained, as $\mathrm{OE}$. dēop, deep, hlūd, loud, ǣt, he ate, lomb, lamb, \&c.

We will now pass on to the second point which we have 
already mentioned, viz. geography: the operation of a sound law is often confined to a small area. A good example of this is seen in the treatment of the Indg. ending of the accusative plural of 0 -stems in the various old Greek dialects. The original ending of this case was ons = Ionic, Attic and late Doric -ovs, Bœotian and old Doric - $\omega s$, Lesbian -oเs, Elean -oıp, Cretan -ovs and -os. Or to come nearer home, where our own dialects furnish abundant instances, let us take for example the development of Old English long $\overline{\mathbf{u}}$ (mūs, mouse) in the various modern dialects, where it has assumed eleven distinct forms (ai, au, aə, $\bar{a}$, $\overline{\mathfrak{x}}, \mathbf{e u}, \mathbf{o u}, \overline{\mathfrak{u}}, \mathbf{e u}$, əu, əui). Other examples of the great diversity of forms arising from a single $O E$. form are: OE. hām, home and fæder, father, each of which has been developed to over thirty different forms in the modern dialects. Most of the so-called irregularities in the phonology of NHG. are due to forms from the different dialects having found their way into the literary language. Many such examples will be found in the paragraphs dealing with the historical development of the NHG. vowels and consonants.

§ 3. Apart from certain cases of metathesis, dissimilation and assimilation of two sounds not standing contiguous in the same word, all sound changes take place gradually and not by sudden leaps. Such a change, for example, as that of MHG. $\overline{\mathbf{i}}, \overline{\mathrm{u}}, \overline{\mathrm{u}}$ (written iu) to NHG. ai (written ei), au, oi (written äu, eu) presupposes a rather large number of intermediate stages.

§. What is meant by saying that the laws of sound change admit of no exceptions is : that within the limits of any definite language or dialect at a particular period all sounds, which practically fulfil the same phonetic conditions, have had the same fate; that is to say, the same sound must there have changed into the same other sound throughout the language or dialect. And where various

B 2 
sounds are seen to replace one and the same other sound of the older language, the cause for this difference must be sought in the difference of phonetic conditions, such as accent, contact with or proximity to other sounds; or in other causes, such as the influences of analogy ; borrowings from another language or dialect, as NHG. sanft beside sacht; NE. hale beside whole. An example of the variation of change caused by difference of accent is the formation of doublets, one being the accented and the other the unaccented form. And what usually takes place when such doublets are called into existence through a difference of accent is that for a time they exist side by side without any difference in meaning; then one of two things takes place: either they differentiate in meaning or else one of the forms dies out and the remaining form becomes used again, both in an accented and unaccented position, as OHG. zuo beside za would have become NHG. zu beside *ze ; OHG. dū beside du would have become *dau beside du, but in NHG. only $\mathbf{z u}$ and du have been preserved. Cp. also such pairs as NE. too-to, off-of, one-an, (a), nought-not, NHG. wann-wenn, dann--denn, French moi--me, le mien -mon, \&c. Other examples of variation of change caused by difference of accent are Verner's Law ( $\$ 199)$; the development of $\bar{o}$ to uo in accented syllables in OHG., but its retention in unaccented syllables, as OHG. suochen (Goth. sōkjan) to seek, but salbōn (Goth. salbōn), to anoint.

Examples of variation of change caused by contact with or proximity to other sounds are: the threefold development of the Indg. velar gutturals in Greek (\$191 (7)), the mutation of consonants in the Keltic languages, sandhi in Sanskrit, umlaut in the Germanic languages, vowel breaking in $\mathrm{OE}$., \&c.

From what has been said above, it naturally follows that sound changes are of a twofold nature : isolative and com- 
binative. And we define isolative changes as being those which affect a sound without any reference to its surroundings, and combinative changes those which imply two sounds in juxtaposition, which modify each other in various ways.

$\S 5$. The rigid adherence to the general principle that sound laws admit of no exceptions has resulted in showing that many sound changes, which were formerly thought to be impossible, are possible, and that many, which were thought to be possible, are impossible. Many etymologies, which were formerly universally accepted, are now rightly rejected, and many others, which a generation ago would have been regarded as impossible, are now firmly established. We have only space for a few etymologies of each type. Etymologists used to regard the following pairs of words as being related, but we now know that they are not related : Lat. deus-Gr. $\theta$ cós, deer-Gr. $\theta \eta^{\prime} \rho$, whole-Gr.

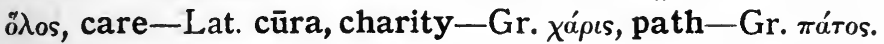
On the other hand, the following can be shown to be related: Lat. decem-centum, come-Lat. venio-Gr. $\beta a i v \omega$, cow -beef, get-Lat. pre-hendo-Gr. $\chi^{a v \delta a ́ v \omega, ~ s n o w-a c c . ~}$ Lat. nivem-Gr. vípa.

\section{CLASSIFICATION OF THE INDO-GERMANIC LANGUAGES}

§6. The High German language is a member of the West Germanic division of the Germanic (Teutonic) branch of the Indo-Germanic family of languages. This great family of languages is usually divided into eight branches:-

I. Aryan, consisting of : (I) The Indian group, including the language of the Vedas, classical Sanskrit, and the Prākrit dialects. (2) The Iranian group, including $(a)$ West Iranian (Old Persian, the language of the Persian cuneiform 
inscriptions, dating from about $520-35^{\circ}$ B.c.); (b) East Iranian (Avesta-sometimes called Zend-Avesta, Zend, and Old Bactrian - the language of the Avesta, the sacred books of the Zoroastrians).

II. Armenian, the oldest monuments of which belong to the fifth century A.D.

III. Greek, with its numerous dialects.

IV. Albanian, the language of ancient Illyria. The oldest monuments belong to the seventeenth century.

V. Italic, consisting of Latin and the Umbrian-Samnitic dialects. From the popular form of Latin are descended the Romance languages: Portuguese, Spanish, Catalanian, Provençal, French, Italian, Raetoromanic, Roumanian or Wallachian.

VI. Keltic, consisting of: (I) Gaulish (known to us by Keltic names and words quoted by Latin and Greek authors, and inscriptions on coins); (2) Brittanic, including Cymric or Welsh, Cornish, and Bas Breton or Armorican (the oldest records of Cymric and Bas Breton date back to the eighth or ninth century); (3) Gaelic, including IrishGaelic, Scotch-Gaelic, and Manx. The oldest monuments are the old Gaelic ogam inscriptions which probably date as far back as about 500 A.D.

VII. Baltic-Slavonic, consisting of: (I) The Baltic division, embracing (a) Old Prussian, which became extinct in the seventeenth century, $(b)$ Lithuanian, ( $c$ ) Lettic (the oldest records of Lithuanian and Lettic belong to the sixteenth century); (2) the Slavonic division, embracing: (a) the South-Eastern group, including Russian (Great Russian, White Russian, and Little Russian), Bulgarian, and Illyrian (Servian, Croatian, Slovenian); (b) the Western group, including Czech (Bohemian), Sorabian (Wendish), Polish and Polabian.

VIII. Germanic, consisting of:-

(I) Gothic. Almost the only source of our knowledge 
of the Gothic language is the fragments of the biblical translation made in the fourth century by Ulfilas, the Bishop of the West Goths.

(2) Old Norse (Scandinavian), which is sub-divided into two groups: (a) East Norse, including Swedish, Gutnish, and Danish; $(b)$ West Norse, including Norwegian, and Icelandic.

The oldest records of this branch are the runic inscriptions, some of which date as far back as the third or fourth century.

(3) West Germanic, which is composed of:-

(a) English, the oldest records of which belong to about the end of the seventh century. English is usually divided into three periods: Old English (OE.) up to about rrooWest Saxon, Kentish, Mercian, and Northumbrian; Middle English (ME.), II00-I500; and New English (NE.) from 1500 onwards.

(b) Frisian, the oldest records of which belong to the fourteenth century.

(c) Low German, with records dating back to the ninth century. Up to about 1200 it is generally called Old Saxon (OS.); from I200-r500 Middle Low German; and from 5500 onwards New Low German or Plattdeutsch.

(d) Low Franconian, called Old Low Franconian or Old Dutch until about I200; Middle Low Franconian or Middle Dutch from 1200 to 1500 ; from 1500 onwards New Low Franconian, including Dutch, Flemish, Brabantish, and Limburgish.

(e) High German, the oldest monuments of which belong to about the middle of the eighth century.

Notes.-(I) A few of the chief characteristics of the Germanic languages as compared with the other branches of the IndoGermanic languages are: the first sound-shifting or Grimm's Law ( $\S 192-8)$; Verner's Law ( $\$ 199)$; the development of the so-called weak declension of adjectives (\$ 399); the 
development of the preterite of weak verbs ( $\$ 531$ ); the use of the old perfect as a preterite $(\$ \mathbf{4 7 2})$.

(2) The most characteristic differences between Gothic and Old Norse on the one hand, and of West Germanic on the other, are : the West Germanic gemination of consonants ( $\$ 213$ ); the loss of final $-z$ which arose from older -s ( $\S 199,211)$; the West Germanic development of prim. Germanic ww ( $(232), j j(\S 241)$; the form of the second pers. sing. pret. indicative of strong verbs (\$ 479). Gothic and Old Norse preserved the old perfect ending, as Goth. Old Norse namt, thou tookest, but $\mathrm{OE}$. nōme, OS. OHG. nāmi. In the West Germanic languages the $-t$ was only preserved in the preterite presents, as OE. wāst, OS. wēst, OHG. weist, thou knowest.

(3) The most characteristic difference between High German and the other Germanic languages is : the High German soundshifting ( $\S 216-8)$.

$\S 7$. The division of a language into fixed periods must of necessity be more or less arbitrary. What are given as the characteristics of one period have generally had their beginnings in the previous period, and it is impossible to say with perfect accuracy when one period begins and another ends. For practical purposes High German may be conveniently divided into three periods: OHG. from about 750 to Iroo; M HG. from Iroo to 1500 ; and NHG. from 1500 onwards. 1500 to about 1650 is often called early NHG.

§ 8. OHG. may be described as the period of full endings. The most characteristic differences between OHG. and - MHG. are: the weakening of the OHG. vowels to e in unaccented syllables ( $\$ 170$ ), and the spread of umlaut (\$ 79). Some of the chief differences between MHG. and NHG. are : the spread of umlaut by analogy, especially in the plural of nouns ( $\$ \$ 350,357)$; the lengthening of short vowels which were in open syllables in MHG. (\$105); the shortening of long vowels before consonant combinations ( $\$ 139)$; the diphthongization of MHG. $\overline{\mathbf{i}}, \overline{\mathbf{u}}, \mathrm{iu}(\$ 124)$ and 
the monophthongization of ie, uo, uie ( $\$ 135)$; the substitution of the voiced explosives $b, d, g$, for the $M$ HG. lenes ( $\$ 219)$; various levellings and new formations in the indic. pres. singular of strong verbs $(\$ \mathbf{4 8 3})$; the loss of the MHG. distinction between the stem vowel of the singular and plural in the pret. indicative of strong verbs by levelling out one or other of the stem forms ( $\$ 484)$; the formation of the preterite and past participle of weak verbs direct from the present ( $\$ 531$ ).

\$ 9. The oldest records of HG. exhibit clearly defined dialectal peculiarities which have been treated in some detail in the phonology, so that the student can easily collect together for himself the chief characteristics of each dialect. The dialects are divided into three great groups: Upper German, Franconian, and East Middle German.

I. Upper German is divided into: (a) Alemanic, embracing High Alemanic (Switzerland), and Low Alemanic (South Baden, Swabia, and Alsace). (b) Bavarian, extending over Bavaria and those parts of Austria where German is spoken.

2. Franconian (West Middle German), which is subdivided into Upper Franconian and Middle Franconian. Upper Franconian consists of East Franconian (the old duchy of Francia Orientalis) and Rhenish Franconian (the old province of Francia Rhinensis), Middle Franconian extending over the district along the banks of the Moselle and of the Rhine from Coblence to Düsseldorf.

3. East Middle German, extending over: Thuringia, Upper Saxony, and Silesia. Slavonic was spoken in these parts of Germany in the Middle Ages. 


\section{PHONOLOGY}

\section{CHAPTER I}

\section{ORTHOGRAPHY AND PRONUNCIATION}

\section{The Old High German Period.}

$\S 10$. The OHG. monuments were written in the Latin alphabet. Vowel length was either entirely omitted in writing, or was represented by doubling the respective vowel; but sometimes also by using the accents ( $\left.{ }^{\prime},{ }^{\prime}\right)$. The sign -, placed over vowels, is used in this grammar to mark long vowels.

\section{A. The Vowels.}

\$11. The OHG. vowel-system was represented by the five elementary letters a, e, i, o, $\mathbf{u}$, and the digraphs ei, ie (ea, ia), io (eo), iu, ou (au), and uo (ua), the latter having the value of diphthongs. See $\$ 78$.

$\$ 12$. All the simple vowels had both a short and a long quantity. The short vowels $a, i, 0, \mathfrak{u}$, and the long vowels $\overline{\mathbf{a}}, \overline{\mathrm{e}}, \overline{\mathbf{i}}, \overline{\mathbf{o}}$, and $\overline{\mathrm{u}}$, had nearly the same pronunciation as the corresponding $\mathrm{OE}$. vowels. e had a twofold pronunciation, which is still kept apart in many NHG. dialects, according as it represented a primitive Germanic e-cp. e. g. OE.

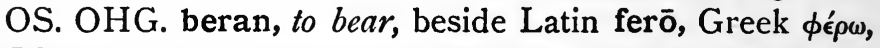
I bear-or an e which arose from the i-umlaut of a ( $\$ 60)$, as nom. sing. gast, guest, plural gesti ; nerien, to save, from *nazjan. In the former case e had an open sound like the $\mathbf{e}$ in English bed, and is generally written ë in Old and Middle High German grammars, in order to 
distinguish it from the umlaut.e, which had a close sound like the é in French été.

The following key-words will be of use, as giving an approximate pronunciation of the vowel-sounds to students unacquainted with Old English :-

\begin{tabular}{|c|c|c|c|}
\hline $\mathbf{a}$ & as in & NHG. mann & man, $\operatorname{man}$ \\
\hline$\overline{\mathbf{a}}$ & , & Engl. father & hāhan, to hang \\
\hline$\ddot{\mathrm{e}}$ & $"$ & $\mathrm{~b} e \mathrm{~d}$ & hëlfan, to help \\
\hline e & $"$ & Fr. été & gesti, guests \\
\hline$\overline{\mathrm{e}}$ & $"$ & NHG. reh & sēla, soul \\
\hline i & $"$ & Engl. it & wizzan, to know \\
\hline$\overline{\mathbf{1}}$ & $"$ & NHG. $i \mathrm{hn}$ & $\min , m y$ \\
\hline $\mathbf{o}$ & , & Engl. not & got, God \\
\hline$\overline{\mathbf{o}}$ & & NHG. so & hōh, high \\
\hline $\mathbf{u}$ & , & Engl. full & gibuntan, bound \\
\hline$\overline{\mathrm{u}}$ & $"$ & NHG. gut & hūs, house \\
\hline $\begin{array}{l}e+i \\
i+e\end{array}$ & $"$ & Engl. stain & $\begin{array}{l}\text { stein, stone } \\
\text { riet, advised. }\end{array}$ \\
\hline
\end{tabular}

The remaining diphthongs ea (ia), io (eo), iu, ou (au), uo (ua), will present no difficulties to the learner who has mastered the key-words to the short vowels in the above table. In late OHG. the diphthong iu was contracted into the long vowel $\overline{\mathrm{i}}$, although the iu was retained in writing (\$ 85).

\section{B. The Consonants.}

$\S$ 13. The OHG. consonant-system was represented by the following letters:- b, c, ch, d, f, g, h, ${ }^{*} \mathrm{j},(\mathrm{i}, \mathrm{e}, \mathrm{g}), \mathrm{k}, \mathrm{l}$, $\mathrm{m}, \mathrm{n}, \mathrm{p}, \mathrm{q}, \mathrm{r}, \mathrm{s}, \mathrm{t}, \mathrm{th}(\mathrm{dh}), \mathrm{u}(\mathrm{v}),{ }^{*} w$ (uu, u, uv, vu, vv), $\mathbf{x}, \mathbf{z}$.

The letters b, d (see $\$ 219) \mathrm{k}, 1, \mathrm{~m}, \mathrm{n}, \mathrm{p}$, and $\mathrm{t}$ had nearly the same sound-values as in English. The remaining consonants require special attention.

c had a twofold pronunciation. It had the sound of English $\mathbf{k}$ finally and before the guttural vowels a, $\mathbf{0 ,} \mathbf{u}$, 
and before consonants, as folc, folk, corn, corn, cund, known, clein, pretty. Before the palatal vowels $\mathbf{i}$, e (except in the combination sc) it had the sound of ts, like NHG. z, as lucil, little, ce, to. But, on the other hand, sceidan, to sever, where sc was pronounced like the sch in the English word school.

ch mostly represented a single (guttural spirant) sound like the ch in NHG. or in Scotch loch, as sprëchan, to speak. In Upper German monuments it was also used to express the affricata $\mathbf{k h}$, i.e. $\mathbf{k}+$ the $\mathbf{c h}$ sound in Scotch loch, as khorn (chorn), corn. See § 217, 2.

$f$ had a twofold pronunciation according as it represented a Germanic $\mathbf{f}$ or $\mathrm{p}$; cp. e.g. OHG. fater, OS. fadar, OE. fæder, father, with OHG. slāfan, OS. slāpan, OE. slæ̈pan, Goth. slēpan, to sleep. In the former case it was labio-dental, and in the latter bilabial. $\mathbf{f}=$ Germanic $\mathbf{f}$ was often written $\mathbf{u}(\mathbf{v})$ initially, and medially between vowels, as varan, OE. faran, to go ; zwival, Goth. tweifls, doubt. See $\$ 258$.

$\mathbf{g}$, when it represented prim. Germanic $\mathbf{g}$, or rather prim. Germanic $\mathbf{3}$, had the sound of English $\mathbf{g}$ in got, as OHG. guot, OE. gōd, good; OHG. tag, OS. dag, OE. dæg, day. See $\S \S 219,280$. But when it stood for prim. Germanic $j$, it was a spirant and had nearly the same sound as the $\mathbf{y}$ in English yet, as genēr (jenēr), Goth. jáins, ille, yon; herige (herie), Goth. harja, dat. sing. of heri, army.

$h$, initially and medially between vowels, had the same sound-value as NHG. $\mathbf{h}$ in hand; finally and medially before consonants it was the guttural spirant $\mathrm{ch}$ (see $\mathbf{c h}$ ), as habēn, to have, sëhan, to see; hōh (= NHG. hoch), naht (= NHG. nacht).

${ }^{*} j$ (that is $i$ in the function of a consonant) did not occur in OHG. manuscripts, but was represented by $\mathbf{i}(e, g)$. It had nearly the same sound-value as the $\mathbf{y}$ in English yet, 
as nerien from *nazjan, to save; hirteo, Goth. haírdjē, gen. pl. of hirti, shepherd; genēr (jenēr), Gothic jáins, ille, yon.

$\mathbf{q}$ occurred only in combination with $\mathbf{u}$ as in English, as OHG. quëdan, to say; quëna, woman.

$\mathbf{r}$ was a trilled sound in all positions as in Scotch, as rëht, right, bëran, to bear, fart, way, fagar, beautiful.

$\mathbf{s}$ was a voiceless spirant in all positions like the $\mathbf{s}$ in English sit, as sunu, son, kiosan, to choose, kōs, I chose.

th (dh) seems in the ninth century to have been a voiced interdental spirant like the th in English then, as thenken, to think. See $\$ 217$.

$\mathbf{u}(\mathbf{v})$. Single $\mathbf{u}(\mathbf{v})$ was often written for Germanic $\mathbf{f}$ (see f), as uaran, varan, to go. It was also employed, especially after consonants and before the vowel $\mathfrak{u}$, to express $\mathbf{u}$ consonant, i. e. English w, as suarz for suuarz, black, uurdun for uuurdun, they became.

${ }^{*} \mathbf{w}$ (i.e. $\mathbf{u}$ in the function of a consonant) did not occur in OHG. manuscripts, but was generally represented by uu (uv, vu, vv), and had the same sound-value as the $\mathbf{w}$ in English wit. It was also sometimes written $u(v)$, see above under $\mathbf{u}(\mathbf{v})$. In this grammar we shall generally write $\mathbf{w}$.

$\mathbf{x}$ occurred almost exclusively in loan-words.

$\mathbf{z}$ had a twofold pronunciation. It had the sound-value ts (= NHG. z), initially, as also medially and finally after consonants, and when it arose from older tt. Examples are:-zan, tooth, lenzo, spring, holz, wood, hërza, heart, suarz, black, scaz, money, cp. OE. sceatt, Goth. skatts; sezzen, OS. settian, to set. In other cases it was a kind of s sound, as haz, hatred, bỉzan, to bite, ëzzan, to eat. In this grammar the ts sound is represented by $z$, and the s sound by 3 . 
Phonetic Survey of the OHG. Sound-System. $\S 14$.

\section{A. Vowels.}

$$
\begin{array}{cc}
\text { Guttural } & \begin{cases}\text { Short } & \text { a, o, u } \\
\text { Long } & \overline{\mathbf{a}}, \overline{\mathrm{o}}, \overline{\mathrm{u}}\end{cases} \\
\text { Palatal } & \begin{cases}\text { Short } & \text { ë, e, i } \\
\text { Long } & \overline{\mathrm{e}} ; \overline{\mathbf{i}}\end{cases}
\end{array}
$$

\section{$\$ 15 . \quad$ B. Consonants.}

$$
\text { Labial. } \begin{gathered}
\text { Inter- Dental. Dental. } \\
\text { Gut- } \\
\text { tural. }
\end{gathered}
$$

Explosives $\begin{cases}\text { Voiceless } & \text { p, pp } \\ \text { Voiced } & \text { b, bb }\end{cases}$

$\mathrm{t}, \mathrm{tt} \quad \mathrm{k}, \mathrm{kk}$

d, dd $\quad \mathrm{g}, \mathrm{gg}$

Spirants $\left\{\begin{array}{l}\text { Voiceless f } \\ \text { Voiced }\end{array}\right.$

Nasals

$\mathrm{m}, \mathrm{mm}$

Liquids

Semi-vowels

$\mathbf{w}, \mathbf{j}$ (palatal)

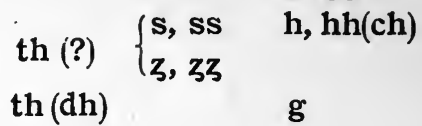

$\mathrm{n}, \mathrm{nn} \quad \mathbf{n}$

1,$11 ; \mathrm{r}, \mathrm{rr}$

To these must further be added the aspirate $\mathbf{h}$ and the three affricatae (i. e. an explosive + a homorganic spirant) z (i. e. ts), pf (ph), and the Upper German kh(ch), i. e. $\mathbf{k}+$ the ch sound in Scotch loch.

$\S 16$. A diphthong is the combination of a sonantal with a consonantal vowel. The sonantal vowel is the bearer of the stress (accent) in the syllable in which it occurs. All the OHG. diphthongs, ei, ie (ea, ia), io (eo), iu, ou (au), and uo (ua), were falling diphthongs, that is, the stress fell upon the first of the two elements.

$\S 17$. The double consonants, nn, tt, \&c., must be pronounced long as in Italian and Swedish, thus rinnan, to run, as rin-nan. They were uniformly shortened (simplified) when they became final or came to stand before other consonants, and also frequently medially when preceded by a long vowel, as rinnan, to run, pret. singular ran; bren. 
nen, to burn, pret. singular branta ; slāfan beside slāffan, to sleep. See $\$ 223$. In NHG. double consonants are never long, they merely indicate that the preceding vowel is short, as brennen, bitten, \&c.

\section{The Middle High German Period.}

\section{A. The Vowels.}

$\S 18$. MHG. had the following simple vowels and diphthongs :-

Short vowels a, ä, ë, e, i, o, u, ö, ü.

Long vowels $\overline{\mathbf{a}}, \mathfrak{x}, \overline{\mathrm{e}}, \overline{\mathrm{i}}, \overline{\mathbf{o}}, \overline{\mathrm{u}}, œ, \mathrm{iu}$.

Diphthongs ei, ie, ou, uo, öu (eu), uie.

Of the above vowels and diphthongs a, ë, e, i, o, u ; $\overline{\mathbf{a}}, \overline{\mathrm{e}}$, $\overline{\mathbf{i}}, \overline{\mathbf{o}}, \overline{\mathbf{u}}$; ei, ie, ou, and uo had the same sound-values as in OHG. The remaining vowels and diphthongs : ä, ö, $\ddot{u}$;

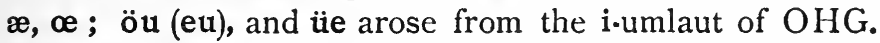
a (before those consonant combinations which prevented umlaut from taking place in OHG., $\S 60$ ), o, u ; $\overline{\mathbf{a}}, \overline{\mathrm{o}}$; ou, and uo. See $\S \mathbf{7 9}$. MHG. iu $(=\overrightarrow{\mathbf{u}})$ partly represented the OHG. diphthong iu (as biutit = M HG. biutet, he offers, \$ 85) and partly the umlaut of $\overline{\mathrm{u}}$ (OHG. hūsir, MHG. hiuser, houses, § 79). The fact that the umlant of $\overline{\mathbf{u}}$ was written iu in MHG. shows that the old diphthong had already become $\overline{\mathbf{u}}$ in late OHG., although the iu was retained in writing. MHG. ä and æ were very open e-sounds, the former like the $\mathbf{a}$ in standard English man, and the latter like the ai in English air.

The following key-words will serve to illustrate the MHG. vowel-sounds which did not occur in OHG. :-

\begin{tabular}{|c|c|c|}
\hline$\ddot{a}$ as & Engl. $\operatorname{man}$ & mähte (pl.), powers \\
\hline 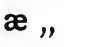 & air & lære, empty \\
\hline & NHG. löcher & löcher, holes \\
\hline $\begin{array}{l}\text { œ, } \\
\ddot{\mathbf{u}},,\end{array}$ & $\begin{array}{ll}" & \text { schön } \\
, & \text { füllen }\end{array}$ & $\begin{array}{l}\text { schœne, beautiful } \\
\text { vüllen, to fill }\end{array}$ \\
\hline
\end{tabular}


iu as in NHG. mïde

$$
\begin{aligned}
\ddot{o} \mathfrak{u}(\mathrm{eu}) & =\ddot{o} \text { or } \mathbf{e}+\mathbf{u} \\
\mathfrak{u} \mathrm{e} & =\ddot{\mathfrak{u}}+\mathbf{e}
\end{aligned}
$$

$\left\{\begin{array}{l}\text { hiuser, houses } \\ \text { biutet, he offers }\end{array}\right.$ $\left\{\begin{array}{l}\text { dröuwen, to threaten } \\ \text { dreuwen }\end{array}\right.$ grüezen, to greet

To the above list should be added the MHG. e in unaccented syllables, which mostly arose from the weakening of the OHG. full vowels, as OHG. zunga, hirti, namo, fridu = MHG. zunge, hirte, name, fride. The e in this position was pronounced like the -e in NHG. zunge, name, friede, \&c.

\section{B. The Consonants.}

$\S 19$. The MHG. consonant-system was represented by the following letters:- b, c, ch, d, f, g, h, j, k, l, m, n, p, $q, r, s, s c h, t, v, w, x, z, z$.

The letters c, ch, f, h, j, k, 1, m, n, p, pf (ph), q, r, t, w, $\mathbf{x}, \mathbf{z}, \mathbf{z}$ had the same sound-values as in OHG. The remaining consonants require special attention.

The consonants $b, d, g$ were not voiced explosives like English and NHG. b, d, g, but were voiceless lenes and only differed from the fortes $\mathbf{p}, \mathbf{t}, \mathbf{k}$ in being produced with less force ( $\$ 226)$. A similar difference existed between intervocalic $\mathbf{v}, \mathbf{s}$ and final $\mathbf{f}, \mathbf{s}(\S 226)$. In MHG., and probably also in late OHG., the lenes b, d, g, v, s regularly became the fortes $\mathbf{p}, \mathbf{t}, \mathbf{c}, \mathbf{v}, \mathbf{s}$ at the end of a word, and also medially when followed by a consonant, as gen. libes, tōdes, tages, hoves, glases beside nom. līp, life, tōt, death, tac, day, hof, court, glas, glass; gelouben, to believe, pret. geloupte, \&c. See $\S 225$.

$\mathbf{c}$ and $\mathbf{k}$ represented the same sound. The latter was generally used at the beginning, and the former at the end of a syllable, as kunst, art, trinken, to drink, pret. tranc ; senken, to sink, pret. sancte. 
\$20. Double consonants were pronounced long as in $\mathrm{OHG}$., as bit.ter, rin-nen, viul-len, \&c.

\section{The New High German Period.}

§21. A table of the NHG. vowel-system will be found in $\S 140$. It should be noted that the short vowels are open and the long vowels close. ${ }^{d^{2}} \ddot{a}$ and äu are generally used in words which have beside them obviously related forms without umlaut, as gäste, älter, bäume, häuser beside gast, alt, baum, haus $(\$ \$ 90,132)$. The historical distinction between MHG. ë, ä, and e no longer exists in the North German pronunciation of the standard language. All three sounds are pronounced as open e, like the e in English get, men, when they have remained short. When MHG. ë, ä, and e have been lengthened $(\$ 90)$ they have become close e (as in nehmen) in the language of the stage, but when written ä, as in väter, ähnlich, gebären, many people pronounce it as long open $æ$ (as in English air). This distinction is arbitrary and entirely due to the influence of the orthography. On the use of $\mathbf{h}$ in NHG. to indicate long vowels, see $\S \mathbf{2 8 0}$.

$\$ 22$. On special points connected with the pronunciation of the consonants, the student should consult $\S 227$ for b, d, g, f, s; $\S 228$ for $\mathrm{p}, \mathrm{t}, \mathrm{k}$, and $\S 245$ for $\mathrm{r}$. ch is palatal after the palatal vowels e, i, ö, $\ddot{\mathbf{u}}$, as pech, $i c h$, löcher, buicher, but guttural after the guttural vowels a, o, $\mathbf{u}$, as nach, doch, buch. Double consonants are short and merely indicate that the preceding vowel is short (\$224).

\section{Stress (Accent).}

\$23. All the Indo-Germanic languages have partly pitch (musical) and partly stress accent, but one or other of the two systems of accentuation always predominates in each language, thus in Sanskrit and Old Greek the accent was predominantly pitch, whereas in the oldest periods of 
the Italic dialects, and the Keltic and Germanic languages, the accent was predominantly stress. This difference in the system of accentuation is clearly seen in Old Greek and the old Germanic languages by the preservation of the vowels of unaccented syllables in the former and the weakening or loss of them in the latter. In the early period of the parent Indg. language, the stress accent must have been more predominant than the pitch accent, because it is only upon this assumption that we are able to account for the origin of the vowels $\stackrel{\mathrm{i}}{\mathrm{u}} \mathrm{u}, \partial$ ( $(30$, note $\mathrm{I})$, the liquid and nasal sonants ( $\$$ 48-51), and the loss of vowel often accompanied by a loss of syllable, as in Greek

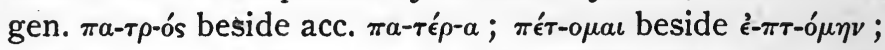
Gothic gen. pl. aúhs-nē beside acc. *aúhsa-ns. It is now a generally accepted theory that at a later period of the parent language the system of accentuation became predominantly pitch, which was preserved in Sanskrit and Old Greek, but which must have become predominantly stress again in prim. Germanic sometime prior to the operation of Verner's law ( $\$ 199$ ).

The quality of the accent in the parent language was partly 'broken' (acute) and partly 'slurred' (circumflex). This distinction in the quality of the accent was preserved in prim. Germanic in final syllables containing a long vowel, as is seen by the difference in the development of the final long vowels in historic times according as they originally had the 'broken' or 'slurred' accent $(\$ 162,3)$.

In the parent language the chief accent of a word did not always fall upon the same syllable of a word, but was free or movable as in Sanskrit and Greek, cp. e. g. Gr. nom.

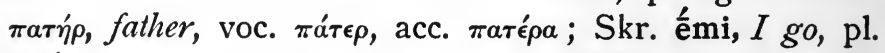
imás, we go. This free accent was still preserved in prim. Germanic at the time when Verner's law operated, whereby the voiceless spirants became voiced when the vowel immediately preceding them did not bear the chief 
accent of the word ( $\$ 199)$. At a later period of the prim. Germanic language the chief accent of a word became confined to the root- or stem-syllable. This confining of the chief accent to the root-syllable was the cause of the great weakening-and eventual loss-which the vowels underwent in unaccented syllables in the prehistoric period of the individual Germanic languages (\$ 162). And the extent to which the weakening of unaccented syllables has been carried in some of the Modern Germanic dialects is well illustrated by such sentences as, as et it moən, $I$ shall have it in the morning; ast a dunt if id kud, I should have done it if I had been able (West Yorks.).

$\S 24$. The rule for the accentuation of uncompounded words is the same in German as in the other Germanic languages, viz. the chief stress falls upon the stem-syllable and always remains there even when suffixes and inflexional endings follow it. This syllable is always the first of the word. The position of the secondary stress in trisyllabic and polysyllabic words fluctuated in OHG. and MHG. just as it does in NHG. In words containing such suffixes as -bar, -in(n), -ing (-ling), -lein, -lich, -nis, -sal, -sam, -ung, \&c., the suffix must have had the secondary stress in MHG. as in NHG., which accounts for the preservation of the full vowel.

NoтE.-In a few words the chief stress has been shifted from the first to the second syllable in NHG., as forelle (MHG. fórhel, fórelle), hornisse (MHG. hórniz), holunder (MHG. hó. lunder), lebendig (MHG. lébendic), wacholder (MHG. wáchalter), massholder (MHG. mázolter), schmarotzen older schmarutzen. The change of stress is probably due to their having been mistaken for foreign or compound words. Similarly in hermelin (MHG. hérmelinn).

$\S 25$. In compound words it is necessary to distinguish between compounds whose second element is a noun or an adjective, and those whose second element is a verb. In the 
former case the first element had the chief accent in the parent Indg. language; in the latter case the first element had or had not the chief accent according to the position of the verb in the sentence. But already in prim. Germanic the second element of compound verbs nearly always had the chief accent ; a change which was mostly brought about by the compound and simple verb existing side by side. In all periods of the German language it has been the rule for the chief accent to fall upon the second element of compound verbs, when the first element was inseparable, and for the chief accent to fall upon the first element when it was separable. Verbs like antworten, herbergen, massregeln, urteilen, \&c., are no exception to the rule, because all such verbs have been formed direct from nouns, cp. urteil beside erteilen.

$\S 26$. As has been stated above, compound words whose second element is a noun or an adjective had originally the chief accent on the first syllable. This simple rule has in a great measure been preserved in German, as antwort, berspiel, etgenhändig, grossmütig, imbiss, missbrauch, missgestalt, rückkehr, urlaub, vollmacht, vollständig, schreibtisch, \&c. Words like entgelt, entsprechung, ertrag, misshandlung, übersetzung, unterhaltung, unterhaltsam, verlust, verstand, vollendung, \&c., with the chief accent on the second element, are no exception to the rule, because all such words have been formed direct from the corresponding verbs : entgelten, entsprechen, ertragen, \&c.

Already in OHG. and MHG. many nouns were formed from verbs containing an inseparable particle, and accordingly had the chief accent on the second element. The same rule also holds good for similar nouns and adjectives in NHG. In like manner the prefix ge-(OHG. gi-) was already unaccented in the oldest period of the languageprobably partly also in prim. Germanic-and therefore nouns compounded with it have the chief accent on the 
second element in NHG., as gebäude, gebirge, gebot, geduld, gesicht, getreide, gewalt, \&c.

In compound nouns the first element of which is used attributively, the accent varies according as the first or the second element of the compound is the more important, as gróssmutter, juingfrau, but viertelstuinde, nordwést, südwést, \&c. This difference also existed in OHG.

The chief accent has been shifted in a large number of compound adjectives, and adjectives derived from compounds, especially when they end in -ig and -lich, as allmächtig, alltäglich, ausführlich, barmherzig, eigentümlich, freiwillig, vortrefflich, vorzüglich, wahrhaftig, wahrscheinlich, \&c., whence nouns formed from such adjectives also have the chief accent on the second element, as barmherzigkeit, wahrhaftigkeit, wahrscheinlichkeit.

Many adjectives have a fluctuating accent according to their position in the sentence, as zweiundzwanzig, but zweiundzwanzig mann; er ist blutjing, but or ist ein blutjunger mensch; and similarly with bettelarm, hochfein, stockblind, taubstumm, wildfremd, \&c. In a few adjectives the meaning varies according as the chief accent is on the first or second element, as blutarm, steinreich, unhaltbar.

In adjectives compounded with un- the first element generally has the chief accent, when there is a corresponding positive adjective in common use, as unecht, unfreundlich, unfruchtbar, ungchorsam, ungnädig, unklar, unlieb, unrecht, \&c. ; but adjectives, with un-, derived from verbs and generally ending in -bar, -lich, and often in -haft, -ig, -sam, usually have the chief accent on the stem-syllable, as unaufhörlich, unaufhaltsam, unbegreiflich, unberechenbar, undenkbar, unendlich, unentgeltlich, unerträglich, unmöglich, unsäglich, unstreitig, unzählig, unzweifelhaft, \&c. This distinction in the two classes of adjectives compounded with un- existed already in OHG. In the latter class of adjec- 
tives the tendency to shift the chief accent is far more common in North than in South German.

\$27. In compound adverbs the first element has the chief or secondary accent according as it is the more or less important element of the compound, as auswärts, dámals, diesseits, innerhalb, jeinseits, kréuzweise, vórmals, but allenthálben, allerdings, bergáb, sofórt, überaill.

\$28. Loan-words, borrowed at an early period, generally have the chief accent on the same syllable as they would have if they were native words, as dichten, minster, münze, ordentlich (with native suffix), Pfalz, pfropfen, \&c. But Romance words borrowed at a later period generally have the chief accent on the last syllable or on one of the last syllables, as adresse, appetit, armee, cousine, disputieren, kapelle, offizier, originell, nervös, papier. The same rule holds good with native words having foreign endings, as bäckerei, brauerei, halbieren, hofieren, \&.c.

\$29. In compounds the chief secondary accent usually falls upon that syllable of the second element which would have the chief accent if it were used alone, as gritsbesitzer, häusfràu, strässenbahnwàgen, zweiggliedrig, \&c. It should be noted that the secondary accent is generally stronger in compounds than in derivatives. But already in MHG., and probably also in late OHG., there was a tendency, in accordance with the prevailing rhythm of the language, to shift the chief secondary accent so as to have a regular alternation between strong and weak accented syllables, as in NHG. anmerkìngen, inbrauchbìr, uinvorsichtig, voorurtèil, uirgrossvàter, ìrsprǘnglich, \&c. 


\section{CHAPTER II}

THE PRIMITIVE GERMANIC EQUIVALENTS OF THE INDO-GERMANIC VOWEL-SOUNDS

§30. The parent Indo-Germanic language had the following vowel-system :-

\begin{tabular}{|c|c|}
\hline $\begin{array}{l}\text { Short vowels } \\
\text { Long " } \\
\text { Short diphthongs }\end{array}$ & $\begin{array}{l}\text { a, e, i, o, u, ə } \\
\bar{a}, \bar{e}, \bar{i}, \bar{o}, \bar{u} \\
\text { ai, ei, oi, au, eu, ov }\end{array}$ \\
\hline $\begin{array}{l}\text { Long " } \\
\text { Short vocalic }\end{array}$ & $\begin{array}{l}\text { ài, èi, ōi, āu, ēu } \\
1, \quad m, n, r\end{array}$ \\
\hline
\end{tabular}

Note.-I. The short vowels $\mathbf{i}, \mathbf{u}, \partial$, the long vowels $\overline{\mathbf{i}}, \overline{\mathbf{u}}$, and vocalic $1, \mathrm{~m}, \mathrm{n}, \mathrm{r}$ occurred originally only in syllables which did not bear the principal accent of the word.

The short vowels $\mathbf{i}, \mathbf{u}$, and vocalic $1, \mathrm{~m}, \mathrm{n}, \mathbf{r}$ arose from the loss of e in the strong forms ei, eu, el, em, en, er, which was caused by the principal accent having been shifted to some other syllable in the word.

$\partial$, the quality of which cannot be precisely defined, arose from the weakening of an original $\overline{\mathrm{a}}, \overline{\mathrm{e}}$, or $\overline{\mathrm{o}}$, caused by the loss of accent.

$\overline{\mathbf{i}}$ and $\overline{\mathbf{u}}$ were contractions of weak diphthongs which arose from the strong forms eia, āi, èi, ōi ; eua, āu, êu, ōu through the loss of accent. The e in eir, eur had disappeared before the contraction took place. See $\S 23$.

2. The long diphthongs $\overline{\mathbf{a}} \mathbf{i}, \overline{\mathrm{e}} \mathbf{i}$, \&c., were of rare occurrence in the parent language, and their history in the prehistoric period of the various branches of the Indo-Germanic languages, except when final, is still somewhat obscure. In stem syllables they were generally either shortened to ai, ei, \&c., or the second element $(\mathbf{i}, \mathbf{u})$ disappeared. In final syllables they were generally shortened to ai, ei, \&c. In this book no further account will be taken of the Indg. long diphthongs in stem syllables. For their treatment in final syllables in Primitive Germanic, see $\S 162,3$. 
3. Upon theoretical grounds it is generally assumed that the parent language contained long vocalic $1, m, n, r$. But their history in the various Indg. languages is still uncertain. In any case they were of very rare occurrence, and are therefore left out of consideration in this book.

$\S$ 31. a (Lat. a, Gr. a) remained, as Lat. ager, Gr. ảypós, Goth. akrs, OS. akkar, OHG. ackar, field, acre; Lat. aqua, Goth. ahva, OHG. aha, water; Lat. dacruma

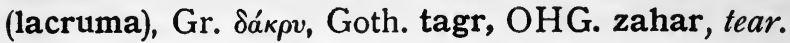

§ 32. e (Lat. e, Gr. є) remained, as Lat. ferō, Gr. ф'́ $\rho \omega$, $I$ bear, OHG. OS. OE. beran, to bear; Lat. edō, Gr.

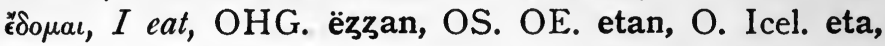
to eat; Lat. pellis, Gr. $\pi \dot{e} \lambda \lambda \alpha$, OHG. fël, OE. fell, skin, hide.

§33. i (Lat. i, Gr. ı) remained, as Gr. Hom. Fí $\hat{\mu} \mu v$, Goth. witum, OE. witon, OS. witun, OHG. wizzum, we know ; cp. Lat. vidēre, to see ; Lat. piscis, Goth. fisks, OE. fisc, OS. OHG. fisk, fish.

\$34. o (Lat. o, Gr. o) became a in stem syllables, as Lat. octō, Gr. ỏ $\kappa \dot{\omega}$, Goth. ahtáu, OS. OHG. ahto, eight ; Lat. hostis, stranger, enemy, Goth. gasts, OS. OHG. gast, guest.

§ 35. u (Lat. u, Gr. v) remained, as Gr. кvvós (gen. sing.), Goth. hunds, OE. hund, OHG. hunt, dog, hound; Gr. . $\theta \dot{v} p \bar{a}, \mathrm{OE}$. duru, OS. duri, OHG. turi, door; Lat. gustus, taste, Goth. ga-kusts, OS. OHG. kust, test, chorce.

$\$$ 36. $\partial$ became $\mathbf{a}$ in all the Indo-Germanic languages, except in the Aryan branch, where it became $\mathbf{i}$, as $\mathrm{Gr}$.

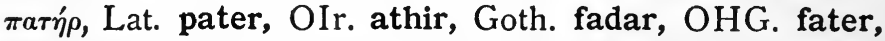
Skr. pitár. (from *pətér-), father; Gr. orarós, Lat. status, Skr. sthitás, standing, Goth. stajs, OHG. stat, place.

$\S$ 37. $\overline{\mathbf{a}}$ (Lat. $\overline{\mathbf{a}}, \mathrm{Gr}$. Doric $\bar{a}$, Attic, Ionic $\eta$ ) became $\overline{\mathbf{o}}$, as

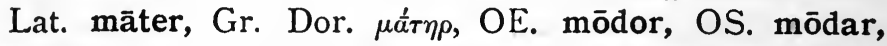

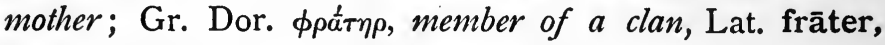
Goth. brōpar, OE. brōđor, OS. brōthar, brother; Lat. 
fāgus, beech, Gr. Dor. фāyós, a kind of oak, Goth. bōka, letter of the alphabet, $\mathrm{OE}$. bōc-trēow, beech-tree, OS. O. Icel. bōk, beech.

§38. $\overline{\mathrm{e}}$ (Lat. $\overline{\mathrm{e}}, \mathrm{Gr} . \eta$ ) remained, but it is generally written $\bar{æ}(=$ Goth. $\overline{\mathrm{e}}, \mathrm{OE} . \bar{æ}, \mathrm{OS}$. OHG. $\overline{\mathrm{a}})$ in works on Germanic philology, as Lat. ēdimus, Goth. ètum, OE. ǣton, OHG. āzum, we ate; Lat. mēnsis, Gr. $\mu \eta^{\prime}$, month, Goth. mēna, OS. OHG. māno, moon; Goth. ga.dēps, OE. dǣd, OS. dād, OHG. tāt, deed, related to Gr. $\theta \dot{\eta}-\sigma \omega, I$ shall place.

§ 39. $\overline{\mathbf{i}}$ (Lat. $\overline{\mathbf{i}}, \mathrm{Gr}$. i) remained, as Lat. su-inus (adj.), belonging to a pig, Goth. swein, OE. OS. OHG. swin, swine, pig ; Lat. simus, OHG. sìm, we may be.

$\$$ 40. $\overline{\mathbf{o}}$ (Lat. $\overline{\mathrm{o}}, \mathrm{Gr} . \omega$ ) remained, as Gr. $\pi \lambda \omega \tau$ ós, swimming, Goth. flōdus, OE. OS. flōd, flood, tide, cp. Lat. plōrāre, to weep aloud; Gr. Dor. $\pi \omega$ s, Goth. fōtus, OE. OS. fōt, foot.

§ 41. $\overline{\mathrm{u}}$ (Lat. $\overline{\mathrm{u}}, \mathrm{Gr} . \bar{v})$ remained, as Lat. mūs, Gr. $\mu \hat{v} s$, OE. OHG. mūs, mouse ; Lat. sūs, Gr. îs, OE. OHG. sū, sow, pig; Goth. fūls, OE. OHG. fül, foul, related to Gr. $\pi \dot{v} \theta \omega$, I make to rol, Lat. pūteō, I smell bad.

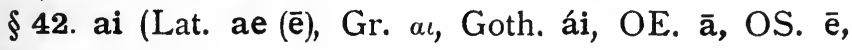

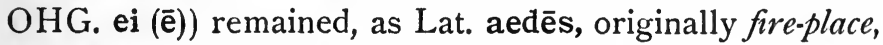
hearth, Gr. ä $\theta \omega, I$ burn, OE. ād, OHG. eit, funeral pile,

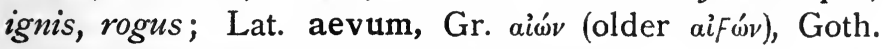
áiws, OHG. ēwa, time, life-time, eternity.

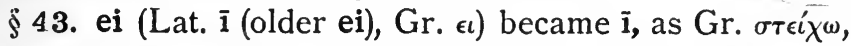
$I$ go, Goth. steigan (ei =i $),$ OE. OS. OHG. stigan, to ascend; Gr. $\lambda \epsilon i ́ m \omega, I$ leave, Goth. leihan, OHG. lihan, to lend.

§ 44. oi (O. Lat. oi (later $\overline{\mathrm{u}}$ ), Gr. o ) became ai (cp. § 34), as Gr. oỉ̇e, Goth. wáit, OE. wāt, OS. wēt, OHG. weiz, he knows; O. Lat. oinos, Goth. áins, OE. ān, OS. ēn, OHG. ein, one, cp. Gr. oiv', the one on dice.

§ 45. au (Lat. au, Gr. $a v$, Goth. áu, OE. ēa, OS. ō, OHG. ou (ō)) remained, as Lat. auris, Goth. áusō, OE. eare, OS. OHG. ōra, ear; Lat. augēre, to increase, Gr. 
av̉ ḱavo, I increase, Goth. aukan, OHG. ouhhōn, to add, increase, $\mathrm{OE}$. ēacen (pp.), increased, large.

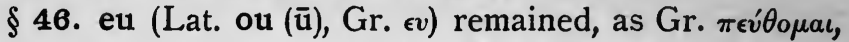
I inquire, prim. Germanic *beuđō, I inquire, offer; Gr. $\gamma \in v$ w, I give a taste of, prim. Germ. *keusō, I test, choose; Indg. *deukō, Lat. doucō (dūcō), prim. Germ. *teuxō, I lead. See $\$ 77$.

\$47. ou (Lat. ou ( $\bar{u})$, Gr. ov) became au (cp. § 34), as Indg. *roudhos, Goth. ráups, OE. rēad, OS. rōd, OHG. rōt, red; Indg. *bhe-bhoudhe, has waked, Goth. báup, OE. bēad, OS. bōd, OHG. bōt, has offered.

§ 48. m (Lat. em, Gr. $a, a \mu$ ) became um, as Gr. a $\mu o^{-}$(in $\dot{\alpha} \mu \dot{0} \theta \epsilon v$, from some place or other, $\S 191$ (8)), Goth. sums, OE. OS. OHG. sum, some one; Gr. éкaróv, Lat. centum (with $\mathbf{n}$ from $\mathbf{m}$ by assimilation, and similarly in the Germanic languages), Goth. OE. OS. hund, OHG. hunt, hundred, all from a prim. form *kmtóm.

\$ 49. $\mathbf{n}$ (Lat. en, Gr. a, av) became un, as Lat. commentus (pp.), invented, devised, Gr. avंó- $\mu$ aros, acting of one's own will, Goth. ga-munds, OHG. gi-munt, remembrance, prim. form *mntós (pp.) from root men-, think; OE. wundor, OS. wundar, OHG. wuntar, wonder, cp. Gr. $\dot{a} \theta \rho^{\prime} \epsilon$ (from * $\left.F a \theta \rho \rho^{\prime} \omega\right)$, I gaze at.

\$ 50. $\mathbf{r}$ (Lat. or, Gr. $\alpha \rho, \rho a$ ) became ur, ru, as OE. durron,

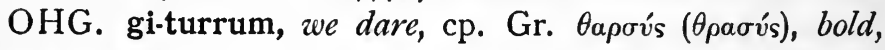

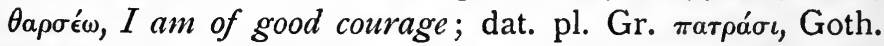
fadrum, OE. fæd(e)rum, to fathers; Lat. porca, the ridge between two furrows, OE. furh, OHS. furuh, furrow.

$\S 51.1$ (Lat. o1, Gr. $a \lambda, \lambda \alpha$ ) became u1, $1 \mathrm{u}$, as Goth. fulls, OE. OS. full, OHG. vol, prim. form *plnós, full; Goth. wulfs, OE. OS. wulf, OHG. wolf, prim. form *wlqos, wolf.

Note.-The $\mathfrak{u}$ in $\mathbf{u m}, \mathbf{u n}, \mathbf{u r}, \mathbf{r u}, \mathfrak{u l}, \mathbf{l u}$ had the same further development in the Germanic languages as Indo-Germanic $\mathbf{u}$. See $§ 57$. 


\section{CHAPTER III}

\section{THE PRIMITIVE GERMANIC VOWEL-SYSTEM}

§52. From what has been said in $\$ \S 31-51$, we arrive at the following vowel-system for the prim. Germanic language :-

$\begin{array}{ll}\text { Short vowels } & \text { a, e, i, } \mathbf{u} \\ \text { Long " } & \overline{\bar{x}}, \overline{\mathrm{e}}, \overline{\mathbf{1}}, \overline{\mathbf{o}}, \overline{\mathbf{u}} \\ \text { Diphthongs } & \text { ai, au, eu }\end{array}$

Note. $-\overline{\dddot{x}}$ was an open e-sound like OE. $\bar{æ} . \quad \overline{\mathrm{e}}$ had the sound of the $\overline{\mathrm{e}}$ in NHG. reh. The origin of this vowel has not yet been satisfactorily explained. It is important to remember that it is never the equivalent of Indo-Germanic $\bar{e}(\S 38)$ which appears as $\bar{æ}$ in prim. Germanic. See $\S \S 70-1$.

$\S 53$. This system underwent several modifications during the prim. Germanic period, i. e. before the parent language became differentiated into the various separate Germanic languages. The most important of these changes were :-

§54. $\mathbf{a}+\mathrm{y}_{\mathrm{X}}$ became $\overline{\mathbf{a}} \mathrm{X}$, as Goth. OS. OHG. fāhan, from "fayxanan, to catch, seize, cp. Lat. pangō, I fasten; Goth. pāhta (inf. pagkjan), OS. thāhta (inf. thenkian), OHG. dāhta (inf. denken), OE. đōhte, from older * payxta, he thought, cp. O. Lat. tongeō, I know. Every prim. Germanic $\overline{\mathbf{a}}$ in accented syllables was of this origin. $C_{p}$. $\S 37$.

Note.-The $\bar{a}$ in the above and similar examples was still a nasalized vowel in prim. Germanic, as is seen by its development to $\bar{o}$ in OE. The $\overline{\mathbf{i}}(\S 55)$ and $\overline{\mathbf{u}}(\S 57)$ were also nasalized vowels in prim. Germanic.

\$55. e became $\mathbf{i}$ under the following circumstances:-

I. Before a nasal + consonant, as Goth. OE. OS. bindan, 
OHG. bintan, to bind, cp. Lat. of.fendimentum, chincloth, of-fendix, knot, band, Gr. $\pi \in v \theta \epsilon$ ós, father-in-law ; Lat. ventus, Goth. winds, OE. OS. wind, OHG. wint, wind; Gr. $\pi \epsilon \in \tau \epsilon$, Goth. fimf, OHG. fimf, finf, five. This explains why OHG. bintan, to bind, and hëlfan, to help, belong to the same ablaut-series. See $\$ 186$.

This $\mathbf{i}$ became $\overline{\mathbf{i}}$ under the same conditions as those by which a became $\overline{\mathbf{a}}(\S 54)$, as Goth. peihan, OS. thīhan, OHG. dihan, from "piyxanan, older * peyxanan, to thrive.

2. When followed by an $\mathbf{i}, \overline{\mathbf{i}}$, or $\mathbf{j}$ in the same or the next syllable, as Goth. preis, OE. Jrī, OHG. drī from *priies, older *treies, Gr. rрєî, three; Goth. OS. OHG. ist from *isti, older *esti, Gr. єै $\sigma \tau \iota$, is ; OHG. irdin, earthen, beside ërda, earth; OHG. ubir, over, from an original form *uperi ; Goth. midjis, OS. middi, OHG. mitti, Lat. medius, from an original form ${ }^{*}$ medhjos, middle; OS. birid, OHG. birit, he bears, from an original form *bhéreti, through the intermediate stages *béređi, "bériđi, *Bíriđi, beside inf. beran; OS. sittian, OHG. sizzen, from an original form *sedjonom, to sit.

This sound-law accounts for the difference in the stemvowels of such pairs as NHG. berg: gebirge (OHG. gibirgi); erde : irdisch (OHG. irdisc); feld : gefilde (OHG. gifildi); geben : gift ; herde (OHG. hërta) : hirt (OHG. hirti) ; recht : richten, gericht (OHG. girihti) ; wetter : gewitter (OHG. giwitiri); helfen : hilfst, hilft (OHG. hilfis, hilfit) ; geben : gibst, gibt (OHG. gibis, gibit), and similarly in the second and third person sing. of the present indic. of many other strong verbs.

3. In unaccented syllables, except in the combination .er when not followed by an $\mathbf{i}$ in the next syllable, as $\mathrm{OE}$. fēt, older fōt, from * fōtiz, older * fōtez, feet, cp. Lat. pedes, Gr. $\pi$ ó $\delta$ s. Indg. e remained in unaccented syllables in the combination er when not followed by an $\mathbf{i}$ in the next syllable, as acc. OE. fæder, OS. fader, OHG. fater, Gr. 


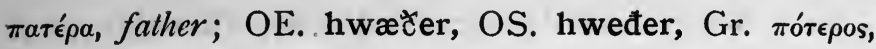
which of two.

$\S 5$. $\mathbf{i}$, followed originally by an $\check{a}, \breve{o}$, or $\bar{e}$ in the next syllable, became e when not protected by a nasal + consonant or an intervening $\mathbf{i}$ or $\mathbf{j}$, as OE. OS. OHG. wer, Lat. vir, from an original form "wiros, man; OE. OHG. nest, Lat. nïdus, from *nizdos, nest. In historic times, however, this law has a great number of exceptions owing to the separate languages having levelled out in various directions, cp. e. g. OHG. klëb beside OE. clif, rock, cliff; OHG. quëc beside OE. cwic, quick, alive, cp. Lat. vivos (vivvus); OHG. lëbara beside OE. lifer, liver; OHG. lëbēn beside OE. libban, to live; OHG. lëccōn beside OE. lic. cian, to lick; OHG. wëhha beside OS. wika, week; OHG. lërnēn beside lirnēn, to learn; OHG. wëssa beside wissa, he knew.

§57. u, followed originally by an $\breve{a}, \breve{o}$, or $\bar{e}$ in the next syllable, became $o$ when not protected by a nasal +consonant or an intervening $\mathbf{i}$ or $\mathbf{j}$, as OE. dohtor, OS. dohter,

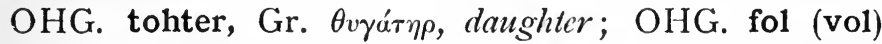
from an original form *plnós ( $\$ \mathbf{5 1})$, full, beside OHG. fulli, fullness; OE. OS. god, OHG. got, from an original form *ghutóm, God; OE. geoc, OHG. joh, Gr. ¿̌róv, yoke; OHG. hogēn beside huggen, OS. huggian, Goth. hugjan, to think; pp. OE. geholpen, OS. giholpan, OHG. giholfan, helped, beside pp. OE. gebunden, OS. gibundan, OHG. gibuntan, bound; pp. OE. geboden, OHG. gibotan, offered, beside pret. pl. OE. budon, OHG. butum, we offered.

Every prim. Germanic o in accented syllables was of this origin. Cp. $\S 34$.

This sound-law accounts for the difference in the stem vowels of such pairs as NHG. dorren (OHG. dorrēn): diirr (OHG. durri) ; geloben : geluibde (OHG. gilubida); gold : gulden (OHG. guldīn); hold : huld (OHG. huldī); 
knopf : knüpfen (OHG. knupfen, older ${ }^{*}$ knupjan); tor beside tür (OHG. turi); voll: fülle (OHG. fulli); vor : für (OHG. furi).

u became $\overline{\mathfrak{u}}$ under the same circumstances as those by which $\mathbf{a}$ and $\mathbf{i}$ became $\overline{\mathbf{a}}$ and $\overline{\mathbf{i}}$, as pret. third pers. sing. Goth. pūhta, OS. thūhta, OE. pūhte, OHG. dūhta, seemed, beside inf. Goth. pugkjan, OHG. dunken, to seem.

$\S 58$. From what has been said in $\$ \S 53-7$, it will be seen that the prim. Germanic vowel-system had assumed the following shape before the differentiation into dialects of the Germanic parent language :-

Short vowels a, e, i, o, u

Long " $\quad \overline{\mathrm{a}}, \bar{æ}, \overline{\mathrm{e}}, \overline{\mathbf{1}}, \overline{\mathrm{o}}, \overline{\mathrm{u}}$

Diphthongs ai, au, eu

The further development of these sounds in Old High German will be briefly discussed in the following chapter.

\section{CHAPTER IV}

THE OHG. DEVELOPMENT OF THE GENERAL GERMANIC VOWEL-SYSTEM

A. The Short Vowels of Accented Syllables.

a

§59. Germanic a generally remained unchanged in OHG., as OHG. ackar, OS. akkar, Goth. akrs, field, acre; OHG. OS. ahto, Goth. ahtau, eight; OHG. OS. OE. Goth. faran, to go ; OHG. fater, Goth. fadar, father; OHG. OS. gast, Goth. gasts, guest; OHG. tag, OS. dag, Goth. dags, day; OHG. bant, OS. OE. Goth. band, 
he bound; OHG. OS. Goth. nam, he took; OHG. gab, OS. Goth. gaf, he gave.

$\S 60$. a became e (umlaut, $\$ 79$ ) when originally followed by an $\mathbf{i}$ or $\mathbf{j}$ in the next syllable, as ferit, he goes, inf. faran; nom. pl. kelbir, calves, gesti, guests, beside nom. sing. kalb, gast; inf. nerien (Goth. nasjan), to save; brennen (Goth. brannjan), to burn; heri (Goth. harjis), army; lengi, length, beside lang, long. This i-umlaut of a did not take place in the following cases:-

I. Before ht, hs, or consonant $+\mathrm{w}$, as maht, power, $\mathrm{pl}$. mahti ; wahsit, he grows, inf. wahsan; bi-scatwen from *scatwjan, to shade.

2. In Upper German before $1+$ consonant, before $\mathrm{hh}$, ch (= Germanic k, § 217), and often before $\mathbf{r}+$ consonant, and before $\mathbf{h}$ (= Germanic $\mathbf{h}$ ), as UG. haltit beside UFr. heltit, he holds, inf. haltan; UG. altiro beside UFr. eltiro, older; UG. sachit beside UFr. sehhit, he quarrels, inf. sachan, Goth. sakan; UG. warmen beside wermen, Goth. warmjan, to warm; slahit beside slehit, he strikes, inf. OHG. Goth. slahan.

3. In words ending in -nissi, -nissa, or -lihh, as firstantnissi, understanding ; infancnissa, assumption; kraftlih, strong; tagalīh, daily.

The first traces of the i-umlaut of a are found about the middle of the eighth century. From then onwards umlaut is met with more and more frequently until in the early part of the ninth century the process was practically complete except in certain combinations named above. In the oldest monuments the umlaut of a was sometimes written ę, ae, ai, or ei, and at that period it was doubtless an open e-sound like the e in Engl. bed, but it probably became a close e-sound like the é in French été already in the early part of the ninth century. Umlaut e and Germanic ë are still kept apart in many NHG. dialects, the former being close and the latter open. 
e

§ 61. Germanic e (usually written ë in order to distinguish it from the e which arose from the i-umlaut of a) generally remained in OHG., as OHG. OS. OE. weg, way ; OHG. OS. OE. helm, helm; OHG. hëlfan, OS. OE. helpan, to help; OHG. OS. OE. stelan, to steal ; OHG. ëzzan, OS. $\mathrm{OE}$. etan, to eat.

\$ 62. Germanic e became $\mathbf{i}$ in OHG. when followed by a $\mathbf{u}$ in the next syllable, as hilfu, I help, nimu, I take, gibu, I give, beside inf. hëlfan, nëman, gëban ; OHG. sibun, OS. sebun, Lat. septem, seven; OHG. fihu, Lat. pecu, cattle; OHG. filu, OE. fela, from an original *pelu, much. This law has many exceptions due to new formations where the ë was regular, thus fëhu beside fihu is due to levelling out the oblique stem form, as gen. fëhes, dat. fëhe.

$\S 63$. On the OHG. change of $e$ to $i$ in the general Germanic combination eww (= Goth. iggw) and in the West Germanic combination eww from ewj, see $\$ 232$.

§ 64. On OHG. forms like lirnēn, to learn, wissa, I knew, skif, ship, skirm, protection, beside lërnēn, wëssa, skëf, skërm, see $\S 56$.

$\S 65$. In a few words ë became o through the influence of a preceding w, as woche (late OHG.), week, wola (adv.), well, worolt, world, beside wëcha, wëla, wëralt.

§ 66. Germanic i remained in OHG., as OHG. fisk, OS. OE. fisc, Goth. fisks, fish; OHG. wituwa, OS. widowa, OE. widewe, Goth. widuwō, widow; OHG. wizzan, OS. OE. Goth. witan, to know; OHG. bizzum, OE. biton, Goth. bitum, we bit; pp. OHG. gibizzan, OE. biten, Goth. bitans, bitten.

o

§ 67. Germanic o, which arose from an older $\mathbf{u}(\S 57)$, remained in OHG., as OHG. got, OS. OE. god, God; 
\$68-70] The OHG. Long Vowels

OHG. tohter, OS. dohtar, OE. dohtor, daughter; pp. OHG. gibotan, OS. gibodan, OE. boden, offered; pp. OHG. giholfan, OS. giholpan, OE. holpen, helped; pp. OHG. OS. giboran, OE. boren, borne; pret. OHG. worhta, OE. worhte, he worked, beside OHG. inf. wurken from older * wurkjan.

$\mathbf{u}$

§ 68. Germanic u remained in OHG., as OHG. OS. OE. sunu, Goth. sunus, son; OHG. OS. wurm, stem wurmi-, worm; OHG. huggen, OS. huggian, Goth. hugjan, to think; OHG. wullin, woollen, guldin, golden, beside wolla, wool, gold, gold; inf. wurken, from older *wurkjan, to work, beside pret. worhta ; pret. pl. OHG. butum, OS. budun, $\mathrm{OE}$. budon, Goth. budum, we offered; pret. pl. OHG. buntum, OS. bundun, OE. bundon, Goth. bundum, we bound; pp. OHG. gibuntan, OS. gibundan, OE. bunden, Goth. bundans, bound.

B. The Long Vowels of Accented Syllables.

$\overline{\mathbf{a}}$

$\S$ 69. Germanic $\bar{a}$, which arose from a (according to § 54), remained in OHG., as OHG. OS. Goth. fāhan, to catch, seize; OHG. OS. Goth. hāhan, to hang, beside OHG. pp. gihangan; pret. sing. OHG. dāhta, OS. thāhta, Goth. pāhta, I thought, beside inf. OHG. denken, Goth. pagkjan; pret. OHG. OS. Goth. brāhta, I brought, beside OHG. inf. bringan, to bring.

$\bar{æ}$

§ 70. Germanic $\bar{æ}(=$ OS. $\overline{\mathbf{a}}, \mathrm{OE} . \overline{\dddot{x}}$, Goth. $\overline{\mathrm{e}})$ became $\overline{\mathbf{a}}$ in OHG., as OHG. tāt, OS. dād, OE. dǣd, Goth. ga. dēps, deed; OHG. sāt, OS. sād, OE. sǣd, seed; OHG. rātan, OS. rādan, OE. rǣđan, to advise; OHG. bārum, $\mathrm{OE}$. bǣron, Goth. bērum, we bore; $\mathrm{OHG}$, sāzum, OS. 
sātun, OE. sǣton, Goth. sētum, we sat; OHG. lāzan, OS. 1ātan, OE. 1ǣtan, Goth. 1ētan, to let, allow ; OHG. slāfan, OS. slāpan, OE. slǣpan, Goth. slēpan, to sleep.

\section{$\overline{\mathbf{e}}$}

$\S$ 71. Germanic $\bar{e}$, which cannot be traced back phonologically to Indo-Germanic $\bar{e}$ ( $\$ \mathbf{5 2}$, note), is of obscure origin. In Gothic the two sounds fell together in $\bar{e}$, but in the other Germanic languages they were kept quite apart, thus Indg. $\overline{\mathrm{e}}=$ Goth. $\overline{\mathrm{e}}, \mathrm{OE} . \bar{x}, \mathrm{OHG}$. OS. O.Icel. $\overline{\mathrm{a}}$ (§ 38), but Germanic $\overline{\mathrm{e}}=$ Goth. OS. OE. O.Icel. $\overline{\mathrm{e}}$.

Germanic $\bar{e}$ remained in the oldest period of High German. In the eighth century ea appears beside $\bar{e}$. In the first half of the ninth century this ea became ia, ie. ie is the OHG. normal form from about the middle of the ninth century. Examples are: OHG. hiar, \&c., OS. OE. Goth. hēr, here; OHG. miata, \&c., OS. mēda, OE. mēd, pay, reward; pret. sing. of the old reduplicated verbs which have a, $\bar{a}$, ei in the present ( $\$ 513)$, as OHG. hialt, \&c., he held, inf. haltan; giang, he went, inf. gangan ; riat, \&c., OS. OE. rēd, inf. OHG. rātan, to advise; hiaz, \&c., OS. OE. hēt, inf. OHG. heizan, to call; early loan-words from Latin, as OHG. briaf, Lat. breve, note, letter; fiebar, Lat. febris, fever; spiagal, Lat. speculum, mirror ; ziagal, Lat. tẹgula, tile.

§72. Germanic $\overline{\mathbf{1}}$ remained in OHG. as also in the oldest periods of the other Germanic languages, as OHG. bizan, OS. OE. bïtan, Goth. beitan, to bite; OHG. OS. OE. sin, Goth. seins, his; OHG. OS. OE. swin, Goth. swein, pig.

$\overline{0}$

$\S 73$. Germanic $\overline{\mathbf{o}}$ had become uo in stem syllables in all the OHG. dialects by about the year goo. The diphthongization of $\overline{\mathbf{o}}$ to uo did not take place in all the dialects 
at the same time. In Upper Franconian uo appears beside $\bar{o}$ in the middle of the eighth century, and by the end of the century uo is the normal form except in South Rhenish Franconian (the dialect of Otfrid), where the intermediate stage ua occurs during the ninth century. In Alemanic oa appears beside $\bar{o}$ in the second half of the eighth century. By the end of the century oa (o) had become ua, which remained the characteristic form for this dialect in the ninth century. Bavarian retained $\bar{o}$ longer than the other dialects. In this dialect $\bar{o}$ became wo through the intermediate stage oa by the end of the ninth century. Examples are OHG. fuoz, OS. OE. föt, Goth. fōtus, foot; OHG. fluot, OS. OE. flōd, Goth. flōdus, flood, stream; OHG. fuor, OS. OE. Goth. fōr, I fared; OHG. suohhen, OS. sōkian, Goth. sōkjan, to seek; OHG. bluoian, OS. blōian, Goth. * blōjan, to bloom, blossom.

$\overline{\mathbf{u}}$

\$ 74. Germanic $\overline{\mathbf{u}}$ remained in OHG. as also in the oldest periods of the other Germanic languages, as OHG. OS. OE. hūs, house, Goth. hūs in gudhūs, temple; OHG. OS. OE. rūm, Goth. rūms, room; OHG. dūsunt, OS. thūsundig, OE. pūsend, Goth. pūsundi, thousand; OHG. lūhhan, OE. lūcan, Goth. ga.lūkan, to shut, close; OHG. dūhta, OS. thūhta, OE. pūhte, Goth. pūhta, it seemed, inf. OHG. dunken.

\section{The Diphthongs of Accented Syllables.}

ai

§ 75. Germanic ai (=OS. è, OE. ā, Goth. ái) became long close $\overline{\mathrm{e}}$ (through the intermediate stage of long open $\overline{\boldsymbol{\nexists}}$ often written ae, $e$ in the oldest OHG. monuments) before $\mathbf{r}$, old $\mathbf{h}(\$ 276), \mathbf{w}$, and when final. The contraction to a monophthong had already taken place in the early part of the eighth century. At this period it must have been an 
open $\overline{\dddot{x}}$ sound, otherwise it would have fallen together with Germanic è (\$ 52, note). Examples are: OHG. OS. èr, before, Goth. áir, soon, early; OHG. mēro, OS. mēra, OE. māra, Goth. máiza, greater; OHG. lēren, OS. lērian, Goth. 1áisjan, to teach ; OHG. èht, Goth. áihts, possession; pret. sing. OHG. OS. 1ēh, OE. 1āh, Goth. 1áilu, I lent; gen. OHG. OS. snēwes, OE. snāwes, of snow, Goth. snáiws, snow; OHG. sēla, older sēula, OS. seola, OE. sāwol, Goth. sáiwala, soul ; pret. sing. OHG. spēo, from older *spēw, OE. spāw, Goth. spáiw, inf. OHG. spiwwan, to spit; OHG. OS. wē, OE. wā, Goth. wái, woe!; OHG. sē, Goth. sái, lo, behold!

In all other cases Germanic ai had become ei towards the end of the eighth century, as OHG. heil, OS. hèl, OE. hāl, Goth. háils, hale, whole, sound; OHG. stein, OS. stēn, OE. stān, Goth. stáins, stone; pret. sing. OHG. steig, OS. stēg, OE. stāg, Goth. stáig, inf. OHG. stīgan, to ascend ; OHG. heizan, OS. hētan, OE. hātan, Goth. háitan, to name, call.

\section{au}

§ 76. Germanic au (OS. ō, OE. ēa, Goth. áu) became in $\mathrm{OHG}$. long close $\overline{0}$ (through the intermediate stages ao, $\bar{q}$ ) in the ninth century before the consonants $\mathrm{d}, \mathrm{t}, \mathrm{z}, \mathrm{s}, \mathrm{n}, \mathrm{r}, \mathbf{1}$ and old $h(\$ 276)$. The change from au to $\bar{q}$ through ao took place in the second half of the eighth century. At this period the monophthong must have been open, otherwise it would have fallen together with Germanic $\mathbf{0}$ (§ 73). Examples are: OHG. tōd, OS. dōđ, OE. dēap, Goth. dáupus, death; OHG. rōt, OS. rōd, OE. rēad, Goth. ráups, red; pret. sing. OHG. gōz, OS. gōt, OE. zēat, Goth. gáut, OHG. inf. giozan, to pour ; pret. sing. OHG. OS. kōs, OE. cēas, Goth. káus, OHG. inf. kiosan, to choose; OHG. OS. 1ōn, OE. lēan, Goth. láun, pay, reward; OHG. OS. òra, OE. ēare, Goth. áusō, ear; OHG. kōl, from Lat. caulis, stalk; OHG. OS. hōh, OE. hēah, Goth. 
háuhs, high ; pret. sing. OHG. zōh, OS. tōh, OE. tēah, Goth. táuh, OHG. inf. ziohan, to draze, lead.

Before all other consonants and when final, au became ou in OHG. about the middle of the ninth century. Examples are: OHG. ouga, OS. ōga, OE. eage, Goth. áugō, eye; OHG. houbit, OS. hōbid, OE. hēafod, Goth. háubip, head; OHG. goumen, OS. gōmian, Goth. gáum. jan, to pay attention to, heed; pret. sing. OHG. boug, OS. bōg, OE. bēag, Goth. báug, OHG. inf. biogan, to bend; pret. sing. OHG. kou, OE. cēaw, OHG. inf. kiuwan, to chere.

\section{eut}

$\S$ 77. Original eu ( $\$ 46)$ became iu in Gothic. In OS. it generally became eo (io) and in OE. èo. But it became iu in OS. and ie in OE. when originally followed by an $\mathbf{i}$ or $\mathbf{j}$ in the next syllable. In OHG. it underwent a two-fold development.

I. eu became iu already in the eighth century when originally followed by an $\mathbf{i}, \mathbf{j}$, or $\mathbf{u}$ in the next syllable, as OHG. OS. niuwi, OE. niewe, Goth. niujis, stem form niuja., older neujo., new ; OHG. liuhten, OS. liuhtian, $\mathrm{OE}$. liehtan, Goth. liuhtjan, clder ${ }^{*}$ leuhtjan, to light; OHG. kiusit, OS. kiusid, OE. ciesđ, Goth. kiusip, he chooses, tests, OHG. inf. kiosan; OHG. diutisk, vulgaris, beside diota, people; OHG. kiusu, OE. cēose, I choose.

It also appears as iu in Upper German before labials and gutturals except old $\mathrm{h}$ ( $\$ 276)$ when not originally followed by an $\mathbf{i}, \mathbf{j}$, or $\mathbf{u}$ in the next syllable, as Upper German liup, dear; tiuf, deep; siuh (OE. sēoc), sick; liugan, to lie, beside Franconian liob, tiof, sioh, liogan; UG. and Fr. lioht, light, beside liuhten, to light. A difference of pronunciation must have existed between this it and the iu which arose from eu when originally followed by an $\mathbf{i}, \mathbf{j}$, or $\mathbf{u}$ in the next syllable. In the former case the iu became io in the tenth century, and by the end of 
the century had become ie as in 2. below. Whereas in the latter case the iu remained.

2. In all other cases original eu became eo, which passed into io during the first half of the ninth century. io remained the regular form until the end of the tenth century and then became ie. Examples are: OHG. OS. lioht, OE. lēoht, Goth. liuhap, a light, cp. Gr. גevkós, light, bright; OHG. OS. kiosan, OE. cêosan, Goth. kiusan, to test, choose, cp. Gr. $\gamma \in \dot{\omega} \omega$ from older ${ }^{*} \gamma \in \dot{\sigma} \sigma \omega, I$ give a taste of.

$\S 78$. From what has been said in $\$ \$ 59-77$ it will be seen that the Germanic vowel-system assumed the following shape in the OHG. period:-

$\begin{array}{lll}\text { Short vowels a, e, ë, i, o, u } \\ \text { Long " } \bar{a}, \overline{\mathrm{e}}, \overline{\mathrm{i}}, \quad \overline{\mathrm{o}}, \overline{\mathrm{u}} \\ \text { Diphthongs } & \text { ei, } & \text { ie (ia), ou, uo } \\ & \text { io } \\ & \text { iu }\end{array}$

NotE.-In comparing OHG. forms with those of the other Germanic languages, it is important to remember that :

a, $\ddot{e}, \mathbf{o}, \mathbf{u}=$ the corresponding Germanic vowels.

$\mathbf{e}$ is the umlaut of a (gast, pl. gesti, guests, $\S 60$ ).

$\mathbf{i}=(\mathrm{I}) \mathrm{Germ}$. $\mathbf{i}(\S 66),(2)$ Germ. $\mathbf{e}$ when followed by $\mathbf{a} u$ in the next syllable in OHG. (inf. nëman, but nimu, I take, § 62).

$\overline{\mathrm{a}}=(\mathrm{I})$ Germ. $\overline{\mathrm{a}}(\S 69),(2)$ Germ. $\bar{æ}$ (slāfan, OE. slǣpan, to sleep, § 70).

$\overline{\mathrm{e}}=$ Germ. ai before $\mathbf{r}$, old $\mathbf{h}, \mathrm{w}$, and when final (mēro, Goth. máiza, greater, §75).

$\overline{\mathbf{i}}, \overline{\mathbf{u}}=$ Germ. $\overline{\mathbf{i}}, \overline{\mathbf{u}}$.

$\overline{\mathrm{o}}=$ Germ. au before d, $\mathrm{t}, \mathrm{z}, \mathrm{s}, \mathrm{n}, \mathrm{r}, 1$, and old $\mathrm{h}$ (tōd, Goth. dáupus, death, § 76).

ei = Germ. ai (weiz, Goth. wait, he knowss, § 75).

$\mathrm{ie}=$ Germ. $\overline{\mathrm{e}}$ (hier, OE. hèr, here, $\S \mathbf{7 1}$ ).

io = Germ. eu (lioht, a light, cp. Gr. Aevrós, light, bright, § 77).

$\mathrm{iu}=$ Germ. eu when originally followed by an $\mathbf{i}, \mathbf{j}$, or $\mathfrak{u}$ in the next syllable (diutisk, vulgaris, beside diota, people, § 77).

ou = Germ. au (ouga, Goth. áugō, § 76).

uo $=$ Germ. ò (fuoz, OE. fōt, foot, § 73). 


\section{CHAPTER V}

\section{THE MHG. DEVELOPMENT OF THE OHG. VOWEL-SYSTEM IN ACCENTED SYLLABLES}

\section{A. Umlaut.}

$\S 79$. By umlaut is meant the modification (palatalization) of an accented vowel through the influence of an $\mathbf{i}$ or $\mathbf{j}$ in the following syllable. The only vowel which underwent this change in OHG. was a, which became close e.

The change is first met with in OHG. monuments about the middle of the eighth century. In the ninth century the process was practically complete except when the a was followed by certain consonant combinations, see $\S 60$. Umlaut must have taken place earlier in the spoken language than it is expressed in late OHG. and early MHG. manuscripts, because the $i$ which caused the umlaut was weakened to $e$ in MHG. and $\mathbf{j}$ had disappeared except between vowels. The vowels and diphthongs which underwent umlaut in MHG. are a, o, $\mathbf{u}, \overline{\mathbf{a}}, \overline{\mathbf{o}}, \overline{\mathbf{u}}, \mathbf{o u}, \mathbf{u o}$. The umlaut of all these sounds was completed by about the year 1200 .

a > e : Examples for OHG. have already been given in §60. M HG. examples are : gast, guest, pl. geste $(\mathrm{OHG}$. gesti) ; lamp, lamb, pl. lember (OHG. lembir); inf. graben, to dig, pres. 2nd and 3 rd pers. sing. grebest, grebet, (OHG. grebis, grebit); lanc, long, beside lenge (OHG. lengī), length; brennen, Goth. brannjan, to burn; bette (OHG. betti), bed.

a $>\ddot{a}$ : From the twelfth century onwards the umlaut of a also occurs-often beside forms without umlaut-in words containing the consonant combinations which prevented umlaut from taking place in $\mathrm{OHG}_{\text {., }}$ see $\S 60$, as 
$40 \quad$ Phonology

pl. mähte (OHG. mahti), pozvers; geslähte (OHG. gislahti), race, generation; wähset (OHG. wahsit), it grows ; wärmen (OHG. warmen, older ${ }^{*}$ warmjan), to warm; Upper German älter (OHG. altiro), older; kälte (OHG. kalti), coldness; hältet (OHG. haltit), he holds; äher (OHG. ahir), ear of corn; slähet (OHG. slahit), he strikes, \&c. It also occurs in derivatives ending in -lich, -lin, as mänlich, manly; schämelich, shameful; tägelich, daily; väterlīch, fatherly; väterlīn, dim. of vater, father. It is likewise met with in MHG. words which originally had an $\mathbf{i}$ in the third syllable, the vowel of the second syllable having become $i$ by assimilation, as frävele (OHG. frafali), bold; pl. mägede (OHG. magadi), maids; pl. zähere (OHG. zahari), tears.

This ä was a very open sound, nearly like the a in English man. It is generally written ä in M HG. grammars to distinguish it from old umlaut e which was a close sound. Good MHG. poets do not rhyme Germanic ë with the umlaut e, and the distinction between the two sounds is still preserved in many NHG. dialects. In like manner the modern Bavarian and Austrian dialects still distinguish between ä and ë. In the MHG. period ä, ë, and e were kept apart in Bavarian, but in Alemanic and Middle German ä and ë seem to have fallen together in ë or possibly in ä, as the two sounds frequently rhyme with each other in good poets.

$0>\ddot{0}:$ Although $\ddot{0}$, the umlaut of $\mathbf{o}$, is common in MHG. and still commoner in NHG., yet all words containing this umlaut are really new formations due to levelling or analogy, because prim. Germanic $\mathbf{u}(\$ \mathbf{5 7})$ did not become 0 in OHG. when followed by an $\mathbf{i}$ or $\mathbf{j}$ in the next syllable.

Examples are: boc, he-goat, beside dim. böcklin (OHG. pocchilī) ; dorf, village, beside pl. dörfer ; got, God, beside götinne, goddess; hof, court, beside hövesch, courtly; loch (OHG. loh), beside pl. löcher (OHG. lohhir), holes; 
tohter, daughter, beside dim. töhterlin ; pret. subj. möhte (OHG. mohti), I might; törste (OHG. torsti), I dared.

$\mathfrak{u}>\ddot{\mathrm{u}}$ : dünne (OHG. dunni), thin; künne (OHG. kunni), race, generation; pl. süne (OHG. suni), sons ; tür (OHG. turi), door ; pret. subj. zuige (OHG. zugi), inf. ziehen, to draw.

Note.-In Upper German certain consonant combinations often prevented umlaut from taking place where it might be expected. Of these the principal are:-I. Before a liquid + con. sonant, as hulde (OHG. huldi), favour ; schuldec (OHG. sculdig), guilty ; gedultec (OHG. gidultīg), indulgent; burge (OHG. burgi), dat. of burc, city; sturbe (OHG. sturbi), pret. subj. of stër en, to die; wurfe (OHG. wurfi), pret. subj. of wërfen, to throw.

2. $\mathfrak{u}$ fluctuates with $\mathfrak{i}$ when followed by a nasal + consonant, as dunken, to seem, wunne, joy, beside duinken, wiinne. This fluctuation is especially common in the pret. subj., as bunde, sunge, beside bünde, sünge, inf. binden, to bind, singen, to sing.

3. In Upper German before $\mathbf{g g}, \mathbf{c k}, \mathbf{p f}, \mathrm{tz}$ which arose from the West Germanic gemination of consonants ( $\$ \$ 213-4)$, as brugge, bridge, mugge, midge, drucken, to press, stucke, piece, hupfen, to hop, schupfen, to push; nutze, useful, nutzen, to use, beside Middle German brücke, mücke, drücken, stuicke, hüpfen, schüpfen, nuitze, nützen.

$\bar{a}>æ$ : lære (OHG. lāri), empty; mære (OHG. māri), renowned; sæjen (OHG. sājan), to sow; pret. subj. næme (OHG. nāmi), pl. nǣmen (OHG. nāmīm), inf. nëmen, to take.

The long vowel $æ$ corresponded in quality to ä in Upper German, but in Middle German it was closer and corresponded in quality to ë.

$\overline{\mathbf{o}}>œ$ : hœher (OHG. hōhir), higher; hœhest (OHG. hōhist), highest; hœren (OHG. hōren, from older *hōrjan), to hear; schœne (OHG. scōni), beautiful.

$\overline{\mathbf{u}}>\mathbf{i u}$ : briute (OHG. brūti), brides; hiuser (OHG. hūsir), houses. 
Traces of the umlaut of $\overline{\mathrm{u}}$, written $\mathrm{iu}(=\overline{\mathrm{u}})$, occur in late OHG. monuments of the tenth century. It is common in the writings of Notker († I022), as hiute older hüti, skins, hides; chriuter older chrūtir, herbs. In other writings of the tenth to the twelfth century the umlaut of $\overline{\mathbf{u}}$ is seldom found. Umlaut did not take place in Upper German before a following $\mathrm{m}$, as rūmen from *rūmjan, to make room; sūmen from *sūmjan, to tarry; schūmen from *skūmjan, to foam.

ou> öu, often written eu, rarely oi, öi : löufel (OHG. loufil), runner; löuber (OHG. loubir), leaves.

Umlaut of ou did not take place before a following $w$, as frouwe (OHG. frouwa, prim. Germ. *frawjō.), woman; ouwe (OHG. ouwa, auwia from prim. Germ. *a(z)wjō·), meadow.

Forms like döuwen, to digest, dröuwen, to threaten, fröuwen, to rejoice, höuwe, hay, ströuwen, to strew, beside douwen, drouwen, frouwen, houwe, strouwen, were all analogical formations, see $\S \mathbf{2 3 2}$.

Umlaut did not take place in Upper German before a following labial, as erlouben, to allow, gelouben, to believe, houbet, head, koufen, to buy, troumen, to dream, toufen, to baptize, beside Middle German erlöuben, gelöuben, höubet, köufen, tröumen, töufen.

uo > üe : grüene (OHG. gruoni), green; guiete (OHG. guotī), goodness; vuieze (OHG. fuozi), feet; pret. pl. subj. viieren (OHG. fuorim), inf. varn, to fare, go; buoch, book, dim. biuechlin ; muoter, mother, dim. muieterlin.

Traces of the umlaut of wo occur in late OHG. monuments, as grüene, green, süeze, sweet.

In Middle German ie became contracted to $\overline{\mathrm{u}}$ in the twelfth century.

NotE.-In Middle German ö, $\ddot{u}$, öu, ïe were not distinguished in writing from $\mathbf{o}, \mathbf{u}$, ou, uo. In early MHG. the umlaut of a,

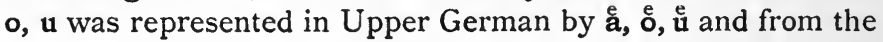


fourteenth century onwards by ä, ö, ii. å, ä do not occur in Middle German manuscripts.

\section{B. The Short Vowels.}

$\$$ 80. Apart from the changes caused by umlaut, viz. a to $\ddot{a}, o$ to $\ddot{o}$, and $\mathfrak{u}$ to $\ddot{\mathrm{i}}(\boldsymbol{\mathbf { 7 9 }})$, and the few changes treated in the notes at the end of this paragraph, the OHG. short vowels remained in MHG., as OHG. ackar, faran, fater, gast, tag, bant, nam, gab $=$ MHG. acker, varn, vater, gast, tac, bant, nam, gap.

OHG. kelbir, gesti, brennen, lengi, feris $(t)$, ferit = MHG. kelber, geste, brennen, lenge, verst, vert.

OHG. wëg, hëlfan, ëzzan, gilëgan, stëlan $=$ MHG. wëc, hëlfen, ëzzen, gelëgen, stëln.

OHG. fisk, wituwa, wizzan, bizzum, we bit, gibizzan, bitten, nimu, I take, liggen, to lie down = MHG. visch, witewe, wizzen, bizzen, gebizzen, nime, ligen.

OHG. got, tohter, gibotan, giholfan, giboran, wola, (adv.) = M HG. got, tohter, geboten, geholfen, geborn, wol.

OHG. sunu, wurm, butum, we offered, buntum, we bound, pp. gibuntan = MHG. sun, wurm, buten, bunten, gebunten.

Note.-I. In Bavarian e and ë fell together, except before liquids, in e during the MHG. period.

2. $\ddot{e}$ became close $e$ and thus fell together with umlaut $e$ before st, sch, and palatal $\mathbf{g}$, as is seen from the rhymes in the writings of the MHG. poets who in other combinations keep the two sounds apart, as gestern, nest, swester; dreschen, leschen; degen, warrior; and also in a few other words before a following 1 , as helm, schelm, vels, rock, welcher.

3. In Alemanic of the fourteenth century e (but not ë, ä) became rounded to ö especially in the neighbourhood of labials, as frömde, strange; mönsche, man; öpfel, apples. Several such forms have passed into the NHG. literary language, as ergötzen, hölle, löffel, löschen, schöpfen, schöpfer, zwölf, \&c. See § $\mathbf{9 2}$.

4. Before nasals $\mathfrak{u}$ became 0 and $\ddot{\mathfrak{u}}$ became $\ddot{o}$ in Middle 
German already in the twelfth century, as Middle German from, sonne, gönnen, könic, beside Upper German frum, sunne, günnen, künic. See $\$ \S \mathbf{9 7 , 1 0 1 .}$

5. In Middle German short vowels in open syllables began to be lengthened at the end of the twelfth century, but in Upper German traces of this lengthening are not met with until the end of the thirteenth century. See $\S 105$.

\section{The Long Vowels.}

$\$$ 81. Apart from the changes caused by umlaut, viz. $\overline{\mathbf{a}}$ to $æ, \bar{o}$ to $œ$, and $\overline{\mathrm{u}}$ to iu $(\$ 79)$, and the few changes treated in the notes at the end of this paragraph, the OHG. long vowels remained in MHG., as OHG. fāhan, to catch, slāfan, to sleep, dāhta, I thought, bārum, we bore, sāt, seed = MHG. fāhen (fān), slāfen, dāhte, bāren, sāt.

OHG. ēra, honour, lēren, to teach, mēro, greater, sēla, soul, sēo, sea $=$ MHG. ère, lēren, mēre, sēle, sē.

OHG. bizan, to bite, scriban, to write, snidan, to cut, sin, his, swìn, pig, wìb, woman = MHG. bỉzen, schriben, snīden, sīn, swīn, wīp.

OHG. bōt, I offered, kōs, I chose, hōh, high, ōra, ear, rōt, red, tōd, death = MHG. bōt, kōs, hōch, ōre, rōt, tōt.

OHG. dūhta, it seemed, sūgan, to suck, sūfan, to drink, hūs, house, rūm, room, dūsunt, thousand = MHG. dūhte, sūgen, sūfen, hūs, rūm, tūsent.

Note.-I. In Bavarian, Middle German, and a part of Alemanic $\bar{a}$ became $\bar{o}$ before a following nasal and after a preceding $w$ in the second half of the thirteenth century. See $\$ 118$.

2. Long vowels before consonant combinations began to be shortened in Middle German about the end of the twelfth century. See $\$ 139$.

3. The diphthongization of $\bar{i}, \overline{\mathfrak{u}}$, iu $(=\overline{\mathbf{u}})$ to ei, ou, eu took place in Bavarian at the end of the twelfth century, and in Swabian in the fifteenth century. In Alemanic (except Swabian) the monophthongs remained until the early NHG. period. In East Middle German the diphthongization took place in the 
early part of the fourteenth century, but in West Middle German not until the beginning of the sixteenth century. See $\S 124$.

\section{The Diphthongs.}

ei

§ 82. OHG. ei generally remained in MHG., as OHG. and MHG. bein, bone; leiten, to lead; teil, portion; OHG. screib, I wrote, sneid, I cut, heizan, to call = MHG. schreip, sneit, heizen.

ei became ai in Bavarian and Swabian in the early part of the thirteenth century. See $\$ 130$.

ie

§ 83. OHG. ie (= Germanic è, § 71) remained, as OHG. and MHG. brief, letter; fieng, I caught; gieng, I went; hielt, I held; hier, here; riet, I advised; OHG. mieta, pay, reward, MHG. miete.

ie became monophthongized to $\bar{i}$ at an early period in Middle German, and then underwent shortening to $\mathbf{i}$ before two consonants, as ging from older ging, gieng ; fing from older fīng, fieng.

§ 84. OHG. io (= Germ. eu $\S 77$ ), and OHG. io which occurs in the preterite of the old reduplicated verbs whose presents have ou, $\overline{0}$, uo ( $\$ 517-9)$, became ie already at the end of the tenth century, as OHG. liob, dear, lioht, a light, tiof, deep, biogan, to bend, biotan, to offer, kiosan, to choose, liof, I ran, stioz, I pushed, riof, I called = MHG. liep, lieht, tief, biegen, bieten, kiesen, lief, stiez, rief.

iu

§ 85. OHG. iu ( $\$ 77)$ became contracted to long $\overline{\mathrm{i}}$ about the year 100o, but the iu was retained in writing and also became used for the umlaut of $\overline{\mathrm{u}}(\S 79)$. $\overrightarrow{\mathfrak{u}}$, written $\mathbf{i u}$, remained in MHG. and fell together with iu $(=\tilde{\mathrm{i}})$, the 
i-umlaut of $\overline{\mathrm{u}}(\S 79)$, as OHG. liuhten, to light, biutit, he offers, kiusit, he chooses, liuti, people, tiuri, dear = MHG. liuhten, biutet, kiuset, liute, tiure.

\section{ou}

§ 86. Apart from the umlaut of ou to öu (eu) (\$ 79), OHG. ou remained in MHG., as OHG. boug, I bent, houbit, head, kloub, I cleft, loufan, to run, ouga, eye, ouh, also, troum, dream $=$ MHG. bouc, houbet, kloup, loufen, ouge, ouch, troum.

ou became au in Bavarian at the end of the twelfth century. See $\$ 131$.

uo

\$ 87. Apart from the umlaut of ou to uie $(\$ 79), \mathrm{OHG}$. uo remained in MHG., as OHG. bruoder, brother, fuor, I went, fluot, flood, fuoz, foot, muoter, mother, sluog, I struck, stuont, I stood, truog, I carried = MHG. bruoder, vuor, fluot, fuoz, muoter, sluoc, stuont, truoc.

In Middle German uo became contracted to $\overline{\mathbf{u}}$ in the thirteenth century. See $\$ 136$.

$\S 88$. By summing up the results of $\S \S 79-87$ it will be seen that the $\mathrm{OHG}$. vowel-system assumed the following shape in the MHG. period:-

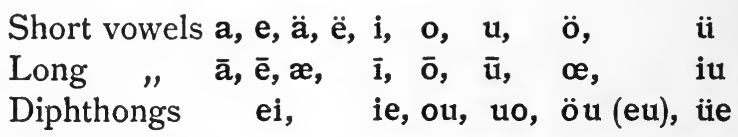

Note. - Of the above system a, e, ë, $\mathbf{i}, \mathbf{o}, \mathbf{u}=$ the corresponding OHG. vowels.

$\ddot{a}$ is the umlaut of a before certain consonant combinations which prevented umlaut from taking place in OHG., as mähte, OHG. mahti, pozvers ( $\$ \$ 60,79)$.

$\ddot{o}$ is the umlaut of OHG. o, as löcher, OHG. 1ohhir, holes ( $\$ 79)$. $i i$ is the umlaut of OHG. u, as dinne, OHG. dunni, thin (\$ 79). $\overline{\mathrm{a}}, \overline{\mathrm{e}}, \overline{\mathrm{i}}, \overline{\mathrm{o}}, \overline{\mathrm{u}}=$ the corresponding OHG. vowels.

$æ$ is the umlaut of OHG. $\bar{a}$, as lære, OHG. lāri, empty (§ 79). 
$œ$ is the umlaut of OHG. $\overline{0}$, as høher, OHG. hōhir, higher $(\S 79)$.

iu $=(\mathrm{I})$ OHG. iu, as liute, OHG. liuti, people (§ 77).

(§ 79).

(2) the umlaut of OHG. $\bar{u}$, as hiuser, OHG. hūsir, houses

ei, ou, uo $=$ the corresponding OHG. diphthongs.

ie $=(\mathrm{I})$ OHG. ie (Germanic ē), as OHG. and MHG. hier, here; hielt, I held (\$ 71).

(2) OHG. io (Germanic eu), as bieten, OHG. biotan, to offer (\$ 77).

öu (eu) is the umlaut of OHG. ou, as löuber, OHG. loubir, leaves (\$ 79).

iie is the umlaut of OHG. uo, as griiene, OHG. gruoni, green (§ 79).

\section{CHAPTER VI}

THE NHG. DEVELOPMENT OF THE MHG. VOWEL-SYSTEM IN ACCENTED SYLLABLES

A. The Short Vowels.

§ 89. The MHG. short vowels in closed syllables have generally remained in NHG., whereas the MHG. short vowels in open syllables have mostly been lengthened ( $\$ 105 \mathrm{ff}$.). When in MHG. a short vowel was now in a closed syllable and now in an open syllable through inflexional endings, NHG. has mostly generalized the form of the open syllable, as weg: wege $=$ MHG. wëc : wëge ; tag: tage $=$ MHG. tac : tage ; and similarly in the pret. of strong verbs the long vowel of the plural has been extended to the singular, as gab: gaben = MHG. gap: gāpen; nahm: nahmen = MHG. nam : nāmen. The old difference between long and short vowels in open and closed syllables has for the most part been preserved in Low German. Monosyllabic forms like bad, grab, glas, gras, rad, stab, tag, weg, steg, grob, hof, \&c., are pronounced 
long in South German, but short in North German, but in the inflected forms they are also long in North German. This explains why in the singular they are written with single final consonants.

$\S$ 90. The umlaut of $\mathbf{a}$ is now mostly written $\ddot{a}$ in NHG. in words which have beside them obviously related forms without umlaut, as gast : gäste $=$ MHG. gast : geste ; alt : älter $=$ MHG. alt : elter; lamm : lämmer $=$ M HG. lamp : lember ; tragen : trägt $=\mathrm{MHG}$. tragen : treget. $\ddot{a}$ is seldom used for the umlaut of a when no related nonumlauted forms exist beside them, but it occurs in a few words, as ähre (MHG. äher, OHG. ahir), ähnlich, mähne, mähre, träne pl. in form (MHG. trähene, OHG. trahani), zähre pl. in form (MHG. zähere, OHG. zahari). In a few words e is used where related non-umlauted forms exist, as adel: edel, bass : besser, fahrt : fertig, fast : fest, hahn: henne, hand: behende, mann: mensch. In several words ä is used for MHG. ë, as bär (MHG. bër), gebären (MHG. gebërn), see $\S 108$. In a few instances it is used to distinguish pairs of words, as ältern: eltern, färse: ferse, lärche: lerche, stärke: sterke.

The writing of à for ä was first used in Swabian. It often occurs in early works printed at Augsburg, but still more frequently in those printed at Basle, Zürich, and Bern; in the former place it was generally used for the MHG. umlaut of a and $\overline{\mathbf{a}}(\S 79)$ and in the latter places it was used for MHG. ë as well ( $\$ 80)$. e was used for all three sounds in early works printed at Nürnberg, Strassburg, and in Middle Germany. But ä came gradually to be used in these parts also. East Middle German was the last to introduce ä. It does not occur in the last edition of Luther's Bible.

The historical distinction between MHG. ä, e, and ë no longer exists in the North German pronunciation of the standard language. All three sounds are pronounced as 
open e when they have remained short. When MHG. ä, $\mathbf{e}$, and $\ddot{e}$ have been lengthened they have become close $\overline{\mathbf{e}}$ in the language of the stage, but when written ä as in ähnlich, wählen (MHG. weln), gebären, many people pronounce it as long open $\bar{æ}$. This distinction is arbitrary and entirely due to the influence of the orthography.

Rounded ö, $\ddot{u}$, and äu (eu) were not distinguished in pronunciation from unrounded $\mathbf{e}, \mathbf{i}$, ei until far into the

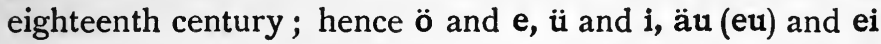
often rhyme with each other in the poetry of the eighteenth and early nineteenth centuries. The modern distinction in the pronunciation is due to Low German usage, which has gradually taken root in Modern German.

I. The Short Vowels in Closed Syllables.

§ 91. MHG. a has remained, as ab, acht, acker, an, arg, arm, bald, band, bekannt, das, fast, fand, gast, half, hand, hart, kalt, karte, scharf, schlacht, stark, tracht, warm, warten, was.

\$ 92. MHG. e, the umlaut of a, which was a close sound, has generally become open e, written e, ä in NHG., as behende, besser, brennen, denken, ende, eng, engel, ente, erbe, fertig, fest, fremd, geselle, gespenst, hemd, henne, menge, mensch, nennen, schenken, senden, senken, setzen, streng, vetter; äpfel, gäste, gedränge, hängen, kräfte, lämmer, länger, März, städte.

As we have already seen, $\S 80$, note 3 , e (but not ë, ä) became rounded to ö especially in the neighbourhood of labials in Alemanic of the fourteenth century. At a later period it occurs in the neighbourhood of $1, \mathbf{s c h}$, and in one or two other words. The change of e to ö does not seem to have spread to East Middle German, because ö for e is very rarely if ever found in Luther's writings. This ö for e occurs in NHG. in: ergötzen (MHG. ergetzen), 
erlöschen (MHG. erleschen), geschöpf, gewölbe (MHG. gewelbe), hölle (M H G. helle), löcken (M HG. lecken, to kick), löffel (OHG. leffil), löschen (M HG. leschen), schöffe (MHG. scheffe), schöpfen (MHG. schepfen), schöpfer (MHG. schepfære), schröpfen (MHG. schrepfen), wölben (MHG. welben), zzölf (MHG. zwelf). It has been lengthened to $\bar{o}$ in flötz (MHG. vletze, seam, stratum), gewöhnen (MHG. gewenen), löwe (M HG. lewe and lewe), schwören (MHG. swern).

§ 93. MHG. ä (§ 79), which was a very open sound, nearly like the low front wide vowel in Engl. man, has become the mid front wide vowel in Engl. men, and has thus fallen together with NHG. ä, e from MHG. e, ë. Examples are: älter, färben, hält (M HG. hältet, and heltet), kälber, kälte, mächte, mächtig, männlich, nächte, wärmen, wächst (MHG. wähset); eltern, geschlecht, welsch.

§ 84. MHG. ë has remained, as bergen, brechen, essen, fechten, feld, ferse, gelb, gelten, helfen, herz, melken, scherz, schmelzen, sprechen, sterben, treffen, weg (adv.); rächen (MHG. rëchen), and in dämmerung (MHG. dëmerunge with open syllable).

§ 95. MHG. i has remained, as bild, binden, bitten, finden, fisch, gewicht, gift, hin, hinter, hirsch, hirt(e), in, mild, mit, schwimmen, singen, sitzen, trinken, wild, wind, wirt, wissen.

A few words have ü for older $\mathrm{i}$, as fünf (OHG. finf, fimf); flüstern (older NHG. flistern), borrowed from Low German in the eighteenth century; münze (OHG. minza, Lat. mentha), minze is the form now prescribed in the latest books on German orthography; in hillfe beside hilfe, both forms are old and stand in ablaut relation to each other; würde (MHG. wirde), würdig (MHG. wirdic) with $\mathbf{i}$ in Luther and also common in writers of the sixteenth and seventeenth centuries; in sündflut (MHG. $\sin (\mathbf{t})$ fluot) sünd is due to association with sünde. 
$\S \S 96-100]$

\$ 96. MHG. o has remained, as bock, doch, dorf, dorn, gefochten, geholfen, gesprochen, gestorben, getroffen, geworden, gold, hold, holz, horn, joch, loch, noch, ob, tochter, voll (MHG. vol, voller), von, woche, wolf, wolke, wolle.

§ 97. MHG. u has generally remained, as brust, burg, dumm (MHG. tump, tumber), gebunden, geduld, gefunden, gesungen, frucht, hund, jung, krumm (MHG. krump, krumber), kummer (MHG. kumber), sprung, stumm, trunk, und, unter, wunde, wunsch, zunge.

In Middle German $\mathbf{u}$ became o before nasals already in the twelfth century. In NHG. $\mathbf{u}$ has regularly become $\mathbf{o}$ before $\mathrm{nn}$, frequently before $\mathrm{mm}$, and occasionally before $\mathrm{n}+$ consonant, as begonnen (MHG. begunnen), brunnen (MHG. brunne) beside the poetical form bronnen, geronnen (MHG. gerunnen), gesonnen (M HG. gesunnen), gesponnen (MHG. gespunnen), gewonnen (MHG. gewunnen), nonne (M HG. nunne), sonne (M HG. sunne), tonne (M HG. tunne), wonne (MHG. wunne); sonder (MHG. sunder), sonst (MHG. sunst, sust, sus); soln (MHG. sun) with long vowel from the gen. and dat.; geklommen (MHG. geklum. men), geschwommen (MHG. geswummen), trommel (M HG. trummel), sommer (MHG. sumer, see $\$ 114$ ), fromm (MHG. vrum, vrumer) with generalization of the unin. flected form.

§ 98. MHG. ö has remained, as pl. dörfer, löcher, töchter; göttin (MHG. göttine), pret. subj. möchte.

§ 99. MHG. $\ddot{\mathrm{i}}$ has generally remained, as brücke, bürste, dünken, dünn (MHG. dünne), dürftig, dürr, flüssig, fülle, füllen, fiurchten, fürst, gültig, gürten, gelübde originally in an open syllable (MHG. geliubede, OHG. gilubida), hülle, kürze, lücke, mücke, mürbe ( $\mathrm{MHG}$. mürwe, mür), rücken, schlüssel, zürnen; pret. subj. hülfe, stürbe, würbe, würde, wiurfe.

$\$ 100$. One of the marked differences between Middle German and Upper German in the MHG. period is that $\mathbf{u}$ 
umlaut was carried out far more extensively in the former than in the latter. This is still a characteristic difference between the modern Middle German and Upper German dialects. In $\$ \mathbf{7 9}, \mathbf{u}$, note, it has been shown that in Upper German of the MHG. period certain consonant combinations prevented umlaut from taking place where it might be expected, especially before $1 \mathrm{~d}, \mathbf{1 t}$; $\mathbf{g g}, \mathbf{c k}, \mathbf{p f}, \mathbf{t z}$, and occasionally before nasal + consonant. Several of these non-umlauted forms have passed into the NHG. literary language from the Upper German dialects, as dulden, geduldig (OHG. dultīg), gulden beside adj. gülden (OHG. guldīn), huld (OHG. huldī), kurfürst but willkür (OHG. kuri, choice), schuldig (OHG. sculdīg); kunde (MHG. künde), kundig (MHG. kündic), um (M HG. umbe, ümbe, OHG. umbi), nutze beside nütze (MHG. nütze), nutzen beside nützen; ducken, spucken, schlucken, drucken, to print, beside drücken, to press, zucken, to jerk, beside zücken, to draw (a sword); rupfen, schupfen, zupfen; stutzen.

$\S$ 101. Parallel with the change of $\mathbf{u}$ to $\mathbf{o}(\S 97)$ was that of $\ddot{i}$ to $\ddot{o}$ in Middle German of the twelfth century. Several such forms have survived in the NHG. literary language, as gönnen (MHG. günnen), können (MHG. kün. nen), mönch (MHG. münech), the pret. subj. of strong verbs, begönne (MHG. begünne), and similarly in gewönne, rönne, sönne, spönne, schwömme; with the vowel lengthened in open syllables (\$112), in könig (MHG. künec), mögen (MHG. mügen), söhne (M HG. süne), stör (MHG. stüre, störe); with lengthened vowel in börse (M HG. burse, OHG. burissa); with short vowel in röcheln (MHG. rücheln).

$\S 102$. In Bavarian, Swabian, and Middle German, there was a tendency to unround $\mathfrak{i}$ to $\mathfrak{i}$ already in the fourteenth century. iu has been regularly unrounded to $\mathbf{i}$ in many of the modern dialects from which several words containing $\mathbf{i}$ for older $i \mathrm{i}$ have passed into the literary language, as findling (MHG. fündling), gimpel (MHG. gümpel), kissen 
§§ 103-6] The NHG. Vowels

(MHG. küssen), kitt (MHG. küte, küt), pilz (M HG. bülez), schlingel beside older NHG. schlïngel, simmer (MHG. sümmer), spritzen (M HG. sprützen).

$\S 103$. Short vowels in closed syllables have regularly been lengthened before simple final $\mathbf{r}$ in monosyllables, as ar, dar, gar, der, er, her, wer, dir, ihr, mir, wir, vor, but dăran, hërein, vŏran, \&c., when the first element is unstressed ; empor, gewahr.

$\$ 104$. a and $\mathbf{e}$ (rarely other vowels) have often been lengthened in closed syllables before $\mathbf{r}+$ dental, but this lengthening is not recognized as the standard by all educated speakers. The examples are: art, arzt but ărztlich, arsch, barsch, bart, fahrt, harz, quarz, scharte, schwarte, zart; gefährte; erde, herd, herde, pferd, schwert, werden, wert; begierde, börse, geburt.

\section{The Short Vowels in Open Syllables.}

$\S 105$. Short vowels have generally been lengthened in open syllables when followed by a media, liquid, nasal, or f, $\mathbf{s}$ (=Germanic $\mathbf{f}, \mathbf{s})$. The lengthening took place earliest in Middle German where traces of it are found in monuments of the late twelfth and early thirteenth centuries. Traces of the lengthening are not met with in Upper German until about the end of the thirteenth century.

NotE.-Lengthening has not taken place before the spirants ff, ss, ch (= Germanic p, t, k, § 217), nor before ck, as offen, treffen, essen, vergessen, machen, sprechen, brïcke, decken.

\$108. a: aber, adel, baden, base, fahl, fahren, graben, haben, hader, hafer, hase, jagen, klagen, laben, laden, mahlen (to grind), name, nase, sagen, tragen, wagen (carriage); bad, bahn, glas, grab, gram, gras, hahn, kahl, lahm, rad, saal, scham, schar, schmal, schwan, stab, tag, zahl, zahm, zalin. See $\$ \mathbf{8 9}$. 
\$107. e (ä): dehnen, edel, gehege, heben, heer, legen, meer, reden, wehren; ähnlich, ähre, erwähnen, erzählen, grämen, käfig, lähmen, mähre, nähren, schämen, träne, wählen (MHG. weln), zähmen, zähre, and in the second and third pers. sing. of the present of strong verbs, fährst (MHG. ver(e)st), fährt (MHG. ver(e)t), gräbst, gräbt, schlägst, schlägt. On forms like gewöhnen, löze, schwören, see \$92.

$\S 108$. ë: befehlen, bewegen, dem (MHG. dëm(e)), eben, eber, empfehlen, geben, gelegen, genesen, geschehen, gezwesen, hehlen, kehle, kleben, leben, leber, leder, lesen, nehmen, pflegen, regen, scheren, segen, sehen, sehne, stehlen, streben, weben, wem (M HG. wëm(e)), zehn; mehl, steg, weg, see § 89. But the vowel has remained short in neffe (MHG. nëve). ziemen (MHG. zëmen) has been formed from ziemt (MHG. zimet).

Although the writing of e for old ë has generally remained in NHG., several words now have ä due to the influence of Alenianic orthography, viz. bär, gebären, gähnen, gähren, gewähren, häher (jay), jäten, käfer, quälen, räder (sieve), säge, schwäher, schwäre, spähen, stärke (young cow), strähne, verbrämen, wägen (to weigh), währen.

On the pronunciation of the $\ddot{a}, e, \ddot{e}$ in $\$ \$ 107-8$, see $\S 90$.

\$109. i : biber, biene, dieser, friede, ihm (MHG. im(e)), liegen, riese, sieben, wiebel, wiese, wiesel; in the second and third pers. sing. of the present of many strong verbs, as liest (MHG. lisest), liest (MHG. liset), similarly in siehst, steht; gebierst, gebiert, \&c. ; with late shortening in gibst (MHG. gibest), gibt (MHG. gibet), probably also in nimmst (MHG. nimest), nimmt (MHG. nimet); in the pret. plural and pp. of many strong verbs, as blieben (MHG. bliben), geblieben (MHG. gebliben), similarly in liehen, geliehen; mieden, gemieden; rieben, gerieben; schrieben, geschrieben; stiegen, gestiegen; trieben, getrieben; glied, sieb, sieg, spicl, vieh, viel, ziel, see \$ 89. Short in zinn 
\$ 110-4] The NHG. Vowels

(MHG. zin), but zien was common in the sixteenth and seventeenth centuries.

On the writing of ie for $\bar{i}$, see $\S 136$.

§110. o: boden, bogen, honig, hose, kohle, loben, oben, oder, ofen, vogel, wohnen; in the pp. of many strong verbs, as gebogen, geboren, geflogen, gehoben, gelogen, geschoben, getrogen, gezogen; grob, hof, hohl, lob, moos, sohn (§ 97), tor (OHG. tor), wohl (OHG. wola).

The old uninflected form has been generalized in fromm (\$ 97), toll.

§111. u : jude, jugend, kugel, muhen (MHG. muhen, muwen, to moo), stube, tugend, truhe (MHG. truhe, trunk); flug, lug, spur, zug, see § 89.

§112. ö: gewöhnen, löwe, schwören, see §92; börse, könig, mögen, söhne, see §1.01.

§113. ì : bühne, für (MHG. vür, OHG. furi), pl. flüge, flügel, gebühr, gebühren, lïge, mühle, pfühl (M HG. pfuilwe), prügel (late $\mathrm{MHG}$. brügel), rüde (M HG. rüde, large hound), tür (türe); shortened in hübsch (M HG. hübesch, hübsch).

\$114. Short vowels in open syllables, when followed by a suffixal -el, .en, -er in the next syllable, have sometimes been lengthened, and have sometimes remained short. The vowel was regularly lengthened when $1, n, r$ were vocalic and remained short when they were consonantal. In the uninflected forms $\mathbf{1}, \mathbf{n}, \mathbf{r}$ (the e was merely graphical) were vocalic, but in the inflected forms they were consonantal. The lengthening regularly took place in the former case, but not in the latter, and then one or other of the forms was generalized.

Words containing MHG. $m$ or $\mathbf{t}$ have for the most part preserved the short vowel.

el : hammel, himmel, kümmel, sammeln, schimmel, semmel, tummeln, but schemel; bettel, biittel, knüttel, kutteln, sattel, schütteln.

en: genommen, kommen, zusammen, but namen, nehmen, 
schämen, ziemen; bitten (OHG. bitten), geglitten, gelitten, geritten, geschnitten, geschritten, gestatten, gesotten, schatten, schlitten, schütten, but beten, geboten, getreten, kneten, knoten, jäten, spaten, treten, waten.

er : ammer, dämmern, hammer, kammer, nummer, schimmer, schlummer, sommer, trümmer; söller; donner; widder; wneder, again, beside wider, against ; butter, dotter, gatter, gevatter, gewitter, gitter, lotter-, otter, schmettern, vetter, wetter, wittern, zither, zittern, zwitter, but kater, vater.

$\S 115$. Short vowels in open syllables, when followed by $\mathbf{t}$, have generally remained short, as bitte, blatt, bottich, brett, bütte, gatte, glatt, gott, kette, kitt, lattich, matt, matte, platt, platte, quitt, rettig, rotte, satt, schnitt, schnitte, schritt, stadt, stätte, sitte, spott, tritt, wittib, zotte. See $\$ \mathbf{8 9}$.

The only exceptions are: beet, bote, gebet, gebot, kröte, met, pate, pfote, schote, zote.

\section{B. The Long Vowels.}

§116. Of the eight MHG. long vowels, $\bar{a}, æ, \bar{e}, \overline{\mathbf{i}}, \overline{\mathbf{o}}, \overline{\mathrm{u}}$, $œ$, iu (= $\overrightarrow{\mathbf{u}})$, five, viz. $\overline{\mathbf{a}}, \mathfrak{x}, \overline{\mathrm{e}}, \overline{\mathrm{o}}, \propto$, have remained monophthongs in NHG., and three, viz. $\overline{\mathbf{i}}, \overline{\mathbf{u}}$, iu, have been diphthongized to ai (always written ei), au, oi (written eu, äu). See $\S 140$, note.

\section{$\overline{\mathbf{a}}$}

\$ 117. $\bar{a}$ has generally remained in NHG., as aal, aas, abend, ader, ahle, atem, bahre, braten, draht, fragen, gabe, gefahr, gnade, graf, haar, hake, jahr, klar, mass, nadel, plage, qual, raten, saat, schaf, schlafen, span, sprache, strasse, tat, wahn, wahr. And in the pret. pl. of many strong verbs, as gaben (MHG. gāben), similarly in assen, lasen, nahmen, sahen, sassen, sprachen, trafen, \&c.

$\overline{\mathbf{a}} \mathbf{w}$, with $\mathbf{w}$ mostly taken into the nominative from the inflected forms, has become au, as blau (MHG. blā, gen. 
blāwes), braue (MHG. brā beside brāwe), grau, klaue, lau, pfau.

$\S$ 118. $\bar{a}$ partly became ō in Bavarian, Middle German, and a part of Alemanic in the second half of the thirteenth century ( $\$ \mathbf{8 1}$, note $\mathbf{I}$ ). Several words containing this change have got into the NHG. literary language. This is especially the case when the vowel was followed by a nasal or preceded by $\mathbf{w}$. $\overline{\mathbf{a}}$ and $\bar{o}$ forms often occur side by side in the early writings of Luther. $\overline{\mathbf{o}}$ for older $\overline{\mathbf{a}}$ occurs in : argwohn (M HG. arcwān), dohle (MHG. dāhele), brodem (MHG. brādem), kot (MHG. quāt, kāt), mohn (MHG. māhen, mān), monat (MHG. mānōt), mond (M HG. māne), montag (M HG. māntac), odem (M HG. ādem), ohne (M HG. āne), ohnmacht (MHG. āmaht), from association with ohne in NHG., schlot (MHG. slāt), ton (MHG. tāhe), wo (M HG. wā, wār), woge (MHG. wāc), pret. pl. woben (MHG. wāben), wogen (MHG. wāgen); and with shortening before two consonants in brombeere (OHG. brāmberi), docht (MHG. tāht), see \$139.

$\S 119$. Long $\overline{\mathbf{a}}$ has been shortened in acht (prosecution), blatter, brachte, gebracht, dachte, gedacht, jammer, klafter, krapfen, nachbar, natter, rache, sacht, schach, waffe, wappen, see $§ 139$.

\section{æ}

$\S 120$. MHG. æ, the umlaut of $\overline{\mathbf{a}}$, was an open sound. In the language of the stage it has now become long close e, whether written e or ä. When written ä many people pronounce it as long open $\bar{æ}$. This distinction is arbitrary and is entirely due to the influence of the orthography. It is mostly written $\ddot{a}$ in NHG. irrespective as to whether there are related forms beside them without umlaut. Examples are : bähen, blähen, gebärde (also geberde), gefäss, gerät, gräfin, jäh, käse, krähen, mähen, märchen, nähen, säen, schäfer, spät, stätig (also stetig), träge, wähnen; the pl. 
of nouns, drähte, räte, spähne, \&c., pret. subj. of many strong verbs, as ässe, bräche, gäbe, läse, nähme, sähe, spräche, träte, \&c. It has been shortened in ansässig, schächer, truchsess, pret. subj. brächte, dächte, see $\$ 139$. It is not written ä in angenehm, bequem, drehen, leer, selig, schere (shears), schwer, stets, wehen.

\section{$\overline{\mathbf{e}}$}

§121. MHG. $\overline{\mathrm{e}}$ has generally remained in $\mathrm{NHG}$., as eher, ehre, ewig, ger, hehr, kehren (to turn), klee, lehren, mehr, schnee, see, seele, sehr, speer, weh, wenig, zehe. It has been shortened in echt, herrlich, herrschaft, herrschen, lerche, see $\$ 139$.

\section{$\overline{\mathbf{o}}$}

\$122. MHG. $\overline{0}$ has generally remained in NHG., as bloss, bohne, brot, gross, floh, froh, hoch, kohl, lohn, los, moor, not, ohr, ostern, roh, rot, trost, tod, tot; in the pret. of some strong verbs, as bot, floh, fror, verlor. It has been shortened in amboss, genosse, hochzeit, hoffart (M HG. hōchvart), lorbeer, flöss (raft), pret. of strong verbs floss, genoss, goss, schloss, schoss, verdross, see §139.

$œ$

$\S 123$. MHG. œ has remained in NHG., written ö, as blöde, böse, höhe, höher, höhnen, hören, lösen, öde, röhre, schön.

The Diphthongization of MHG. $\overline{\mathbf{i}}, \overline{\mathbf{u}}$, iu.

$\S$ 124. The diphthongization took place earliest in Bavarian, where $\bar{i}, \overline{\mathbf{u}}, \mathbf{i} u$ had become ei, ou, eu (äu) by the end of the twelfth century, and then ou became au in the fourteenth century. In Swabian it took place in the fifteenth century. In Alemanic (except Swabian) the monophthongs remained until the early NHG. period. In East Middle German the diphthongization took place in the early part of the fourteenth century, but in West Middle 
\$1 125-7] The NHG. Vowels

German not until the beginning of the sixteenth century. From then onwards the diphthongs became the recognized forms except in Switzerland where the old monophthongs were retained in writing until about 1580 in Basle and between 1650 and 1675 in Zurich.

The old long vowels have remained to the present day in the Alemanic (except Swabian) and many Middle German dialects. So that in these dialects MHG. $\overline{\mathbf{1}}$ and ei, $\overline{\mathbf{u}}$ and ou, $\mathbf{i u}$ and öu (eu) have not fallen together as in the NHG. standard language.

\$125. MHG. i has become ai in NHG., but it is always written ei, as bei, beissen, blei, bleiben, dein, drei, eilen, eis, eisen, eitel, feind, frei, gedeihen, gleich, greifen, heirat, leib (body), leicht (adj.), leiden, leihen, leim, meiden, meile, mein, neid, preisen, reiben, reich, reissen, reiten, scheinen, schleifen, schmeissen, schreiben, schreien, sclireiten, schweigen, schwein, seide, sein, seite, steigen, sireit, treiben, weib, weichen, wein, weit, zeit, zweifel.

§126. MHG. $\overline{\mathfrak{u}}$ has become au in NHG., as auf, aus, aussen, bau, bauch, brauchen, braun, braut, daumen, faul, faust, haufe, haus, haut, kaum, kraut, laune, laut, maus, raum, sau, sauber, saufen, schaum, tausend, taube, traube, traut.

brauen and kauen are the Middle German forms corresponding to MHG. brūwen and kūwen; beside these there existed in MHG. (Upper German) briuwen and kiuwen which would have become bräuen (breuen) and käuen (keuen) in NHG. breuen is often found in early NHG. and is still used in the Upper German dialects. käuen (keuen) was common in eighteenth-century literature, and is still preserved in wiederkäuen.

MHG. ūw has become au in bauen (MHG. būwen), trauen (MHG. trūwen).

$\S 127$. MHG. iu has become oi (written, äu, eu) in NHG. See $\$ 140$, note. 
It has been stated in $\S 85$ that $\mathrm{MHG}$. iu partly represents OHG. iu and partly the umlaut of OHG. $\overline{\mathbf{u}}$. The two sounds fell together in $\tilde{\mathbb{u}}$ (written iu) about the year 10oo. Although the two sounds fell together so early, they are still partly distinguishable in NHG. orthography. With one or two doubtful exceptions, the NHG. development of MHG. iu (= OHG. iu) is always written eu ; whereas äu is used as the umlaut of MHG. $\overline{\mathbf{u}}$ where umlauted and non-umlauted forms exist side by side, as haus, haut, kraut, maus, pl. häuser, häute, kräuter, mäuse. When no non-umlauted forms exist, the umlaut is generally written eu.

Examples of eu (=OHG. iu) are : deuten, deutsch, euch, freund, heulen, heute, leuchten, leumund, leute, neu, neun, reuten, teufel, treu, zeug, but bläuen (OHG. bliuwan, to strike) and possibly räuspern (to clear the throat).

Examples of eu (= MHG. umlaut of $\overline{\mathbf{u}})$ are: beule, beutel, eule, euter, feucht, greuel beside gräuel, heucheln, keuchen, keusch, kreuz, meuchelmord, reuse, schleunig, schneuzen, seufzen.

Examples of the umlaut, written äu are : äussern, bräutigam, fäule (filth), häuser, häuslich, häute, gesträuch, läuten, mäuse, räude, säule (with äu from the old plural, MHG. sūl, pl. siule), sträuben, sträucher, sich täuschen. räumen (MHG. rūmen), säumen (MHG. sūmen), säumig (MHG. sūmic) are from the old Middle German forms, see $\$ 79$. spreizen, older NHG. spreutzen (MHG. spriutzen), steiss, older NHG. steuss (MHG. stiuz), have crept into the literary language from dialects which have unrounded äu (eu) to ei.

\$128. An e has been developed in closed syllables before $\mathbf{r}$ after NHG. ei, eu, au from MHG. $\bar{i}, \mathbf{i u}, \overline{\mathbf{u}}$, as feier (MHG. vire), geier (MHG. gìr), leier (MHG. lïre); abenteuer (MHG. āventiure), feuer (MHG. viur), geheuer (MHG. gehiure), heuer (MHG. hiure, OHG. hiu jāru), 
schener (MHG. schiure), tener (MHG. tiure); baner (MHG. gebūr), maner (MHG. mūre), sauer (MHG. sūr), schaner (MHG. schūr), trauer (M HG. trūre).

\section{The Diphthongs.}

\$129. Of the six MHG. diphthongs, ei, ie, ou, uo, öu (eu), üe, three, viz. ei, ou, öu, have remained diphthongs in NHG. and ie, uo, uie have become monophthongs.

ei

\$130. MHG. ei has become ai (written ei, rarely ai) in NHG. The change from ei to ai took place in Bavarian and Swabian in the early part of the thirteenth century. Examples are: ameise, arbeit, beide, bein, bleich, breit, ei, eiche, eid, eigen, ein, eiter, fleisch, geil, geist, gemein, heide, heil, heilen, heim, heiss, heissen, kein, kleid, klein, leid, leisten, leiten, meinen, nein, scheiden, schweifen, seife, seil, teil, teilen, weich, weinen, weiss (I know), zeichen, zeigen.

Written ai in haide beside heide, hain, kaiser, laib (loaf), laie, Mai, saite (string), waide, waise (orphan).

It has been shortened to e in elf, elster, nelke, and to a in zwanzig, see $\$ 139$.

\section{ou}

$\S 131$. MHG. ou has become au in NHG., as auch, aue, auge, baum, frau, gau, glaube, hauen, laufen, lauch, laub, laube, raub, rauch, saum, schauen, staub, taub, traum, zaum.

$$
\text { öu (eu) }
$$

§132. MHG. öu (eu) has become oi (written äu, eu) in NHG., and has thus fallen together with NHG. äu (eu) from MHG. iu. In the MHG. period the umlaut was often written oi in Middle German and also occasionally in Upper German. It was written eu in Bavarian as early as the twelfth century. 
äu is now used as the umlaut of au (= MHG. ou) where umlauted and non-umlauted forms exist side by side, in other cases eu is used. Many of the forms with äu given below are late analogical formations based upon older models.

Examples are: bäume, sich bäumen, betäuben, older NHG. dräuen (to threaten), ersäufen, fräulein, gläubig, häupter, käufer, läufe, läufer, läufst, läuft, räuber, säugen, säumen, stäuben, stäublein, täufling, träufeln, träumen, träumerisch, zäumen; and with eu: beugen, epheu, freude, heu, leugnen beside läugnen (= older NHG. laugnen), streu, streuen.

$\S$ 133. In MHG. the umlaut of ou did not take place before labials in Upper German $(\$ \mathbf{7 9}$, ou), as Upper German gelouben (OHG. gilouben, older *galaubjan), houbet (OHG. houbit) beside Middle German gelöuben, höubet which in Luther appear as gleuben, heupt. In early NHG. there was quite a number of words which generally had the Middle German umlauted forms, but many of them have now disappeared from the literary language, their place having been taken by the Upper German forms, such are : erlauben, glauben, haupt, kaufen, raufen, taufe, taufen, zaubern.

$\S 134$. ereignis for older eröugnis occurs already in the sixteenth century; sich ereignen (MHG. eröugen); schleife, older NHG. schläufe (MHG. slöufe, a slip-knot). These forms have crept into the literary language from dialects which have unrounded äu (eu) to ei.

The Monophthongization of MHG. ie, uo, üe.

\$135. In Middle German the diphthongs ie, uo, uie became contracted to $\overline{\mathbf{i}}$ (written ie), $\overline{\mathbf{u}}$, and $\overline{\mathbf{u}}$ in the thirteenth century, but remained diphthongs in Upper German and the greater part of East Franconian, where 


\section{\$ 136-8] The NHG. Vowels}

with various modifications, they have been preserved in the dialects down to the present day.

§136. MHG. ie has become $\overline{\mathbf{i}}$ (written ie) in NHG. This explains why the $\mathbf{i}$, which arose from old short $\mathbf{i}$ in open syllables, is written ie ( $(109)$.

Examples are: bier, brief, dieb, dienen, fieber, hier, knie, krneg, lied, lieb, miete, priester, tief, tier, zuegel; in the present of many strong verbs, as biegen, bieten, fliegen, fliehen, fliessen, frieren, geniessen, giessen, kriechen, riechen, schieben, schiessen, schliessen, sieden, triefen, verdriessen, verlieren, ziehen ; in the pret. of the old reduplicated verbs, as blies, briet, fiel, hieb, hielt, lief, liess, rief, riet, schlief, stiess.

It has been shortened to $\mathbf{i}$ in dirne, fichte, fing, ging, hing, immer, licht, nimmer, viertel. See §139.

Note.-Lügen (MHG., also Luther liegen) has been formed from the noun lüge, and similarly trügen (MHG. triegen) has arisen from association with trug. demut (MHG. diemuot) is a Middle Franconian form which has crept into the literary language. In this dialect ie partly became $\bar{e}$ already in the MHG. period.

\$ 137. MHG. wo has become $\overline{\mathbf{u}}$ in NHG., as bube, buch, bude, behuf, blume, blut, bruder, bug, fluchen, flut, fuder (cart-load), fuss, grube, gruss, gut, huhn, husten, hut, klug, kuchen, kuh, mut, pflug, rufen, ruhm, schuh, suchen, stuhl, tuch, tun, wucher, wut; in the pret. of strong verbs, as grub, lud, schlug, schuf, trug.

It has been shortened to $\mathbf{u}$ in futter, genŭg, muss, musste, mutter, ruchlos, wuchs, wusch. See \$139.

Note.-Almosen (MHG. almuosen), pret. hob, schwor (MHG. huop, swuor), are Middle Franconian forms, which have crept into the literary language. In this dialect uo partly became $\mathbf{0}$ in the MHG. period.

\$138. MHG. uie has become $\overline{\mathrm{u}}$ in NHG., as blühen, blüte, brühe, bücher, drüse, früh, fügen, fühlen, führen, füsse, 
genügen, glühen, grün, güte, hühner, küfer, kühl, kühn, müde, mühen, prïfen, rïbe, rïhren, spïlen, sühne, süss, trïbe, wïhlen.

It has been shortened in brïllen, geriucht, milssen, miltter, nüchtern, rüssel. See \$139.

Nore.-In Middle and Upper German dialects $\overline{\mathbf{u}}$ has been unrounded to $\overline{\mathbf{i}}$. mieder (MHG. müeder, still muider in the seventeenth century) has got into the literary language from these dialects.

\section{The Shortening of Long Vowels.}

§ 139. The MHG. long vowels $(\overline{\mathbf{a}}, \mathfrak{x}, \overline{\mathbf{e}})$, which were not diphthongized in NHG., and the NHG. long vowels ie, $\overline{\mathbf{u}}$, $\overline{\mathbf{u}}$ which arose from the MHG. diphthongs, have often been shortened before consonant combinations, but in the great majority of words the long vowels have remained before consonant combinations. The shortening took place earliest in Middle German, where traces of it are found in monuments belonging to the early part of the thirteenth century. But as the shortening took place in the various dialects at different periods, it is impossible to lay down any hard-and-fast rules. It occurs most frequently before consonant combinations in compounds and derivatives, before cht, hs, ss (= MHG. 3, Germanic t), in words containing a suffixal -el, -en, -er, before ng, and in a few other words containing consonant combinations or ch. In several cases the shortening has been caused by shifting of the stress. Apart from consonant combinations, it will be seen that those factors, which prevented the lengthening of short vowels in open syllables, have often been the cause of the shortening, especially in words containing ss, ch ( $\$ 105$, note), and the suffixal elements -el, .en, -er (\$114). Examples are:

bar: barfuss, OHG. brāmberi (\$ 118): brombeere, dame : 
dambrett, dieser: diesseits, heer: herberge, herzog, MHG. hërlich: herrlich, MHG. hērschaft: herrschaft, hoch: hochzeit, hoffart, jener: jenseits, MHG. lōrber: lorbeer, MHG. nāchgebūre : nachbar, MHG. ruochlōs : ruchlos, uralt: ürteil, vier: viertel, vierzehn, vierzig, vor: vorteil.

MHG. āhte (prosecution) : acht, MHG. brāhte : brachte, gebracht, pret. subj. MHG. bræhte : brächte, MHG. dāhte : dachte, gedacht, pret. subj. MHG. dæhte: dächte, MHG. dihte : dicht from Low German, MHG. èhaft : echt from Low German, MHG. viehte: fichte, MHG. gerüefte : gerücht from Low German, MHG. lieht: licht, $\mathrm{MHG}$. nüehtern : nüchtern, Low German sācht: sacht, MHG. tāht (§ 118) : docht.

MHG. wuohs : wuchs, MHG. dræhsel: drechseln, drechsler.

MHG. anebōz : amboss, MHG. ansæze : ansässig, MHG. vlōz : flŏss (raft), MHG. genōz : genosse, MHG. lāzen : lassen, MHG. müezen, muoz, muoste : müssen, muss, musste, MHG. ruoz : rŭss, rŭssig, MHG. rüezel : rüssel, MHG. truhsæze: truchsess, pret. MHG. gōz : goss, and similarly in floss, genoss, schloss, schoss, verdross.

MHG. blāter(e) : blatter, MHG. vuoter : futter, MHG. iemer : immer, MHG. jāmer : jammer, MHG. muoter, pl. müeter : mutter, mütter, OHG. nātara : natter, MHG. niemer: nimmer, MHG. wāpen : wappen.

Pret. MHG. vienc, gienc, hienc: fing, ging, hing. This shortening took place in Middle German in the MHG. period. Luther has fieng beside fing.

MHG. dierne : dirne, OHG. hērisōn : herrschen, OHG. lērahha: lerche, MHG. rāche: rache, MHG. schāch : schach, MHG. schæchære: schächer, MHG. genuoc : genŭg, MHG. klāfter, krāpfe, wāfe: klafter, krapfen, waffe, MHG. stuont: early NHG. stund, MHG. hāst, hāt, hāte : hast, hat, hatte.

ei has been shortened to e in elf (MHG. eilf, einlif), 
elster (M HG. eilster, older agelster), nelke (M HG. neilkīn, older negelkin), and to a in zwansig (MHG. zweinzic).

dar: dăra'n, dărau's, her: hĕrei'n, hĕrau's, probe: prŏbie'ren, viel : vielleicht (M HG. vil lïhte), vor: vŏra'n, vŏrau's, wohl: wŏhla'n.

$\$ 140$. Summing up the results of Chapter VI, we arrive at the following vowel-system for the NHG. period:-

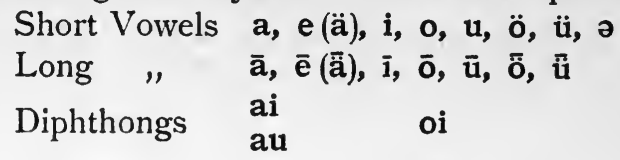

Note.-Where in the standard language a difference is made in the pronunciation of e and $\ddot{a}$, the latter is more open than the former $(\$ 80)$. $\quad$ is the e in unstressed syllables, as in gabe, hatte, \&c. Where a distinction is made in pronunciation between $\overline{\mathbf{e}}$ and $\bar{a}$ the former is close and the latter open. $\overline{\mathbf{i}}$ is generally written ie or ih, as in miete, ihm. With few exceptions (\$130) $\mathbf{a} \mathbf{i}$ is always written ei ; and oi is always written eu (äu). The diphthongs ai and au are pronounced as ae and ao by many Germans, and the latter are regarded as the standard pronunciation by some of the best phoneticians. oi from MHG. $\overline{\mathrm{i}}$ (through the intermediate stages iii, öii, oii) varies in pronunciation in the different parts of Germany. Some phoneticians regard oii, or oö with the first element very open, as the standard pronunciation.

\section{CHAPTER VII}

THE MHG. EQUIVALENTS OF THE NHG. VOWEL-SYSTEM IN ACCENTED SYLLABLES

A. The Short Vowels.

§141. $\mathrm{a}=$ (I) MHG. a, as band, gast, kalt (\$ 91).

=(2) MHG. $\overline{\mathbf{a}}$ shortened before consonant combinations, as blatter, dachte (§139). 
\$142. $\ddot{a}=(\mathrm{I}) \mathrm{MHG}$. e, as gäste, lämmer, länger (\$ 92).

$=$ (2) M HG. ä, as mächte, kälber (\$ 93).

=(3) MHG. æ by shortening, as ansässig, schächer (\$138).

§143. $\mathbf{e}=(\mathrm{I}) \mathrm{MHG}$. ë, as feld, herz, helfen (§ 94).

= (2) MHG. e, as denken, henne, streng (\$ 92).

=(3) rarely MHG. ē by shortening, as echt, lerche (\$139).

§144. $\mathbf{i}=(\mathrm{I})$ MHG. $\mathbf{i}$ as bild, binden, wrssen (\$ 95).

$=(2)$ rarely MHG. $\mathrm{u}$, as findling, kissen (\$102).

=(3) rarely MHG. ie by shortening, as fing, hing (§ 139).

\$145. $\mathrm{O}=$ (I) MHG. o, as dorf, holz, geholfen ( $\$ 96)$.

= (2) MHG. u before nasals, as sonne, begonnen, sommer (\$ 97).

= (3) rarely $\mathrm{MHG}$. ō by shortening, as hochzeit, genosse, schoss (\$139).

§ 146. $\mathfrak{u}=$ (I) M HG. u, as burg, hund, gebunden (\$ 97).

=(2) MHG. $\ddot{i}$ before certain consonant combinations in Upper German, as dulden, kunde (\$ 100).

=(3) rarely $\mathrm{MHG}$. uo by shortening, as futter, mutter, wuchs (\$139).

§147. $\ddot{\mathrm{o}}=$ (I) MHG. ö, as in dörfer, töchter (\$ 98).

$=(2)$ MHG. $\mathrm{e}$ in the neighbourhood of labials,

1, sch, as hölle, löffel, löschen (\$ 92).

= (3) MHG. ü before nasals, as gömnen, können (§ 101).

§ 148. $\ddot{\mathrm{u}}=(\mathrm{I}) \mathrm{MHG}$. $\ddot{\mathrm{u}}$, as diurftig, fülle, kürze (§ 99).

=(2) rarely MHG. i, as fünf, mïnze (\$ 95).

$=(3)$ rarely MHG. uie by shortening, as mïtter, müssen (§ 139). 


\section{B. The Long Vowels.}

§149. $\overline{\mathbf{a}}=$ (I) MHG. $\bar{a}$, as abend, nadel, saat (\$117).

=(2) MHG. a in open syllables, as baden, sagen, zahl ( $\$ 106)$; before final $r$, as dar, gar (\$ 103); before $\mathbf{r}+$ dental, as art, fahrt (\$ 104).

§ 150. $\bar{a}=$ (I) MHG. æ, as nähen, spät, träge (\$ 120).

=(2) MHG. ë in open syllables; as bär, gähren, quälen (\$ 108).

=(3) MHG. e (ä) in open syllables, as ähre, träne, wählen (\$ 107).

§151. $\overline{\mathrm{e}}=$ (1) MHG. $\overline{\mathrm{e}}$, as chre, lehren, mehr (\$121).

$=(2)$ MHG. æ, as bequem, leer, selig (\$120).

$=(3)$ MHG. e in open syllables, as dehnen, edel, heben (\$107).

=(4) M HG. ë in open syllables, as geben, mehl, nchmen ( $(108)$; before final $\mathbf{r}$, as er, wer $(\$ 103)$; before $\mathrm{r}+$ dental, as erde, weraien (\$ 104).

§152. $\overline{\mathrm{i}}=(\mathrm{I}) \mathrm{MHG}$. ie, as brief, biegen, hielt (\$136).

=(2) MHG.i in open syllables, as friede, liegen, sieben, sieg (\$109).

=(3) MHG. i before final r, as $i h r, \operatorname{mir}(\$ 103)$.

§153. $\overline{\mathrm{o}}=$ (I) M HG. o, as hoch, lohn, $\operatorname{rot}(\$ 122)$.

=(2) rarely MHG. $\overline{\mathbf{a}}$, as ohne, monat, wo (\$118).

= (3) MHG. 0 in open syllables, as honig, vogel, hof (\$ 110).

=(4) MHG. o before final r, as empor, vor (§ 103).

§154. $\overline{\mathrm{u}}=$ (I) MHG. uo, as buch, huhn, stuhl (\$ 137).

=(2) MHG. $\mathbf{u}$ in open syllables, as flug, jugend, kugel (\$ 111). 
§155. $\check{0}=$ (I) MHG. œ, as böse, hören, öde (\$123).

=(2) MHG. $e$ in open syllables in the neighbourhood of certain consonants, as gewöhnen, löwe, schwören (\$ 92).

=(3) rarely $\mathrm{MHG}$. $\ddot{\mathbf{u}}$ in open syllables before $\mathrm{n}$, as könig, söhne (§ 101).

§158. $\overrightarrow{\mathrm{u}}=$ (I) MHG. üe, as blïte, fühlen, kïhl (\$ 138).

$=(2)$ MHG. ï in open syllables, as flügel, lïge (§ 113).

C. The Diphthongs.

§157. ai = MHG. ei, as hain, kaiser, Mai (\$ 130). $\S 158$. ei $=(\mathrm{I})$ MHG. ei, as arbeit, teil, klein (\$130). =(2) MHG. i, as bleiben, frei, schreiben (\$125). \$159. au = (I) MHG. ou, as auge, laufen, $\operatorname{traum}(\$ 131)$. $=(2)$ MHG. $\bar{u}$, as braun, laut, tausend ( $(126)$. =(3) rarely MHG. $\overline{\mathbf{a}} \mathbf{w}$, as blau, lau (\$ 117). $\S 160$. eu (äu) $=(\mathrm{I})$ MHG. iu, as deutsch, leute, häuser, läuten (\$ 127).

$=(2)$ MHG. öu (eu), as bäume, beugen, räuber (\$132).

\section{CHAPTER VIII}

THE HIGH GERMAN DEVELOPMENT OF THE PRIMITIVE GERMANIC VOWELS OF UNACCENTED SYLLABLES

I. The Old High German Period.

$\$ 161$. Before formulating the laws which govern the treatment of the vowels in final syllables, it will be useful to state here the laws relating to the treatment of final consonants in prehistoric High German. 
(I) Final $\cdot m$ became $\cdot n$, and then it, as also Indg. final -n, disappeared already in primitive Germanic. When the vowel, which thus became final, was short, it had the same further development as if it had been originally final, as OHG. joh, Goth. juk, Lat. jugum, Gr. Suyóv, yoke; acc. sing. OHG. wolf, Goth. wulf, Lat. lupum, Gr. 入v́коv, wolf; acc. OHG. Goth. gast, cp. Lat. turrim, tower; OHG. gen. pl. tago, of days, cp. Gr. $\theta \epsilon \hat{\omega} v$, of gods; OHG. nom. zunga, tongue, hërza, heart, orig. ending -ōn.

(2) The final Indg. dental explosives disappeared in prim. Germanic, except after a short accented vowel, as pres. subj. OHG. bëre, Goth. baírái from original form *bheroĩt, he may bear; OHG. bārun, Goth. bērun, they bore, original ending , nt with vocalic n $(\$ 49)$; OHG. māno, Goth. mēna from "mēnōt, moon; but OHG. daz, Engl. that, from *tod beside OHG. deih = that $I$; OHG. hwaz, Engl. what = Lat. quod, beside OHG. weih, what $I$; OHG. az, Engl. at = Lat. ad.

(3) The West Germanic treatment of Indg. final -s has not yet been satisfactorily explained. In prehistoric High German it became $z$ by Verner's law ( $\$ 199)$, and then later $\mathbf{r}$. This $\mathbf{r}$ has been preserved in German in a few unstressed forms of the personal pronouns, as mir, dir, er, wir = Goth. mis, pus, is, weis. In other cases the final $\cdot z$ disappeared in prehistoric High German, as OHG. $\operatorname{tag}=$ Goth. dags, day; pl. nom. OHG. taga =Goth. dagōs ; OHG. gast =Goth. gasts, guest $;$ pl. OHG. gesti = Goth . gasteis, $\mathrm{OHG}$. sunu = Goth. sunus, son .

Note.-It is difficult to account for the final -s in certain personal endings of verbs, viz. in the first pers. pl. pres. indic. OHG. nëmames, we take; in the second pers. sing. of the pres. and pret. subj., nëmēs, nāmis; and in the second pers. sing. of the pret. of weak verbs, as neritōs, thou didst save. This $\cdot \mathbf{s}$ must not be confused with the $s$ which became final after the loss of a vowel, as in nimis from *nemesi, thou takest; gen. dës, from 
\$162] OHG. Vowels of Unaccented Syllables 7 1

*teso, of the; hwes from *qeso, whose, and similarly in the gen. of nouns, tages, \&c.

(4) Indg. final -r remained, as OHG. fater, Goth. fadar,

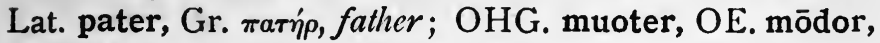

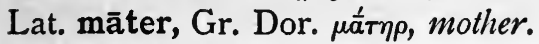

$\S 162$. I. Final long vowels, inherited from primitive Germanic, became shortened already in primitive High German :

-ō became u, as OHG. biru from *berō $=\mathrm{Gr}$. фé $\rho \omega, I$ bear; instr. sing. OHG. tagu from *dazō, by day.

$-\mathbf{i}$ became $\mathbf{i}$, as OHG. pret. subj. $r$. and 3 . pers. sing. nāmi beside 3. pers. pl. nāminn, they might take.

These short vowels then underwent the same further development in OHG. as original final short $\mathbf{u}$ and $\mathbf{i}$. See below.

2. a (=Indg. a and o), which was originally final or became final through the loss of a following consonant, disappeared in dissyllabic and polysyllabic forms already in prim. High German.

$\mathbf{u}$ and $\mathbf{i}$, which were originally final or became final through the loss of a consonant, disappeared in trisyllabic and polysyllabic forms. They, as well as the $\mathbf{u}$ and $\mathbf{i}$, which arose from the shortening of $\overline{\mathbf{o}}$ and $\bar{i}$, disappeared also in dissyllabic forms when the first syllable was long, but remained when the first syllable was short. The regular operation of this law was often disturbed by analogical formations.

Regular forms were: $\mathrm{OHG}$. weiz $=\mathrm{Gr}$. oi $\delta$, I know ; OHG. weist $=$ Gr. oi $\sigma \theta a$, thon knowest; OHG. nom. wolf from ${ }^{*}$ wulfaz $=\mathrm{Gr}$. $\lambda$ v́кos, wolf; OHG. acc. wolf from ${ }^{*}$ wulfan $=\mathrm{Gr}$. $\lambda$ v́коv; OHG. bëran from *beranan, preGermanic *bheronom, to bear; OHG. weiz = Gr. oijo, he knozus; OHG. fimf, finf $=\mathrm{Gr}$. $\pi \dot{v} v \tau \epsilon$, five; OHG. voc. wolf = Lat. lupe, Gr. $\lambda v^{\prime} \kappa ;$ OHG. pret. 3. pers. sing. kōs, he chose, bant, he bound, from *kausi, *bandi, pre- 
Germanic *gouse, *bhondhe. Final er remained in OHG. when not followed by a palatal vowel, as OHG. acc. fater $=$ Gr. $\pi a \tau$ ćpa, father $;$ OHG. acc. muoter $=$ Gr. Attic

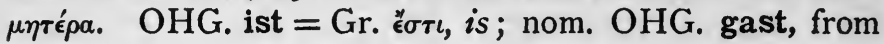
*zastiz, guest = Lat. hostis, stranger, enemy ; OHG. nimis, thou takest, nimit, he takes, from *nemesi, *nemeti; OHG. meri, sea, from older ${ }^{*}$ mari, cp. Lat. pl. maria; OHG. wini from older *winiz, friend. OHG. tōd = Goth. dáu. pus, death; OHG. fluot = Goth. flōdus, flood; pl. OHG. wort = Goth. waúrda, Lat. verba, words; OHG. fihu = Goth. faíhu, cattle; OHG. sunu = Goth. sunus, son; OHG. situ = Goth. sidus, custom; OHG. biru = Gr. $\phi \dot{c} \rho \omega$, $I$ bear. Then after the analogy of these and similar forms were made stat for *steti, place; sun beside sunu, son; nim for nimi = Gr. $\nu^{\prime} \mu \epsilon$, take thou; hilfu for *hilf, I help; joh for *johu, yokes; faz for *fazu = OS. fatu, vats.

3. The Indg. long diphthongs -ōi, -ōu became shortened to ai, au in prim. Germanic, and then underwent the same further changes as old -ai, -au, that is, they became $\cdot \bar{e}, \cdot \bar{o}$ in West Germanic.

Later than the shortening mentioned under I, occurred the shortening which was experienced in dissyllabic and polysyllabic words by the long vowel, after which an $\cdot \mathbf{n}$ or $\cdot \mathbf{z}$ had disappeared, and by the $\cdot \overline{\mathrm{e}}$ and $\cdot \overline{0}$ from older -ai and -au, which were either already final in prim. Germanic, or had become so after the loss of $\cdot z$, as well as by the $\cdot \overline{\mathbf{i}}$ which had arisen from older $\cdot \mathbf{i j i}$. In this case a distinction must be made according as the long vowel originally had the 'slurred' (circumflex) or 'broken'

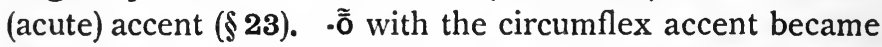
$\cdot \bar{a}$ after the loss of $\cdot z$, in other cases it became $\cdot 0$. $\cdot \overline{0}$ with the acute accent became $\cdot \mathbf{a}$ after the loss of $\cdot \mathbf{n}$, or $\cdot \mathbf{z}$. The $\cdot \overline{\mathrm{e}}$ and $\cdot \overline{0}$ from older $\cdot$ ai and $\cdot$ au became $\cdot e, \cdot 0$, and $\cdot \overline{1}$ became $\cdot \mathbf{i}$. All these shortenings took place in prehistoric High German. Examples are :-pl. OHG. gëbā = Goth. 
§ 163] $O H G$. Vowels of Unaccented Syllables 73

gibōs, gifts, (.õs); OHG. gen. pl. tago, of days, (.õn), cp. Gr. $\theta \epsilon \hat{\omega} v$, of gods; OHG. zungōno = Goth. tuggōnō, of tongues, (.õn); OHG. hano, cock, (.õn); OHG. gilīhho = Goth. galeikō, like, (.õd); OHG. taga = Goth. dagōs, days, (.ōz); OHG. hërza = Goth. haírtō, heart, (.ōn); OHG. acc. gëba, gift, (-ōn), cp. Gr. acc. $\chi \omega ́ \rho \bar{\alpha} v$, land; OHG. nom. pl. masc. blinte $=$ Goth. blindái, blind; OHG. pres. subj. bëre = Goth. baírái, he may bear; OHG. dat. tage, to a day, cp. Gr. loc. ö̌ko, at home, dat. $\lambda \dot{\kappa} \kappa \omega$, to a wolf; OHG. ahto $=$ Goth. ahtáu, eight ; gen. sing. $O H G$. suno $=$ Goth . sunaus, of a son; nom. pl. OHG. gesti = Goth. gasteis,

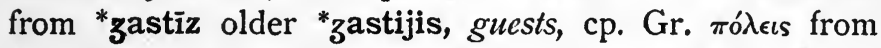
${ }^{*} \pi$ ó $\lambda_{\epsilon j \in s,}$ cities, imp. OHG. neri $=$ Goth. nasei, from *nazi older *naziji, Indg. *noséje, save thou.

\$163. OHG. short and long vowels remained in final syllables when followed by a consonant, as neut. sing. blintaz, blind; acc. inan, him; inf. hëlfan, to help; gen. tages, of a day; gen. dat. hanen, hërzen beside nom. hano, cock, hërza, heart; nom. acc. pl. lembir, lambs; dat. pl. enstim, to favours; nimit, he takes; ubil, evil; acc. hanon, cock; sibun, seven; dat. pl. tagum, to days; habēn, to have; nemès, thou mayest take; dat. pl. blintēm, beside nom. pl. blinte, blind; mahtig, mighty; tiurlìh, dear; dat. pl. hōhīm, to heights; nāmīs, thou mightest take; salbōn, to anoint; suohtōs, thou soughtest; dat. pl. gëbōm, zungōm beside nom. sing. gëba, gift, zunga, tongue; acc. gen. dat. sing. zungūn.

NotE.-I. Indg. o remained longer in unaccented than in accented syllables in prim. Germanic. It became a during the prim. Germanic period except (I) when followed by an $m$ which remained in historic times, and (2) when the following syllable originally contained $\mathbf{u}$. In these positions the o became $\mathbf{u}$ in

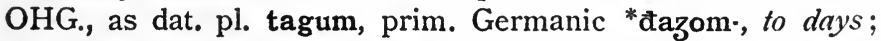
acc. sing. hanun from prim. Germanic *xanon-un, cock; acc. pl. hanun from prim. Germanic *xanon.unz. 
2. Prim. Germanic $\bar{e}, \bar{i}, \bar{o}, \overline{\mathbf{u}}$ when protected by a consonant in historic times remained in OHG., except that final -èr became -er, and $-\bar{o}$ when originally followed by $u$ in the next syllable became $\overline{\text { u. }}$ Examples are: OHG. habēn, to have, dagèn, to be silent, cp. Lat. habēre, silère, but OHG. fater $=\mathrm{Gr}$. $\pi a r \dot{\eta} \rho$, father; OHG. pret. subj. nāmīm, we might take, cp. Lat. velìmus ; OHG. salbōn from *salbōn-an, to anoint, but OHG. acc. zungūn from *tungōn.un, tongue, acc. pl. zungūn from *tungōn.unz. The $\bar{u}$ was then carried into the gen. and dat. sing. and nom. plural.

3. Final -jan became en, but -jen when preceded by $r$, as OHG. heffen = Goth. hafjan, to raise; OHG. nerien = Goth. nasjan, to save.

$\S 164$. The $\mathbf{i}$ in the preterite and past participle of weak verbs, Class I, was regularly syncopated after long stem syllables in prehistoric High German, as pret. OHG. hōrta, suohta, branta = Goth. háusida, I heard, sōkida, I sought, ga-brannida, I burnt, beside OHG. nerita = Goth. nasida, I saved; pp. OHG. gihōrt.ēr, gisuoht.ēr, gi. brant-ēr = Goth. háusips, sōkips, ga.brannips, beside ginerit.ēr = Goth. nasips.

$\S 165$. If a nasal or a liquid, preceded by a mute consonant, came to stand finally after the loss of a $(\$ 162,2)$, it became vocalic and then generated a new a before it in prehistoric High German, as nom. acc. ëban, even, from *ëbn, older *ëbnaz, *ëbnan, cp. Goth. ibns, ibnana ; nom. acc. fogal, bird, from ${ }^{*}$ fogl, older ${ }^{*}$ foglaz, ${ }^{*}$ foglan, cp. Goth. fugls, fugl ; nom. acc. ackar, field, acre, from *akr, older *akraz, *akran, cp. Goth. akrs, akr, \&c.

The a, thus generated, became transferred to the oblique cases also, at first after short syllables, and then later after long syllables as well, as fogales, wuntares, \&c.

$\$ 166$. Medial vowels were often assimilated to final vowels, as keisar, emperor, gen. keiseres ; wuntorōn, to wonder, beside wuntar; sibun, seven, beside inflected form sibini, \&c.

$\S 167$. In all OHG. dialects a vowel was developed be- 
\$ 168-70] MHG. Vowels of Unacc. Syllables 75

tween medial rh, $1 \mathrm{~h}$, as also before $\mathrm{w}$ in the combinations $\mathrm{rw}$, $1 \mathbf{w}$, and sw. The vowel thus developed appeared mostly as a or $\mathbf{0}$, but it not unfrequently regulated itself after the quality of a neighbouring vowel. Examples are :-bëraht = Goth. baírhts, clear; furhten, to be afraid, beside pret. forhta, forahta ; wurken, to work, beside pret. worhta, worahta; bifëlhan beside bifëlahan, to hide, bifiluhu, I hide, bifilihit, he hides; garo, ready, inflected form garwēr beside garawēr; mëlo, meal, flour, gen. mëlwes beside mëlawes, dat. mëlewe; zëswa, right hand, beside zësawa.

But the vowel thus developed disappeared again in MHG., and the above forms regularly became: bërht, forhte, worhte, befëlhen, garwer, melwes, zëswe.

$\$ 168$. Final $-u$ and $\cdot i$ became $\cdot 0$ and $\cdot e$ in the ninth century, as sunu, filu, fridu, tagu, blintemu, iru, meri, wini became suno, filo, frido, tago, blintemo, iro, mere, wine.

$\S 169$. The prim. Germanic vowels of unaccented syllables underwent few further changes beyond those dcscribed in $\S$ 162-8 until towards the end of the OHG. period, by which time the vowels had already begun to be weakened to $\mathrm{e}$.

\section{The Middle High German Period.}

$\$ 170$. One of the most characteristic differences between OHG. and MHG. is the weakening of the long and short vowels in inflexional syllables to a (written e). The weakening had already begun by the beginning of the tenth century, and spread considerably during this and the early part of the following century. It took place earlier when the vowels were followed by a consonant than when they were absolutely final. In the former case the short vowels had been weakened to e by the end of the OHG. period, but in the latter case a and o remained until the beginning of the MHG. period.

The weakening took place earlier in Middle German 
than in Upper German. The long vowels, followed by a consonant, were only shortened (not weakened to e) in Alemanic of the twelfth century. The weakened vowel a was generally written e in MHG., but it is often written $\boldsymbol{i}$ in Alemanic (occasionally also a) and Middle German. This writing of the indistinct vowel as $\mathbf{i}$ was especially common in Middle German down to the early part of the sixteenth century. It still occurs frequently in the early works of Luther.

Only a few examples are given here to illustrate what has been stated above, as the history of the vowels in inflexional syllables will have to be treated more fully in the Accidence :-

OHG. nom. pl. taga, days, nom. gen. acc. sing. gëba, gift, nom. sing. zunga, tongue, acc. sing. masc. blintan, blind, neut. nom. blintaz, blind, inf. nëman, pp. ginoman, became in MHG. tage, gëbe, zunge, blinden, blindez, nëmen, genomen.

Nom. sing. hirti, herdsman, kunni, race, nom. pl. gesti, guests, gen. pl. lembiro, dat. pl. gestin, nimis(t), thou takest, nimit, he takes, nāmi, thou tookest, became in MHG. hirte, künne, geste, lember(e), gesten, nimest, nimet, næme.

Gen. pl. tago, gesto, dat. pl. tagon, lembiron, nom. sing. boto, messenger, nom. acc. pl. fem. blinto, became MHG. tage, geste, tagen, lember(e)n, bote, blinte.

Acc. sing. nom., acc. pl. botun, nimu, I take, pret. pl. nāmum, nāmut, nāmun, became MHG. boten, nime, nāmen, nāmet, nāmen.

Nom. pl. gëbā, gifts, became MHG. gëbe.

Nom. sing. masc. blintēr, blind, dat. pl. blintēm, unsēr, our, iuwēr, your, nëmēs(t), thou mayest take, pl. nëmēn, habēn, to have, became MHG. blinder, blinden, unser, iuwer, nëmest, nëmen, haben.

scōnī, beauty, nāmīs(t), thou mightest take, nāmīm, we might take, became MHG. schœne, næmest, næmen. 
§ 17r] $M H G$. Vowels of Unaccented Syllables 77

Gen. pl. gëbōno, botōno, hërzōno, zungōno, dat. pl. gëbōn, salbōn, to anoint, suohtōs(t), thou soughtest, became in MHG. gëben, boten, hërzen, zungen, salben, suohtest.

Gen. dat. acc. sing., nom. acc. pl. zungūn became MHG. zungen.

$\$ 171$. The weakened e regularly disappeared in MHG.

I. After 1 and $\mathbf{r}$ in dissyllables with short stems, as ar (older are $=\mathrm{OHG}$. aro, eagle), acc. gen. dat. arn, beside name, namen; wol, older wole $=$ OHG. wola, well ( $\mathrm{adv}$.$) ;$ and similarly in gar, schar, milch (OHG. milih), zal, val, vil, kil, quill, gen. kil(e)s, dat. kil, nom. acc. pl. kil, dat. pl. kil(e)n ; bërn, to bear, stëln, to steal, swern, to swear, varn, to go, var, verst, vert, beside hœre, hœrest, hœret, \&c.

2. After 1 and $\mathbf{r}$ in trisyllabic and polysyllabic forms with long stems, as gen. pl. blinder(e), gen. sing. engel(e)s, nom. pl. engel(e), grœzer (OHG. grōziro), gen.pl. lember(e), gen. sing. lūter(e)s, tiufel(e)s, dat. pl. venster(e)n, wandelte (OHG. wandelōta), I wandered, wundern (OHG. wuntarōn), zwifeln (OHG. zwifalōn). After the analogy of forms with long stems it was dropped in forms with short stems, as $\mathrm{pl}$. nagel, vogel beside nagele, vogele; wider beside widere (OHG. widaro); grober beside grobere.

3. After nasals in the final syllable of trisyllabic forms with long stems, as dat. sing. blindem(e), guotem(e), liebem(e); gevangen(e), prisoner, pl. gevangen from ge. vangen-en through the intermediate stage *gevangenn; gen. heiden(e)s, pl. heiden(e). After the analogy of forms with long stems, it was dropped in forms with short stems, as dat. $\operatorname{disem}(e), \operatorname{grobem}(e), \operatorname{vadem}(e), \operatorname{gen} . \operatorname{vadem}(e) s$.

4. After a nasal before a following $t$ in forms with a short stem, as 3. sing. $\operatorname{man}(e) t$, won(e)t, $\operatorname{scham}(e) t, \operatorname{nim}(e) t$; pl. nëm(e)t, ye take; pret. won(e)te, scham(e)te.

Nore. - The e, when not preceded by a nasal, was sometimes dropped in verbal forms ending in $t$. This was especially the 
case in wirst, wirt older wirdest, wirdet ; siht, he sees, sëht, ye see, older sihet, sëhet ; and often in forms like gilt, vint, spricht, sticht beside giltet, vindet, sprichet, stichet.

5. In the unstressed forms of dissyllables, as adv. ane, abe, mite, obe beside the prepositions an, ab, mit, ob; dat. sing. dëme, wëme, ime beside đëm, wëm, im ; unde, and, wande, for, because, beside und (unt), wan(d); hërre, frouwe beside hër, frou before proper names and titles.

$\$ 172$. The vowel in suffixal and derivative syllables was generally weakened to e just as in the inflexional syllables, but in some suffixal and derivative syllables which had a secondary accent the vowel was not weakened to e. This was especially the case with derivatives in .ære (denoting nomina agentis), .inne, .inc (-ing), -linc (-ling), diminutives in -in and -lin, abstract nouns in -nisse (-nusse, -nüsse), -unge. In others the vowel fluctuated between the full vowel and e, as in -isch beside $\cdot$ esch; $\cdot$ ic (=OHG. .ag, and -ĭg) beside .ec; superlative of adjectives -ist (=OHG. .ist) beside $\cdot$ est (=OHG. .ōst); $\cdot$ sal beside $\cdot$ sel. Beside the full forms $\cdot 1$ ich, .rich occurred the shortened forms lich, rich. The OHG. endings of the present participle -anti, ·enti, -ōnti, .ēnti regularly became -ende, but ant occurs in a few old participles which had become nouns, as heilant, wigant, viant beside vient (vint). Examples are : gartenære, schepfære, schribære ; küne. ginne, vriundinne, wirtinne ; edelinc, muiedinc, unhappy man; hendelinc, glove, vingerlinc, ring; magedin, vin. gerīn, ring; kindelīn, vogelin ; hindernisse, vancnüsse, captivity, vinsternisse; bezzerunge, handelunge, mel. dunge; himelisch, irdisch, kindisch, beside -esch ; heilic (OHG. heilag), honic (OHG. honag, honig), künic (OHG. cuning, cunig), manic (OHG. manag), sælic (OHG. sālīg) beside -ec; oberist beside oberest; kumbersal, trüe. besal, wëhsal beside wëhsel; bitterlich, sicherlich, wislīch beside .lich; Dietrīch, Heinrīch, beside .rich. 
§ 173] NHG. Vowels of Unaccented Syllables

The suffixal syllables •al, -am, -an, .ar (\$ 165) regularly became -el, -em, -en, -er, as nagel, vogel, bodem, ëben, zeichen, acker, bitter, wunter.

\section{The New High German Period.}

\$173. From what has been said in $\$$ 170-2 it will be seen that, with few exceptions, the OHG. long and short vowels were weakened to $\mathrm{e}$ in unaccented syllables in MHG. Although the weakening took place in Middle earlier than in Upper German, it is a remarkable fact that the e remained more fully intact in Middle than in Upper German during the MHG. and early NHG. period. In this respect, as in many others, Middle German has played an important part in the retention of the e in $\mathrm{NHG}$. In Upper German it was dropped in final syllables from about the end of the fourteenth century. A considerable number of these Upper German forms occur in the early writings of Luther, but most of them were doubtless due to the printer. They occur rarely in his later works. The rule, as to the retention or dropping of the final e, as it appears in the last edition of Luther's Bible ( $\mathbf{I}_{542}$ ), agrees in general with NHG. usage. The final e, when immediately following the principal accent, has disappeared in the modern dialects of Upper Germany and the greater part of Middle Germany.

In late MHG. and early NHG. scholars, especially in Upper Germany, began to introduce a final e into forms which had formerly dropped it and into forms which previously had never had it. This was a kind of reaction against dialect usage, and at the same time an attempt to imitate the written language of Middle German. Examples of the introduction of final e into forms which did not previously have it are: acc. sing. boume, vriunde, jāre, burge; nom. acc. neut. pl. pfërde, kindere; imperative 
and pret. of strong verbs, as bite (wait), vande, schuofe, stuonde, \&c. This partly explains why the plural of many neuter nouns ends in e in NHG., as felle, jahre, pferde, \&c., and why the imperative sing. of many strong verbs ends in e, as schreibe, singe, rate. Pret. forms like fande, schufe have now disappeared from the literary language, but they were common in early NHG.

$\S 174$. The retention or rejection of the weakened e in medial and final syllables has been brought about by several important factors, the chief of which are :

I. Behaghel's Law (Germania, vol. xxiii, $264 \mathrm{ff}$.) whereby in trisyllabic and polysyllabic forms the weakened e was regularly dropped in the syllable which preceded or followed the one having the secondary accent. That is in forms of the type of $\perp \mathrm{e} \perp$ or $\angle \geq \mathrm{e}$. Traces of this law occur already in MHG., as boumgart beside boumgarte, mensche (OHG. mennisco), vischær beside vischære (OHG. fiscāri), gen. ābents beside ābendes, pret. wundert beside wunderte. There are numerous examples in medial syllables, as beste (OHG. bezzisto), gebærde (OHG. gibārida), superl. grœste (OHG. grōzisto), hērsen (OHG. hērisōn, to rule), schœnste (OHG. scōnisto), sælde (OHG. sālida, blessedness), zierde (OHG. ziarida, adornment). In early NHG. the law became general, and all forms which are not in harmony with it are analogical formations. Examples are: allerhand (M HG. allerhande), armut (MHG. armuote), atmung (MHG. ātemunge), elend (MHG. ellende), forderung (MHG. vorderunge), gärtner (MHG. gartenære), herzog (MHG. herzoge), königin (MHG. küne. ginne), krebs (MHG. krëbeze), lebend (MHG. lëbende), leichnam (MHG. līchnằme), am Montag beside tage, fremd (MHG. fremide), friedlich (MHG. fridelich), hemd (OHG. hemidi), jüngling (M HG. jungelinc), junker (M HG. junchērre), kebse (OHG. kebisa), königs (MHG. küniges), münze (OHG. muniza), stiicklein (MHG. stuckelinn); the 
\$ 174] NHG. Vowels of Unaccented Syllables 81

pret. of weak verbs, as lebte, legte, sagte $=$ MHG. lëbete, legete, sagete; kirchhofs beside hofes; regular forms are wirtshaus, amtsdiener, ghïckskind, landsmann, \&c., forms like tageszeit, landesherr, gotteshaus, \&c., have been influenced by the simplex tages, landes, gottes.

NoтE.-The $\mathbf{i}$ in bräutigam and nachtigall is due to the palatal $\mathbf{g}$.

In some words the NHG. uninflected forms have been remodelled on analogy with the inflected forms, as amt, gen. amtes (= MHG. ambetes), haupt, gen. hauptes (= M HG. houbetes), magd (MHG. maget, pl. magede), and similarly in dienst, fels, held, herbst, hirsch, nackt, obst, papst, and in the pp. of verbs, gelebt, gelegt, gesagt, \&c.

2. In adjectives and nouns : The nature of the consonant preceding the final e was also an important factor.

(a) If the consonant was a voiced explosive or voiced spirant, the final e generally remained, so as to preserve the voiced sound of the consonant in all forms; had the e been dropped the consonant would have become voiceless (§ 226), as öde (MHG. œde), träge (M HG. træge), trïbe (MHG. truiebe), weise (M HG. wise), and similarly in behende, blöde, böse, gelinde, gerade, herbe, leise, miide, schnöde, \&c., but gescheit, mild, schräg, wild = MHG. geschīde, milte, schræge, wilde.

ende (MHG. ende), erbe (MHG. erbe), gebilde ( $\mathrm{MHG}$. gebilde), and similarly in gebäude, gebinde, gebirge, gedränge, gefilde, gefolge, gelände, geleise, gehänge, gemiüse, gepräge, gesinde, getreide, gewebe, gewerbe, gewölbe, \&c., but bild (OHG. bilidi) which passed into the er plurals (\$ 398).

(b) If the consonant was a voiceless explosive or voiceless spirant, a liquid or nasal, or if the preceding sound was a vowel, the final e was generally dropped, as spät (MHG. spæte), kiihl (M HG. küele), leer (MHG. lære), neu (MHG. niuwe), and similarly in bequem, bereit, dicht, diunn, dïrr, 
eng, fest, feucht, früh, gemäss, gemein, genehm, gering, grün, $j a ̈ h$, keusch, klein, kiihn, neu, rein, schön, schwer, still, streng, süss, teuer, zäh, \&c., but irre, and nütze, kirre beside nütz, kirr, with e retained because of their being chiefly used predicatively.

erz (MHG. erze), gebein (MHG. gebeine), gemüt (MHG. gemiiete), kinn (MHG. kinne), and similarly in antlitz, bett, flötz, gebiet, gebüsch, gedicht, gefährt, gefecht, gehirn, gehöft, gehölz, geleit, gelïst, gepäck, gerät, geräusch, gerüst, geschäft, geschenk, geschirr, geschlecht, geschrei, gesetz, gespann, gespenst, gestirn, gewächs, gewicht, glück, heer, heft, heu, hirn, kreuz, netz, ohr, öl, pfühl, reich, \&c., but gerippe which has been influenced by rippe.

3. Gender, sex, and the declension to which a noun originally belonged have also played an important factor.

(a) The final e has generally remained in the nom. of weak nouns denoting living objects, as affe, ahne, bote, bracke, bube, buhle, bürge, drache, erbe, falke, farre, ferge, finke, gatte, gefährte, geselle, hase, jude, knabe, knappe, laffe, laie, löwe, neffe, ochse, pathe, pfaffe, rabe, rappe, recke, riese, riide, scherge, schulze, schurke, senne, sklave, zeuge, beside the shortened forms in farr, fink, ochs, pfaff. The loss of the e in first, graf, herr, prinz is due to the proclitic use of these words before proper names.

Feminine nouns have generally preserved the final $e$, as gnade, haube, klage, liebe, nase, rede, reise, wiege, \&c., see (b) below. It has been added in bühne, che (MHG. e)), granne (MHG. gran), kehle (MHG. kë1), krähe, mähne (M HG. man, see § 377), mühle, schale (MHG. schal), sohle, waare, and a few others.

The final e has been added to form the neut. pl. of many old a.stems, except those ending in -el, -em, -en, -er, -chen, and -lein, as in brot, haar, jahr, pferd, ross, schaf, spiel, tier, tor, werk, \&c., see $\$ 356$.

(b) The old weak masculine nouns denoting inanimate 


\section{§ 175] NHG. Vowels of Unaccented Syllables 83}

objects have nearly all either dropped the final e and then passed into the vocalic or mixed declension ; or have taken the $\mathbf{n}$ from the oblique cases and then gone over into the vocalic declension, cp. on the one hand April (MHG. aprille), blitz, brei, gemahl, keim, kern, lenz, Mai, März, schmerz, stern, and on the other hand balken (MHG. balke), bogen, brunnen, galgen, garten, husten, knochen, magen, rahmen, schinken, tropfen, see § 383.

The final e has been dropped in several feminine nouns, especially after $\mathrm{t}$, as acht, furcht, hut (heed), maut, rast, rost, schlacht, wacht; feier, form, huld, mark, mauer, pein, scheuer, schmach, zier.

$\$ 175$. Final -el, -em, -en, -er have become vocalic $1, \mathrm{~m}$, $\mathrm{n}, \mathrm{r}$, although the $\mathrm{e}$ is retained in writing, as handel (= hand1), atem, degen, denken, leben, eber. When the consonant preceding vocalic $\mathbf{n}$ is a labial or guttural, educated people often assimilate the two sounds, as denky, lebm, but this is not considered 'fine'. 'The e is omitted in writing when the vocalic $\mathbf{n}$ is preceded by a liquid, as handeln, edeln, wandern, vätern, heitern, but retained when preceded by $\mathrm{n}$, as rechnen, trocknen.

The normal development of -ele, eme, ene, ere is vocalic $1, \mathrm{~m}, \mathrm{n}, \mathrm{r}(\S 171)$ which have remained vocalic before consonants, as gen. deckels, ebers; handelst, handelt, wanderst, wandert; edelste, trockenste, heiterste. They have also remained vocalic when final, as fem. sing. nadel, feder; dat. sing. and nom. pl. of masc. and neuter nouns, deckel, engel, segel, degen, eber, messer. But in verbs and adjectives the second $e$ has been restored after the analogy of forms where it was regular, as in ich binde, rufe, sage; gen. blindes, gutes, pl. blinde, gute, \&c. Vocalic $1, \mathrm{~m}, \mathrm{n}, \mathrm{r}$ have then become consonantal, as ich handle, atme, segne, wandre; edles, edle, trocknes, trockne, heitres, heitre, \&c.

The regular forms have often been disturbed by ana. logical formations, as ich handele, wandere after the analogy 
of handelt, wandert; similarly edlen, hettren after edles, heitres; cdeler, heiterer, edeles, heiteres, edelen, heiteren, edele, heitere after edelste, heiterste and blinder, blindes, blinden, blinde.

$\S 176$. The following paragraphs merely contain an outline of the history of the vowels of unaccented syllables, the rest will be found in the Accidence.

$\S 177$. Dative: The ending e of the dat. singular of nouns and adjectives was dropped after el, em, en, er already in MHG. (\$ 171). It has been dropped in NHG. (partly also in MHG.) in diminutives in .chen and -lein. It is generally dropped in nouns ending in a vowel (dem Schnee, \&c.), and in those ending in -and, -at, .end, .icht, .ing, -ling, -rich, .sal, -tum (\$ 174), likewise in combinations without the article, as von tag zu tag, zu fuss, mit dank erhalten, \&c.

In dissyllabic forms NHG. fluctuates between the rejection and retention of e. When the one and when the other form is used depends chiefly upon sentence rhythm. In the colloquial language it is dropped more frequently than in the written language.

$\S 178$. Genitive : The presence or absence of the $\mathbf{e}$ in the gen. singular follows the same rule as for the dat. sing., except that the e is retained after sibilants (tisches, \&c.). It is always retained in adjectives, but is omitted in adverbial genitives, as bereits, längs, links, rechts, \&c.

$\S 179$. Nom. plural : Nouns and adjectives ending in •el, .em, .en, .er dropped the e already in MHG. (§ 171). NHG. has preserved this rule in the nouns, but e has been restored in the adjectives after the analogy of those adjectives whose uninflected forms did not end in a liquid or nasal, as pl. andere (MHG. ander), edle (MHG. edel) after the analogy of blinde. Masculine and feminine nouns, and the adjectives have retained the e. And many old neuter a.stems have added it ( $\$ 173)$.

$\S 180$. Dative plural: The ending en has become vocalic 
§ 18r] NHG. Vowels of Unaccented Syllables 85

$\mathbf{n}$, written en (but written $\mathbf{n}$ after liquids): When the sing. ends in en the dat. pl. ending had disappeared in MHG. $(\$ 171,3)$, but in adjectives it has been restored in NHG. (\$ 182).

$\$ 181$. Verbs: e has disappeared in the second and third pers. sing. of the present of strong verbs, as schreibst (MHG. schribest), schreibt (MHG. schribet), nimmst (MHG. nimest), nimmt (MHG. nimet), but it is often retained in the second pers. after a voiceless sibilant, as issest, drischest. When the stem ends in $\mathbf{d}$ or $\mathrm{t}$, the $\mathrm{e}$ is regularly dropped in those verbs which have umlaut or have preserved the old interchange between $i$ and $e$ in the present, as trittst, tritt: treten, wirst, wird: werden, giltst, gill : gelten, hältst, hält : halten, \&c., but bittest, bittet ; leidest, leidet; bindest, bindet.

In the weak verbs the e has regularly been dropped in the second and third pers. of the present, except when the stem ends in $\mathrm{d}$ or $\mathbf{t}$, as lebst, lebt; sagst, sagt, \&c., but redest, redet; betest, betet. In the pp. and the whole of the pret. of weak verbs the e has been dropped before the $\mathbf{t}$ except in those verbs whose stems end in $\mathbf{d}$ or $\mathbf{t}$, as lebte (MHG. lëbete), lebtest (MHG. 1ëbetest), gelebt (MHG. gelëbet), \&c., but redete, redetest, geredet.

With the exception of sein and tun, verbal forms ending in $\mathbf{n}$, which were monosyllabic in early NHG. (partly also in MHG.), have now become dissyllabic after the analogy of the other verbs, as freuen, gehen, mühen, säen, stehen, wehen.

After the analogy of the other verbs, a final e has been added in the first pers. sing. pres. indic. of those verbs which regularly dropped the e in MHG. (§ 171), as fahre (MHG. var), mahle (MHG. mal), \&c. After the analogy of the weak verbs, a final $e$ has been added in the imperative second sing. of strong verbs, except kommen, lassen, and in those strong verbs which still preserve the old interchange between $\mathbf{i}$ and $\mathbf{e}$ in the present (nimm: nehmen), as bleibe, 
biete, binde, rate. The same thing occurred occasionally also in MHG. (\$ 173).

$\S 182$. $e$ has been dropped before $t$ in the superlative of adjectives (except after dentals and sibilants), as kleinste, jüngste, höchste, but älteste, süsseste. In beste (MHG. beste, OHG. bezzisto) and grösste (MHG. grœste) it was dropped in MHG.

Usage varies after vowels, as genauste, frohste beside genaueste, froheste. The $\mathbf{e}$ is always dropped in derivative adjectives, as härteste beside verhärtetste.

e has been added in those adjectives which regularly dropped it in the inflected forms in MHG. (\$175), as MHG. nom. sing. and pl. masc. ander, NHG. sing. andrer, $\mathrm{pl}$. andere; gen. MHG. anders, NHG. anderes. The MHG. shorter forms exist beside the NHG. longer forms with differentiated meanings in anders beside anderes, enzeln beside einzelnen, eltern beside älteren.

$\S 183$. The suffixal and derivative syllables which preserved the full vowel in MHG. also have it in NHG., as königin, jüngling, finsternis, forderung, freundlich, Friedrich, fräulein.

Where e and i fluctuated in MHG. (§ 172), NHG. has i before palatal $\mathrm{g}$, ch, sch, as selig, kräftig, rettig, töricht, kindisch, \&c.

$\S \mathbf{1 8 4}$. The weakened vowel was sometimes written a in the fourteenth and fifteenth centuries ( $\$ 170)$. This accounts for the a in NHG. balsam (MHG. balsam, balsem), bisam (MHG. bisem), bräutigam (MHG. briutegome), brosam, brosame (cp. MHG. brōsem, brōsme), èdam (M HG. eidem), heimat (MHG. heimōt, -uot), monat (MHG. mānōt), nachbar (MHG. nāchgebūre), weiland (MHG. wilen(t)), fruchtbar (M HG. vruhtbære), and similarly in other adjectives ending in bar. wigand (MHG. wigant) was introduced into NHG. from MHG. in the eighteenth century. 
§ 185] Ablaut (Vowel Gradation)

\section{CHAPTER IX}

\section{ABLAUT (VOWEL GRADATION)}

$\S 185$. By ablaut is meant the gradation of vowels both in stem and suffix, which was caused by the primitive IndoGermanic system of accentuation. See § 23.

The vowels vary within certain series of related vowels, called ablaut-series. In OHG., to which this chapter will chiefly be limited, there are six such series, which appear most clearly in the stem forms of strong verbs. For the changes, which the vowels constituting the six series underwent in MHG. and NHG., the student should consult the various classes of strong verbs (\$\$ 490-519). Four stem-forms are to be distinguished in an OHG. strong verb which has vowel gradation as the characteristic mark of its different stems : $-(\mathbf{I})$ the present stem, to which belong all the forms of the present, (2) the stem of the first or third pers. pret. singular, (3) the stem of the pret. plural, to which belong the second pers. pret. singular and the whole of the pret. subjunctive, (4) the stem of the past participle.

By arranging the vowels according to these four stems we arrive at the following system :-

\begin{tabular}{|c|c|c|c|c|}
\hline & i. & ii. & iii. & iv. \\
\hline I. & $\overline{\mathbf{i}}$ & $\mathrm{ei}, \overline{\mathrm{e}}$ & i & i \\
\hline II. & eo(io) & ou, o & $\mathbf{u}$ & 0 \\
\hline III. & $\mathrm{i}, \ddot{\mathrm{e}}$ & a & $\mathbf{u}$ & $\mathbf{u}, \mathbf{o}$ \\
\hline IV. & $\ddot{\mathrm{e}}$ & $a$ & $\overline{\mathbf{a}}$ & 0 \\
\hline V. & $\ddot{e}$ & a! & $\overline{\mathbf{a}}$ & $\ddot{\mathrm{e}}$ \\
\hline VI. & $a$ & uo & uo & a \\
\hline
\end{tabular}

NoTE, -1 . On the difference between ei and $\bar{e}$, see $\$ 75$; ou and $\bar{o}, \S 76$; and in Series III $\mathbf{i}$ and $\ddot{e}, \S 55 ; \mathbf{u}$ and $o, \S 57$.

2. Strong verbs belonging to Series II have iu in the indicative pres. singular ( $\$ 77)$; and strong verbs belonging to Series 
III-V with $\ddot{e}$ in the infinitive have $\mathbf{i}$ in the indicative pres. singular (\$§ 55, 62).

But although the series of vowels is seen most clearly in the stem forms of strong verbs, the learner must not assume that ablaut occurs in strong verbs only. Every syllable of every word of whatever part of speech contains some form of ablaut. As for example, the sonantal elements in the following stem-syllables stand in ablaut relation to each other :-

heiz, heiss : hizza, hitze; lēren, lehren: lirnēn (lërnēn), lernen, list; wizago, weissager: weiz, weiss: wizzi, witz, giwis, gewiss.

biotan, bieten: boto, bote, gibot, gebot, butil, biittel; fliozan, fliessen : flōz, floss : fluz, fluss; liob, lieb : gilouben, glauben: lobōn, loben, gilubida, gelïbde; ziohan, ziehen : zoum, zaum : herizogo, herzog, zug.

bintan, binden : bant, band: MHG. bunt, bund ; trinkan, trinken : trank, trank: MHG. trunc, trunk.

bëran, gebären: barn (child): bāra, bahre, gibārida, gebärde: giburt, geburt; nëman, nehmen: gināmi, angenehm: firnunft, vernunft; sprëchan, sprechen: sprācha, sprache: MHG. spruch, spruch.

gëba (gift): MHG. gābe, gabe : gift, mit-gift.

faran, fahren, fart, fahrt: furt, fuhrt; hano, hahn: huon, huhn.

$\S 186$. In this paragraph will be given the prim. Germanic and Gothic equivalents of the above six ablautseries, with one or two illustrations from OHG. For further examples see the various classes of strong verbs, \$ 490-519.

$\begin{array}{rlllll}\text { Prim. Germ. } & \mathbf{i} & \text { I. } & & & \\ \text { Gothic } & \text { ei } & & \text { ai } & \mathbf{i} & \mathbf{i} \\ \text { OHG. } & \text { stigan, to ascend } & \text { steig } & \text { stigum } & \text { sistigan } \\ & \text { dihan, to thrive } & \text { dēh } & \text { digum } & \text { gidigan }\end{array}$

Note. -Cp. the parallel Greek series $\pi \epsilon^{i} \theta \omega: \pi \dot{\epsilon} \pi \theta_{\imath} \theta a: \ddot{\epsilon} \pi \iota \theta 0 \nu$. 
II.

$\begin{array}{rlccc}\text { Prim. Germ. } & \text { eu } & \text { au } & \mathbf{u} & 0 \\ \text { Gothic } & \text { iu } & \text { áu } & \mathbf{u} & \mathbf{u} \\ \text { OHG. } & \text { liogan, to lie } & \text { loug } & \text { lugum } & \text { gilogan } \\ & \text { biotan, to offer } & \text { bōt } & \text { butum } & \text { gibotan }\end{array}$

Cp. the parallel Greek series $\epsilon^{\lambda} \lambda \epsilon^{\prime}(\theta) \sigma o \mu a \iota$ (fut.): $\epsilon^{\prime} \lambda \hat{\eta}^{\prime} \lambda o v \theta a$ : $\ddot{\eta} \lambda v \theta 0 \nu$.

$\begin{array}{llccc}\text { Prim. Germ. } & \text { e, } \mathbf{i} & \mathbf{a} & \mathbf{u} & \mathbf{u}, \mathbf{o} \\ \text { Gothic } & \mathbf{i} & \mathbf{a} & \mathbf{u} & \mathbf{u} \\ \text { OHG. hëlfan, to help } & \text { half } & \text { hulfum } & \text { giholfan } \\ \text { bintan, to bind } & \text { bant } & \text { buntum } & \text { gibuntan }\end{array}$

NotE.-I. To this series belong all strong verbs having a medial nasal or liquid + consonant, and a few others in which the vowel is followed by two consonants other than a nasal or liquid + consonant.

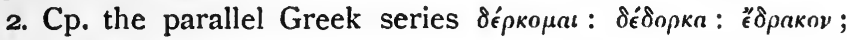
$\pi \dot{\epsilon} \mu \pi \omega:$ : $\pi \dot{\epsilon} \pi \tilde{\mu} \phi a$.

Prim. Germ. e

Gothic

OHG. nëman, to take sprëchan, to speak sprah sprāchum gisprochan

nam nāmum ginoman
IV.

a $\bar{æ} \quad$ o

a $\overline{\mathrm{e}}$

t1

Notr.---I. To this series belong all strong verbs whose stems end in a single liquid or nasal, and a few others.

2. Cp. the parallel Greek series $\mu \epsilon^{\prime} \nu \omega: \mu o v^{\prime}: \mu i^{\prime}-\mu \nu \omega ; \delta \epsilon^{\prime} \rho \omega: \delta o p a ́$ :

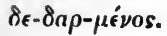

$\begin{array}{cc}\text { Prim. Germ. } & \text { e } \\ \text { Gothic } & \mathbf{i}\end{array}$

V.

$\mathrm{OHG}$. gëban, to give a

a

gab gābum gigëban

Note.-I. To this series belong all strong verbs having ë in the present, and ending in other consonants than those in Classes III and IV.

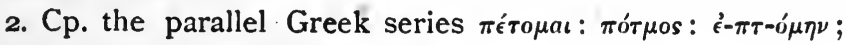

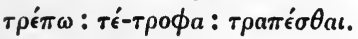


VI.

$\begin{array}{ccccc}\text { Prim. Germ. } & \text { a } & \overline{0} & \overline{0} & \text { a } \\ \text { Gothic } & \text { a } & \overline{0} & \overline{0} & a \\ \text { OHG. } & \text { faran, to go } & \text { fuor } & \text { fuorum } & \text { gifaran }\end{array}$

$\$ 187$. Class VII of strong verbs embracing the old reduplicated verbs (\$\$ 513-9) has been omitted from the ablaut-series, because the exact relation in which the vowel of the present stands to that of the preterite has not yet been satisfactorily explained. The old phases of ablaut have been preserved in the present and preterite of a few Gothic verbs, as lētan, to let, laílōt, laílōtum, lētans; saian, to sow, saísō, saí.sō.um, saians.

$\$ 188$. The ablaut-series as given in $\$ \mathbf{1 8 6}$ have for practical reasons been limited to the phases of ablaut as they appear in the various classes of strong verbs. From an Indo-Germanic point of view, the series I-V belong to one and the same series, generally called the e-series, which underwent in primitive Germanic various modifications upon clearly defined lines. What is called the sixth ablaut-series in the Germanic languages is really a mixture of several original series, owing to several Indg. vowelsounds having fallen together in prim. Germanic, thus the a, which occurs in the present and past participle, corresponds to three Indg. vowels, viz. a (\$ 31), o (\$ 34), and a (§ 36); and the $\bar{o}$ in the preterite corresponds to Indg. $\bar{a}$ (§37) and Indg. $\bar{o}(\S 40)$. For the phases of ablaut which do not occur in the various parts of strong verbs; and for traces of ablaut-series other than those given above, the student should consult Brugmann's Kurze vergleichende Grammatik der indogermanischen Sprachen, pp. 138-50. 


\section{CHAPTER $\mathrm{X}$}

THE FIRST SOUND-SHIFTING, VERNER'S LAW, AND OTHER CONSONANT CHANGES WHICH TOOK PLACE IN THE PRIMITIVE GERMANIC LANGUAGE

\$ 189. The first sound-shifting, popularly called Grimm's Law, refers to the changes which the Indo-Germanic explosives underwent in the period of the Germanic primitive community, i. e. before the Germanic parent language became differentiated into the separate Germanic languages:-Gothic, O. Norse, O. English, O. Frisian, O. Saxon (= O. Low German), O. Low Franconian (O. Dutch), and O. High German.

$\$ 100$. The Indo-Germanic parent language had the following system of consonants :-

Labial. Dental. Palatal. Velar.

离।

tenues mediae

tenues aspiratae mediae aspiratae bh

Spirants $\left\{\begin{array}{l}\text { voiceless } \\ \text { voiced }\end{array}\right.$

Nasals

Liquids

Semivowels

p
b
ph
bh

m

$\mathbf{w}(\mathbf{u})$

$\mathrm{t}$
$\mathrm{d}$
$\mathrm{th}$
$\mathrm{dh}$

s

z j

n

$1, \mathrm{r}$

ń

$\eta$

NotE.--I. Explosives are consonants which are formed with complete closure of the mouth passage, and may be pronounced with or without voice, i.e. with or without the vocal cords being set in action; in the former case they are said to be voiced (e.g. the mediae), and in the latter voiceless 
(e.g. the tenues). The aspirates are pronounced like the simple tenues and mediae followed by an $h$, like the AngloIrish pronunciation of $t$ in tell.

The palatal explosives are formed by the front or middle of the tongue and the roof of the mouth (hard palate), like $\mathbf{g}, \mathbf{k}$ (c) in English get, good, kid, could ; whereas the velars are formed by the root of the tongue and the soft palate (velum). The latter do not occur in English, but are common in Hebrew, and are often heard in the Swiss pronunciation of literary German. In the parent Indo-Germanic language there were two kinds of velars, viz. pure velars and velars with lip rounding. The pure velars fell together with the Indg. palatals in Germanic, Latin, Greek, and Keltic, but were kept apart in the Aryan and Baltic-Slavonic languages. The velars with lip rounding appear in the Germanic languages partly with and partly without labialization, see $\S 198$. The palatal and velar nasals only occurred before their corresponding explosives, ńk, ńg ; yq, yg, \&c.

2. Spirants are consonants formed by the mouth passage being narrowed at one spot in such a manner that the outgoing breath gives rise to a frictional sound at the narrowed part.

$z$ only occurred before voiced explosives, e. g. ${ }^{*}$ nizdos $=$ Lat. nïdus, Germ. nest ; *ozdos = Gr. ö Kos, Germ. ast.

j was like the widely spread North German pronunciation of $\mathbf{j}$ in $\mathbf{j a}$, not exactly like the $\mathbf{y}$ in English yes, which is generally pronounced without distinct friction. $\mathbf{j}$ occurred very rarely in the prim. Indo-Germanic language. In the Germanic, as in most other Indo-Germanic languages, the frictional element in this sound became reduced, which caused it to pass into the so-called semivowel.

3. The nasals and liquids had the functions both of vowels and consonants ( $\S 30)$.

4. The essential difference between the so-called semivowels and full vowels is that the latter always bear the stress (accent) of the syllable in which they occur, e. g. in English ców, stáin the first element of the diphthong is a vowel, the second a consonant; but in words like French rwá (written roi), bjếr (written bière), the first element of the diphthong is a consonant, the second a vowel. In consequence of this twofold 
function, a diphthong may be defined as the combination of a sonantal with a consonantal vowel. And it is called a falling or rising diphthong according as the stress is upon the first or second element. In this book the second element of diphthongs is written $\mathbf{i}, \mathbf{u}$ when the first element is the bearer of the stress, thus ai, áu, \&c., but when the second element has the stress the first element is written $\mathbf{j}, \mathbf{w}$, thus já, wá, \&c.

5. In the writing down of prim. Germanic forms the signs $\mathbf{p}$ (= th in Engl. thin), $d$ (= th in Engl. then), of (=a bilabial spirant, which may be pronounced like the $\mathbf{v}$ in Engl. vine), $\mathbf{z}$ ( $=\mathbf{g}$ often heard in German sagen), $\mathbf{x}$ (= NHG. ch).

$\$ 191$. In the following tables of the normal equivalents of the Indg. explosives in Latin, Greek, and the Germanic languages, Table I contains the Indg. tenues $\mathbf{p}, \mathbf{t}, \mathbf{k}$, the mediae $\mathbf{b}, \mathbf{d}, \mathbf{g}$, and the pure velars $\mathbf{q}, \mathbf{g}$. 'Table II contains the Indg. mediae aspiratae and the velars $q, g$ with labialization. The equivalents in the Germanic languages do not contain the changes caused by Verner's law, \&c. The East Franconian dialect is taken as the normal for OHG.

The following points should be noticed :-

(I) The Indg. tenues $\mathbf{p}, \mathbf{t}, \mathbf{k}$ and the mediae $\mathbf{b}, \mathrm{d}, \mathrm{g}$ generally remained unchanged in Latin and Greek.

(2) The pure velars $(q, g)$ fell together with the palatals $\mathbf{k}, \mathbf{g}$ in Latin and Greek. They became $\mathbf{x}, \mathbf{k}$ in prim. Germanic, and thus fell together with the $x, k$ from Indg. $\mathbf{k}, \mathbf{g}$.

(3) The pure velar gh fell together with the original palatal gh in Latin and Greek.

(4) The Indg. mediae aspiratae became in prehistoric Latin and Greek tenues aspiratae, and thus fell together with the original tenues aspiratae.

(5) The Indg. tenues aspiratae became voiceless spirants in prim. Germanic, and thus fell together with the voice. less spirants from the Indg. tenues. 
(6) In Latin, Indg. q with labialization became qu, rarely c. $\mathbf{g}$ with labialization became $\mathbf{v}$ (but gu after $\mathbf{n}$, and $\mathbf{g}$ when the labialized element had been lost, as gravis $=\mathrm{Gr}$. Bapvis, heavy).

Indg. ph, bh became $\mathbf{f}$ initially and $\mathrm{b}$ medially.

Indg. th, dh became $f$ initially, $b$ medially before and after $\mathbf{r}$, before 1 and after $\mathbf{u}(\mathbf{w})$, in other cases $d$.

Indg. $\mathbf{k h}$, $\mathbf{g h}$ became $\mathbf{h}$ initially before and medially between vowels; $g$ before and after consonants, and $\mathbf{f}$ before $\mathbf{u}(\mathbf{w})$.

Indg. $\mathbf{q h}$, gh with labialization became $\mathbf{f}$ initially and $\mathbf{v}$ medially except that after $\mathbf{n}$ it became gu.

(7) In Greek, Indg. $q, g$ with labialization became $\pi, \beta$ before non-palatal vowels (except $\mathfrak{u}$ ) and before consonants (except Indg.j) ; $\tau, \delta$ before palatal vowels; and $k, \gamma$ before and after $\mathfrak{u}$.

Indg. ph, bh became $\phi$; th, $\mathrm{dh}$ became $\theta$; and $\mathrm{kh}$, gh became $x$.

Indg. qh, gh with labialization became $\phi$ before nonpalatal vowels (except $\mathbf{u}$ ) and before consonants (except Indg. $\mathrm{j}$ ) ; $\theta$ before palatal vowels; and $\mathrm{x}$ before and after $\mathbf{u}$.

(8) When two consecutive syllables would begin with aspirates, the first was de-aspirated in prehistoric times in Sanskrit and Greek, as Skr. bándhanam, a binding, Goth. OE. bindan, OHG. bintan, to bind; Skr. bódhati, he learns, is awake, Gr. $\pi \epsilon \dot{\theta} \theta \epsilon \tau a l$, he asks, inquires, Goth. ana. biudan, to bid, OHG. biotan, to offer, root bheudh-; Gr. каv $\theta \dot{v} \lambda \eta$, a swelling, OE. OHG. gund, matter, pus; Gr. $\theta \rho i \xi$,

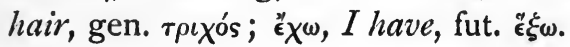


§ 19I]

The First Sound-shifting

TABLE I.

\begin{tabular}{|c|c|c|c|c|c|c|}
\hline Indg. & Latin & Greek & $\begin{array}{l}\text { P. Ger- } \\
\text { manic }\end{array}$ & Gothic & $\mathrm{OE}$. & OHG. \\
\hline p & p & $\pi$ & f & f & f & f \\
\hline$t$ & $\mathrm{t}$ & $\tau$ & p & p & p & d \\
\hline $\mathrm{k}, \mathrm{q}$ & c & $\kappa$ & $x$ & $h, x$ & $h, x$ & $h, x$ \\
\hline b & b & $\beta$ & $p$ & $p$ & $\mathbf{p}$ & $\mathrm{pf}, \mathrm{ff}$ \\
\hline $\mathrm{d}$ & d & $\delta$ & $t$ & $\mathbf{t}$ & $\mathbf{t}$ & $z, 33$ \\
\hline $\mathrm{g}, \boldsymbol{\alpha}$ & g & $\gamma$ & k & k & c & $\mathrm{k}, \mathrm{hh}$ \\
\hline
\end{tabular}

TABLE II.

\begin{tabular}{|c|c|c|c|c|c|c|}
\hline Indg. & Latin & Greek & \begin{tabular}{|} 
P. Ger- \\
manic
\end{tabular} & Gothic & $\mathrm{OE}$ & OHG. \\
\hline $\mathbf{q}^{W}$ & $q u, c$ & $\pi, \tau, k$ & $\mathrm{x}^{\mathrm{w}}, \mathrm{x}$ & $\mathrm{hv}, \mathrm{h}$ & $h w, h$ & (h)w, h \\
\hline$g^{\prime \prime}$ & $\mathrm{v}, \mathrm{gu}, \mathrm{g}$ & $\beta, \delta, \gamma$ & $\mathrm{kw}, \mathrm{k}$ & $q, k$ & $\mathrm{cw}, \mathrm{c}$ & $q u ; k, h h$ \\
\hline bh & $\mathrm{f}, \mathrm{b}$ & $\phi$ & $b, b$ & $\mathrm{~b}, \mathrm{~b}$ & $b, f$ & b \\
\hline $\mathrm{dh}$ & $f, b, d$ & $\theta$ & d, d & d, $\mathbb{d}$ & d & $\mathrm{t}$ \\
\hline$g h$ & $h, g, f$ & $x$ & g, 3 & $\mathrm{~g}, 3$ & $\mathrm{~g}, 3$ & $g$ \\
\hline gh & $f, v, g u$ & $\phi, \theta, x$ & $3 w, 3, w$ & $3, w$ & $g, 3, w$ & $\mathrm{~g}, \mathrm{w}$ \\
\hline
\end{tabular}


$\S$ 192. The Indg. tenues $\mathbf{p}, \mathbf{t}, \mathbf{k}, \mathbf{q}$ became in prim. Germanic the voiceless spirants $f, p, x, x(x w)$.

p >f. Lat. pēs, Gr. moús, Goth. fōtus, OE. fōt, OHG. fuoz, foot ; Lat. piscis, Goth. fisks, OE. fisc, OHG. fisk, fish; Lat. nepos, OE. nefa, OHG. nëfo, nephew.

$\mathrm{t}>$ p. Lat. tu, Gr. Doric $\tau \dot{v}$, Goth. pu, OE. pū, OHG. dī, thou; Lat. trēs, Gr. $\tau \rho \in \hat{i} s, \mathrm{OE}$. prī, OHG. drī, three; Lat. vertō, I turn, Goth. waírpan, OE. weorðan, OHG. wërdan, to become ; Lat. frāter, Goth. brōpar, OE. brōðor, OHG. bruoder, brother.

$\mathrm{k}>\mathrm{x}$. Lat. canis, Gr. $\kappa \dot{\omega} \omega v$, Goth. hunds, OE. hund, OHG. hunt, hound, dog; Lat. cor (gen. cordis), Gr. карбі́ā, Goth. haírtō, OE. heorte, OHG. hërza, heart;

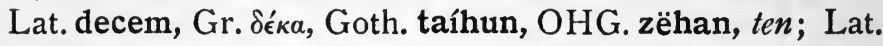
dūcō, I lead, Goth. tiuhan, OHG. ziohan, to draw, lead.

$\mathrm{q}>\mathrm{x}(\mathrm{xw})$. Lat. capiō, I take, Goth. hafjan, OE. hebban, OHG. heffen, to raise; Lat. vincō, I conquer, Goth. weihan, OHG. wihan, to fight.

Lat. quis, Gr. ris, Goth. hras, OE. hwā, OHG. hwër, wër, who? ; Lat. linquō, Gr. $\lambda \epsilon i n \pi \omega$, I leave, Goth. leihan, OHG. lihan, to lend.

Note. - I. The Indg. tenues remained unshifted in the combinations $\mathbf{s}+$ tenuis.

sp. Lat. spuere, Goth. speiwan, OE. OHG. spiwan, to vomit; Lat. con-spiciō, I look at, OHG. spëhōn, to spy.

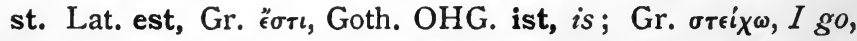
Lat. vestigium, footstep, Goth. steigan, $\mathrm{OE}$. OHG. stigan, to ascend.

sk. Gr. $\sigma \kappa \iota \grave{a}$, shadow, Goth. skeinan, OE. OHG. scinan, to shine; Lat. piscis, Goth. fisks, OE. fisc, OHG. fisk, fish.

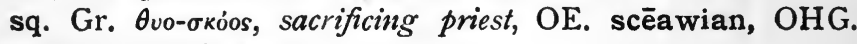
scouwōn, to look, view.

2. The $t$ also remained unshifted in the Indg. combinations pt, kt, qt.

pt $>$ ft. Gr. $k \lambda \dot{\epsilon} \pi \tau \eta s$, Goth. hliftus, thief; Lat. neptis, granddaughter, niece, OE. OHG. nift, niece. 
kt > Xt. Lat. octō, Gr. ỏkŕ, Goth. ahtáu, OE. eahta, OHG.

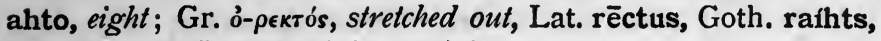
$\mathrm{OE}$. riht, OHG. rëht, right, straight.

qt $>$ xt. Gen. sing. Lat. noctis, Gr. vvкrós, nom. Goth. nahts, OE. neaht, OHG. naht, night.

$\S 193$. The Indg. mediae $b, d, g, g$ became the tenues $\mathrm{p}, \mathrm{t}, \mathrm{k}, \mathrm{k}(\mathrm{kw})$.

b $>$ p. O. Bulgarian slabŭ, slack, weak, Goth. slēpan, OE. slēpan, OHG. slāfan, to sleep; Lithuanian dubùs, Goth. diups, OE. dēop, OHG. tiof, deep. b was a rare sound in the parent language.

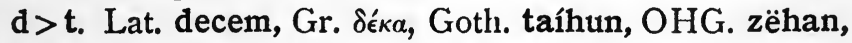
ten; Lat. dūcō, I lead, Goth. tiuhan, OHG. ziohan, to draw, lead; Lat. vidēre, to see, Goth. OE. witan, OHG. wizzan, to know; Lat. edere, Goth. itan, OE. etan, OHG. ëzzan, to eat.

g $>$ k. Lat. genu, Gr. yóvv, Goth. kniu, OE. cnēo, OHG. knio, knee; Lat. gustō, I taste, Gr. $\gamma \in v ́ \omega$, I let taste, Goth. kiusan, OE. cēosan, OHG. kiosan, to choose; Lat. egō, Gr. '̇ं'́, Goth. ik, OE. ic, OHG. ih, I; Lat. ager, Gr. ảypós, Goth. akrs, field, acre.

$\mathrm{g}>\mathrm{k}(\mathrm{kw})$. Lat. gelu, frost, Goth. kalds, OE. ceald, OHG. kalt, cold; Lat. augēre, Goth. áukan, OHG. ouhhōn, to add, increase; Lat. jugum, Gr. కvyóv, Goth. juk, OHG. joh, yoke.

Gr. Bios from *gīwos, life, Lat. vīvos from *gwìwos, Goth. qius, OE. cwicu, OHG. quëc, quick, alive; Lat. veniō from * ${ }^{*}$ wemjō, I come, Gr. $\beta a i v \omega$ from ${ }^{*} \beta a v j \omega$ older ${ }^{*} \beta a \mu j \omega=$ Indg. *gmjō, I go, Goth. qiman, OHG. quëman, to come.

$\$ 194$. The Indg. tenues aspiratae became voiceless spirants in prim. Germanic, and thus fell together with and underwent all further changes in common with the voiceless spirants which arose from the Indg. tenues (§ 192), the latter having also passed through the inter- 
mediate stage of tenues aspiratae before they became spirants. The tenues aspiratae were, however, of so rare occurrence in the prim. Indg. Germanic language that two or three examples must suffice for the purposes of this book :-Skr. root sphal., run violently against, $\mathrm{OE}$. feallan, OHG. fallan, to fall ; Gr. $\dot{a}-\sigma \kappa \eta \theta \dot{\eta}$ s, unhurt, Goth. skapjan, OHG. skadōn, to hurt, injure; Gr. $\sigma x i \xi \omega$, I split, Goth.

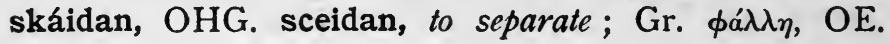
hwæl, OHG. (h)wal, whale.

\$195. The Indg. mediae aspiratae probably became first of all the voiced spirants $b, d, z, z(w)$. These sounds underwent the following changes during the prim. Germanic period:- $\mathbf{b}$, đ initially, and $\mathbf{b}$, đ, $\mathbf{z}$ medially after their corresponding nasals, became the voiced explosives b, $d, g$, as

b. Goth. baíran, OE. OHG. beran, to bear, Skr. bhá. rāmi, Gr. ф́́ $\rho \omega$, Lat. ferō, I bear; Goth. brōpar, OE. brōđor, OHG. bruoder, Skr. bhrătar., Lat. frāter, brother.

OE, comb, OHG. camb, comb, Skr. jámbhas, tooth, Gr. ró $\mu$ фos, bolt, nail, prim. form *gombhos.

d. Goth. dags, OE. dæg, OHG. tag, day, Skr. nidāghás, older *ni-dhāghás, hot season, summer, Indg. form *dhoghos ; OE. dǣd, OHG. tāt, deed, related to Gr. $\theta \dot{\eta}-\sigma \omega$, I shall place, Skr. dhăma, law, dwelling-place, root dhē., put, place.

Goth. OE. bindan, OHG. bintan, to bind, Skr. bándh. anam, a binding, cp. Gr. $\pi \epsilon \nu \theta \epsilon$ ós, father-in-law, Lat. offendimentum, chin-cloth, root bhendh-

g. Goth. aggwus, OHG. engi, narrow, cp. Lat. angō, Gr. ä $\gamma \chi^{\omega}, I$ press tight, root angh. ; Goth. laggs, OE. long, OHG. lang, Lat. longus, long.

$\$ 1$ 196. b, đ, 3 remained in other positions, and their further development belongs to the history of the separate languages. See $\$ \S 212,217-8$. 
$\S 197$. Various theories have been propounded as to the chronological order in which the Indg. tenues, tenues aspiratae, mediae, and mediae aspiratae, were changed by the first sound-shifting in prim. Germanic. But not one of these theories is satisfactory. Only so much is certain that at the time when the Indg. mediae became tenues the Indg. tenues must have been on the way to becoming voiceless spirants, otherwise the two sets of sounds would have fallen together.

$\S 198$. We have already seen ( $\$ 191)$ that the parent Indg. language contained two series of velars: (I) pure velars which never had labialization. These velars fell together with the palatals in the Germanic, Latin, Greek, and Keltic languages, but were kept apart in the Aryan and Baltic-Slavonic languages. (2) Velars with labialization. These velars appear in the Germanic languages partly with and partly without labialization ; in the latter case they fell together with prim. Germanic $x, k, z$ which arose from Indg. $\mathbf{k , ~ g , ~ g h . ~ T h e ~ m o s t ~ c o m m o n l y ~ a c c e p t e d ~}$ theory is that the Indg. labialized velars q, $g$, gh regularly became $x, \mathbf{k}, \mathbf{z}$ in prim. Germanic before Indg. $\overline{\mathbf{u}}, \overline{\mathbf{o}}, \mathbf{o}$

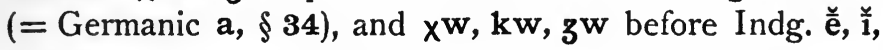
ə, $\mathbf{a}, \overline{\mathbf{a}}(=$ Germanic $\overline{\mathbf{o}}, \S \mathbf{3 7})$; and that then the law became greatly obscured during the prim. Germanic period through form-transference and levelling out in various directions, as Goth. qam, OHG. quam, prim. form *goma, I came, for Goth. OHG. *kam after the analogy of Goth. qima, OHG. quimu, original form * gemō, I come; Goth. huas, who?, Indg. *qos, for * has after the analogy of the gen. his = Indg. *qeso, \&c.

NotE.-In several words the Indg. velars, when preceded or followed by a $\mathbf{w}$ or another labial in the same word, appear in the Germanic languages as labials by assimilation. The most important examples are :-Goth. wulfs, OHG. wolf $=$ Gr. $\lambda$ íkos for ${ }^{*}$ F $\lambda$ úkos, prim. form *wlqos, cp. Skr. víkas, wolf; Goth. 
fidwōr, OE. fēower (but fyper-fēte, four-footed), OHG. fior, prim. form *qetwóres, cp. Lithuanian keturì, Lat. quattuor, Gr. т́㇒́ $\sigma a \rho \epsilon s$, Skr. catvắras, four; Goth. fimf, OHG. fimf, finf,

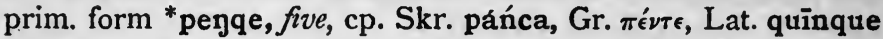
(for *pinque); OHG. wulpa, she-wolf, from *wulbi, prim. form *wlqí, cp. Skr. vrkí ; Goth. waírpan, OHG. wërfan, to throw, cp. O. Bulgarian vrĭgą, I throw ; OE. swāpan, OHG. sweifan, to swing, cp. Lithuanian swaikstù, I become dizzy.

\section{VERNER'S LAW.}

\$199. After the completion of the first sound-shifting, and while the principal accent was not yet confined to the root-syllable, a uniform, interchange took place between the voiceless and voiced spirants, which may be thus stated:-

The medial or final spirants $f, p, x, x w, s$ regularly became $\mathbf{b}, \mathbf{A}, \mathbf{z}, \mathbf{z} \mathbf{w}, \mathbf{z}$ when the vowel next preceding them did not, according to the original Indg. system of accentuation, bear the principal accent of the word.

The $\mathbf{b}, \mathbf{A}, \mathbf{z}, \mathbf{z} \mathbf{w}$ which thus arose from Indg. $\mathrm{p}, \mathbf{t}, \mathbf{k}, \mathbf{q}$ underwent in the Germanic languages all further changes in common with the $\mathrm{b}, \mathrm{d}, \mathrm{z}, \mathrm{z}^{\mathrm{w}}$ from Indg. bh, dh, gh, gh.

Verner's law manifests itself most clearly in the various parts of strong verbs, where the infinitive, present participle, present tense, and preterite (properly perfect) singular had the principal accent on the root-syllable, but the indicative pret. plural, the pret. subjunctive (properly optative), and past participle had the principal accent on the ending, as prim. Germanic *wérpō $>\mathrm{OE}$. weorðe, I become= Skr. vártā.mi, I turn; pret. indic. 3. sing. ${ }^{*}$ wárpi $>\mathrm{OE}$. weard, he became = Skr. va.várta, has turned; pret. I. pers. pl. *wurđumí $>\mathrm{OE}$. *wurdum (wurdon is the 3. pers. pl. used for all persons) $=$ Skr. va-vrtima, we have turned; past participle *wurđana. $>$ OE. worden $=\mathrm{Skr}$. va.vrtāná.; OS. birid, OHG. birit $=\mathrm{Skr}$. bhárati, he 
bears; Goth. 2. sing. indic. passive baíraza = Skr. bhá. rasē ; Goth. baírand, OHG. bërant $=$ Skr. bháranti, they bear. Or to take examples from noun-forms, \&c., we have e.g. Skr. pitár., Gr. $\pi \alpha \tau \epsilon^{\prime} \rho-=$ prim. Germanic *fađer., Goth. fadar, OE. fæder, OHG. fater, father; Skr. çatám, Gr. é-karóv, Lat. centum = prim. Germanic * xunđóm, older *xumđóm, Goth. OE. hund, OHG. hunt, hundred; Gr.

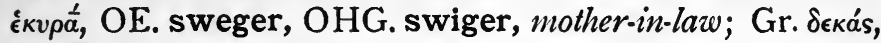
Goth. pl. tigjus, OE. -tig, OHG. -zug, decade.

The combinations sp, st, sk, ss, ft, fs, hs, and ht were not subject to this law.

Note. - The prim. Germanic system of accentuation was like that of Sanskrit, Greek, \&c., i. e. the principal accent could fall on any syllable; it was not until a later period of the prim. Germanic language that the principal accent was confined to the root-syllable. See $\$ 23$.

From what has been said above it follows that the inter. changing pairs of consonants due to Verner's law are : $\mathbf{f}-\mathbf{b}, \mathbf{p}-\mathbf{d}, \mathbf{s}-\mathbf{z}, \mathbf{x}-\mathbf{3}, \mathbf{x w}-\mathbf{z w}$. In the West Germanic languages $\mathbf{z}$ became $\mathbf{r}$ medially and was dropped finally. It is best to defer giving many examples of Verner's law in OHG. until after the HG. sound-shifting has been treated. See $\S 221$.

\section{Other Consonant Changes.}

$\S 200$. Most of the sound-changes comprised under this paragraph might have been disposed of in the paragraphs dealing with the shifting of the Indg. mediae and mediae aspiratae, but to prevent any possible misunderstanding or confusion it was thought advisable to reserve them for a special paragraph.

The Indg. mediae and mediae aspiratae became tenues 
102

before a suffixal $\mathbf{t}$ or $\mathbf{s}$ already in the pre-Germanic period :-

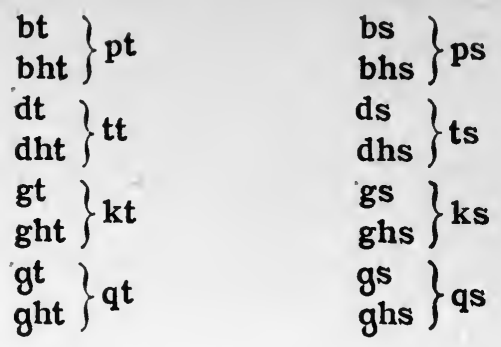

Examples are: Lat. nūptum, nūpsī, beside nūbere, to marry; Skr. loc. pl. patsú, beside loc. sing. padí, on foot; Lat. rēxī, rectum, beside regere, to rule; Lat. vēxī, vectum, beside vehere, to carry, root wegh ; Lat. lectus, Gr. $\lambda \epsilon_{\chi} \times s$, bed, Goth. ligan, to lie down; Skr. yuktá., Gr.

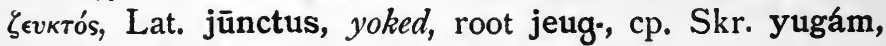

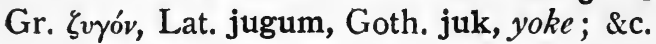

Then pt, kt, qt ; ps, ks, qs were shifted to ft, $x \mathrm{t}$; fs, $x^{s}$ at the same time as the original Indg. tenues became voiceless spirants (\$192). And tt, ts became ss through the intermediate stage of $\mathrm{pt}, \mathrm{ps}$ respectively. ss then became simplified to $\mathbf{s}$ after long syllables and before $\mathbf{r}$, and then between the $\mathbf{s}$ and $\mathbf{r}$ there was developed $\mathbf{a}$.

This explains the frequent interchange between $\mathbf{p}, \mathbf{b}(\mathbf{b})$, and $\mathbf{f}$; between $\mathbf{k}, \mathbf{z}(\mathbf{g})$, and $\mathbf{h}$ (i.e. $\mathbf{x}$ ); and between $\mathbf{t}, \mathbf{p}$, $\mathrm{d}(\mathrm{d})$, and ss, $\mathbf{s}$ in forms which are etymologically related.

p, b (b)-f. Goth. skapjan, OE. scieppan, OHG. skephen, to create, beside Goth. ga-skafts, creation, OE. gesceaft, OHG. giscaft, creature; Goth. giban, OHG. gëban, to give, beside OE. OHG. gift, gift; OHG. wëban, to weave, beside English weft.

k, 3 (g)-h. Goth. waúrkjan, OE. wyrcan, OHG. wur. ken, to work, beside pret. and pp. Goth. waúrhta, waúrhts, OE. worhte, worht, OHG. worhta, giworht; OE. OHG. 
magan, to be able, beside pret. sing. Goth. mahta, OE. meahte, OHG. mahta; OE. OHG. bringan, to bring, beside pret. and pp. OE. brōhte, brōht, OHG. brāhta, brāht.

t, p, đ(d)-ss, s. Goth. OE. witan, to know, beside pret. Goth. wissa, OE. wisse, OHG. wissa (wëssa); Goth. qipan, to say, beside ga-qiss, consent; Goth. ana-biudan, to command, beside ana-busns, commandment, pre-Germanic *bhŭtsni-, root bheudh-.

ss became $\mathbf{s}$ after long syllables and before $\mathbf{r}$ : Goth. háitan, OE. hātan, to call, beside OE. hǣs from *haissi., command; Goth. OE. witan, to know, beside Goth. un. weis, unknowing, OE. OHG. wis, wise; Goth. itan, OE. etan, to eat, beside OE. ̄̄s, OHG. ās, carrion; OHG. pret. muosa, beside pres. muoz, I must. Goth. gup.blōstreis, worshipper of God, OHG. bluoster, sacrifice, cp. Goth. blōtan, to worship; OE. fōstor, sustenance, cp. Goth. fōd. jan, to.feed.

Instead of ss (s) we often meet with st. In such cases the st is due to the analogy of forms where $t$ was quite regular, e.g. regular forms were Goth. last, thou didst gather, inf. lisan; Goth. sloht, thou didst strike, inf. slahan; OE. meaht, OHG. maht, thou canst, inf. magan ; then after the analogy of such forms were made 2. pers. sing. Goth. wáist for *wáis, OE. wāst for *wās, OHG. weist for *weis, thou knowest; regular forms were pret. sing. Goth. waúrhta, OE. worhte, OHG. worhta, Goth. inf. waúrk. jan, to work; then after the analogy of such forms were made OE. wiste, beside wisse, OHG. wësta, beside wissa (wëssa), I knew.

For purely practical purposes the above laws may be thus formulated :-every labial $+t$ became $\mathrm{ft}$; every guttural $+t$ became $h t$; and every dental $+t$ became ss, $s$ (st).

$\$ 201$. Prim. Germanic $\mathbf{z} \mathbf{w}$, which arose from Indg. $g h$, and from Indg. $\mathbf{q}$ by Verner's law, became 3 before $\mathfrak{u}$, in 
other cases it became w, as Goth. magus, boy, beside mawi from *ma(z)wî́, girl; OE. pret. pl: sǣgon, they saw, beside pp. sewen; Goth. siuns, OE. sēon (sion), from *se(z)wnís, a seeing, face; Goth. snaiws, OE. snāw (with -w from the oblique cases), from *snai(z)was, prim. form *snoighós, snow.

§ 202. Assimilation :- •nw. > •nn., as Goth. OHG. rin. nan, to run, from *rinwan; Goth. kinnus, OHG. kinni from *genw., Gr. $\gamma^{\prime} \in v-s$, chin, cheek; Goth. minniza, OHG. minniro from *minwizō, less, cp. Lat. minuō, Gr. $\mu \iota v \dot{\theta} \theta \omega$, I lessen; OHG. dunni, thin, cp. Skr. fem. tanvî́, thin.

-md. > .nd., as Goth. OE. hund, OHG. hunt, prim. form *kmtóm, hundred; Goth. skaman, OHG. scamēn, to be ashamed, beside Goth. skanda, OHG. scanta, shame.

.1n- > -11., as Goth. fulls, OHG. (gen. folles), Lithuanian pilnas, full; Goth. wulla, OE. wull, OHG. wolla, Lithuanian wilna, wool.

Prim. Germanic bn, đn, $\mathbf{3}^{\mathrm{n}}=$ Indg. $\mathrm{pn}^{\prime}, \mathrm{tn}^{\prime}, \mathrm{kn}^{\prime}, \mathrm{qn}^{\prime}$ (by Verner's law), and bhn', dhn', ghn', ghn', became $\mathrm{bb}$, đđ, 33 before the principal accent, then later $\mathrm{bb}, \mathrm{dd}$, gg; and in like manner Indg. bn', dn', gn', gn'- became $\mathbf{b b}, \mathrm{dd}, \mathrm{gg}$. And these mediae were shifted to $\mathbf{p p}, \mathbf{t t}, \mathbf{k k}$ at the same time as the original Indg. mediae became tenues ( $(193)$. These geminated consonants were simplified to $\mathbf{p}, \mathbf{t}, \mathbf{k}$ after long syllables. Examples are $\mathrm{OE}$. hnæp (gen. hnæppes), OHG. napf, from *xnabn' or xnabn', basin, bowl; OE. hoppian, MHG. hopfen, from

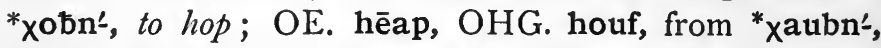
heap; OE. cnotta, from *knođn', beside OHG. chnodo, chnoto, knot; Goth. hueits, OE. hwit, OHG. (h)wiz, from ${ }^{*} \mathrm{x}$ wiđn', white; OE. smocc, OHG. smoccho, from *smozn', smock; OE. bucca, OHG. boc (gen. bockes), from Indg. *bhugnó,, buck.

\$203. Indg. $z+$ media became $\mathbf{s}+$ tenuis, as Goth. asts, $\mathrm{OHG}$. ast $=\mathrm{Gr}$. ö $\zeta o s$, from *ozdos, branch, twig; OE. 
OHG. nest, Lat. nidus, from *ni-zdos, nest, related to root sed., sit.

Indg. $z+$ media aspirata became $z+$ voiced spirant, as Goth. mizdō, OE. meord, pay, reward, cp. O. Bulgarian mǐzda, Gr. $\mu \sigma \theta$ ós, pay; OE. mearg, OHG. marg, O. Bulgarian mozgŭ, marrow, root mezgh.; Goth. huzd, OE. hord, OHG. hort, hoard, treasure, root kuzdh.

$\S$ 204. Guttural $\mathbf{n}(y)$ disappeared before $x$, as Goth. OHG. fāhan, from *fayxanan, to seize, catch; OHG. pret. dāhta, beside inf. denken, to think. See §54.

$\$$ 205. $x$ became an aspirate (written $h$ ) initially before vowels, and probably also medially between vowels, as Goth. OE. hund, OHG. hunt, hundred; Goth. taíhun, OHG. zëhan, ten.

Intervocalic $x^{\mathbf{w}}$ became $x$ in Old Norse and the West Germanic languages, as OHG. sëhan, OE. sēon, O. Icel. sjā, from *sehan, beside Goth. saíluan, to see; OHG. aha, beside Goth. ahua, Lat. aqua, water.

\$206. The consonants, which arose from the Indg. final explosives $(t, d)$, were dropped in prim. Germanic, as Goth. baírái, OHG. bëre, from an original form *bhéroĩt, he may bear. See $\$ 161$.

$\$ 207$. Original final $-\mathrm{m}$ became $\mathrm{n}$ in prim. Germanic. This $\cdot \mathbf{n}$, as also Indg. $\cdot \mathbf{n}$, disappeared in dissyllabic and polysyllabic words. For examples, see $\$ 161$.

$\$ 208$. w disappeared before $\mathfrak{u}$, as Goth. kaúrus, from *kwuruz, heavy ; OE. sund, a swimming, from *swumda., beside inf. OE. OHG. swimman; OHG. pp. gidungan, beside inf. dwingan, to force. In verbal forms the $\mathbf{w}$ was mostly reintroduced in the pret. pl. and pp. after the analogy of forms which regularly had w, e.g. OHG. swummum, giswumman, swungum, giswungan, swullum, giswollan, beside inf. swimman, to swim, swingan, to swing, swëllan, to swell. For levelling out in the opposite direction; cp. OE. OHG. singan, beside Goth. 
siggwan (regular form), to sing; OE. sincan, OHG. sinkan, beside Goth. sigqan, to sink.

\$209. Initial and medial sr became str, as OE. strēam, OHG. strōm, stream, cp. Skr. srávati, it flows; OHG. dinstar, from * pinstra-, dark, cp. Skr. támisram, darkness ; pl. OE. ēastron, OHG. ōstarūn, Easter, cp. Skr. usră, dawn; Goth. swistar, OE. sweostor, OHG. swëster, sister, with $\mathbf{t}$ from the weak stem form, as in the locative sing. Goth. swistr=prim. Germanic *swesri=Skr. dat. svásrē.

\$210. The remaining Indg. consonants suffered no further material changes which need be mentioned here. Summing up the results of $\$ \$ 102-209$, we arrive at the following system of consonants for the close of the prim. Germanic period :-

$$
\text { Labial. Inter- Dental. } \begin{gathered}
\text { Palatal and } \\
\text { Guttural. }
\end{gathered}
$$

Explosives $\begin{cases}\text { Voiceless } & \mathbf{p} \\ \text { Voiced } & \mathbf{b}\end{cases}$

Spirants $\begin{cases}\text { Voiceless } & \mathbf{f} \\ \text { Voiced } & \mathbf{b}\end{cases}$

Nasals

Liquids

Semivozvels

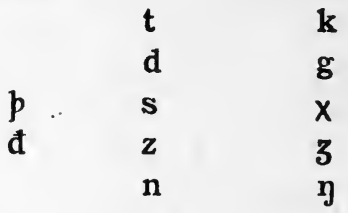

$1, r$

$\mathbf{W}$

$\mathbf{j}$ (palatal)

To these must be added the aspirate $h$.

\section{CHAPTER XI}

SPECIAL WEST GERMANIC MODIFICATIONS OF THE GENERAL GERMANIC CONSO. NANT-SYSTEM. THE HIGH GERMAN SOUND-SHIFTING, ETC.

§211. Prim. Germanic z, which arose from s (\$ 199), became $\mathbf{r}$ medially, and was dropped finally, as $\mathrm{OE}$. māra, OHG. mēro = Goth. máiza, greater; pp. OE. coren, 
OHG. gikoran, beside inf. OE. cēosan, OHG. kiosan, to choose; OE. dæg, OHG. tag = Goth. dags, from *dazaz, day; OE. OHG. sunu = Goth. sunus, from *sunuz, son; OHG. gast = Goth. gasts, from *3astiz, guest, stranger.

$\S 212$. Prim. Germanic đ ( $\$ 195-6)$ became d, as OE. ceald, OHG. kalt, cold; OE. healdan, OHG. haltan, to hold; OE. lǣdan, OHG. leiten, to lead; OE. rēad, OHG. rōt, red.

§ 213. In West Germanic all single consonants, except $\mathbf{r}$, were doubled after a short vowel before a following $\mathbf{j}$. This $\mathbf{j}$ was mostly retained in Old Saxon, but was generally dropped in OE. and OHG., as OS. sellian, OE. sellan, OHG. sellen, Goth. saljan, to give up; OE. fremman, OHG. fremmen, Goth. *framjan, to perform; OHG. gen. kunnes, Goth. kunjis, of a race; OHG. frauwa, frouwa, from *frawjō., woman (§ 232); OE. lecg(e)an, Goth. lagjan, to lay; OE. settan, Goth. satjan, to set; OE. scieppan, Goth. skapjan, to create. But $\mathrm{OE}$. nerian, OHG. nerien = Goth. nasjan, to save.

$\mathrm{bj}$, đj, and $\mathrm{z}^{\mathrm{j}}$ became $\mathrm{bb}$, dd, and $\mathrm{gg}$, as $\mathrm{OE}$. $\operatorname{sib}(\mathbf{b})$ (gen. sibbe), Goth. sibja (b), relationship; OE. biddan, Goth. bidjan (đ), to beg, pray; OE. hycg(e)an, Goth. hugjan, to think.

For the OHG. treatment of West Germanic bb, dd, gg, and pp, tt, kk, see $\$$ 217-18.

Note. - The $\mathbf{j}$ in the combination $\mathbf{j i}$ was dropped before the West Germanic doubling of consonants took place, as e. g. in the 2. and 3. pers. sing. of the pres. indic., as OHG. hevis, hevit $=$ Goth. hafjis, hafjip, beside inf. heffen $=$ Goth. hafjan, to raise; OHG. fremis, fremit, beside inf. fremmen, to perform.

$\S$ 214. $\mathbf{p}, \mathbf{t}$, and $\mathbf{k}$ were also doubled in West Germanic beiore a following $r$ or 1 . The doubling regularly took place in the inflected forms (as OHG. gen. ackres, bittres, hlüttres, pl. epfli), and was then transferred to the uninflected forms by levelling, as OHG. kupfar, from Lat. 
cuprum, copper; OE. snottor, OHG. snottar, Goth. snutrs, wise; OHG. hlūttar, Goth. hlūtrs, pure, clear; OHG. bittar, OE. bittor, bitter; OHG. ackar, Goth. akrs, field, acre; OE. æppel, OHG. aphul, O. Icel. epli, apple; OS. luttil, OHG. lutzil, little. See §165.

$\S 215$. Doubling of consonants also regularly took place before a following $\mathbf{n}$ in the weak declension of nouns, as sing. nom. ${ }^{*}$ knabō, boy, acc. ${ }^{*}$ knabonun, beside pl. gell. ${ }^{*}$ knabbnō(n), dat. *knabbnum. This interchange between the single and double consonants gave rise to levelling in a twofold direction, so that one or other of the forms was transferred to all cases. This explains, e. g., NHG. knabe, rabe, beside knappe, squire, rappe, black horse: OHG. knabo, rabo, beside knappo, rappo; OHG. roggo, rye ; OHG. troffo, drop, trahho (from Lat. draco), dragon, beside tropfo, traccho.

\section{The High German Sound-Shifting.}

$\S$ 216. The most striking feature in which High German differs from the other West Germanic languages is the general shifting which certain consonants underwent. This process had its beginning before the period of the oldest HG. monuments, and was practically completed by the end of the eighth century.l The prim. HG. language had the following explosives and spirants:-

$$
\text { Labial. Inter- Dental. Guttural. }
$$

\begin{tabular}{|c|c|c|c|c|c|}
\hline & Voiceless & $\mathbf{p}$ & 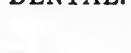 & $\mathbf{t}$ & $\mathbf{k}$ \\
\hline & Voiced & b & - & d & $\mathrm{g}$ \\
\hline Spirants & $\left\{\begin{array}{l}\text { Voiceless } \\
\text { Voiced }\end{array}\right.$ & $\begin{array}{l}f \\
\text { b }\end{array}$ & p & $\mathbf{s}$ & $x(h)$ \\
\hline
\end{tabular}

Note. - b occurred initially, medially after $\mathrm{m}$, and in the combination bb (\$ 213). d occurred in all positions. $\mathrm{g}$ occurred medially after $\mathfrak{y}$, as also in the combination gg.

$\S 217$. The only consonants, which were shifted through- 
out the whole of the HG. dialects, were the voiceless explosives $\mathbf{p}, \mathbf{t}, \mathbf{k}$. The shifting of the voiced spirants and explosives did not extend over all the HG. dialects. The shifting of $\mathrm{p}$ to $d$ through the intermediate stage of $\mathrm{d}$ took place in historic times; beginning first in Upper German about $75^{\circ}$ A. D., it had gradually extended over all the HG. dialects by the end of the eleventh century.

$\mathbf{p}, \mathbf{t}, \mathbf{k}$ remained unshifted in the combinations $\mathbf{s p}, \mathbf{s t}$, sk as also in the combinations tr, ht, ft. See $\$ 192$, note.

The voiceless explosives $\mathbf{p}, \mathbf{t}, \mathbf{k}$ underwent a twofold treatment according to their position in the word: (I) medially or finally after vowels; (2) initially, medially and finally after consonants $(1, \mathrm{~m}, \mathrm{n}, \mathbf{r})$ and when doubled.

r. Prim. HG. single $p, t, k$ were shifted in OHG. to the voiceless double spirants $\mathrm{ff}, \mathbf{z z}, \mathrm{hh}$ (also written $\mathbf{c h}, \mathbf{h}$ ).

$\mathrm{p}>\mathrm{ff}$. OE. open, OHG. offan, open; OE. scip, OHG. skif, ship; OE. slǣpan, OHG. slāffan, to sleep; OE. ūp, OHG. ūf, $u p$; OE. wǣpen, OHG. wāffan, weapon.

t> 33. OE. etan, OHG. ëzzan, to eat; OE. hātan, OHG. heizzan, to call ; OE. hwæt, OHG. hwaz, what? ; OE. wæter, OHG. wazzar, water.

$\mathrm{k}>\mathrm{hh}$. OE. ic, OHG. ih, $I$; OE. macian, OHG. mahhōn, to make; OE. sprecan (specan), OHG. sprëh. han, to speak; OE. tãcen, OHG. zeihhan, token, sign; $\mathrm{OE}$. wacian, OHG. wahhōn, to be awake.

The double consonants were simplified according to $\S 223$.

2. $\mathbf{p}, \mathbf{t}, \mathbf{k}$, initially, medially and finally after consonants $(1, m, n, r)$, and when doubled, were shifted to the affricatae pf (also written ph), $\mathbf{t z}$ (generally written $\mathbf{z z}$ and $\mathbf{z}$ ), and $\mathbf{k h}(=\mathbf{k}+\mathbf{x}$, also written $\mathbf{c h})$. Here a distinction must be made between the various dialects. $t$ became $z$ in all HG. dialects. p became pf in Upper German and East Franconian, but remained unshifted in Rhenish Franconian except after 1 and $\mathbf{r}$; it also remained unshifted in 
Middle Franconian. $\mathbf{k}$ became $\mathbf{k h}$ (written $\mathbf{c h}, \mathbf{c h}=$ $\mathbf{k}+\mathbf{x}$ ) in High Alemanic (Swiss), but remained unshifted in the other dialects.

p>pf. OE. pæp, UG. and EFr. pfad, RFr. and MFr. pad, path; OE. pund, UG. and EFr. pfunt, RFr. and MFr. punt, pound; OE. weorpan, UG. EFr. and RFr. wërpfan, MFr. wërpan, to throw; UG. EFr. and RFr. hëlpfan, MFr. hëlpan, to help; OE. gelimpan, UG. and EFr. gilimpfan, RFr. and MFr. gilimpan, to be meet; OE. scieppan, UG. and EFr. skepfen, RFr. and MFr. skeppen, to create.

t >z. OE. tægl, tunge, OHG. zagal, tail, zunga, tongue; OE. sittan, settan, OHG. sitzen, to sit, setzen, to set; OE. sealt $=$ OHG. salz, salt; $\mathrm{OE}$. sceatt $=\mathrm{OHG}$. scaz, money.

k $>$ kh. OE. cnēo, cealf $=$ OHG. knio, kalb, but High Al. chneo, knee, chalp, calf; OE. weccan, OHG. wecken, but H.Al. wechan, to awake; OE. drincan, OHG. trinkan, but H.Al. trinchan, to drink; OHG. kind, child, folk, folk, wërk, work, but H.Al. chind, folch, wërch.

Note.-Instead of $p f$ we mostly find $f$ initially and frequently $f$ (ff) medially in H.Al. This is probably merely an inexact attempt to represent the affricata pf. This is supported by the fact that the modern $\mathrm{H}$.Al. dialects have pf initially.

$\S 218$. The voiced explosives and voiced spirants did not undergo the same universal shifting as the voiceless explosives. The following are the chief points to be noticed here concerning these consonants :-

I. Upper and Middle Franconian retained b initially and medially, as also bb. In Upper German bb became pp, and $\mathbf{b}$ appears as $\mathbf{p}$ beside $\mathbf{b}$. $\mathbf{p}$ and $\mathrm{b}$ fluctuated initially in Upper German throughout the Middle Ages : bëran, to bear, bintan, to bind, lamb, lamb, sibba, peace, beside Upper German përan, pintan, lamp, sippa. See § 210. 
b remained medially and became $f$ finally in Middle Franconian and in some Middle German dialects, as gëven, to give, pret. gaf; gen. wives, beside nom. wif, woman. It was shifted to $b$ in Upper Franconian, whereas it appears as $\mathbf{p}$ (rarely $\mathbf{b}$ ) in the oldest Upper German monuments. b came to be used generally in Alemanic in the ninth and in Bavarian in the eleventh century: UFr. lëbēn, to live, sibun, seven, ubil, evil, gëban, to give, pret. gab = UG. lëpēn, sipun, upil, gëpan, gap. See § 219.

2. All $\mathrm{HG}$. dialects shifted dd to $\mathrm{tt}$, as $\mathrm{OE}$. biddan, OHG. bitten, to request; OE. midd, OHG. mitti, middle.

$\mathrm{d}$ remained initially and medially in Middle and Rhenish Franconian (but South RFr. $t$ medially). It became $\mathbf{t}$ in all positions in Upper German and East Franconian, and finally also in Middle and Rhenish Franconian, thus $\mathrm{OE}$. dohtor, daughter, bindan, to bind, bēodan, to offer, appear in MFr. and RFr. as dohter, bindan, biodan, and in UG. and EFr. as tohter, bintan, biotan; OE. dēad, dead, word, word $=$ tōt, wort in all dialects.

3. $\mathrm{ng}(\$ 195)$ remained in OHG. ; it is rarely written $\mathrm{nk}$ in Upper German, as OE. OHG. singan, to sing ; swingan, to swing.

gg remained in Franconian, but was shifted to $\mathbf{k k}$ in Upper German, as OS. liggian, Franconian liggen, to lie down, OS. hruggi, Franconian ruggi, back, beside UG. likken, rucki.

Initial $\mathbf{z}$ became $\mathbf{g}$ in Franconian (except North Middle Franconian where it remained). It became $\mathbf{k}$ (also written c before guttural vowels) in Upper German, as OE. giest, Franconian gast, Upper German kast, guest; OE. giefan, Fr. gëban, UG. këban, këpan, to give.

Medial $\mathbf{z}$ remained in Franconian (written $\mathbf{g}$ ), but became a voiceless lenis (written $\mathbf{g}$, rarely $\mathbf{k}, \mathbf{c}$ ) in Upper German. The writing of $\mathbf{k}, \mathbf{c}$ medially disappeared in UG. during the tenth century. From then onwards $g$ only was used. 
Thus OE. stigan, to rise, eage, eye, appear in Fr. and UG. as stigan, ouga, more rarely in UG. as stican, ouca.

Final $\boldsymbol{z}$ became a voiceless lenis (generally written $\mathbf{c}$, but also often $\mathrm{g}$ ) in High and Low Alemanic. It became $\mathrm{x}$ (generally written $\mathbf{g}$ ) in Bavarian, Swabian, Alsatian, and Franconian, thus OE. dæg, day, mæg, I may, appear in High and Low Alemanic as tac, mac, and in Fr., \&c., as tag, mag.

\$ 219. The description, given above of the changes which the primitive $H G$. voiced explosives and voiced spirants underwent in OHG., is more or less based upon letter-change rather than upon sound-change. The real diffculty lies with the development of primitive HG. $\mathbf{b}$ and $\mathbf{z}$ in OHG. From OHG. alone it is impossible to decide to what extent they remained spirants or became explosives, especially in the Franconian dialects. From the Modern Franconian dialects it is clear that $\mathrm{b}$ remained medially and became $f$ finally over an extensive area. In like manner, the modern dialects show that medial 3 must have remained in Franconian, and that final 3 became $x$ (written g) in Bavarian, Swabian, Alsatian, and Franconian.

In Upper German, where p, pp and $\mathbf{k}$, ck interchange with $\mathrm{b}, \mathrm{bb}$ and $\mathrm{g}, \mathrm{gg}$, it is certain that the original spirants had become explosives. In this case, it is not a question of voiced explosives having been shifted to voiceless explosives. The fluctuation in the orthography was merely due to the uncertainty existing in the writer's mind as to how he should represent the lenes $b, g$. What are written b, $\mathrm{d}, \mathrm{g}$ in OHG. were not voiced explosives at all, but voiceless lenes. These only differed from the voiceless explosives (fortes) in the intensity or force of articulation. Both sets of consonants were voiceless, just as they are now in most modern $\mathrm{HG}$. dialects. In some modern $\mathrm{HG}$. dialects the lenes and fortes have fallen together in fortes, but most dialects still preserve the distinction. 
\$220] The High German Sound-shifting I I 3

The voiced sounds $\mathbf{b}, \mathbf{d}, \mathbf{g}$ of the NHG. standard language are of North German origin, where Low German was originally spoken.

The rules for the pronunciation of the above sounds as prescribed for the language of the stage are: $b, d$ are voiced explosives initially, and medially between voiced sounds, but voiceless explosives before voiceless consonants, and finally. $\mathbf{g}$ is a voiced explosive initially. It is also recommended medially between vowels, but most North Germans pronounce it as 3 (taze) in this position. Finally it is $\mathbf{k}$ (tak) except in the suffix .ig where $\mathrm{x}$ is prescribed (but ew'ze = ewige). Most North Germans, however, pronounce the sound as $\mathrm{x}$ when final (tax). The rules as laid down for the pronunciation of the language of the stage are now generally recognized as the standard among the educated people of Middle and South Germany.

§220. The table below gives a summary of the HG. sound-shifting, so far as the changes are indicated in OHG. orthography. The shifted sounds are printed in italics.

Prim. Germ.

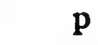

Goth.

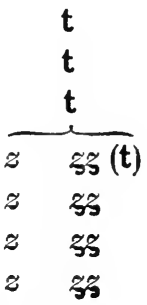

$\mathbf{k}$

OE.

M. Franc.

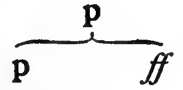

R. Franc.

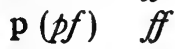

E. Franc.

$p f$

U. German

$f f$

Prim. Germ. D

Goth. b, b (f)

$\mathrm{OE}$.

M. Franc.

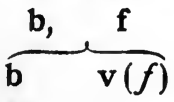

R. Franc.

b $b$

E. Franc.

b $b$

U. German

$p$ (b) $b(p)$

d

d, $\mathrm{d}(\mathrm{p})$

d, $\mathrm{d}$

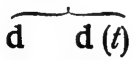

d $\mathrm{d}(t)$

$t \quad t$

$t \quad t$ k

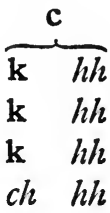

3

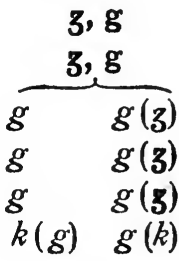


Note. - I. In Middle Franconian $t$ only remained unshifted in the pronominal neuter forms dat, wat, dit, it, allet $=$ MHG. daz, waz, diz, ëz, allez; in the pret. and pp. of weak verbs which have $\mathbf{t z}(\mathbf{z}), \mathbf{z}$ in the present, as pret. satte, latte, groete, pp. gesat, gelat, gegroet, beside inf. setzen, to set, letzen, to hinder, griiezen, to greet; and in a few other words.

2. The East Franconian consonants are usually taken as the normal in this book, because they mostly agree with those of Middle and New High German.

$\S 221$. Few $\mathrm{OHG}$. forms were given in the paragraph relating to Verner's law ( $\$ 199)$ in order that they might be left until after the discussion of the HG. sound-shifting. From what has been said in $\$ \S 217-8$, it will be seen that the interchanging pairs of consonants in OHG. are :-

$$
\begin{aligned}
& \text { f-b (UG. also p); d (older th, dh) - } t \text {; } \\
& \text { h (= prim. Germ. } x \text { )-g (UG. also k, c) ; } \\
& \mathbf{h}(=\text { prim. Germ. } \mathbf{x w})-\mathbf{w} \text { (prim. Germ. } \mathbf{z} \mathbf{w}) \text {; } \\
& \text { h (= prim. Germ. } \mathbf{y X})-\mathbf{n g} ; \mathbf{s}-\mathbf{r} \text {. }
\end{aligned}
$$

f-b. heffen, Goth. hafjan, to raise, pret. pl. huobun, pp. gihaban; urhab, reason; wolf : wulpa, she-wolf.

d-t. findan, to find, snidan, to cut, wërdan, to become, pret. pl. funtun, snitun, wurtun, pp. funtan, gisnitan, wortan ; tōd, death : tōt, dead.

h-g. slahan, to strike, ziohan, to draw, pret. pl. sluogun, zugun, pp. gislagan, gizogan; heri.zogo, leader of an army; swëhur, father-in-law: swigar, mother-inlaw ; zëhan, ten: zwein.zug, twenty.

$\mathbf{h}$-w. lihan, to lend, sihan, to strain, pret. pl. liwun, siwun, pp. giliwan, gisiwan; aha, water: ouwa (from *a(g)wjố-), marshy land.

$\mathbf{h}$-ng. fāhan, to seize, hāhan, to hang, pret. pl. fiangun, hiangun, pp. gifangan, gihangan.

s-r. friosan, to freeze, kiosan, to choose, pret. pl. frurun, kurun, pp. gifroran, gikoran ; haso, hare, beside OE. hara. 
Nore.-I. In OHG., and still more in MHG. and NHG., this law.was frequently disturbed through the effect of analogy and levelling. See $\$ \S 490-512$.

2. Causative verbs had originally suffix accentuation, and therefore also exhibit the change of consonants given above, as gi-nësan, to be saved: nerien, to save; hāhan, to hang : hengen, to hang ; wërdan, to become: ir-werten, to injure; lidan, to go : leiten, to lead; \&c.

\section{CHAPTER XII}

\section{THE HIGH GERMAN CONSONANTS}

$\S$ 222. Before entering upon the history of the individual consonants, it will be well to treat here several points concerning the HG. consonants in general.

$\S 223$. In $\mathrm{OHG}$. and $\mathrm{MHG}$. the double consonants 11 , $\mathrm{mm}, \mathrm{nn}, \mathrm{gg}, \mathrm{kk}, \mathrm{tt}, \mathrm{ss}, \& \mathrm{c}$., were really long, and were pronounced long as in Italian and Swedish, thus OHG. bit.ten, to beg; rin.nan, to run; wis-sa, I knew. Whereas double consonants in NHG. are short and merely indicate that the preceding vowel is short, as wolle, schwimmen, schwamm, nennen, brïcke, bitten, wissen, \&c.

$\mathrm{OHG}$. and $\mathrm{MHG}$. consonants were simplified in the following cases:-

r. When they became final, as fël, hide, gen. fëlles ; far, bull, pl. farri ; uninflected form grim, fierce, inflected form grimmēr; swimman, to swim, pret. sing. swam; rinnan, to run, pret. sing. ran ; man, man, gen. mannes ; ëzzan, to eat, pret. sing. āz; kus, kiss, gen. kusses ; sprëhhan, sprëchan, to speak, pret. sing. sprah ; \&c.

2. Before other consonants, as kunnan, to know, kussen, to kiss, brennen, to burn, pret. sing. konda, kusta, branta; \&c.

3. Medially after long vowels and consonants, as lāzan, 
to let, leave, lūtar, pure, slāfan, to sleep, beside older lāzzàn, lūttar, slāffan ; āhten, to persecute, pret. sing. āhta (from *āhtta); leiten, to lead, pret. sing. leita (older leitta), MHG. leite; wenten, to turn, pret. sing. wanta (from *wantta).

$\S 224$. We have already seen $(\S 105)$ that short vowels in open syllables began to be lengthened in Middle German at the beginning and in Upper German at the end of the thirteenth century, and that short vowels remained when followed by consonant combinations including double consonants, thus the vowels in MHG. alle, bitten, knappe, swimmen, trëffen, have remained short

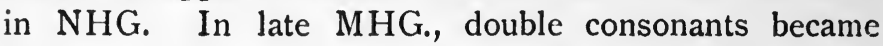
shortened, although they were generally retained in writing. Then, after the analogy of the double consonants already existing, they became used in other words to indicate that a preceding vowel was short; at first medially only and then at a later period also finally. This principle has been generalized in NHG. except in the case of $\mathbf{s}(=\mathrm{MHG} .3)$ where no related forms with medial ss (= MHG. 33) exist beside them. Thus MHG. bleter, buter, doner, gegrifen, gekomen, genomen, gepfifen, gesoten, himel, komen, spoten, sumer, veter $=$ NHG. blätter, butter, donner, gegriffen, gekommen, genommen, gepfiffen, gesotten, himmel, kommen, spotten, sommer, vetter. MHG. blat, brët, got, haz, muoz, quëc, pret. san, span, swam ; schif, vaz, vël, vol, vrum, weiz = NHG. blatt, brett, gott, hass, muss, queck-, pret. sann, spann, schwamm; schiff, fass, fell, voll, fromm, weiss; but MHG. allez, daろ, ëz, üz, waz, \&c. = NHG. alles, das, es, aus, was, \&c.

NorE.-It is sometimes stated that in passing from MHG. to NHG. all stem syllables became long either by lengthening the vowel or by doubling the consonant. This statement is inaccurate. The double consonants in NHG. are short and are merely used to indicate that the preceding vowel is short.

$\$ 225$. Notker's law of initial consonants, generally 
called Notker's Anlautsgesetz in German, is of great importance for determining the pronunciation of what was written $b, d, g$ in his dialect (Alemanic) at the end of the tenth century. Briefly stated, the law is : the voiceless lenes $b, d, g$ were only used when the precedirg word ended in a vowel or in one of the voiced sounds $1, m, n, r$, in all other cases $\mathbf{p}, \mathbf{t}, \mathbf{k}$ were used. That is, there existed in Notker's dialect the interchange between the voiceless lenes $\mathbf{b}, \mathbf{d}, \mathbf{g}$ and the fortes $\mathbf{p}, \mathbf{t}, \mathbf{k}$. He always wrote $\mathbf{t}$ for Germanic d ( $\$ 218$ ), as tes tages-temo tage (never dage). His interchanged $d$ and $t$ go back to Germanic $p$. $H$ is rule for the use of initial $v$ and $f$ was : $f$ after voiceless sounds, $\mathbf{v}$ and often $\mathbf{f}$ in other cases. The law must have existed generally in Upper German of the MHG. period, but initial $b, d, g, v$ were generalized in MHG. orthography, except that $\mathbf{p}$ was common in Bavarian. Examples are: ter bruoder-unde des pruoder; tes koldes-unde demo golde ; in dih-unde daz tih ; taz urlub kab ; mag pezera sin. The two last examples prove that $\mathbf{b}$ and $\mathbf{g}$ were voiceless.

\$226. In MHG. the lenes $b, d, g$ became the fortes $\mathbf{p}, \mathbf{t}, \mathbf{c}(\mathbf{k})$ when they ended a syllable, that is when they came to stand finally; or medially before voiceless consonants. Traces of the law existed already in late OHG. The interchange between the lenes and fortes includes two independent processes, viz. the change of the medial lenes $b, d, g$ to the final fortes $p, t, k$, and the change of the final fortes $\mathbf{f}, \mathbf{s}$ to the medial intervocalic lenes $v$, and to what is written $\mathbf{s}$ (cp. also NHG. lesen, las). It must be noted that in MHG. the interchanging pairs of consonants were all voiceless and that the difference merely consisted in the intensity or force with which the sounds were produced. This is quite different from NHG. where the interchange is between voiced and voiceless sounds except in the case of $f$ which is voiceless in all positions in 
native words. Examples are: gëben, to give, gelouben, to believe, pret. gap, geloupte ; gen. lambes, lïbes, beside nom. lamp, lamb, lip, life; binden, to bind, wërden, to become, pret. bant, wart ; gen. kindes, tōdes, beside nom. kint, child, tōt, death; gen. bërges, tages, beside nom. bërc, mountain, tac, day; biegen, to bend, zeigen, to show, pret. bouc, zeicte ; langer, beside lanc, long; manege, many, beside manec; gen. brieves, hoves, beside nom. brief, letter, hof, yard; kiesen, to choose, lësen, to read, lœsen, to loose, pret. kōs, las, lōste ; hiuser, houses, beside hūs.

Intervocalic $h$ was no longer a spirant in OHG. ( $\$ 205)$, but it remained a spirant when final and was written $\mathbf{c h}$ in

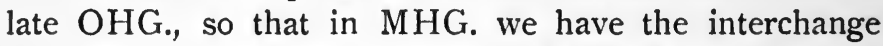
between medial intervocalic $\mathrm{h}$ and final $\mathrm{ch}$, as lihen, to lend, sëhen, to see, pret. lēch, sach; gen. hōhes, beside nom. hōch, high ; nāhe, nearness, beside nāch, near.

NoTE. - The above rule is not so rigid in the orthography of MHG. manuscripts, as it is generally made to appear in MHG. grammars and in the printed editions of MHG. authors. From our knowledge of the later history of the language, it is certain that the rule existed in pronunciation. In the orthography, however, the medial intervocalic forms of the consonants occur very frequently finally by levelling out the medial forms, just as has almost uniformly been done in NHG. orthography. The levelling out of the medial forms was especially common in Middle German, as kind, lamb, lieb, tag, \&c.

\$227. In NHG. the voiced explosives b, d, $\mathbf{g}$ have become voiceless when final or when followed by a voiceless consonant, but $\mathbf{b}, \mathrm{d}, \mathrm{g}$ are retained in writing, as $\mathrm{gab}$, glaubte, lobte; band, kind, ward; berg, bog, tag, sagst, sagte. Final $\mathbf{s}$ has remained voiceless, but has become voiced between vowels, as lesen, lösen, beside las, löste.

$\$ 228$. In $N H G$. the voiceless explosives $p, t, k$ have become aspirated initially and medially before accented 
§\$22-31] The High German Consonants II9

vowels, and also finally after accented vowels. In the last position are, of course, included what are written $\mathbf{b}, \mathbf{d}$, and also $\mathbf{g}$ in those parts of Germany where final $\mathbf{g}$ is pronounced as $\mathbf{k}(\$ 219)$. Examples are : paar, teil, kein, natur, knapp, matt, not, dick, ab, feld, hand, tag.

\section{The Semi-vowels.}

$\mathbf{w}$

§ 229. Germanic $\mathbf{w}=$ Engl. $\mathbf{w}$ in wet (generally written uu, uv, vu, vv in OHG. manuscripts) remained initially before vowels in OHG. and MHG., as OHG. wahsan, to grow, wëg, way, wësan, to be. It became the labiodental spirant $\mathbf{v}$ (written $\mathbf{w})=$ Engl. $\mathbf{v}$ in vat, in late MHG., and this has remained in NHG., as wachsen, weg; \&c. w must have become a spirant in Bavarian before the end of the thirteenth century, because in this dialect $b$ $(=$ Germanic $\mathbf{b})$ and $\mathbf{w}$ had the same value, that is, $\mathbf{w}$ was written for Germanic $\mathbf{w}$ and $\mathbf{b}$ and vice versa. Initial $\mathbf{w}$ had disappeared before $1, \mathrm{r}$ in prehistoric OHG., as OHG. ant-luzzi, Goth. wlits, face, countenance; OHG. rëhhan, Goth. wrikan, to persecute.

$\S 230$. $\mathbf{w}$ had disappeared before $\mathfrak{u}$ in prehistoric OHG. (§ 208), as pp. gidungan beside inf. dwingan, to force; it also regularly disappeared before OHG. uo $=$ Germanic $\overline{0}$, as OHG. suozi, OE. swēte, sweet; huosto, $\mathrm{OE}$. hwōsta, cough; pret. suor, OE. swōr, he swore. The $\mathrm{w}$ was often restored by analogy from forms where $\mathbf{w}$ was regular, as OHG. swuor beside suor, inf. swerien, pp. gisworan.

\$231. In the NHG. combinations schw·, zw., qü, we have the bilabial instead of the labiodental spirant, which by many people is pronounced voiceless, as schwester, schwarz, zwei, zwingen, quelle, quer, \&c. In other cases 
NHG. w is labiodental, as ewrig (MHG. ēwic), löwe (MHG. lěwe), witwe (MHG. witewe).

\$232. ww was treated differently according as it was general Germanic ww (= Gothic ggw) or West Germanic ww from wj ( $\$ 213)$.

I. General Germanic aww >auw > ouw which became ou when final, as OHG. inflected form glauwēr, glouwēr, clear, exact, uninflected form glau, glou, beside Goth. glaggwō, exactly, diligently; OHG. hauwan, houwan, to hew = Goth. *haggwan.

General Germanic eww > iuw which became iu when final, as OHG. bliuwan = Goth. bliggwan, to strike, triuwi = Goth. triggws, true, faithful; spriu, chaff, pl. spriuwir ; iu dat. pl. to ir, $y e$.

General Germanic uww $>\bar{u} w$, as OHG. scūwo $=$ Goth. skuggwa, shade, shadow.

2. West Germanic ww from wj. In this case aww > auw > ouw, as frauwa, frouwa, woman, from *frawjō. ; frouwen, to rejoice, from ${ }^{*}$ frawjan, beside pret. sing. frewita from *frawita $(\$ 60)$. The interchange between West Germanic ww (from wj) and wi gave rise to many new formations in OHG. and MHG., as.OHG. frewen, MHG. fröuwen (beside the regular form frouwen), which were formed after the analogy of the pres. second and third pers. sing. frewis, frewit ( $\$ 213)$, and the pret. frewita. Similarly in MHG. döuwen, to digest, drö uwen, to threaten, ströuwen, to strew, beside the regular forms douwen, drouwen, strouwen. Also in nouns: regular forms were MHG. nom. heu, höu (= Goth. hawi, OHG. hewi), hay, gen. houwes, dat. houwe, from which a new nom. houwe was formed. Similarly in MHG. nom. gouwe, NHG. gau, beside the regular MHG. forms geu, göu = OHG. gewi.

iww from original ewj became iuw, as OHG. siuwen from *sewjan, to sew, cp. OE. sēowian, Goth. siujan; niuwi from "newja., cp. Goth. niujis, new. 
$\$ \$ 233^{-6]}$ The High German Consonants I 2 I

§ 233. OHG. and MHG. a w has become au in NHG., as OHG. and MHG. gen. blāwes, grāwes = NHG. blaues, graues; OHG. brāwa, klāwa, pfāwa, MHG. brāwe, klāwe, pfāwe = NHG. braue, klaue, pfau.

§ 234. MHG. intervocalic $w$ has disappeared in NHG. when the first vowel was $\overline{\mathrm{u}}, \overrightarrow{\mathrm{u}}$ or one of the diphthongs ou, öu in MHG., as MHG. būwen, trūwen, NHG. bauen, trauen, see §128. MHG. iuwer, niuwe, riuwe, pl. siuwe, triuwe, NHG. ener, neu, rene, säne, trene. MHG. frouwe, houwen, ouwe, schouwen, NHG. frau, hauen, aue, schauen. MHG. fröuwen, ströuwen, NHG. freuen, streuen.

§ 235. MHG. $\mathbf{w}$. has become $\mathbf{b}$ after 1 and $\mathbf{r}$ in NHG. This change had taken place in the Swabian dialect by the end of the thirteenth century. Examples are: albern (MHG. alwære), falb (MHG. val, gen. valwes, NHG. fahl is the old nom.), gelb (MHG. gël, gen. gëlwes), milbe (MHG. milwe), schwalbe (MHG. swalwe), erbse (MHG. ärwiz), farbe (MHG. varwe), gerben (MHG. gerwen, to prepare), mürbe (MHG. mürwe), narbe (MHG. narwe), sperber (MHG. sparwære, sperwære).

§236. In OHG. single $w$ became vocalized to $o$ if it came to stand at the end of a word or syllable, as balo (gen. bal(a)wes), wickedness; falo (infl. falwēr), fallow'; garo (inflected form gar(a)wēr), ready; garwen (pret. garota), to prepare; gëlo (infl. gëlwēr), yellow; kneo (gen. knëwes), knee; mëlo (gen. mëlwes), meal; smëro (gen. smërwes), fat; scato (gen. scat(a)wes), shade, shadow.

blāo (infl: blāwēr), blue; fao (infl. fawēr), little; frao (infl. frawēr), joyful; grāo (infl. grāwēr), grey; klēo (gen, klēwes), clover; rao (infl. rawēr), raw; sēla from *sēola $=$ Goth. sáiwala, soul; sēo (gen. sēwes), sea; snēo (gen. snēwes), snow ; pret. spēo, inf. spiwan, to vomit ; strao (gen. *strawes), straw.

The final o was dropped after long vowels in the ninth 
century, hence OHG. and MHG. blā, grā, klē, sē, snē, beside gen. blāwes, grāwes, klēwes, sēwes, snēwes. In passing from MHG. to NHG. the inflected forms with w have been generalized in blau, grau; in klē, sē, snē, the nom. forms have been generalized, as $\operatorname{see}(e) s$, \&c.

The final ao became $\overline{0}$ in OHG., whence OHG. and MHG. frō, rō, strō. In passing from MHG. to NHG. the nom. has been generalized, as froh, gen. frohes, \&c.

The final o was weakened to e in late OHG. and was then dropped after liquids in MHG., as gël, mël, val, gar, smër ( $\$ 171)$. gar has remained in NHG. as an uninflected particle ; in fahl, mehl, schatten the nom. has been general. ized, but in falb and gelb the inflected forms have been generalized.

Final eo became ie in late OHG., whence MHG. knie, gen. knëwes; in NHG. the nom. form has been generalized.

$\S 237$. When $\mathbf{w}$ was introduced by analogy or levelling into a final position, it has become $b$ in NHG., as MHG. houwen, to hew, pret. sing. hie (OHG. hio), pl. hiewen, from which a new pret. sing. hiew was formed = NHG. hieb, cp. also the noun hieb, and wittib beside witwe. This sound-change is also common in the modern South and Middle Franconian dialects, as leb = literary German löwe, and in some Alemanic dialects, as blāb=literary German blau.

\section{j}

\$238. The Indg. palatal spirant $\mathbf{j}$ and $\mathbf{i}$ consonant, written $\mathbf{j}$ in this book, fell together in $\mathbf{i}$ consonant in prim. Germanic. i consonant was written $\mathbf{i}$ (rarely e, g) in OHG. manuscripts.

Initial Germanic $\mathbf{j}$ has, with few exceptions, remained through all periods of HG., as OHG. jāmar, jār, joh, jugund, jung $=$ NHG. jammer, jahr, joch, jugend, jung. 
§§239-40] The High German Consonants I 23

$\mathbf{j}$ became a spirant (written $\mathbf{g}$ ) before e, $\mathbf{i}$ in $\mathrm{OHG}$., as gëhan, to confess, pres. sing. gihu, gihis, gihit, beside pret. sing. iah, pl. iāhun. This $\mathbf{g}$ became an explosive in those dialects which had the old spirant $3(\S 218)$ in OHG.; hence NHG. gären (OHG. jerian, gerian), gischt (MHG. jëst, gëst), and gäten beside jäten (MHG. jëten, gëten). Initial $\mathbf{j}$ has become an explosive before other vowels in some modern Middle German dialects, as gahr, gung = literary German jahr, jung.

$\$ 239$. $\mathbf{j}$ disappeared medially before $\mathbf{i}$ already in West Germanic; hence verbs which had double consonants in the inf. by the West Germanic doubling of consonants (\$ 213) have only a single consonant in the second and third pers. of the present indic., as OHG. inf. bitten, to beg, liggen, to lie down, leggen, to lay, zellen, to say, beside bitis, bitit; ligis, ligit; legis, legit; zelis, zelit. In MHG. this distinction was partly given up through generalizing one or other of the forms, as biten, legen, ligen, zeln, beside bitten, leggen, liggen, zellen. In NHG. the distinction has entirely disappeared, so that in some verbs the forms with double consonants, and in other verbs the forms with single consonants, have been generalized, as brennen, bitten, küssen, stellen; dehnen, legen, liegen, zählen.

After consonants (except $\mathbf{r}$ ) medial $\mathbf{j}$ became reduced to a mere vocalic glide, written e, $i$, in the oldest HG. This glide disappeared in the ninth century, as heffiu = Goth . hafja, I raise, dat. kunnie =Goth. kunja, to a race, sippia, sippea $=$ Goth. sibja, peace, relationship, willio $=$ Goth . wilja, will, became heffu, kunne, sippa, willo.

$\$ 240$. $j$ in the combination rj regularly became a spirant, in OHG. or early MHG., which would have become $\mathbf{g}$ in NHG. (\$238). A few such forms have remained in NHG., as ferge (OHG. ferio), latwerge (MHG. latwerge, latwērje), scherge (OHG. scerio, MHG. scherge, scherje). In other words, where we should expect $\mathrm{rg}$ in NHG., those 
forms have been generalized where the $\mathbf{j}$ had become $\mathbf{i}$ (finally) or had disappeared already in prehistoric $\mathrm{HG}_{\text {., }}$ thus the regular form is heer (=OHG. heri), on the model of which the gen. heer $(e) s$, dat. heer $(e)$, have been formed for *herges, *herge ; nähren (OHG. nerien) for *närgen, after the analogy of the second and third pers. sing. pres. indic. (OHG. neris, nerit) and the pret. (OHG. nerita).

$\$$ 241. Prim. Germanic $\mathrm{jj}$ became ddj in Gothic and ggj, gg in O.Icel. In OHG. ajj became eij, and $\mathrm{ijj}$ became $\overline{i j}$, as gen. Goth. twaddjē, O.Icel. tveggja, OHG. zweiio, later zweio, of two; O.Icel. egg, OHG. ei from *aijaz, egg; proper name O.Icel. Frigg, OHG. Fri(i)a.

$\$ 242$. In the verba pura, forms with and without a developed glide (written $\mathrm{j}$ ) existed side by side in OHG. and MHG. In NHG. the glide has disappeared (cp. $\$ 280$ ). Examples are: OHG. bluojen, drājen, muojen, sājen = MHG. blüejen, dræjen, müejen, sæjen, beside OHG. bluoen, drāen, muoen, sāen = M HG. blüen, dræn, müen, sæn, NHG. blühen, drehen, mühen, säen.

§243. Final -jan became -en, but -jen when preceded by $\mathbf{r}$, as OHG. heffen = Goth. hafjan, to raise; OHG. nerien $=$ Goth. nasjan, to sav'e.

Final $\mathbf{j}$ became $\mathbf{i}$ in prehistoric $\mathrm{HG}_{\text {., }}$ as betti (Goth. badi, gen. badjis), bed; kunni (Goth. kuni, gen. kunjis), race, generation; nezzi (Goth. nati, gen. natjis), net; and similarly in hirti, shepherd, festi, fast, scōni, beautiful, \&c. The regularly developed forms of the nom. of betti, kunni, nezzi, and similar forms with double consonants in the nom., would be *beti, *kuni, "nezi. The double consonants have been introduced into the nom. by levelling out the inflected stem forms.

When $\mathbf{j}$ came to stand finally in historic times it became a spirant, as NHG. eppich (M HG. epfĭch, epfe, from Lat. apium); käfig (MHG. kevje, from late Lat. cavia, cavea); mennig (M HG. menig, from Lat. minium). 
THE Liquids.

1

§ 244. Germanic 1 remained unchanged in $H G$., as OHG. alt, blint, kalb, fëld, haltan, lamb, lëbēn, mëlo, stellen, waltan, wollen $=$ NHG. alt, blind, kalb, feld, halten, lamm, leben, mehl, stellen, walten, wollen. On vocalic 1 in NHG. edel, vogel, himmel, nagel, \&c., see § 175.

\section{$\mathbf{r}$}

\$245. Germanic $\mathbf{r}$ has generally remained in HG., as OHG. arm, bërg, brennen, dorf, dringan, faran, friunt, grab, meri, rātan, wërdan = NHG, arm, berg, brennen, dorf, dringen, fahren, freund, grab, meer, raten, werden. On the vocalic $\mathbf{r}$ in NHG. bitter, vater, \&c., see $\$ 175$.

Final $\mathbf{r}$ disappeared in monosyllables after long vowels in late OHG. of the eleventh century, as dā, wā, è, hie, older dār, wār, èr, hiar; whence NHG. da, wo, beside darin, worin; hierunter beside hienieden; che beside eher.

Note.-OHG., MHG., and early NHG. $\mathbf{r}$ was the front or point trill $\mathbf{r}$ as in modern Scotch. This $\mathbf{r}$ began to give way to the back or uvular $\mathbf{r}$ in the eighteenth century. In modern times it has spread extensively in towns and North Germany. Its origin in Germany was probably due to the imitation of French pronunciation. It arose in France about the middle of the seventeenth century and rapidly became common in the language of refined society.

\section{The Nasals.}

m

\$246. Germanic $\mathrm{m}$ has generally remained unchanged in HG. initially, medially, and also finally in monosyllables, as OHG. machōn, meri ; fremidi, himil, namo, nëman, 
swimman; arm, heim, nim = NHG. machen, meer; fremd, himmel, name, nehmen, schwimmen; arm, heim, nimm.

Germanic medial -mp- became -mft- through the intermediate stage of $\cdot \mathrm{mfp}$. in prehistoric $\mathrm{HG}$. $\cdot \mathrm{mft}$ - then became -nft- during the OHG. period, as OHG. and NHG. brunft: OHG. brëman, to roar, bellow; OHG. kunft, NHG. zukunft, künftig: OHG. quëman, NHG. kommen; OHG. nunft, a taking, NHG. vernunft, vernünftig: OHG. nëman, NHG. nehmen; OHG. and NHG. zunft: OHG. zëman, NHG. ziemen. And $\mathrm{mf}$ became $\mathrm{nf}$, as OHG. finf, older fimf, NHG. fünf.

Final $\cdot m$, when an element of inflexion, became $\cdot n$ in the course of the ninth century, as dat. pl. tagum, gestim, blintēm, dēm; bim, I am, habēm, I have, mahhōm, $I$ make, nāmum, we took, became tagun, gestin, blintēn, dēn; bin, habēn, mahhōn, nāmun. The final $\cdot \mathbf{n}$ in the first pers. sing. pres. indic. of weak verbs, Class II and III, mahhōn, habēn, was dropped in the MHG. period after the analogy of the strong verbs and weak verbs, Class I. In other cases final $-\mathbf{n}$ when an element of inflexion has generally remained in NHG., as tagen, blinden, nahmen, \&c.

In late MHG. and early $\mathrm{NHG}$. final $\cdot \mathrm{m}$, when not an element of inflexion, became $\cdot \mathbf{n}$ in words of more than one syllable, as MHG. bësem(e), bodem, buosem, vadem, gadem $=$ NHG. besen, boden, busen, faden, gaden beside gadem. Forms like atem, eidam, gadem, odem, oheim have their $-m$ from the inflected forms; thus regular forms were MHG. āten, gen. ātem(e)s, dat. ātem(e). In Alemanic final $\cdot m$ became $\cdot n$ in monosyllables also, as heim, ruom became hein, ruon.

$\mathbf{n}$

$\S 247$. Germanic $\mathbf{n}$ has generally remained unchanged in all periods of the $\mathrm{HG}$. language, as OHG. nagal, nëman, niun ; bintan, findan, senten, uns ; brennen, biginnan ; 
rëgan, sibun, stein, dīn; pl. zungūn, acc. sing. blintan, in, dën, wën = NHG. nagel, nehmen, neun; binden, finden, senden, uns; brennen, beginnen; regen, sieben, stein, dein; zungen, blinden, ihn, den, wen. See \$175. Forms in which final inflexional $\cdot \mathbf{n}$ has disappeared in NHG. will be treated in the Accidence, as gen. dat. acc. sing. OHG. zungūn, MHG. zungen, NHG. zunge. In MHG. $n$ became $\mathrm{m}$ before labials by assimilation, as MHG. an(e)bōz, enbor, einber, hin(t)ber (cp. Engl. dial. hindberry), inbĭz, win(t). brā(we), became ambōz, embor, eimber, himber (himper), imbǔ̆z, wimbrä; whence NHG. amboss, empor, eimer, himbere, imbiss, wimper.

Similarly in the NHG. prefix ent., the $\mathbf{t}$ became $\mathbf{p}$ before a following labial, and then enp- became emp., as in empfangen, empfehlen, empfinden. Forms like entbehren (MHG. embërn), entfallen, entfremden, are new formations.

$\$ 248$. $\mathbf{n}$ has disappeared by assimilation in eiland, older einland, elf (MHG. eilf, einlif), siebzehn, -zig, beside sieben.

$\mathbf{n}$ has disappeared in an unstressed syllable when preceded by $\mathbf{n}$ in a stressed syllable, as MHG. minenthalben, -wëgen, NHG. metnethalben, -wegen; similarly in deinet-, seinet-; then after the analogy of these also euret., ihret. MHG. swinin-fleisch = NHG. schweinefleisch.

$\S 249$. The $\mathrm{n}$ in MHG. sunst (NHG. sonst) beside sus, sust is probably of Alemanic origin, where stem vowels, especially when long, were nasalized before s, as funst, linse, NHG. faust, leise.

\$250. The Germanic guttural nasal $\boldsymbol{\eta}$ (written $\mathfrak{n}$ ) only occurred medially before $\mathbf{g}$ and $\mathbf{k}$.

It has remained before $\mathbf{k}$ in all periods of the $H G$. language, as $\mathrm{OHG}$. dankōn, denken, sinkan, trinkan; 
bank, dank = NHG. danken, denken, sinken, trinken ; bank, dank.

Intervocalic $\eta \mathrm{g}$ (as in Engl. finger, not as in NHG. finger) remained in OHG. and $\mathrm{MHG}$, but has become $\boldsymbol{\eta}$ (written $\mathbf{n g}$ ) in NHG., as OHG. bringan, fingar, hungar, singan, zunga $=$ NHG. bringen (= brinən), finger, hunger, singen, zunge.

In final stressed syllables $\mathrm{ng}$ became $\mathrm{\eta k}$ in $\mathrm{MHG}$., as MHG. dinc, junc, lanc, beside gen. dinges, junges, langes; pret. sing. sanc beside pret. pl. sangen. This final $\mathbf{~} \mathbf{k}$ sound has been retained in NHG. in the dialects-often also amongst educated people-of a great part of North and North Middle Germany. On the other hand the intervocalic form $\boldsymbol{y}$ has been generalized in the recognized standard language and in the dialects of South and South Middle Germany.

The guttural $\boldsymbol{y}$ disappeared in an unstressed syllable when preceded by $\mathbf{n}$ in a stressed syllable in the course of the OHG. and MHG. period, as OHG. honag beside honang, NHG. honig; OHG. kunig, MHG. künic, beside OHG. kuning, NHG. könig; OHG. pfennig, MHG. pfennic, beside OHG. pfenning, MHG. pfenninc, NHG. pfennig.

The $\eta$ has disappeared in the secondary stressed syllable of $\mathrm{NHG}$. verteidigen $=\mathrm{MHG}$. verteidingen, older vertagedingen.

\section{The LABials.}

p

\$251. The history of Germanic $\mathrm{p}$ in OHG. has already been given in $\S 217$. Germanic $p$ only remained unshifted in the combination sp, as OHG. spinnan, spizza, sprëchan $=$ NHG. spinnen, spitze, sprechen.

The pf, which arose from Germanic p, pp, has generally 
remained in all periods of $\mathrm{HG}$., as OHG. pfad, pfëffar, pflëgan; charpfo, kuphar, opfar, skephen, tropfo; kamph, knopf = NHG. pfad, pfeffer, pflegen; karpfen, kupfer, opfer, schöpfen, tropfen; kampf, knopf.

pf, from Germ. single $p$, became $f$ after 1 and $r$ in the ninth century, as hëlfan, dorf, wërfan, beside older hëlpfan, dorpf, wërpfan, NHG. helfen, dorf, werfen. In OHG. harfa, MHG. harfe, beside OHG. harpfa, MHG. harpfe; OHG. scarf, MHG. scharf, beside OHG. scarpf, MHG. scharpf there existed in prehistoric times forms with single and forms with double p. The forms which originally had single $\mathrm{p}$ have survived in NHG.

$\$ 252$. From what has been said in $\$ 251$ it follows that all words beginning with $\mathbf{p}$ and not pf in NHG. must be either from Middle and Low German, Latin, the Romance languages, or from words which began with $\mathbf{p}$ beside $\mathbf{b}$ in OHG. ( $\$ 218)$. The interchange between $\mathbf{p}$ and $\mathbf{b}$ initially and medially disappeared in Upper German in the twelfth century except that $\mathbf{p}$ frequently occurred initially through. out the Middle Ages in Bavarian.

Early loan-words with initial $\mathbf{p}$ were written $\mathbf{p}$ and $\mathbf{b}$ in MHG. and early NHG., as pābes $(t$, pate, pëch, beside bābes(t (Lat. pāpa), bate (Lat. pater), bëch (Lat. acc. picem); and similarly in palme, pedell, pin, pelz (older belliz, Low Lat. pellicia), përle, pilger, plage, predigen, pris (O.French pris), prisen, priester, prüeven, puppe, \&c. Such words now have $p$ in NHG., due to the influence of Middle German where initial $\mathbf{p}$ and $\mathbf{b}$ were kept apart in sound.

Romance words borrowed in late MHG. and early NHG. were generally written with $\mathrm{p}$, but also sometimes with $\mathbf{b}$, they too always have $\mathbf{p}$ now, as paar, palast, pantoffel, papier, partei, passen, pause, pest, pille, plan, prinz, pulver, \&c.

Examples of Middle and Low German words, some of 
which had $\mathbf{p}$ beside $\mathbf{b}$ in early NHG., but which now have always p, are: pack, pacht (the MHG. form is pfaht), papagei, pegel, piepen, pinsel, platt, plump, plunder, pochen, pocke, prahlen, \&c.

b

§253. The chief points concerning the history of Germanic $b, b, b b$ have already been given in $\$ 218$. Further examples of $b$ in OHG. and NHG. are: OHG. bein, bintan, bitten; blat, brief, bruoder; ëban, gëban, gilouben, habēn, sibun, trïban, ubil, erbi ; diob, grab, halb, kalb, liob = NHG. bein, binden, bitten; blatt, brief, bruder; eben, geben, glauben, haben, sieben, treiben, übel, erbe; dieb, grab, halb, kalb, lieb. $\mathrm{b}$ has become $\mathrm{p}$ before $\mathbf{t}$ in haupt = MHG. houbet. NHG. has generalized the uninflected form in alp, gen. alpes (MHG. alp, gen. albes).

$\S 254$. A small number of words, chiefly loan-words, which originally had initial $b$, were written $p$ or $b$ in MHG. and early NHG. These now have $p$, as panier (MHG. panier, banier, French bannière); pilz (MHG. builz, builez, OHG. buliz, Lat. bōlētus) ; pracht (OHG. and MHG. praht, braht) ; prägen (MHG. præchen, bræchen, OHG. brāhhen); prasseln (MHG. prasteln, brasteln, OHG. *brastalōn); polster (MHG. polster, bolster, OHG. bolstar).

$\$ 255$. By about the middle of the fifteenth century, initial $\mathbf{b}$ had become a lenis in some East Middle German dialects. This gave rise to $p$ being written for $b$, just as it had done at a much earlier period in Upper German (\$219). In Luther's early writings about forty words have $\mathrm{p}$, which in his later works have $\mathrm{b}$, as peycht, prauchen, gepeet, peste, prechen, fruchtpar = beichte, brauchen, gebet, beste, brechen, fruchtbar.

$\$$ 256. Medial $\mathrm{mb}$ became $\mathrm{mm}$ in late $\mathrm{MHG}$. and early 
$\S \S 257-8]$ The High German Consonants I $3 \mathrm{I}$

NHG. $\mathrm{mm}$ then came to be used finally by levelling out the medial form, as amt (MHG. ammet, ambet); dumin (MHG. tump, gen. tumbes, tummes); lamm (MHG. lamp, gen. lambes, lammes); eimer (MHG. eimber, § 247); and similarly in hummel, imme, kamm, klimmen, krumm, kummer, schlimm, stumm, stummel, trommel, um (MHG. umbe), wamme, zimmer.

Note.-In early NHG. a $b(p)$ was often written after $m$, as eigentumb, kaumb, allesampt, frembdling, verdampten, but all such forms have now disappeared.

\$ 257. West Germanic bj became bb in Franconian and pp in Upper German ( $\$$ 218). This bb became pp in Upper Franconian during the OHG. period. NHG. has pp in all such words, e.g. krippe, rippe, sippe, üppig.

\$258. Germanic f from Indg. $\mathbf{p}$ (\$ 192) occurred initially, medially, and finally. In the oldest HG. it was bilabial like Gothic $\mathrm{f}$, but during the OHG. period it became labiodental, as is shown by the change of $m$ to $n$ before $f(\$ 246)$. It was often written $\mathbf{v}$ initially, and generally medially between vowels, but always $f$ finally. Already in OHG. it became a lenis initially, and medially between voiced sounds, but remained a fortis when final.

OHG. $\mathrm{f}$ from Germanic $\mathrm{p}$ ( $\$ 217$ ) only occurred medially between vowels and finally after vowels, later after 1 and $\mathbf{r}$ also ( $\$ 251)$. It was a labiodental fortis and always written $f(f f)$ in all periods of the language.

The two $f$ sounds fell together at an early period when final. The distinction between the two sounds was still preserved in MHG. in the intervocalic position, as hof, schif, but gen. hoves, schiffes. In NHG. they have also fallen together when medial, as MHG. nëve, zwivel = NHG. neffe, zweifel; MHG. loufen, trëffen = NHG. 
laufen, treffen. frevel (MHG. vrevel) is now the only word in which Germanic $f$ is written $\mathbf{v}$ medially. Initially $f$ and $v$ are used in NHG. without any definite rule. Examples of Germanic $\mathbf{f}$ in NHG. are: vater, fallen, fahren, vuel, feuer, fleisch, vogel, volk, von, freund, voll, fülle, vor, für, fürchten; neffe, teufel, zweifel; kraft, luft; brief, elf, hof, wolf. Examples of OHG. $\mathbf{f}$ from older $\mathbf{p}$ are: greifen, kaufen, laufen, rufen, schlafen, saufen, taufen, treffen, haufe; tief, schiff.

\$259. In Middle and Low Franconian $\mathrm{ft}$ became $\mathrm{ht}=$ cht in the MHG. period, as haht, kraht, luht $=$ NHG. haft, kraft, luft. Several such words have got into the NHG. literary language at various times, as berüchtigt (related to NHG. mufen); beschwichtigen (related to MHG. swiften, to silence); echt (MHG. èhaft, according to law); gerïcht (MHG. gerüefte); nichte (MHG. niftel); sacht (MHG. sanfte, NHG. sanft); schacht beside NHG. schaft; schlucht beside early NHG. schluft; sichten (MHG. siften).

\section{The Dentals.}

$\$ 2$ 260. In the combinations $\mathbf{t r}, \mathbf{h t}$, ft, st Germanic $\mathbf{t}$ has remained in all periods of the $\mathrm{HG}$. language, as $\mathrm{OE}$. tredan, OHG. trëtan, NHG. treten; Goth. baitrs, OHG. bittar, NHG. bitter (\$214); Goth. wintrus, OHG. wintar, NHG. winter; OE. niht, OHG. naht, NHG. nacht; OE. dohtor, OHG. tohter, NHG. lochter; OE. cræft, HG. kraft ; OE. gāst, stān, NHG. geist, stein.

$\$ 2$ 261. Apart from the $t$ in the above combinations, Germanic $\mathbf{t}$ was shifted in prehistoric OHG. to the affricata $t z$, initially, medially and finally after consonants $(1, \mathrm{~m}, \mathrm{n}, \mathrm{r})$, and when doubled ( $\$ 217)$. In OHG. and early MHG. the affricata was really $\mathrm{t} z$ which became ts in late 
\$262-3] The High German Consonants 133

MHG., although the writing $t z$ has been retained in NHG. medially between and finally after short vowels. The affricata has remained in all periods of the HG. language. In OHG. it was written $\mathbf{z}$ initially, as OHG. zit = NHG. zeit; medially and finally after long vowels, diphthongs, and consonants, as OHG. krūzi, reizen, hërza, holz = NHG. kreuz, reizen, herz, holz; medially after vowels when it ended a syllable, as sazta, pret. of setzen ; and finally after vowels when it corresponded to Germanic tt, as OE. sceatt, OHG. scaz, treasure ( $\$ 217$ ).

Medially between short vowels, where it corresponded to Germanic tt or West Germanic tt from tj (§ 213), it was generally written $\mathbf{z z}$ in early OHG. and $\mathbf{t z}$ in late OHG., as OE. sittan, OHG. sizzen, sitzen; scaz but gen. scazzes, scatzes; OE. settan, OHG. sezzen, setzen.

\$262. In M HG. tz was regularly used medially between short vowels, but $\mathbf{z}$ in all other positions. In NHG. $\mathbf{z}$ is used initially, medially and finally after diphthongs and consonants; and $\mathrm{t} z$ is used medially between and finally after short vowels.

Examples are: OHG. zëhan, zït, $\mathbf{z w e l i f ,} \mathbf{z w i f a l}=\mathrm{NHG}$. zehn, zeit, zwölf, zweifel; OHG. beizen (from *baitjan), krūzi, heizen, (MHG. kūze, kūz), reizen, weizi = NHG. beizen, kreuz, heizen, kauz, reizen, weizen; OHG. hërza, holz, kurz, ganz, lenzo, merzo, salz, smërza, smërzan, wurzala, sturzen, swarz = NHG. herz, holz, kurz, ganz, lenz, Mörz, salz, schmerz, schmerzen, wurzel, stïrzen, schwarz; OHG. hitza, katza, nutzi, setzen, sitzen, spitza = NHG. hitze, katze, nütze, setzen, sitzen, spitze ; OHG. antlutzi, netzi, scaz, witzi = NHG. antlitz, netz, schatz, witz.

§263. Germanic single $\mathbf{t}$ was shifted to the double voiceless spirant 33 medially between and finally after vowels (\$217). The 33 was simplified in OHG. to 3 medially after long vowels, and finally (\$ 223). The double 
spirant and the single spirant were generally written $\mathbf{z z}, \mathbf{z}$ in OHG. manuscripts, but zss in Isidor, written in the Rhenish Franconian dialect of the end of the eighth century. In OHG. and MHG. grammars the spirants, which were a kind of lisped $\mathbf{s}$, are generally written 33,3 in order to distinguish them from the affricatae, $\mathbf{z z}, \mathbf{z}$. In the fourteenth century the spirant began to be written sz, whence the NHG. writing if. In NHG. it is written if after long vowels, diphthongs, and finally, but $\tilde{\pi}$ after short vowels. In Latin characters it is written ss (formerly also sz) medially, and also finally when related inflected forms exist side by side, as hass, gen. hasses, but when no related inflected forms exist it is written $\mathrm{s}$, as aus, bis, das, was, es, gutes (neut. nom.), \&c.

The spirant 33,3 has generally remained voiceless in all periods of the HG. language. The early MHG. good poets did not rhyme laz, wizzen with las, missen.

Final $\mathbf{z}$ became $\mathbf{s}$ and fell together with Germanic final $s$ in the thirteenth century. The NHG. orthographical distinction between $\mathbf{s s}(=z)$ and $\mathbf{s}=$ Germanic $\mathbf{s}$ is due to Middle and Low German influence, as hass but las (he read).

Medial intervocalic 33,3 became a voiceless fortis $\mathbf{s}$ during the fourteenth century, but it did not fall together with Germanic medial intervocalic s, which was a voiceless lenis ( $(293)$. Examples are: OHG. bezziro, biz(z)an, drīz(z)ug, ëzzan, gazza, gruoz(z)en (MHG. grüezen), ginōz, haz̧̄en, lāz(z)an, mëzzan, rīz(z)an, waz̧ar, wiz̧an = NHG. besser, beissen, dreissig, essen, gasse, grïssen, genosse, hassen, lassen, messen, reissen, wasser, wissen; OHG. āz, biz, faz, fliz, fuoz, haz, heiz, nuz, suoz(z)i (MHG. sïeze), $\overline{\mathrm{u}}$, wīz = NHG. ass, biss, fass, fleiss, fuss, hass, heiss, nuss, süss, aus, weiss.

$\S 264$. MHG. 3 is written with voiceless $s$ in $\mathrm{NHG}$. feist (MHG. veizet), kïrbis (MHG. kürbiz), gen. kürbisses, 
obst (MHG. obez), Samstag (MHG. samztag, OHG. sambaztag).

It has fallen together with Germanic $\mathbf{s}$ and has therefore become voiced medially between voiced sounds in NHG. ameise (MHG. āmeize), binse (MHG. binez), and similarly in emsig, gemse, kreisen, verweisen; erbse; gesims (MHG. simez), and similarly in krebs, kreis, los (Engl. lot), sims.

It has become sch after $\mathbf{r}$ (cp. $\$ 294$ ) in hirsch (MHG. hirz, OHG. hiruz).

\section{d}

$\$$ 285. Germanic d remained in OHG. initially and medially in Middle and Rhenish Franconian (but South RFr. $t$ medially). It became $t$ in all positions in Upper German and East Franconian. And it became $t$ finally in all dialects. dd was also shifted to tt in all dialects (\$ 218, 2).

§266. Upper German and East Franconian $\mathbf{t}$ has remained in NHG. initially, as E.Fr. tag, tāt, teilen, tiufal, tohter, tragan, trinkan $=\mathrm{NHG}$. tag, tat, teilen, teufel, tochter, tragen, trinken. But initial tw became $\mathbf{z w}$ in the fourteenth century, as OHG. twërg, late MHG. zwërc, NHG. zwerg.

Note.-In NHG. a certain number of words have initial d, which in MHG. had $\mathbf{t}$ or $\mathbf{d}$ beside $t$. Some of the words are of Latin or French origin, as dauern (Lat. durare), dichten (Lat. dictare), drache (Lat. draco), dutzend (MHG. totzen, Fr. douzaine), \&c. The initial $d$ in such cases is due to association with the original forms of the words. In the other words the d is due to the influence of Middle or Low German. The following is a fairly complete list: damm,dampf, dauern, to grieve, da'ern, to last, dichten, dill, docke, dohle, dolde, dotter, drache, ducken, duft, dumm, dunkel, dung, dunst, dutzend; and in older NHG. dinte beside tinte.

$\S 267$. Upper German and East Franconian intervocalic 
$t$, tt have remained in NHG., as OHG. bëtōn, biotan, boto, fater, knëtan, muoter, rïtan, watan ; betti, bitten, mitti = NHG. beten, bieten, bote, vater, kneten, mutter, reiten, waten; bett, bitten, mitte.

\$268. Medial nt from Germanic nd became nd again in late OHG. and early MHG., and has remained as nd in NHG., as early OHG. bintan, senten, gen. lantes = late OHG., MHG., and NHG. binden, senden, landes; similarly in MHG. and NHG. hundert, schande, sonder (MHG. sunder), standen, stunde, wenden, winden, wunder, \&c. MHG. bant, gen. bandes ; hant, pl. hende $=$ NHG. band, bandes; hand, hände with final $\mathrm{d}$ from the inflected forms; similarly in blind, feind, freund, hund, land, rand, wind, \&c. But nt occurs in hinten, hinter, beside hindern, munter, unten, unter, probably due to the influence of the Bavarian dialect.

In NHG. the pret. of weak verbs whose stem ends in a nasal or nd are all new formations, as räumte (MHG. rūmde), diente (MHG. diende), nannte (MHG. nande), sandte (MHG. sande), with te after the analogy of preterites like hörte, lebte, sagte, where te is regular. Similarly in trïumte, brannte, kannte, rannte, \&c. In like manner we have NHG. siebente, neunte, zehnte (M HG. sibende, niunde, zëhende) after the analogy of fiinfte, sechste, \&c.

$\$ 269$. OHG. medial and final 1t, rt from Germanic ld, $\mathrm{rd}$ have remained in all periods of the $\mathrm{HG}$. language, as OHG. alt, eltiron, haltan = NHG. alt, eltern, halten ; and similarly in alter, gelten, gewalt, kalt, schelten, schulter, seltsam, spalten, walten, \&c.

Id remained unshifted in East Middle German, and a few words with ld have got into the literary language from this dialect, as OHG. dulten, gelt, gen. geltes, milti = NHG. dulden, geld, geldes, mild; and similarly in geduld, geduldig, mulde, schild.

OHG. bart, fart, garto = NHG. bart, fahrt, garten ; 
\$270-72] The High German Consonants I 37 and similarly in hart, geburt, gürten, schwert, wort. NHG. herde (MHG. hërte) is from Low German herde.

$\S 270$. Final $d$ was shifted to $t$ in all the HG. dialects. The $\mathbf{t}$ has remained in all periods of the language, as OHG. blat, bluot, got = NHG. blatt, blut, gott; and similarly in brot (older NHG. also brod), haupt, tot, \&c. On forms like blind, feind, \&c., see above. NHG. kleinod (MHG. kleinōt), ried (MHG. riet), waid (MHG. weit) are from Middle German, with $\mathrm{d}$ from the inflected forms. NHG. niedlich (MHG. adv. nietliche) is probably also from the same source.

$\S 2$ 271. Final dt was often written for $t$ in early NHG., which was sometimes transferred to the medial position, as stadt : städte ; todt : tödten; bundt : bundtes. This dt is still used in stadt. In the preterites and past participles, sandte, wandte, gesandt, bewandt, gevuandt, verwandt, and in derivatives from them, as bewandtnis, gesandtschaft, gewandtheit, verwandtschaft, \&c., the $\mathrm{d}$ is due to the influence of the inf. senden, wenden.

\$272. In NHG. an excrescent $t$ has often been developed after $\mathbf{n}$, and spirants, rarely after other consonants. It is often written $\mathbf{d}$ after $\mathbf{n}$. Traces of the development of an excrescent $t$ began to occur in thirteenth-century MHG., as iergent, niergent, wilent, obezt, sust, saft, beside iergen, niergen, wilen, obez, sus, saf. Examples in NHG. are: allenthalben, dechant, eigentlich, flehentlich, freventlich, gelegentlich, geflissentlich, hoffentlich, namentlich, öffentlich, ordentlich, wesentlich, wissentlich, wöchentlich; dutzend, irgend, jemand, niemand, nirgend, weiland; and in the pronominal forms meine(n)t-, deine(n)t, seine(n)t-, unsere(n)t-, eure(n)t, ihre(n)t-halben, -weegen, see $\$ 248$; in entgegen (MHG. en.gegen), entzwei (M HG. en-zwei) the $\mathbf{t}$ may be due to the prefix ent.; and in gewolint (MHG. gewon) to the influence of past participles; axt, damast, einst, jetzt (MHG. ieze), morast, obst, palast, papst (pabst), 
sonst ; dickicht, dornicht, habicht, predigt, hüfte (MHG. huf, pl. hüffe), saft; anderthalb, sekt; in doppelt the $\mathbf{t}$ is due to the influence of verdoppelt.

$\$ 273$. A $\mathrm{d}$ has been developed between $\mathrm{n}-1, \mathrm{n}-\mathrm{r}$ in quendel (MHG. quëndel beside quënel), spindel (MHG. spinel), fähndrich, minder (MHG. minre), cp. the same development in English spindle, thunder.

\section{p}

\$274. Germanic $\mathrm{p}$ became $\mathrm{d}$ in Upper German about the middle of the eighth century, in Upper Franconian during the ninth century, in Middle Franconian and the North Middle German dialects in the tenth and eleventh centuries. So that by the end of the eleventh century $\mathbf{p}$ had become $d$ through the intermediate stage of d in all the HG. dialects. This $\mathrm{d}$ has generally remained initially and medially in the NHG. literary language (see $\$ 226$ ). Examples are: OHG.dah, decken, diutisc(MHG. generally tiutsch), diob = NHG. dach, decken, deutsch, dieb; and similarly in dulden, docht (Luther tocht), dorn, dorf, drei, dreschen.

In a small number of words NHG. has initial $\mathbf{t}$ for OHG. d. This is due to the influence of the Upper German dialects, in some of which Germanic $\mathrm{b}$ and $\mathrm{d}$ (older đ) fell together at an early date in the fortis $t$. The examples are: tauen (OHG. douwen), tausend (OHG. dūsunt), and similarly in tölpel, ton, tosen, traben, trümmer.

Initial $d w$ became $t w$ in late OHG. In the fourteenth century tw became $\mathbf{z w}$ in Upper German and $\mathbf{k w}$ (qu) in Middle German, as OHG. dwërh, twërh, late MHG. zwërh, quërh, NHG. zwerch - in compounds, as zwerchfell, -pfeife, -sack; related to NHG. quer (OHG. twër); OHG. dwingan, twingan, late MHG., NHG. zwingen.

In MHG. the def. art. daz was often weakened to $z$ and then became attached enclitically to the preceding word, 
$\$$ 275-7] The High German Consonants I 39

especially to prepositions; and similarly with the dat. dëme, as anz, inz, überz, ūfz, anme (ame, am), inme (ime, im) = NHG. ans, ins, iubers, aufs, am, im; also in NHG. vors, durchs, beim, vom, zum, zur.

Examples of the medial position are: OHG. bruoder, bilidōn (bildōn), findan, wërdan = NHG. bruder, bilden, finden, werden; and similarly in beide, gestade, odem, ruder, schneiden; wälder, bürde, erde, fordern, norden, vorder, würde; ander, künden. vierte (OHG. fiordo= $\mathrm{OE}$. fēorða) has te from the analogy of dritte, fiunfte.

\$275. In MHG. the medial lenis (d) became a fortis $t$, when it became final (\$ 226), as gen. tōdes, vëldes, mundes, wërdes, beside the nom. tōt, death; vëlt, field; munt, mouth; wërt, worth. NHG. has preserved this law in pronunciation, but has generalized the inflected stem form in the orthography except in wert which has generalized the nom. form. Other examples are: rad; bald, bild, gold, held, schuld, wald, wild; geschwind, vormund ; mord.

\section{The Gutturals.}

h

§276. The prim. Germanic spirant $\mathrm{x}$ from Indg. $\mathrm{k}$ (\$192) became an aspirate (written $h$ ) initially, and medially between vowels in prehistoric HG. (\$205). Xw became an aspirate medially between vowels in prehistoric HG., as $\mathrm{OHG}$. sëhan = Goth. saílvan, to see; and became $\mathrm{x}$ finally, as pret. $\mathrm{sah}=$ Goth. sahv; nāh $=$ Goth. nētu, near. But the spirant remained in OHG. medially before consonants $(\mathrm{s}, \mathrm{t})$ and after consonants $(1, \mathrm{r})$, when doubled (as OHG. hlahhen = Goth. hlahjan, to laugh), and when final.

§277. The aspirate $\mathrm{h}$ has remained initially before vowels in all periods of the HG. language, as OHG. habēn, hant, hëlfan, heim, hërza, hōren, horn = NHG. 
haben, hand, helfen, heim, herz, hören, horn. An inorganic $\mathbf{h}$ has been added by association with heissen in heischen (OHG. eiskōn $=$ OE. àscian), which occasionally occurs with $h$ in OHG. and MHG.

$\$ 278$. Initial $h$ disappeared before consonants $(\mathbf{l}, \mathbf{n}, \mathbf{r}, \mathbf{w})$ in the ninth century. Traces of the loss of $h$ in this position occur so early as the second half of the eighth century, as hlūt (OE. hlūd), hnuz (OE. hnutu), hring (OE. hring), hwaz (OE. hwæt), later lūt, nuз, ring, waz = NHG. laut, nuss, ring, was; and similarly in lahhen, louffan, neigen, reini, ros, rucki, wār, wëdar, wila, wër $=$ NHG. lachen, laufen, neigen, rein, ross, rücken, wo, weder, weile, wer.

$\$ 278$. Intervocalic $\mathbf{h}$ generally remained in OHG. The loss of $\mathbf{h}$ in this position, especially after short vowels, is common in eleventh-century Alemanic, as trān, zēn = trahen, tears, zëhen, ten. The loss of $\mathbf{h}$ and contraction of the two vowels regularly took place in the twelfth and thirteenth centuries in Middle German, especially in the West and North Middle German dialects, as hōst, māl, mān, stāl, sēn, \&c. = hōhest, mahel, māhen, stahel, sëhen. It became silent in all the dialects some time during the fourteenth century, although it has generally been retained in writing down to the present day. Examples are : ähre (MHG. äher, OHG. ahir), nahe (M HG. nāhe, OHG. nāho), sehen (MHG. sëhen, OHG. sëhan), gedeihen (MHG. dìhen, OHG. dỉhan), and similarly in erwähnen, fehde, vieh (OHG. fihu), gemahl, höhe, höher, leihen, mohn, stahl, zähre, zehn, ziehen, weihnachten (MHG. ze wihen nahten), \&c. The $\mathrm{h}$ has sometimes disappeared in writing, as beil (OHG. bỉhal), feile (OHG. fïhala), ton (M HG. tāhe), träne (MHG. pl. trähene).

$\$ 280$. The retention of the $h$ in the orthography in words to which it etymologically belonged served a useful purpose in late MHG. and early NHG., viz. as a sign 
\$281-2] The High German Consonants $14 \mathrm{I}$

of vowel-length. After short vowels had been lengthened in open syllables, as in MHG. sëhen, vihe, stahel = NHG. sehen, vieh, stahl (\$105), then on the analogy of such words the $\mathbf{h}$ began to be used in fourteenth-century Middle German as a sign of vowel-length in words which did not originally have it, irrespectively as to whether the vowel was originally long or short. This is the origin of the $\mathbf{h}$ after long vowels in the great majority of the cases in which it occurs. It is very common in Luther's works, and chiefly through the influence of his writings it has become extensively used in the NHG. literary language. Inorganic $\mathbf{h}$, as a sign of vowel-length, is now used finally after long vowels; between a long vowel and a following liquid or nasal; in verbs which were monosyllabic in MHG. or became so in early NHG., and which are now dissyllabic (\$181), as froh (MHG. vrō), früh, kuh; bahn (MHG. bane), fahren (MHG. varn), and similarly in hehlen, lahm, mühle, nehmen, sohn, stehlen, wählen, wohl, zahl, zahn, \&c. ; huhn (MHG. huon), jahr (MHG. jār), kïhl (MHG. küele), and similarly in lehren, mehr, ohr, sehr, wahr, \&c. ; blähen (MHG. blæjen, blæn), blühen (MHG. blüejen, blüen), and similarly in drehen, mähen, mühen, nähen; gehen (MHG. gēn), stehen (MHG. stēn). The only exceptions to this rule are draht (MHG. drāt), mahd (MHG. māt, gen. mādes), and naht (MHG. nāt), which have been influenced by the verbs drehen, mähen, nähen.

$\S 281$. In the combination $x^{t}$ the spirant has remained in all periods of the HG. language (written $\mathbf{h}$ in $\mathrm{OHG}$. and early MHG. ; from the fourteenth century onwards it is written ch), as acht (OHG. ahto, MHG. ahte), brachte (OHG. brāhta, MHG. brāhte), and similarly in dachte, fechten, fürchten, gesicht, licht, macht, nacht, recht, tochter, \&c.

$\S 282$. The combination $x s$, written hs in OHG. and

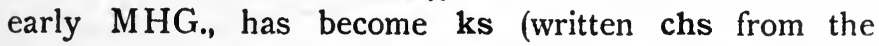
fourteenth century onwards) in NHG. It is difficult to 
say at what period $\mathrm{Xs}$ became ks. But the fact that it is written hs in OHG. and MHG. and chs in NHG. indicates that the change from the spirant to the explosive did not take place so early as in the other Germanic languages. Examples are : achse (OHG. ahsa, MHG. ahse), achsel (OHG. ahsala, MHG. ahsel), dachs (OHG. and MHG. dahs), and similarly in flachs, fuchs, lachs, ochse, sechs, wachs, wachsen, wechsel, \&c.

$\mathrm{x}$ disappeared before $\mathbf{s}+$ consonant in prehistoric $\mathrm{HG}$., as OHG. füst, NHG. faust, from *fuyxstiz (\$ 204); HG. mist $=$ Goth. maíhstus ; OHG. zëswa = Goth. taíhswō, right hand; OHG. wahst, wahsmo, beside wast (Goth. wahstus), wasmo, growth, were new formations after the analogy of wahsan; similarly OHG. sëhsto for *sësto, sixth after the analogy of sëhs.

\$283. The medial spirant disappeared after liquids in early NHG. It disappeared in Middle German during the twelfth century and then later in Upper German. Examples are: befehlen (MHG. befëlhen), föhre (MHG. vorhe), forelle (MHG. vorhele), mähre (MHG. merhe), möhre (MHG. mörhe), scheel (MHG. schëlch, gen. schëlhes), schielen (MHG. schilhen), welsch (MHG. welhisch).

\$ 284. When final, the spirant $x$ (written $\mathbf{h}$ in early $\mathrm{OHG}$. and $\mathrm{ch}$ in late $\mathrm{OHG}$. and $\mathrm{MHG}$.) remained in OHG. and MHG., and thus fell together with the ch from Germanic $\mathbf{k}(\S 288)$. In MHG. intervocalic $\mathbf{h}(\S 226)$ interchanged with final $\mathrm{ch}$, as sëhen, pret. sach; gen. schuohes, vlōhes, hōhes, beside nom. schuoch, vlōch, hōch. In NHG. the words which formerly had inflected forms with $\mathbf{h}$ beside uninflected forms with $\mathrm{ch}$ generally have the $\mathbf{h}$ finally by levelling out the inflected stem forms. Examples are pret. befahl (MHG. bevalch), sah (MHG. sach), schuh (MHG. schuoch), floh (MHG. vlöch), and similarly in nah, reh, rauh, but rauch-werk (MHG. rūch. 
wërc). We still have hoch beside höher, schmach beside schmähen, furche (MHG. vurch, pl. viurhe). Whereas the ch has remained in words which have no inflected forms, as doch, durch, nach, noch, \&c.

\section{$\mathbf{k}$}

$\S 285$. We have already seen ( $\$ 217)$ that Germanic k underwent a twofold development in OHG. according to its position in the word. Initially, medially and finally after consonants $(1, n, r)$, and when doubled, it remained except in High Alemanic where it became the affricata $\mathbf{k}_{\mathbf{X}}$ (written ch, cch). The further development of High Alemanic $\mathrm{kx}_{\mathrm{X}}$ does not concern the history of literary NHG. and is therefore omitted. Medially and finally after vowels single $\mathbf{k}$ was shifted to the double spirant $\mathrm{xx}$ (written $\mathbf{h h}, \mathrm{ch}, \mathbf{h}$ ) in all the OHG. dialects.

\$ 286. In OHG. $\mathbf{k}$ was generally written $\mathbf{c}$ except before $\mathbf{e}, \mathbf{i}$, where it was always written $\mathbf{k}$. In MHG. it was generally written $\mathbf{k}$ at the beginning and $\mathbf{c}$ at the end of a syllable, as korn; dankes, senken, beside danc, pret. sancte. Double kk was generally written ck (often also cc) in OHG. In MHG. and NHG. it is written ck. In OHG. and MHG. the ck was simplified to c, when final (\$ 223), but in NHG. it is always written ck.

OHG. $\mathbf{k}$ has generally remained in all periods of the language, as OHG. cunig, kalb, korn, kuo, klëbēn, kleini, knëtan, knio, krāen, kruog, quëllan = NHG. könig, kalb, korn, kuh, kleben, klein, kneten, knie, krähen, krug, quellen.

OHG. mëlkan, scalc, denken, sinkan, trinkan, starc, wërc, wirken $=$ NHG. melken, schalk, denken, sinken, trinken, stark, werk, wirken.

Examples of general Germanic and West Germanic kk (\$§ 202, 213-4) in HG. are: OHG. boc, lëccōn, loc, lockōn, stoc ; ackar, blicken, decken, drucken, wecken 
= NHG. bock, lecken, locke, locken, stock ; acker, blicken, decken, drücken, wecken.

\$287. Germanic sk became sx (written sc, sk, rarely sg) in late OHG. sx then became sch (= English sh) in the twelfth century. It is generally written sch in MHG. (often also sh in manuscripts), but the spelling sc, sk existed beside it down to the sixteenth century. Examples are : OHG. skadōn, scamēn, skeidan, skepfen, scōni, skioban, scrïban, sculdig = NHG. schaden, schämen, scheiden, schöpfen, schön, schieben, schreiben, schuldig. OHG. skal, skolan became sol (sal), solan = NHG. soll, sollen, in the eleventh century, cp. Northern Middle English sal for schal. OHG. aska, drëskan, misken, waskan, wunsken $=$ NHG. asche, dreschen, mischen, waschen, wünschen. OHG. diutisk, fisc, fleisk, irdisc, mennisco $=$ NHG. deutsch, fisch, fleisch, irdisch, mensch.

$\S 288$. The primitive HG. double spirant $x x$ was written hh in the oldest period of the language, but in the ninth century it began to be written ch and in the tenth century the ch became general, and has remained down to the present day, except that it is no longer a double consonant. The double spirant hh was simplified to $\mathbf{h}$ finally ( $\$ 223$ ); it was written ch in late OHG. and early $\mathrm{MHG}$. as in NHG. In the final position it thus fell together with OHG. ch from prim. Germanic final $x=$ Indg. $k$ ( $\$ 284)$. Examples are : early OHG. brëhhan, mahhōn, suohhen = MHG. brëchen, machen, suochen, NHG. brechen, machen, suchen; and similarly in NHG. gebrauchen, reich (OHG. rihhi), sprechen, stechen, wachen, woche, weichen, zeichen, \&c. It has become $\mathbf{g}$ in NHG. prägen (MHG. præchen, beside bræchen, OHG. brāhhen). NHG. geruhen (M HG. geruochen) is a new formation from ruhe.

OHG. blëh, būh, buoh, ih, gilīh, miluh, ouh, rouh, solih, storah, welih, pret. brah, sprah, stah = NHG. blech, bauch, buch, ich, gleich, milch, auch, rauch, solch, 
\$289-90] The High German Consonants 145

storch, welch, brach, sprach, stach. ch has disappeared in allmählich (older NHG. allmächlich, MHG. almechlich).

§289. NHG. sarg (OHG. saruh, MHG. sarch) and werg (OHG. wërah, MHG. wërch) are new formations made on analogy with words like berg (pronounced berch), $\operatorname{tag}(=$ tach $)$. sarch and werch first became written sarg and werg, and then the $\mathrm{g}$ was taken over into the inflected stem forms and pronounced like the $\mathbf{g}$ in berges, tages, \&c. In the same manner some words containing the suffixes .ich, -lich, now have .ig, -lig; as essig (MHG. ezzich), fittich (MHG. vittich), rettich (MHG. retich), beside fittig, rettg; ad(e)lig (Luther adelich), billig (Luther billich), ek(e)lig, häk(e)lig, völlig, untadelig, unzählig.

g

\$290. The chief points concerning the history of Germanic 3 , gg have already been given in $\S 218$. For the history of Germanic $\mathrm{gg}$ in HG. see $\$ 250$. Further examples of single $\mathrm{g}$ in OHG. and NHG. are: OHG. gast, gëban, glas, glat, got, graban, gras, guot $=$ NHG. gast, geben, glas, glatt, gott, graben, gras, gut.

OHG. biogan, fliogan, fogal, frāgēn, gidigan, gizogan, hagal, klagōn, nagal, neigen, sagēn, swìgēn, tragan, zeigōn = NHG. biegen, fliegen, vogel, fragen, gediegen, gezogen, hagel, klagen, nagel, neigen, sagen, schweigen, tragen, zeigen.

OHG. bërgan, bisorgēn, firlougnen, folgēn, morgan = NHG. bergen, besorgen, verläugnen, folgen, morgen. OHG. menigi, NHG. menge ( $(250)$.

In MHG. the medial combinations igi, ege (äge) were contracted to $\overline{1}$, ei. Several of the contracted forms have survived in NHG., as beichte (MHG. bihte, older bigihte), eidechse (MHG. egedëhsa), elster (MHG. eilster, older ägelster), getreide (MHG. getregede), maid (MHG. gen. dat. sing. meide, older mägede), nelke ( $M$ HG. neilkin, 
older negelkin), verteidngen (late MHG. verteidingen, older vertägedingen).

$\S 291$. West Germanic $\boldsymbol{z}^{j}$ became gg in Franconian and kk (also written cc, ck) in Upper German (\$ 218), as OHG. mugga, mucca, MHG. mügge, mücke, midge. NHG. has ck in all such words, as brücke, ecke, hecke, liucke, mücke, rïcken, weck. flügge is due to Low German influence. Words like dogge, flagge, roggen (early NHG. rocken) are of Low German origin. Here the gg does not go back to $3 \mathbf{j}$.

$\$$ 292. Examples of final $\mathrm{g}$ are: OHG. lag, mag, tag; einag, ēwīg, ginādìg, heilag, honag, sālìg, sculdīg = NHG. lag, mag, tag ; einig, ewig, gnädig, heilig, honig, selig, schuldig. OHG. and NHG. balg, arg, berg, burg, \&c.

NHG. mark, gen. markes (MHG. marc, gen. marges), has levelled out the uninflected form. In NHG. manch, older NHG. manech (OHG. manag, manig), beside mannigfach, -faltig, the ig (pronounced .ich) became written (i)ch, (e)ch, and was then extended to the inflected forms. Cp. the opposite kind of levelling in \$284.

\section{The Sibilant s.}

\$293. Germanic $s$ was in OHG. a voiceless spirant in all positions like the $\mathbf{s}$ in English sit. On the history of Germanic sk in HG. see $\$ 287$.

In MHG. $\mathbf{s}$ became a lenis medially between vowels and probably also initially before vowels. In NHG. it became a voiced spirant initially before vowels and medially between voiced sounds at the same time the lenes $b, d, g$ became voiced explosives ( $\$ \mathbf{2 2 6}$ ). In these positions the s became voiced at an early period in Low German.

Examples are: sagen, segen, sehen, singen, sohn; amsel (OHG. amsala), besen, lesen, linse, lösen, riese, \&c. Beside erbosen (MHG. erbosen), there formerly existed erbossen 
on the false assumption that the word originally contained 3 (cp. § 263).

$\$ 294$. In the fourteenth and fifteenth centuries $s$ became sh medially after $\mathbf{r}$ and initially before $\mathbf{p}, \mathbf{t}$ (written $\mathbf{s}$ ), $1, \mathbf{m}, \mathbf{n}, \mathbf{w}$ (written $\mathbf{s c h}$ ). Traces of this sound-change occur so early as the end of the thirteenth century, as barsch (MHG. bars), birschen (MHG. birsen), and similarly in bursche, dorsche, herrschen, kirsche, knirschen, \&c. Through the influence of the orthography, the s sound has been restored before a following $\mathbf{t}$, as borste, biorste, durst, garstig, gerste, horst, karst, wurst. All these words were formerly pronounced with sch just as they still are in many NHG. dialects. The s sound has also been restored in börse (the same word as bursche), ferse, hirse.

OHG. slāfan, smëlzan, snëcke, sprëhhan, stein, swëster = NHG. schlafen, schmelzen, schnecke, sprechen, stein, schwester; and similarly in schlingen, schmerz, schnell, schneiden, spielen, springen, stehlen, sterben, stechen, schwarz, schweigen, \&c.

\$295. It has remained voiceless in all periods of the language, when doubled; when preceded or followed by a voiceless consonant; and when final, as kiissen (OHG. kussen), presse, missen; angst (OHG. angust), gast, fuchs, wachsen; gans, gras, hals, haus, ich las, maus, \&c. When final s came to stand between voiced sounds it became voiced, as gänse, häuser, \&c.

\$296. s has become sch in gischt, older NHG. gäscht (MHG. gëst, jëst), gischen, older NHG. gäschen (MHG. gëschen, jësen), groschen (MHG. grosse, gros), harnisch (MHG. harnesch, beside harnas). $\mathrm{s}$ has disappeared by assimilation in sechzehn (OHG. sëhszëhan), sechzig (OHG. sëhszug). 


\section{CHAPTER XIII \\ WORD-FORMATION}

$\S 297$. By far the greater part of the word-forming elements, used in the parent language, were no longer felt as such in the oldest period of the German language, and still less in MHG. and NHG. In this chapter we shall chiefly confine ourselves to those elements which play an important part in the modern language, such as prefixes and suffixes.

\section{Nouns.}

$\S 298$. Nouns may be divided into simple, derivative, and compound. Examples of simple nouns are:-aal, baum, buch, burg, dachs, dorf, eiche, fell, fisch, fuchs, fuss, gras, hahn, haus, hund, joch, kalb, kind, korn, lamm, land, lohn, luft, meer, nacht, name, ochs, ohr, see, sitte, sohn, tag, volk, wahl, weg, weib, wolf, zeit. Many simple nouns are related to the various classes of strong verbs ( $\$$ 490-519), as steig, streit; griff, kniff, riss, ritt, schlich, schmiss, schnitt, trieb.

fliege; bote, flug, fluss, lüge, nutz, schub, schuss, stoss, trug, her-zog, zug.

binde, hilfe, spinne; band, drang, schwang, trank, zwang ; bund, fund, hülfe, schwund, sprung, trunk, wourf.

breche, scheere, stich; dieb-stahl; sprache; bruch, spruch. sitz; gabe, mass.

grab, schlag, stand; fuhre, grube, wuchs. fall, fang, gang, hang, lauf, rat, ruf, schlaf.

$\$ 299$. Derivative nouns are formed in a great variety of ways :-

I. From adjectives, as breite, dicke, fulle, güte, hitze, höhe, kälte, länge, menge, nähe, richte, röte, schärfe, schnelle, schwäche, schwere, stärke, tiefe, weite. See § $\mathbf{3 7 2 .}$ 
2. By means of various suffixes which are no longer felt as such, as achsel, ärmel, hagel, handel, nagel, sessel, vogel, zügel; regen, segen, wagen ; donner, futter, lager; wasser, winter; bruder, mutter, schwester, tochter, vater. On the ending of the infinitive of verbs, see $\S \mathbf{4 8 6}$.

3. From verbs by means of a dental suffix, as andacht, ankunft, bucht, fahrt, flucht, geburt, kluft, kunst, last, macht, pflicht, saat, schlacht, schrift, tat, tracht, trift, zucht.

4. From verbs with inseparable particles, as bedarf, befehl, beginn, begriff, behelf, beleg, bescheid, beschlag, besitz, bestand, besuch, beweis, bezug; empfang, entgelt ; erlass, ertrag, erwerb; gebiss, gebrauch, gefecht, geflecht, gehalt, gemuss, geruch, gesang, geschrei, gesicht, gewalt, gewinn; verband, verbleib, verbot, verdruss, verkauf, verlust, vermögen, versand, vertrag, verweis.

5. By means of various prefixes: aber- (the same as NHG. aber), as aberglaube, abername, abersaat, aberwandel, aberwitz. after- (the same as English after), as afterblatt, afterkiel, afterkind, afterkritik, afterlehre, aftermiete, aftermuse, afterpacht, afterrede. ant. (OHG. ant., see ent$\S 333$ ), as antlitz, antwort. bei- (same as the preposition bei, OHG. bī), as beifall, beilage, beispiel, beistand, beitrag. erz-(OHG. erzi-, MHG. erze-, Gr. ápxเ-, Engl. arch.), as erzamt, erzbischof, erzdieb, erzdummkopf, erzfeind, erzherzog, erzkämmerer, erzschelm. für-(OHG. furi, see ver- § 337), as fürbitte, fürsorge. ge. (OHG. gi-, used in forming collective nouns, see $\S 363$ ), as gebirge, gebüsch, gedränge, gefäss, gefilde, geflügel, gehölz, gelächter, gelände, geläut, gemisch, gepäck, gepräge, geriist, geschirr, geschwister, gespräch, gestein, gewässer, gewürm. miss- (OHG. missi-, MHG. misse-), as missbehagen, missbrauch, missernte, missetat, missgunst, missklang, misslaut, misswachs. un. (same as Eng. un.), as unart, unehre, unfall, unfug, unglïck, unkosten, unmasse, unrecht, unruhe, unschuld, untat, unzahl. ur. (OHG. ur, Goth. us, out, see er. $\S 334$ ), as urahn, 
urbild, urfreude, urkraft, urlaub, ursache, urschrift, ursprung, urteil, urvater, urzeit.

\section{Noun Suffixes.}

$\$ 300$. $\cdot$ chen (Middle Low German $\cdot k i n=k+$ in where each element is a dim. suffix, MHG. (Middle German dialect) -chin, -chen), as bisschen, kästchen, mädchen, männchen, söhnchen, vögelchen. -chen is not used when the simplex ends in a guttural spirant, as bächlein, not *bäch. chen. Forms like büchelchen, mädelchen, wägelchen have double dim. suffixes.

\$301. -ei (MHG. -ie, of Old French origin. It was originally confined to French loan-words and then spread to native words, especially to nomina agentis ending in -er, whence the new suffix, MHG. -erie, NHG. -erei which is often added to verbs. In like manner from forms like betteler, heucheler, the -elei has sometimes been extended to words which did not originally contain el, as liebelei), as abtei, partei, wiistenei; bäckerei, fischerei, jägerei; betrügerei, fahrerei, lauferei, ruferei, schreiberei, spielerei; gankelei, schmeichelei. In abgötterei, kinderei the ei has been added to the plural.

§ 302. -er (OHG. -ări, MHG. -ære, -er, Goth. -areis, $\mathrm{OE}$. -ere, Lat. -ārius, originally used to form nomina agentis from other nouns, and then later from verbs also, as OHG. fiscāri, fischer; rihtāri, richter), as eigentümer, fleischer, förster, handwerker, schäfer, schüler; bäcker, erzieher, finder, führer, haushalter, läufer, lehrer, leser, maler, nachfolger, nehmer, prediger, räuber, sänger, schneider, spinner, vorsteher, weber. After the analogy of the nomina agentis a large number of nomina instrumenti have been formed from verbs in NHG., as brenner (of a lamp), drücker (of a latch), eisbrecher, fernsprecher, klopfer, leuchter, schieber, iiberzicher, wecker, \&c.

The -er attached to the names of places and countries is 
of the same origin as the er in the nomina agentis, as Berliner, Kölner, Leipziger, Münchener, Schweizer. When used before other nouns, as Berliner tageblatt, Münchener bier, they are old gen. plurals used adjectively.

From nomina agentis, formed from nouns ending in •el, -en, have been extracted the NHG. suffixes -ler and -ner. Regular forms are : bettler (OHG. bëtalāri), fiedler, händler, sattler, stammler (OHG. stamalāri), vogler (OHG. foga1āri); gärtner (OHG. gartināri, beside gartāri), hafner (OHG. hafanāri), wagner (OHG. waganāri). Then after the analogy of such words, have been formed gegenfüssler, kïnstler, nachzügler, tischler, volksparteiler, zünftler; bildner (MHG. bildenære, beside bildære), flaschner, glöckner, kellner, kirchner, pförtner, redner, schuldner (already in OHG. sculdināri), söldner, \&c.

§ 303. -heit (OHG. and MHG. -heit, OE. -hād, NE. -hood. Also used as an independent noun : Goth. háidus, manner, way, OE. hād, OHG. heit, grade, rank, MHG. heit, kind, manner, quality), used to form abstract nouns from adjectives, past participles, and occasionally from nouns, as dreiheit, dummheit, ebenheit, einheit, flachheit, freiheit, gesundheit, grossheit, hoheit, krankheit, leerheit, schlauheit, schönheit, schwachheit, sicherheit, trockenhert, wahrheit, weisheit; berühmtheit, betroffenheit, ergebenheit, gebundenheit, gelehrtheit, gewandtheit, verlegenheit, verschzeiegenheit; christenheit, gottheit, kindheit.

From abstract nouns formed from adjectives ending in OHG. -ag, -.̌̆g, MHG. -ec, -ic (as OHG. heilagheit, MHG. heilecheit, heilekeit; OHG. sālīgheit, MHG. sælecheit, sælekeit), was extracted in MHG. the new suffix -keit, which is now used especially in forming nouns from adjec. tives ending in -bar, -er, -lich, -sam, and -ig, as brauchbar. keit, dankbarkeit, fruchtbarkeit, furchtbarkeit, lesbarkeit, trinkbarkeit; bitterkeit, heiterkeit, sauberkeit, tapferkeit; ängstlichkeit, ehrlichkeit, herzlichkeit, sterblichkeit, wunderlich. 
keit; arbeitsamkeit, aufmerksamkeit, biegsamkeit, duldsamkeit, grausamkeit, sparsamkeit; dürftigkeit, einigkeit, ewigkeit, fähigkeit, fertigkeit, mässigkeit, nachlässigkeit, seligkeit, uppigkeit.

From nouns formed from adjectives ending in -ig there has been extracted a new suffix -igkeit in NHG., which is now used in forming nouns from adjectives, especially those ending in -los, as achtlosigkeit, gottlosigkeit, lieblosigkeit, treulosigkeit, \&c.; dichtigkeit, feuchtigkeit, härtigkeit, kleinigkeit, neuigkeit, süssigkeit, zaghaftigkeit.

\$ 304. -icht (OHG. -ahi, MHG. -ehe, -ihe, also -ech, -ich with loss of final -e, NHG. -icht with excrescent -t), as binsicht, dickicht, dornicht, kehricht, röhricht, spülicht, tannicht.

§ 305. -in (OHG. -in, acc. -inna, MHG. -in, (-in), -inne, West Germanic innjō, used to form the feminine from nouns denoting male beings, see $\S 370$ ), as Berlinerin, Engländerin, erbin, feindin, freundin, fürstin, gattin, gefährtin, gemahlin, gräfin, heldin, herrin, herzogin, hündin, königin, löwin, näherin, sängerin, schwägerin, wirtin, wölfin.

§ 306. -ing (OHG. -ing, English -ing), as OHG. hāring, MHG. hærinc, hering; OHG. arming, poor man, formed from arm ; ediling, edeling, formed from edili, edel. From nouns like edeling there has been extracted the suffix -ling, which is very common especially in forming nouns denoting persons, as ankömmling, blendling, dümmling, feigling, flüchtling, fremdling, frömmling, gründling, häuptling, lehrling, liebling, neuling, säugling, sonderling, täufling, zögling ; däumling, frühling, säuerling, sprössling.

$\S$ 307. -lein (OHG., Franconian -ilinn, Upper German -ili. -ilin $=i 1+i n$ where each element is a dim. suffix. MHG. -ili beside -ilin, later -(e)lin. -li is still used in the Modern Upper German dialects to form diminutives), as fräulein, häuslein, kindlein, knäblein, lämmlein, mägdlein, schifflein, söhnlein, vöglein (older vögellein). 
§ 308. -nis (OHG. -nissi, MHG. -nisse, OE. -nes, NE. -ness), as ärgernis, bedrängnis, bedürfnis, begräbnis, bekenntnis, besorgnis, betrübnis, bewandtnis, bündnis, empfängnis, ereignis, erkenntnis, erlaubnis, ersparnis, erträgnis, finsternis, gedächtnis, gefängnis, geheimnis, gleichnis, hemmnis, hindernis, verderbnis, verhältnis, vermächtnis, versäumnis, verständnis, verzeichnis, wagnis, wildnis, zengnis.

\$ 309. -sal, -sel (OHG. -isal, MHG. -sel beside -sal with secondary accent), as drangsal, irrsal, labsal, mühsal, rinnsal, schicksal, trübsal, wirrsal ; anhängsel, füllsel, einschiebsel, geschreibsel, gemengsel, hecksel, rätsel, überbleibsel.

\$ 310. -schaft (OHG. -scaf, late OHG. -scaft, MHG. -schaft, related to Goth. ga-skapjan, to create, shape), as bekanntschaft, botschaft, brïderschaft, dienerschaft, eigenschaft, feindschaft, freundschaft, herrschaft, gemeinschaft, gesellschaft, kundschaft, landschaft, meisterschaft, nachbarschaft, verwandtschaft, wirtschaft, wissenschaft.

§ 311. tum (OHG. and $\mathrm{MHG}$. -tuom, OE. -dōm, NE. -dom, also used as an independent word, Goth. dōms, OE. dōm, judgment, OHG. tuom, state, condition), as altertum, besitztum, christentum, eigentum, heiligtum, herzogtum, irr. tum, kaisertum, königtum, mönchtum, priestertum, reichtum, rittertum, volkstum.

\$ 312. -ung (OHG. -unga, $\mathrm{MHG}$. -unge, used especially to form abstract nouns from verbs), as achtung, bekehrung, bemerkung, beschädigung, beschirmung, besinnung, besorgung, besserung, betrachtung, bildung, brandung, dämmerung, cinbildung, einleitung, festung, geltung, genesung, handlung, heilung, hoffnung, ladung, mündung, nahrung, regierung, reinigung, richtung, scheidung, sendung, sitzung, stallung, verfolgung, versammlung, verständigung, versuchung, vorstellung, wanderung, warnung, wirkung, zeichnung, zeitung. 


\section{Compound Nouns.}

§313. In compound nouns formed by composition the second element is always a noun, but the first element may be a noun, adjective, verb, or a particle. When the first element of the compound was a noun, it was not so often inflected in the older period of the language as it is now. Examples are: buchbinder, dienstmann, hauptmann, haushaltung, herberge (OHG. heri-bërga, lit. army shelter), jammerschade, milchmädchen, seemann, wasserträger, zahnschmerz; feinschmecker, grossvater, halbbruder, hochmut, hochschule, levchtsinn, mehrzal, wehmut; bindfaden, fuhrmann, giesskanne, raubvogel, schlafzimmer, schreibfeder, sterbe. zimmer, zugtier; wohltat; ablass, abteil, aufwand, einnahme, nebenzimmer, oberlippe, überzicher, umfang, untergang, unterrock, vorderarm, vorteil, vorwent.

$\S$ 314. After the analogy of compounds in which the first element is a masculine or neuter noun with the gen. singular ending in -(e)s, the $\mathbf{s}$ has been extended to a large number of compounds in which the first element is a feminine noun. Analogical formations of this kind do not occur in MHG., but from the sixteenth century onwards they became more and more common. Regular forms are: bundesrat, feuersnot, friedensbrecher, gerichtsamt, königssohn, lebensart, sonntagskleid, volksrecht, \&c. Then after the analogy of such nouns, there have been formed: auskunftsmittel, frauensperson, freiheitsliebe, geburtstag, heiratsgeschenk, hochzeitsfest, liebesbrief, mietsleute, regier. ungsrat, zeitungsjunge, \&c.

Other examples of compound nouns in which the first element is inflected are: augenlied, erdensohn, frauenfuss, fürstenschloss, gerstenmehl, hahnenfeder, knabenzeit, löwenfell, Märzenveilchen, mondenschein, riesengeduld, schwanenlied, sonnenschurm, tintenfass; eierhändler, gänsebraten, kindererziehung. 
\$ 315. The second element of compounds is sometimes an old dat. plural, especially in proper names, which is no longer felt as such, as Königshofen, Schaffhausen, Unter. walden; weihnachten.

\section{Adjectives.}

\$316. Adjectives, like nouns, may be conveniently divided into three classes: simple, derivative, and compound. Examples of simple adjectives are : alt, blind, drei, fest, frer, froh, grau, gut, hart, klug, kühl, lahm, lang, leer, lieb, nass, neu, rot, sanft, scharf, schwach, schwer, stark, tief, voll, wahr, warm, zahm, zehn.

\$317. Derivative adjectives often have the same inseparable prefixes as nouns $(\$ \mathbf{2 9 9}, 5)$, as erzdumm, erzfaul ; unfreundlich, unhöflich, unschön; uralt, urdeutsch; bedenklich, begreiflich, behülflich, bekanntlich, beliebig, bequem, betriebsam, beweglich ; erfindsam, erfreulich, ergiebig, erreichbar, erträglich; empfindlich, enthaltsam; gebührlich, gedeihlich, gefällig, geflügelt, gelaunt; verderblich, vergeblich, vernïnftig, verschämt; zerbrechlich.

\section{Adjectival Suffixes.}

§ 318. ·bar (OHG. •bāri, MHG. •bære, OE. •bǣre, in lēohtbǣre, bright, lit. light-bearing, Lat. .fer, in lūcifer, light-bringing; related to OHG. bëran, to bear), as ausführbar, bestreitbar, brauchbar, dankbar, denkbar, erreichbar, findbar, fühlbar, gangbar, haftbar, haltbar, hörbar, kostbar, lesbar, sichtbar, sonderbar, strafbar, streitbar, tragbar, trink. bar, vernehmbar; dienstbar, offenbar.

\$ 319. .en (OHG. -in, MHG. .en, Goth. -ein, OE. -en, prim. Germanic -inaz = Lat. .inus), as eichen, irden, seiden, \&c. Forms like golden (OHG. guldin, NHG. gülden), wollen (OHG. wullin) have been formed direct from gold and wolle in NHG.

From adjectives formed from noun-forms ending in er 
(mostly plurals in -er) there has been extracted the new suffix -ern. Regular forms are : gläsern, hölzern, hörnern; kupfern, ledern, silbern. After the analogy of such nouns have been formed: beinern, blechern, bleiern, flächsern, stählern, steinern, tönern, \&c.

§ 320. .haft (OHG. and MHG. .haft. Also used as an independent word, OHG. haft, vinctus, captivus ; a captive, OE. hæft, one seized or taken; a captive, cp. Goth. hafts, joined, Lat. captus, a taking, seizing, related to Goth. hafjan, OE. hebban, OHG. heffen, to heave, raise), as boshaft, dauerhaft, ernsthaft, fabelhaft, fehlerhaft, frevelhaft, gewissenhaft, lehrhaft, mangelhaft, meisterhaft, nahrhaft, schïlerhaft, tadelhaft, vorteilhaft, wohnhaft, wurzelhaft, zwei. felhaft. To some adjectives ending in -haft the suffix .ig has been added, as leibhaftig, standhaftig, teilhaftig, wahrhaftig.

§ 321. .icht (OHG. -aht, .oht, beside -ahti, -ohti (ja. stems), MHG. -eht (= NHG. .icht), beside -oht, OE. .iht as in stǣniht, stony), as holzicht, nebelicht, steinicht, töricht, \&c.

\$ 322. .ig (OHG. .ag, . . $\mathrm{ig}, \mathrm{MHG}$. -ec, .ic, Goth. -ag, ·eig, $\mathrm{OE}$. -ig, NE. -y), as abhängig, allmächtig, ausgiebig, beliebig, bissig, blutig, dortig, dürftig, einig, ergiebig, fähig, fertig, gebiurtig, gefällig, gläubig, gnädig, grimmig, gültig, gütig, häufig, kräftig, lebendig, lästig, lustig, mühselig, mutig, nachlässig, nötig, prächtig, richtig, schuldig, sonnig, streitig, sündig, trübselig, unartig, unzählig, vernünftig, völlig, weitläufig, wichtig, zeitig, zornig.

\$ 323. .isch (OHG. -isc, -isk, MHG. -isch, .esch, Goth. .isk, OE. .isc, NE. .ish), as ausländisch, dichterisch, deutsch (OHG. diutisc, popularis, formed from diot, people, cp. OE. pēodisc, popularis; language), as englisch, erfinderisch, hïbsch (MHG. hübesch; related to hof), irdisch, kindisch, malerisch, närrisch, räuberisch, regnerisch (with er from words like malerisch), schelmisch, städtisch, träumerisch, verschwenderisch. 
\$ 324. -lich (OHG. -lïch, M HG. -lïch, -lich, Goth. -leik, OE. -lic, NE. -ly. Also preserved as an independent word in Goth. ga-leiks, OHG. gi-lich, NHG. gleich, OE. gelic, NE. like), as bedenklich, begreiflich, behülflich, bekanntlich, beweglich, deutlich, dringlich, folglich, fraglich, freundlich, freundschaftlich, einheitlich, empfindlich, erfreulich, erklärlich, erträglich, gänzlich, gebiuhrlich, gedeihlich, gefährlich, gelegentlich, glaublich, glücklich, heimlich, hoffentlich, jährlich, jämmerlich, käuflich, kränklich, männlich, möglich, nachbarlich, reinlich, schädlich, schriftlich, schwerlich, stcrblich, täglich, trefflich, tunlich, ïblich, väterlich, vorderblich, ver. geblich, verständlich, verträglich, wahrlich, weiblich, weisslich, weltlich, wissenschaftlich, wörtlich, wunderlich, zärtlich, serbrechlich, ziemlich.

\$325. -los (OHG. and MHG. .1ōs, Goth. .láus, OE. -leas, NE. less. Also used as an independent word, Goth. láus, empty, OE. lēas, devoid of, OHG. 1ōs, NHG. los), as achtlos, arglos, chrlos, endlos, gottlos, grundlos, harmlos, herilos, hoffnungslos, kinderlos, leblos, selbstlos, tadellos, vaterlos, zahnlos.

\$ 326. -sam (OHG. and MHG. -sam, Goth. -sam (only in lustu-sams, longed for, much desired), OE. sum. Also used as an independent word, Goth. sama, same, OHG. sama, in like manner), as achtsam, arbeitsam, betriebsam, biegsam, einsam, enthaltsam, erfindsam, furchtsam, gehorsam, gemeinsam, genügsam, gleichsam, grausam, langsam, mühsam, ratsam, sorgsam, sparsam, strebsam, wirksam, wunder. sam. seltsam (OHG. sëltsāni, MHG. sëltsæne) has been remodelled upon the analogy of the adjectives in -sam.

\$327. Suffixes, which were no longer felt as such in OHG., are omitted, e.g. the •el, -en, and -er in adjectives like dunkel, edel, eitel; eigen, trocken; bitter, lauter, munter, tapfer. On the suffixes in the present and past participles see $\S$ 487-8. 


\section{Compound Adjectives.}

$\S 328$. In compound adjectives formed by composition the second element is always an adjective, but the first element may be a noun, adjective, verb, or a particle. Examples are: blitzschnell, blutarm, blutjung, einwandfrei, feindselig (formed after the analogy of leutselig), frucht. tragend, gesetzmässig, glückselig, grundschlecht, handbreit, hausbacken, jammervoll, leutselig, liebeleer, masshaltend, pflichtmässig, rauchfrei, regelmässig, steinalt, teilnehmend, todkrank, verhältnismässig ; geisteskrank, inhaltsreich, kriegsmässig, lesenswert, segensreich, sehenswirdig, staatskhig, vorwurfsvoll, volksmässig; gewohnheitsmässig, hoffnungsvoll, ordnungsgemäss, vorschriftsmässig, see § 314 ; augenfällig, jahrelang, kinderreich, riesengross, wochenlang; allgemein, blondhaarig, eigenartig, cinstimmig, freigebig, graugelb, grossartig, hellfarbig, hochwichtig, kaltblitig, kurzsichtig, langarmig, mehrdeutig, vielfach, vierfüssig, vierzehn, vollbliitig, zweispännig ; barmherzig, merkwürdig ; durchsichtig, nachlässig, überlang, ïbernächtig.

\section{VERBS.}

$\S 329$. From a morphological point of view, all verbs may be divided into two great classes : simple and compound. Simple verbs are subdivided into primary and denominative verbs. To the former subdivision belong the strong verbs and a certain number of weak verbs, and to the latter the denominative verbs. The simple primary verbs are here left out of further consideration, as their formation belongs to the wider field of comparative grammar. Compound verbs are of various kinds: (I) those formed from simple verbs by means of separable or in. separable particles, (2) those formed from nouns and adjectives with verbal prefixes or suffixes. Separable 
verbs call for no further comment, because they merely consist of the juxtaposition of two independent words.

$\S 330$. Simple verbs are formed direct from nouns and adjectives, as arbeiten (OHG. arbeitōn, formed from arbeit), and similarly ackern, bahnen, beten, bilden, blättern, duften, ebnen, erben, färben, fesseln, flüchten, füttern, hassen, köpfen, loben, meistern, nageln, nennen, regnen, satteln, tadeln; antworten, brandmarken, frohlocken, frühstücken, handhaben, heiraten, herbergen, kundschaften, langweilen, lustwandeln, mutmassen, ratschlagen, übernachten, urteilen, wetteifern, wirtschaften; fälschen, fillen, heilen, kühlen, kïrzen, lecren, lösen, nässen, öffnen, röten, schwächen, täuben, töten, trïben, zähmen; nötigen, rechtfertigen, \&c.

$\S 331$. Compound verbs formed from simple verbs, nouns, and adjectives. For the history of the development of meanings of the inseparable verbal prefixes, the student should consult a good German dictionary such as Paul's Deutsches Wörterbuch.

\$332. be (OHG. bi., the unstressed form of the pre. position $\mathrm{b} \mathbf{i}=$ NHG. bei), as befinden (OHG. bifindan), and similarly begiessen, begraben, begreifen, behalten, beschreiben, besitzen, bestehen, beziehen, bezwingen, bleiben (OHG. bili. ban, MHG. belíben, beside bliben. The vowel in be. began to disappear before 1 already in $\mathrm{MHG}_{\text {.) }}$; bedecken, bekennen, beweinen, bewohnen.

beantworten, befeinden, beflügeln, befreunden, begcistern, beglïcken, begrenzen, beherbergen, beobachten, beschatten, beschirmen, besegnen, besiegen, bestürmen, betonen, be. urlauben, bevölkern, beziffern.

be-engen, befeuchten, befreien, bereichern, bestärkcn; beendigen, be-erdigen, befähıgen, befestigen, befriedigen, beglaubigen, bekräftigen, bekreuzigen, belästigen, benachrichtigen, bereinigen, berichtigen, beruhigen, besänftigen, beschäftigen, beschönigen, beteiligen, bevollmächtigen.

§ 333. ent- (OHG. int., MHG. ent., the unstressed form 
of OHG. ant. (preserved in NHG. antlitz, antwort), Goth. and., Gr. ảvi', against, Lat. ante, before), as empfangen, cmpfehlen, empfinden (see \$ 247), entbieten, entbinden, entfallen, entflichen, entgehen, entgelten, enthalten, entlassen, entnehmen, entschliessen, entsprechen, entspringen, entstehen, entziehen; entblühen, entdecken, entfalten, enthüllen, entsagen, entstellen, enttäuschen.

entblättern, entehren, enterben, entfärben, entfesseln, ent. geistern, entkräften, entmannen, entnerven, entsiegeln, entvölkern, entwaffnen.

entfernen, entfremden, entheiligen, entledigen, entleeren, entmutigen, entschädigen, entschuldigen, entwürdigen.

Note.-In a few words NHG. ent. corresponds to OHG. in., Goth. in , the unstressed form of the preposition in, as entbrennen, entflammen, entschlafen, entschlummern, entzünden.

\$ 334. er. (OHG. ar., ir., MHG. er., the unstressed form of the preposition ur (preserved in NHG. urlaub, urteil), Goth. us, out), as erbrechen, erfechten, erfrieren, ergiessen, ergreifen, erklimmen, crleiden, erliegen, erlöschen, ermessen, erraten, ersaufen, erscheinen, erschlagen, erschleichen, er. schliessen, erschrecken, ersehen, ersinnen, ersitzen, erstehen, ersteigen, ersterben, ertragen, ertrinken, erwachsen, erwerben, erziehen; erbauen, erbeben, erblühen, erdenken, erdulden, erforschen, erfragen, erhoffen, erholen, erhören, erjagen, erleben, errichten, ersetzen, erstaunen, ersuchen, ertränken, erwarten, erwirken, erzeigen.

erarbeiten, eveilen, erglänzen, erhandeln, erkämpfen, crmorden, erteilen, erträumen, erzielen.

erbittern, erblinden, erfrischen, erfüllen, ergänzen, ergrauen, erheitern, erhöhen, erinnern, erkalten, erkälten, erklären, er. kranken, erlahmen, erledigen, ermatten, ermöglichen, ermüden, ermutigen, erneuen, eröffnen, erquicken, erröten, erschlaffen, erschweren, erstarken, erstarren, erïbrigen, erwarmen.

\$335. ge- (OHG. gi-, MHG. ge-, the unstressed form of 
$\left.\$ 33^{6-7}\right]$ Word-Formation

OHG. ga-, Goth. ga-. It is originally a preposition meaning 'together', which already in prim. Germanic was no longer used as an independent word): gebieten, gebären, gebrechen, gedeihen, gefallen, gefrieren, gelingen, genesen, geniessen, geraten, gerinnen, geschehen, gestehen, gewinnen; gebrauchen, gebühren, gedenken, gehorchen, gehören, geleiten, gereichen, gestatten, getrauen, gewähren, gewarten, gewöhnen, geziemen, glauben (OHG. gilouben. The vowel in gebegan to disappear before $\mathbf{1}, \mathbf{n}, \mathbf{r}$ already in $\mathrm{MHG}_{\text {., }}$ as glouben, gnāde, grade, beside gelouben, genāde, gerade).

Getrösten, gesegnen, gereuen, geloben, gelangen, \&c.

NotE.-On the ge- in past participles, see $\S 488$.

§ 336. miss-(OHG. missi-, M HG. misse-, Goth. missa-, English mis-, the same as the OHG. adjective missi, different) : missfallen, misslingen, missraten, missverstehen; missbehagen, missbrauchen, missdeuten, missgönnen, misskennen, missleiten, misstrauen.

missachten, missglücken, misshandeln, misstönen; miss. billigen.

\$337. ver- (oldest OHG. for-, fur-, later far-, fir-, late OHG. and MHG. ver-, Goth. faúr-, the unstressed form of OHG. furi (=NHG. für), fora, Goth. faúr, faúra, before. Already in the oldest OHG. three distinct, but etymologically connected particles, fell together, viz. three particles corresponding to Gothic faír-, faúr-, and frapreserved in NHG. fracht and fressen) : verbergen, verbinden, verbleiben, verderben, vergehen, vergessen, vergraben, verhehlen, verhelfen, verlassen, verlaufen, verleihen, vermeiden, vernehmen, verschieben, verschiessen, verschlafen, verschlingen, verschweigen, versehen, versinken, versitzen, versprechen, verstehen, vertreten, verwachsen; verbauen, verblühen, ver. brauchen, verbrennen, verdauen, verdienen, verfolgen, verjagen, verkleben, verlachen, verleiten, verreden, versenken, verstecken, versuchen, verwenden, verwirken, verzehren. 
verabschieden, verankern, veranstalten, verarbeiten, veraus. gaben, verbluten, verfeinden, vergolden, vergöttern, verhageln, verhungern, verklagen, verkleiden, vernageln, verschleiern, versiegeln, versilbern, versorgen, verspielen, versteinern, verursachen, verwerten, verzahnen, verzaubern, verzinsen.

verallgemeinern, veralten, verähnlichen, veranschaulichen, verarmen, verbessern, verbittern, verbreiten, verbreitern, verdächtigen, verdeutlichen, veredeln, vereinigen, vereiteln, verewigen, verfeinern, verfertigen, verfinstern, vergegenwärtigen, vergrössern, verheilen, verheimlichen, verherrlichen, verjüngern, verkleinern, verkündigen, vernachlässigen, veröden, veröffentlichen, verschönern, verständigen, verunreinigen, verwelken, verwirklichen.

§ 338. voll- (MHG. volle-, vol-, OHG. adverb follo, folle, completely, entirely, formed from the adj. fol, full): vollbringen (OHG. folle-bringan), vollziehen; vollenden, vollführen, vollstrecken.

§ 339. zer- (OHG. zar-, zir-, MHG. zer-, the unstressed form of OHG. zur- (in compound nouns), Goth. tus-, asunder, apart, and Gr. $\delta s^{-}$, hard, bad, ill, as in $\delta v \sigma-\mu a \theta \eta^{\prime}$, hard to learn, $\delta v \sigma-\mu \epsilon v \eta$ 's, ill-minded, hostile): zerbersten, zerbrechen, zerfallen, zerfliessen, zerfressen, zergehen, zerlassen, zerreiben, zerreissen, zerrinnen, zerschlagen, zerschmeissen, zerschneiden, zerspringen, zerstechen, zerstossen, zertreten, zerwerfen; zerhauen, zerkauen, zerklopfen, zerknicken, zerkratzen, zerlegen, zernagen, zerpflücken, zersetzen, zerspalten, zersprengen, zerstören, zerstreuen, zertrennen.

zerbröckeln, zerfleischen, zergliedern, zermalmen, zerpulvern, zerstückeln, zerteilen, zertrümmern.

\section{Verbal Suffixes.}

$\S$ 340. From verbs formed from noun and adjectival forms ending in -el and -er, the -el and -er have often been extended to other denominative verbs which did not originally have these suffixes. Many of the verbs belonging 
here have the force of frequentatives. Regular forms are : adeln, fesseln, flügeln, satteln, schnäbeln, stacheln, stammeln, tadeln, trommeln, veredeln, vermitteln, wechseln, wurzeln. After the analogy of such verbs have been formed: älteln, anheimeln, ausmergeln, betteln (also OHG. bëtalōn, formed from bëta, entreaty, request, and related to NHG. beten, bitten), fächeln, fälteln, frösteln, funkeln, häkeln, häufeln, hüsteln, kränkeln, kritzeln, künsteln, lächeln, liebäugeln, lispeln, näseln, rütteln, spötteln, streicheln, tänzeln, züngeln, \&c.

Regular forms are: ackern, buttern, feuern, futtern, füttern, hämmern, hungern, lästern, läutern, schimmern, schlummern, schneidern; from the plural of nouns : blättern, begeistern, bevölkern, erörtern, gliedern, rädern; from the comparative of adjectives: ärgern, bessern, erweitern, mindern, nähern, säubern, säuern, verschönern, vergewissern, vergrössern. After the analogy of such verbs have been formed : altern (older alten), blinkern, erschüttern, flimmern, folgern, glitzern, plätschern, räuchern, schlittern, schlüpfern, stottern, zögern, zwinkern, \&c.

$\S 341$. -ieren. The suffix -ier-was originally confined to verbs borrowed from Old French in the MHG. period (OFr. -ier, Mod. Fr. -er). At a later period it was extended to many other foreign words, as regieren, spazieren, studieren, \&c.; and still later, especially in the seventeenth and eighteenth centuries, to a large number of native words, as buchstabieren, gastieren, glasieren, halbieren, hausieren, hofieren, schattieren, stolzieren, verschimpfieren, \&c.

§ 342. -igen (OHG. -agōn, -ĭgōn, MHG. -egen). Verbs of this type were originally formed from adjectives ending in .ag, -.ّig, as OHG. heilagōn, MHG. heilegen, heiligen ; sculdigoon, MHG. schuldegen, (be)schuldigen. After the analogy of such verbs a large number of verbs containing this suffix were formed in MHG., and the number has been considerably increased in NHG. Regular forms are : bändigen, begünstigen, begütigen, bekräftigen, belästigen, 
bemächtigen, ermutigen, nötigen, reinigen, schädigen, \&c. Examples of analogical formationare : be-erdigen, befehligen, befestigen, beglaubigen, benachrichtigen, besänftigen, beschäftigen, bescheinigen, beschönigen, beseitigen, beschwichtigen, bewerkstelligen, endigen, genehmigen, huldigen, peinigen, sättigen, vereidigen, \&c.

§ 343. -zen (OHG. -azzen, -azen, later -ezen, $\mathrm{MHG}$. -zen; Goth. -atjan, OE. -ettan, used to form intensitive verbs). Examples are: ächzen, duzen, grunzen, jauchzen, krächzen, lechzen, schluchzen, schmatzen, schnalzen, \&c. In a few words the $\mathrm{z}$ has become $\mathrm{s}$ or $\mathbf{s c h}$, as drücksen, hopsen, klecksen, mucksen, plumpsen; mantschen, quietschen, rutschen. NHG. seufzen (MHG. siuften beside siufzen) has been remodelled on the analogy of the verbs in -zen. 


\section{A C C I D E N C E}

\section{CHAPTER XIV}

\section{NOUNS.}

\$ 344. In OHG. as in the oldest periods of the other Germanic languages, nouns are divided into two great classes, according as the stem originally ended in a vowel or a consonant, cp. the similar division of nouns in Sanskrit, Latin, and Greek. Nouns whose stems originally ended in a vowel belong to the vocalic or so-called strong declension. Those whose stems originally ended in $\cdot \mathbf{n}$ belong to the weak declension. All other consonantal stems will be put together under the general heading, 'Minor Declensions.'

Owing to the loss of final short vowels, and consonants in prehistoric HG. (\$\$ 161-2), several different kinds of stems regularly fell together in the nom. and acc. singular, so that from the point of view of OHG., the nom. and acc. singular end in consonants, and we are only able to classify such stems either by starting out from primitive Germanic, or from the plural, or from a comparison with the other old Germanic languages; thus the OHG. nom. and acc. singular of tag, wort, gast, hant, lamb correspond to prim. Germanic *đazaz, *đazan, older .os, .om ; *wurđan, older .om ; "zastiz, *zastin, older -is, .im ; *xanđuz (Goth. handus), *xanđun (Goth. handu); *lambaz, older -os (cp. Lat. genus, gen. generis). The original distinction between the nom. and acc. of masculine and feminine nouns had disappeared in the oldest period of 
the German language except in the $\mathbf{n} \cdot$; and the fem. jo-stems. In like manner the original case endings of the n-stems, with the exception of the nom. singular and gen. plural, had also disappeared in the oldest German, so that the element which originally formed part of the stem came to be regarded as a case ending ( $\$$ 161-2), cp. the similar process in the plural of the neuter os- stems. In order to understand the historical development of the declension of German nouns, it will be necessary for the student to master the chapter on vowels of unaccented syllables, the paragraphs dealing with the medial and final positions of the consonants in MHG. ( $\$ 226)$, and likewise the paragraphs concerning the lengthening of short vowels which were in open syllables in MHG. (\$\$ 105-113). Where in MHG. there was an interchange between medial lenis and final fortis, NHG. has usually generalized the medial form of the consonant ; and where in MHG. the stem vowel was now in a closed and now in an open syllable (as nom. hof, gen. hoves) NHG. has usually generalized the vowel of the open syllable.

\$345. OHG. nouns have two numbers: singular and plural ; three genders: masculine, feminine, and neuter, as in OE. from which the gender of nouns in OHG. does not materially differ ; five cases, Nominative, Accusative, Genitive, Dative, and Instrumental. The instrumental only occurs in the a., and masc. i-stems. The vocative is like the nominative. Traces of an old locative occur in what is called the uninflected dat. singular of hüs, house, and dorf, village ( $\$ 393)$.

$\S$ 346. Many nouns have changed gender in passing from $\mathrm{MHG}$. to NHG. In some nouns the change in gender began already in $\mathrm{MHG}$., owing to the weakening of the OHG. endings to e, whereby the nom. singular of many nouns of different genders fell together, as OHG. hirti (masc.), betti (neut.), gëba (fem.), namo (masc.), 
zunga (fem.), hërza (neut.) = MHG. hirte, bette, gëbe, name, zunge, hërze. In some nouns the change of gender was caused by the cases of the plural of different stems falling together in NHG., e.g. the plural of the MHG. neut. nouns molken, wāfen, wolken, \&c. fell together with the fem. plural of n-stems, then the former came to be regarded as fem. plurals, from which a new fem. singular has been formed, as NHG. molke, waffe, wolke, \&c.

Examples of nouns, which have changed their gender, are : NHG. masc. but MHG. fem. : frevel, horst, scheitel, verlust, witz; NHG. masc. but MHG. masc. and fem.: floh, rahmen; NHG. masc. but MHG. neut. : ablass, gau, honig, speer; NHG. masc. but MHG. masc. and neut.: abgott, jammer, lohn, mord, trank, zauber, zwerg; NHG. masc. but MHG. masc., fem., and neut. : schoss (lap).

NHG. fem. but MHG. masc. : albe, binse, esche, fahne, gräte, grille, heuschrecke, hirse, hornisse, imme, kohle, locke, metze, niere, schläfe, schlange, schnecke, schnepfe, scholle, spule, strähle, träne, wade, waise, woge, zähre; angel, angst, art, drangsal, otter, sitte; NHG. fem. but M HG. masc. and fem.: ameise, blume, dille, kresse, ratte, rebe, rose, saite, sonne, traube; bank, distel, furt, gewalt, heirat, list, luft, lust; NHG. fem. but MHG. masc. and neut. : matratze, spur; NHG. fem. but MHG. neut. : ähre, armbrust, grütze, kitze, marke, molke, unbilde, waffe, wange, wolke, zicke; milz, spreu; NHG. fem. but MHG. neut. and fem. : armut, beere, ecke, rippe, wette; heimat, jagd, mahd; abstract nouns in -ung(e), as manunge (NHG. mahnung), and in -nisse, as erkantnisse (NHG. erkenntnis), fluctuated between the fem. and neut. in MHG.

NHG. neut. but MHG. masc.: schrot, segel, zeng; NHG. neut. but MHG. neut. and masc. : lob; NHG. neut. but MHG. fem.: abenteuer, gewissen, gift, mass; NHG. neut. but MHG. fem. and neut. : gefängnis, panier, revier. 
A. The Vocalic or Strong Declension.

\section{The a-DECLENSION.}

$\S$ 347. The a.declension comprises masculine and neuter nouns only, and corresponds to the Latin and Greek o.declension (Gr. masc. -os, neut. -ov, Lat. -us, -um), for which reason it is sometimes called the o-declension. The a-declension is divided into pure a.stems, ja-stems, and wa.stems.

§ 348.

a. Pure a-stems.

Masculine.

\section{Sing. OHG.}

Nom. Acc. tag

Gen. tages

Dat. tage

Instr. tagu, $(\cdot 0)$
MHG.

tac

tages

tage
NHG.

tag

$\operatorname{tag}(\mathrm{e}) \mathrm{s}$

$\operatorname{tag}(e)$
Plur.

Nom. Acc. taga

Gen. tago

Dat. tagum, (.om) tage

tage

tagen tage

tage

tagen

The prim. Germanic forms were: sing. nom. *đazaz, acc. *đazan, gen. *đazesa (with pronominal ending, §450), dat. *đazai, instr. *đazō ; plur. nom. *đazōz (cp. Goth. dagōs), acc. *đazanz (cp. Goth. dagans), gen. *đazōn (cp. Gr. $\theta \epsilon \omega \hat{\omega}$, of gods), dat. * đazomiz. Through the loss of the endings the nom. and acc. sing. regularly fell together in OHG. In OHG. the original nom. pl. is also used for the accusative. The instr. singular disappeared in the tenth century; it has been preserved in the NHG. isolated form heute from *hiu tagu, on this day. The $\cdot \mathrm{m}$ in the dat. plural ending regularly became $\cdot \mathbf{n}$ in the ninth century, as also in all the other declensions. Nouns ending in the derivative suffixes -el, en, .er dropped the inflexional e in the singular and plural already in MHG. (\$171). On 
the loss of the e in the NHG. gen. and dat. singular see $\$ \S 177-8$.

$\S$ 349. Most of the nouns, which originally belonged to this class, have passed over into other declensions in the plural. Like tag are declined : arm, bord, buckel, druck (pl. drucke and driicke with differentiated meanings), gurt, hag, halm, hund, krach, mast, onkel, pardel, pfad, pudel, ruf, schacht, schuh, thron, and a few others. aal, lachs, luchs, and pfuhl belonged in MHG. to the i-declension ( $\$ 373$ ), pl. MHG. æle, lehse, lühse, pfuiele. Examples of nouns with palatal stem vowels are: berg, dieb, esel, finger, fisch, himmel, ring, sinn, stein, weg, \&c.

$\S 350$. Most of the nouns which originally belonged to this class have passed over into the i-declension in the plural. The masc, a. and i-stems were declined alike in the singular already in the prehistoric period of the language. And after the OHG. plural endings of the two classes had been weakened to ee, en in MHG. the only distinction between them was the presence or absence of umlaut in the plural. The a-stems began to be inflected like $\mathrm{i}$-stems in the plural already in MHG. in order to distinguish the two numbers. NHG. examples are : acker, arzt, baum, faden, frosch, fuchs, gang, hafen, hals, hammel, hammer, hof (cp. the old dat. pl. in proper names, as Königshofen), koch, lohn, mantel, ofen, sattel, schnabel, stuhl, traum, vogel, wagen (pl. wägen beside wagen), wolf, \&c.

$\S 351$. A small number of nouns form their plural after the analogy of the -os.stems (\$398). Some of these are due to the fact that their genders fluctuated in OHG. and MHG. Such masculine plurals rarely occurred in MHG., but they became more frequent in the fourteenth and fifteenth centuries. NHG. examples are : abgott (OHG. masc. and neut.), geist (with pl. after the analogy of gespenster), gott, leib, vormund (an old n-stem), wald (an old u.stem, cp. old dat. pl. in Unterwalden), wurm (an old 
i-stem), mann (an old consonant stem), dorn (an old u-stem; pl. dörner beside dorne, dornen), ort (pl. orte, older NHG. örte beside örter); nouns ending in ttum (OHG. masc. and neut.), whence NHG. irrtum, reichtum, beside neut. herzogtum, königtum, \&c.

\$352. bolzen (MHG. bolz) became weak and then levelled out the $\cdot \mathbf{n}$ into the nominative, from which a new genitive in -s has been formed, and similarly leisten (MHG. leist), nacken (MHG. nac), nutzen (cp. the old form in eigennutz, zu nutz und frommen); the new weak nom. has been preserved in gedanke (MHG. gedanc), haufe (MHG. houf) beside haufen. See $\$ 384$.

$\S 353$. held (MHG. helt, gen. heldes) has become weak in the oblique cases, and similarly christ (MHG. kristen, gen. kristenes). MHG. heiden, raben, gen. heidenes, rabenes, came to be regarded as weak in the plural, from which a new weak singular heide, rabe has been formed.

$\S 354$. felsen (MHG. velse) with $\mathbf{n}$ from the oblique cases, beside fels (MHG. vels) with weak forms from MHG. velse; bauer (MHG. gebūr beside gebūre), whence the NHG. strong and weak forms in the singular, but weak in the plural, and similarly nachbar (MHG. nāchgebūr). See $\$ 382$.

§355. muskel, pantoffel, staat, stachel, stiefel (pl. also stiefel), untertan, and zins have become weak in the plural.

$\S 356$. Neuter.

Sing.

Nom.Acc. wort

Gen. wortes

Dat. worte

MHG.

wort

wortes

Instr. wortu, (.o)

worte

Plur.

Nom. Acc. wort

wort

Gen. worto

worte

Dat. wortum, (-om) worten

NHG.

wort

wort(e)s

wort(e) 
In OHG. the neuter a-stems had the same endings as the masculine except in the nom. and acc. plural. The prim. Germanic form of the nom. and acc. plural was *worđō. The final $\cdot \overline{0}$ became $\cdot \mathbf{u}$ and then regularly disappeared after long stem syllables ( $\$ 162)$. Plurals with short stem syllables, like *fazz u, vats, ${ }^{*}$ jochu, yokes, dropped the $\cdot \mathbf{u}$ after the analogy of wort, pfund, bein, \&c. In Middle German the plural began to take $e$ in the nom. and acc. after the analogy of the masculines in the MHG. period. NHG. examples are : brot, haar, jahr (the old instr. sing. has been preserved in heuer, OHG. hiuru from *hiu jāru), joch, los, moos, paar, pfund, rohr, ross, schaf; bein, ding (pl. also dinger), fell, gebet, recht, schiff, seil, spiel, tier, werk, \&c. Cp. § 173.

Nouns ending in .el, en, -er and the diminutives in .chen (MHG. - kinn), -lein (MHG. -lin), have not added -e in the plural in NHG., as feuer (MHG. viur), messer, mittel, muster, segel, wesen; mädchen, veilchen, kindlein, vög(e)lein, \&c.

The old uninflected form of the neuter plural has been preserved in nouns preceded by a numeral, as drer glas, sechs pfund, \&c., and then after the analogy of these also with some masculine and feminine nouns, as drei fuss, tausend mann, sechs uhr, \&c.

\$ 357. A large number of nouns, which formerly belonged to this declension, have passed over into the -os-declension in the plural ( $\$ 398)$. This process began in OHG. and spread a little in MHG. In NHG. about a hundred nouns form their plural in er, such are : bad (cp. old dat. pl. in Baden), blatt, dach, fass, glas, grab, gras, haupt (NHG. dat. pl. zu häupten, after the analogy of zu füssen), horn, korn, kraut, loch, rad, schloss, tal, volk; brett, feld, geld, gesicht (old fem.), kind, kleid, licht, lied, nest, schwert, weib, \&c.

\$358. A few nouns, partly with differentiated meanings, 
still fluctuate in the plural, as bande, gewande, lande, worte, beside bänder, gewänder, länder, wörter.

\$350. Molke (MHG. molken), waffe, and wolke have become feminine with weak plurals. See § 346.

\$360. s-plurals. In Middle Low German s-plurals began to appear in the fifteenth century. The $\mathbf{s}$ was used in all cases of masculine and neuter nouns, and was due to the influence of Middle Dutch which had the ending from French. In High German it first occurred in names of persons and then became extended to a few other nouns, as die Webers, fräuleins, kerls, \&c.

$\S 381$.

b. ja.stems.

Masculine.

Sing. OHG.

Nom. Acc. hirti

Gen. hirtes

Dat. (hirtie), hirte

Instr. (hirtiu), hirtu, (-o)

Plur.

Nom. Acc. (hirte), hirta

Gen. (hirteo, io), hirto

Dat. hirtum, (.om; ·im)
MHG.

hirte

hirtes

hirte

hirte

hirte

hirten

The forms within brackets are the oldest ; from the ninth century onwards the declension of hirti only differed from that of tag in the nom. and acc. singular.

hirte began to be declined like a weak noun already in MHG. owing to the nom. singular of both declensions being alike, whence NHG. hirt(e), gen. hirten, \&c., and similarly MHG. rücke, weize which have levelled out the $\boldsymbol{n}$ of the oblique cases into the nominative and formed a new gen. in -s : rücken, weizen, gen. rückens, weizens. käse (OHG. kāsi, MHG. kæse) has remained strong.

\$362. To this declension also belong the nomina 
agentis, as lehrer (OHG. lērāri, MHG. lērære), fischer, jäger, wächter, \&c., which have regularly lost the final ee in the nom. and acc. singular $(\$ 174, I)$, and the inflexional e in the other cases $(\$ 175)$.

$\S 363$.

Neuter.

Sing. OHG.

Nom. Acc. nezzi

Gen. nezzes

Dat. (nezzie), nezze

Instr. (nezziu), nezzu, (.o)
MHG.

netze

netzes

netze

netze

netze

netzen
NHG. netz netzes netze

\section{Plur.}

Nom. Acc. nezzi

Gen. (nezzeo, -io), nezzo

Dat. nezzum, (-om; -im)

In OHG. the nouns of this declension only differed from the masculines in the nom. and acc. plural.

A large number of the nouns belonging to this declension have regularly lost the final $\cdot e$ in the nom. and acc. singular (\$174), as antlitz, gebiet, gedicht, gefäss, gemäss, geschäft, geschenk, gesetz, gestirn, gewächs, gewicht, heer (MHG. her, § 171), \&c., whereas others have regularly retained it $(\$ \mathbf{1 7 4}, \mathbf{2})$, as gebäude, gebirge, gebilde, gefilde, gelände, gemüse, gesinde, getreide, gewölbe, \&c.

In some nouns the final ee has been dropped in order to make a distinction between the singular and plural, as erz, heft, hirn, kinn, kreuz, netz, reich, stück, \&c.

\$ 364. bett (MHG. bette), ende, and hemd (MHG. and early NHG. hemde), have become weak in the plural. bild (MHG. bilde), gemüt (MHG. gemuiete), and geschlecht have passed over into the -er plurals (\$ 398). kleinod (MHG. kleinœte), the plural of which was formerly kleinot, kleinote, and kleinoter, now has the pl. klein. odien, due to association with the latinized sing. form kleinodium. 


\section{c. Wa.STEMS.}

\$ 365. In OHG. the endings were the same as those of the a-stems except in the nom. and acc. singular and the neut. nom. and acc. plural, which ended in -o. The final .w became vocalized to $\cdot 0$ in prehistoric HG. ( $\$ 236)$, and was then dropped after long vowels in the ninth century, as OHG. masc. nom. and accusative snēo (Goth. snáiws), later snē, gen. snēwes, dat. snēwe, MHG. snē, snēwes, snēwe; OHG. neut. nom. and accusative kneo, gen. knëwes, dat. knëwe, pl. kneo, gen. knëwo, dat. knëwum ; MHG. knie, gen. kniewes, \&c. In OHG. and MHG. the w was preserved in the oblique cases, but in NHG. the form of the nom. and acc. singular has been levelled out, as masc. bau, klee, schnee, see (originally a wi-stem, cp. OE. $\mathbf{s æ})$ was formerly masculine only. The NHG. distinction der see, the lake, and die see, the sea, is due to the influence of Low German. The plural has become weak. schatten (MHG. schate) became weak and then levelled out the $\cdot \mathbf{n}$ of the oblique cases into the nominative, from which a new gen. in $\cdot \mathbf{s}$ has been formed.

Examples of neuters are: mehl (MHG. mël, gen. mëlwes), schmer (MHG. smër, gen. smërwes), occasionally also masculine.

\section{The ō-DECLENSION.}

§ 366. The ō-declension contains feminine nouns only, and corresponds to the Latin and Greek $\overline{\mathbf{a}}$-declension, for which reason it is sometimes called the $\overline{\mathbf{a}}$-declension. In OHG. the wō.stems were declined exactly like the pure ö-stems. The jō-stems had also the same inflexions as the pure $\overline{0}$-stems after about the middle of the ninth century. 
§ 367.

a. Pure ō-stems.

Sing. OHG.

Nom. Acc. gëba

Gen. gëbā, $(\cdot \mathbf{u}, \cdot 0)$

Dat. gëbu, $(\cdot 0)$

Plur.

Nom. Acc. gëbā

Gen. gëbōno

Dat. gëbōm
MHG.

gëbe, zal

gëbe, zal

gëbe, zal

gëbe, zal

gëben, zaln

gëben, zaln
NHG.

gabe, zahl

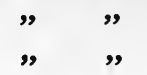

gaben, zahlen

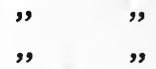

The prim. Germanic forms were: Sing. nom. *zeøo, acc. * zebōn (cp. Gr. $\left.\chi^{\omega} \omega \bar{\rho} \bar{\nu}\right)$ ), gen. * zeচ̄ōz (Goth. gibōs), dat. *zeচ̄o (old instrumental) ; Plur. nom. acc. * zeচ̄ōz (Goth. gibōs), gen. *zebōn (Goth. gibō), dat. *zebōmiz (Goth. gibōm). In OHG. the nom. acc. singular gëba is the old accusative. The regular ending of the nom. would be $\cdot u$ in nouns with a short stem syllable and loss of $\cdot u$ in nouns with a long stem $(\$ 162,2)$. The old nom. was preserved in words like OHG. kuningin ( $\$ 370$ ), and in a few words like stunt, time, hour; buoz, remedy, redress. The dat. came to be used for the gen. singular in late OHG. The gen. plural had the ending of the weak declension (\$ 387) already in the oldest period of the language. Through the nom. sing., gen. and dat. pl. having the same endings as the feminine weak declension, ō-stems began in OHG. to be inflected after the analogy of the weak declension, especially in the plural. This process spread considerably in MHG. with concrete nouns, but not often with abstract nouns. In NHG. nearly all nouns originally belonging to this declension have gone over into the weak declension in the plural, so as to keep up the distinction between the singular and plural; and vice versa the feminine weak nouns have become strong in the singular for the same reason. It is remarkable that whereas the feminine $\overline{\mathbf{o}}$. stems have chiefly gone over into the weak declension in 
the pluiral, the masculine a.stems have chiefly gone over into the i-declension in the plural, which hardly ever happened with the $\overline{0}$-stems. In fact many old feminine i.stems have also gone over into the weak declension in the plural ( $\$ 387)$. NHG. examples of old $\overline{0}$-stems are : asche, bitte, erde (weak sing. form in auf erden, erdensohn), ehre, frage, klage, sache, seele, sprache, stimme, strasse, stunde, \&c. NHG. elle (MHG. ellen, elne, OHG. elina) : in MHG. the sing. and plural fell together in ellen, from which in NHG. a new singular elle has been formed.

$\S 368$. In MHG. the final .e was regularly dropped after liquids preceded by a short vowel, as zal (OHG. zala), fackel (OHG. faccala), fëder (OHG. fëdera). See § 171. In NHG. the final ee has been dropped in a number of words, as acht (MHG. āhte), bahn (MHG. bane), and similarly in hut, held, kost, mark (boundary), pein, qual, scham, schau, schlacht, schuld, stirn, tracht ; and the abstract nouns ending in -ung (M HG. -unge), as hoffnung, mahnung; feier (MHG. vìre), leier (MHG. lìre), maner (MHG. mūre), steuer (M HG. stiure), trauer (M HG. trūre); on the ending .er, see $\$ 128$.

§ 369. ferse (OHG. fërsana, $M H G$. vërsen), kette $(\mathrm{OHG}$. ketina, MHG. keten(e)), kïche (OHG. kuchina, MHG. küchen). In these nouns the plural in MHG. fell together with the weak declension, to which a new singular without $\cdot \mathbf{n}$ has been formed in NHG.

\section{b. jō-stems.}

$\$$ 370. In the oldest period of the language the sing. nom., acc., and genitive ended in .e, and the dat. in .iu; pl. nom. and acc. ee, gen. eeōno, dat. •eōm; but from about the middle of the ninth century onwards, the nouns belonging to this class were inflected like gëba, except those formed with the West Germanic suffix innjo. which preserved the old form of the nominative without $\cdot u(\$ 162)$, 
$\S \S 37$ 1-2] Nouns

as nom. kuningin, acc. kuninginna. In late OHG. the old nom. was also used for the accusative, and vice versa, whence the double forms in MHG.

\section{Sing. OHG.}

Nom. kuningin

Acc. kuninginna

Gen. kuninginnā

Dat. kuninginnu, (.o)

\section{Plur.}

Nom.
Acc. kuninginnā

Gen. kuninginnōno

Dat. kuninginnōm
MHG.

NHG.

NHG. examples of nouns belonging to this class are: brücke, hölle, hütte, rede, sünde, \&c.; freundin, gattin, gemahlin, wirtin, \&c. See $\$ 305$.

\section{c. Wō.STEMS.}

\$ 371. The nouns belonging to this class were declined in OHG. like gëba. NHG. examples are : brane (OHG. brāwa), farbe (OHG. farawa), garbe in schafgarbe (OHG. garawa), reue (OHG. riuwa), treue (OHG. triuwa).

\section{Feminine Abstract Nouns in -ī.}

\$ 372. This declension comprises two classes of stems which were originally different, but which entirely fell together in their inflexion in OHG.-(I) adjectival abstract nouns the stems of which originally ended in -in, nom. $\cdot \overline{1}$; (2) verbal abstract nouns with stems ending in -ini; cp. on the one hand Gothic mikilei, greatness, formed from mikils, great, diupei, depth, from diups, deep, gen. mikileins, diupeins (weak declension), OHG. hōhī, height, 
from hōh, high, menigi, multitude, from manag, much; and, on the other hand, Gothic dáupeins, a dipping, formed from dáupjan, to dip, naseins, a rescuing, from nasjan, to rescue, gen. dáupeináis, naseináis (i-declension), OHG. toufi, a dipping, from toufen, to dip. In OHG. all cases of the singular ended in $\cdot \overline{1}$ or $\cdot \overline{i n}$; the endings of the plural were nom. and acc. $\cdot \overline{1}$ or $\cdot \bar{i}$, gen. -ino, dat. $\cdot i m$. The $\cdot \overline{1}$ was weakened to $\cdot e$ in $\mathrm{MHG}$., whence $\mathrm{NHG}$. höhe, menge, and, similarly, fülle, güte, länge, nähe, schärfe, stärke, tiefe; weite, \&c. ; taufe. The nouns of this class, which have a plural in NHG., form it weak.

\section{The i-Declension.}

§373.

Sing.

a. Masculine.

Nom. Acc. gast

Gen. gastes

OHG.

MHG.

NHG.

Dat. gaste gaste

gast gast

gastes gast(e)s

Instr. gastiu, gastu

gast(e)

PluR.

Nom. Acc. gesti

geste

Gen. gesteo, gesto

Dat. gestim

geste

gesten

gäste

gäste

gästen

The prim. Germanic forms were: sing. nom. *zastiz,

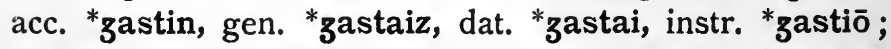
pl. nom. " ${ }^{*}$ astīz older .ijiz (Goth. gasteis), acc. *zastinz (Goth. gastins), gen. *zastiōn, dat. *zastimiz. The regular form of the gen. singular would be *gaste in OHG., gastes was formed on analogy with tages as in the other Germanic languages. The nouns with long stems fell together with the a-stems in the singular in prehistoric HG. The nom. acc. singular of the nouns with short stems would regularly end in. $\mathbf{i}$ in OHG., but, with two or 
three exceptions, they had dropped the $\cdot \mathbf{i}$ after the analogy of the long stems in the oldest period of the language. Owing to the singular of the a. and i-stems being alike, a.stems were occasionally inflected like $\mathrm{i}$-stems in OHG., and still more so in $\mathrm{MHG}$. In NHG. a great many old a.stems have passed over into this declension in the plural (\$350). A few nouns, which had umlaut in the plural in MHG., have gone over into the a-declension, as grat (MHG. pl. græte), lachs (MHG. pl. lehse), and similarly luchs, pfad. wurm (MHG. pl. würme) with er.plural in NHG. (\$ 398).

$\S$ 374. Nouns, which could not have umlaut in OHG. and MHG., fell together with the a-stems in the singular and plural, as MHG. brief, schrit, pl. briefe, schrite. Examples of old i-stems in NHG. are : apfel, ast, bach, balg, fall, fluss, nagel, schlag, \&c.

§375. b. Feminine.

Sing. OHG. MHG. NHG.

Nom. Acc. kraft

kraft

kraft

Gen. krefti

Dat. krefti

krefte, kraft

krefte, kraft

Plur.

Nom. Acc. krefti

krefte

Gen. krefteo, krefto krefte

kräfte

Dat. kreftim

kreften

kräfte

kräften

The masculine and feminine i-stems were originally declined alike in the singular and plural. The plurals

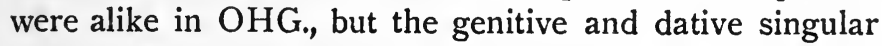
ended in $\cdot \mathbf{i}$. The OHG. dat. goes back to an original locative ending in -èi which was regularly shortened to $\cdot e i$ and became $\cdot \mathbf{i}$ in $\mathrm{OHG}$. through the intermediate stage $\cdot \bar{i}$. The dat. form then came to be used for the genitive already in the prehistoric period of the language, just as 
at a later period the dat. of the $\overline{0}$-stems came to be used for the genitive.

The short stems lost their final $\cdot i$ after the analogy of the long stems, except OHG. kuri, turi, MHG. kür(e), tür(e), NHG. kür, tür (türe, see below). In MHG. the nom. and acc. singular began to be used for the genitive and dative after the analogy of the $\overline{0}$-declension which had all cases of the singular alike (gëbe, zal). NHG. examples of old i-stems are: angst, axt, braut, frucht, macht (but ohnmachten, vollmachten), stadt, \&c.

\$376. The following nouns have become weak in the plural in NHG. : arbeit, anstalt, art, fahrt, flut, frist, furt, geburt, geiss, gestalt, gewalt, glut, jugend, last, list, pflicht, saat, schicht, schrift, schuld, tat, tugend, welt, zeit; and the derivative nouns ending in -heit (\$ 303), -keit (\$303), -schaft (\$310), as schönheit, freundlichkeit, botschaft, \&c.

$\S$ 377. In a certain number of nouns a new singular has been formed from the plural in NHG., and then the old plural has become weak, such are : beichte (MHG. bigiht, bīht, pl. bīhte), blüte (MHG. bluot, pl. blüete), ente (MHG. ant, pl. ente), and similarly erbse, furche, gemse, geschichte, hüfte, hürde, leiche, mähne, säule (MHG. sūl, pl. siule), stute, türe. In a few nouns we have the old and new singular forms side by side with differentiated meanings, as fahrt, stadt, beside fährte, stätte.

\section{The u.deClension.}

$\S$ 378. The u-declension was preserved in Gothic, but in OHG. it no longer existed as an independent declension. The nouns with long stems passed over into the a. or $i \cdot$ declension, chiefly the latter, in prehistoric times. Below will be found a summary of the more frequent traces of this declension in OHG. 


\section{a. Masculine.}

\$ 379. The short stems preserved the $\cdot \mathbf{u}$ in the nom. and acc. singular in OHG., as fridu, mëto older *mëtu, sigu, situ, sunu beside sun; in the other cases they had the endings of the $\mathbf{i}$-declension. The $\cdot \mathbf{u}$ became $\cdot 0$ in the ninth century ( $(168)$, which was regularly weakened to -e in MHG. ( $(170)$, as fride, mëte, sige, beside mët, sic, site, sun. fride and site were sometimes declined weak in MHG. MHG. fride, mët, sic (gen. siges), site, and sun regularly became friede, met, sieg, sitte, and sohn in NHG. friede (frieden) levelled out the $\cdot \mathbf{n}$ of the weak forms into the nominative, from which a new gen. in $\cdot \mathbf{s}$ has been formed. sitte has become feminine with weak plural, and sohn has gone over into the i-declension.

Examples of old long u-stems, which had gone over into the a. or i.declension in the oldest HG., are: dorn (Goth. paúrnus), tōd, death (Goth. dáupus), wald (Goth. *walpus); skilt, shield (Goth. skildus), widar, NHG. widder (Goth. wiprus), wirt (Goth. waírdus, host), and the abstract nouns in theit (Goth. háidus, manner). See §303.

\section{b. Neuter.}

\$380. OHG. fihu, NHG. vich (Goth. faíhu) retained the $\mathbf{u} \mathbf{u}$ in the nom. acc. singular, in the gen. and dat. singular it had the same endings as wort (\$ 356).

\section{c. Feminine.}

§ 381. In OHG. hant (Goth. handus) was declined like kraft ( $\$ 375)$, except that in the dat. plural it retained the old u-ending, hantum, also MHG. dat. plural handen beside henden, and gen. pl. hande (in the combinations aller hande, maneger hande) beside hende. The MHG. dat. singular has been preserved in NHG. behende, the gen. pl. in allerhand, and the dat. plural in abhanden, beihanden, vorhanden, zuhanden. Other old u-stems, 
which went over into the i-declension in OHG., are : fluot, NHG. flut (Goth. flōdus), lust (Goth. lustus, masc.).

\section{B. The Weak Declension (N-Stems).}

$\$ 382$.

a. Masculine.

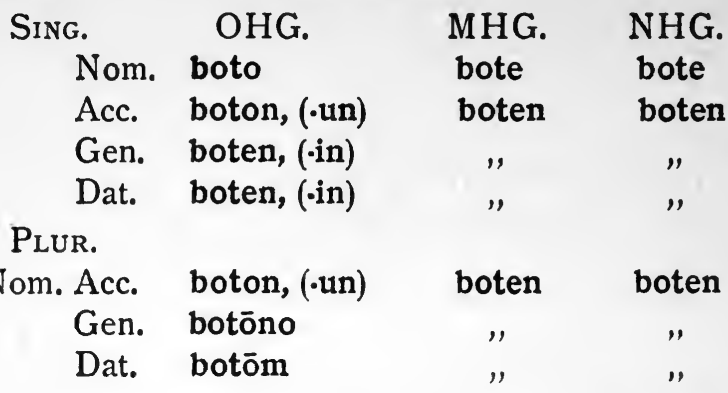

The prim. Germanic forms were : Sing. nom. * bođõ, acc. *bođonun, gen. *bođinaz, (.iz), dat. *bođini (old locative); plur. nom. *bođoniz, acc. *bođonunz, gen. *Dođnōn (West Germanic "bođōnōn with .ōnōn from the fem. nouns), dat. *bođōmiz. The 0 in the stem goes back to an older $\mathbf{u}(\$ 57)$ which ought to appear in the gen. and dat. singular, but the o was levelled out into all cases. In OHG. the nom. plural was used for the accusative.

The OHG. endings in, un were chiefly Upper German, and en, -on Franconian. Through the weakening of the endings in MHG. all the cases became alike except the nom. singular; this caused some nouns to begin to fluctuate between the strong and weak declension already in $\mathrm{MHG}$. In this declension it is important to distinguish between nouns denoting animate and those denoting inanimate objects. Nouns denoting animate objects are often used in the nominative as well as in the oblique cases, and have therefore generally preserved in NHG. the old distinction between the nominative and oblique cases and have 
remained weak; whereas nouns denoting inanimate objects are seldom used in the nominative, and have mostly levelled out the $\cdot \mathbf{n}$ of the oblique cases into the nominative, to which a new genitive in $\cdot \mathbf{s}$ has been formed.

Examples of nouns, which have preserved the final $\cdot e$ in the nominative and have remained weak, are: affe, ahne, bracke, bube, bürge, drache, erbe, falke, farre, ferge, fink(e), gatte, gefährte, geselle, hase, hüne, jude, kämpe, knabe, knappe, laffe, lave, löwe, neffe, ochs(e), pathe (pate), pfaffe, rabe (§ 353), rappe, recke, riese, scherge, schulze, schurke, sklave, zeuge, \&c.

A few nouns have lost the $\cdot e$ in the nom. singular, but have remained weak in the other cases of the singular and plural, as bär (acc. and dat. sing. also occasionally bär), fiurst, graf, herr, narr, prinz, tor, nerv. The following fluctuate between the weak and strong declension in the singular, but are weak in the plural : baner, nachbar, pfan, spatz, untertan. See $\S \mathbf{3 5 4}$.

$\S$ 383. Examples of nouns, which have levelled out the - $n$ of the oblique cases into the nominative, and to which a new genitive in $\cdot \mathbf{s}$ has been formed, are: backen, balken, ballen, barren, bissen, bogen, bolzen, braten, brocken, brunnen, daumen, flecken, fohlen, galgen, garten, graben, haken, hopfen, husten, kasten, kloben, knochen, knollen, knoten, koben, kolben, kragen, kuchen, laden, lappen, magen, nachen, pfosten, rachen, rahmen, rasen, riemen, roggen, schatten (\$ 365), schemen, scherben, schinken, schragen, schlitten, schnupfen, sporn (pl. sporne), stecken, tropfen, zapfen. This levelling took place almost exclusively with nouns denoting inanimate objects. Forms like nom. backen, gen. backens, began to appear about the end of the fifteenth century. The ending ens does not appear in weak nouns in MHG.

Of the above nouns, garten and graben have gone over into the $\mathbf{i}$-declension in the plural. bogen, kasten, kragen, and magen fluctuate between the $\mathbf{a}$. and $\mathbf{i}$-declension in the 
plural. laden has plural laden beside läden with differentiated meanings. The other nouns follow the a-declension in the plural.

\$ 384. In a few nouns the levelling out of the $\mathbf{n}$ of the oblique cases into the nominative has not been completely carried out. The following have the old beside the new nominative singular: friede beside frieden (old u-stem), funke beside funken, and similarly gedanke (\$ 352), glaube, haufe (\$ 352), name, same, wille, and schade with plural schaden beside schäden; buchstabe.

§385. gevatter, psalm, schmerz, and vetter have become strong in the singular, but have remained weak in the plural.

$\S$ 386. The following nouns have become strong, and gone over into the a-declension: aar, adler, ampfer, April, besen, blitz, bräutıgam (MHG. briutegome), brei, dotter, gemahl, hafer, hamster, junker (MHG. junc hërre), käfer, kern, leichnam, lenz, Mai, März (but Märzenveilchen), mond (but mondenlang), nabel, salm, schelm, schiefer, stern, stör.

hahn (but hahnenfeder, hahnenschrei), herzog, schwan (but schwanensang), tropf (dunce), have become strong, and gone over into the i-declension in the plural; anwalt has pl. anwalte beside anwälte.

$\S 387$.

b. Feminine.

$\begin{array}{cccc}\text { Sing. } & \text { OHG. } & \text { MHG. } & \text { NHG. } \\ \text { Nom. zunga } & \text { zunge } & \text { zunge } \\ \text { Acc. } & \text { zungūn } & \text { zungen } & " \\ \text { Gen. zungūn } & " & " \\ \text { Dat. zungūn } & " & "\end{array}$

Plur.

Nom. Acc. zungūn

zungen

zungen

Gen. zungōno

Dat. zungōm

, ,


On the $\cdot \overline{\mathrm{u}}$. in the OHG. gen. and dat. singular and nom. plural see $\$ 163$, note 2. Already in OHG. a few nouns fluctuated in the singular between the $\overline{0}$. and weak declension, and the number of such nouns increased in MHG. In NHG. the singular has become strong after the analogy of the ö-declension, so as to keep a clear distinction between the singular and plural. NHG. examples are: ameise, amme, blume, eule, gasse, geige, glocke, harfe, hose, katze, kerze, kirche, mücke, scheibe, sonne (but sonnenschem), taube, witwe, woche. biene (MHG. bie), and birne (MHG. bir) have $\mathbf{n}$ from the inflected forms. frau (but die kirche unserer lieben frauen = jungfrau Maria) had frou (used before proper names) beside frouwe in MHG.

§ 388.

c. Neuter.

Sing.

Nom. Acc. hërza

Gen. hërzen, (-in)

Dat. hërzen, (-in)

Plur.

Nom. Acc. hërzun, (.on)

Gen. hërzōno

Dat. hërzōm
MHG.

hërze

hërzen

hërzen

hërzen

" $"$,

Only four nouns belonged to this class in OHG.: hërza, ora, ouga, wanga. In NHG. herz (formerly also herze) has added the $\cdot s$ of the strong declension in the gen. singular. auge and ohr have become strong in the singular. wange has become feminine and is declined like zunge. 


\section{Minor Declensions.}

I. Monosyllabic Consonant Stems.

\section{a. Masculine.}

\$389. Of the nouns, which originally belonged to this class, only a few traces of the old inflexions are found in the earliest period of the language. fuoz, foot, and zan (zand), tooth, passed over into the i-declension, but the former preserved the old consonantal ending •um, (.om) in the dat. plural. In MHG. the dat. plural also went over into the i-declension (fuiezen); whence NHG. fuss, zahn, plural füsse, zähne. Traces of the old consonantal declension also exist in the uninflected dat. singular and nom. acc. plural of OHG. ginōz, and similarly in MHG. In other respects it was declined like tag. In NHG. genosse has become weak after the analogy of geselle.

$\S 390$.

Sing.

OHG.

MHG.

NHG.

Nom. man

Acc. man, mannan

Gen. man, mannes

Dat. man, manne

Plur.

Nom.

Acc. man

Gen. manno

Dat. mannum man

man

man, mannes mann(e)s

man, manne mann(e)

man, manne männer, mannen

man, manne

man, mannen mann

mann

mann(e)

The OHG. acc. singular mannan has the pronominal ending -an from proper names like nom. Petrus, acc. Petrusan, and such words as acc. truhtinan, Lord, gotan, God. The OHG. and MHG. gen. and dat. mannes, manne, and the MHG. nom. acc. plural manne were formed after the analogy of the a-declension. The NHG. 
weak plural mannen (vassals) began to appear in the eighteenth century; the plural männer has been formed after the analogy of weiber, kinder. The old plural has been preserved in combination with numerals, as tausend mann, but see $\S 356$.

\section{b. Feminine.}

\$391. Most of the nouns originally belonging to this class went over into the $\mathbf{i} \cdot$ declension in the oldest period of the language, as gans (MHG. gen. sing. still preserved in gänsebraten), kuh (OHG. kuo, pl. kuoi, MHG. kuo, pl. küeje), laus, magd (OHG. magad), milch, maus, nuss, sau (OHG. sū, pl. sūi, MHG. sū, pl. siuwe, NHG. pl. säue beside weak form sauen); eiche (MHG. eich, pl. eiche) has been formed from the NHG. plural which has become weak:

$\S 392$.

Sing.

OHG.

Nom. Acc. naht

Gen. naht

Dat. naht

Plur.

Nom. Acc. naht

Gen. nahto

Dat. nahtum

$\begin{array}{lc}\quad \text { MHG. } & \text { NHG. } \\ \text { naht } & \text { nacht } \\ \text { naht, nehte } & " \\ \text { naht, nehte } & "\end{array}$

naht, nehte naht, nehte nahten, nehten nächten

In MHG. the forms with umlaut are after the analogy of the feminine i.declension, whence the NHG. plural forms. The OHG. and MHG. isolated gen. form nahtes, dës nahtes was formed after the analogy of dës tages. The old dat. plural has been preserved in Weihnachten (MHG. zen wihen nahten). In OHG. and MHG. brust and burg were sometimes declined like naht and sometimes according to the i.declension. burg is now weak in the plural (formerly pl. also bürge), and brust, pl. briiste, 
is strong. In OHG. buoh was mostly neuter in the singular and declined like wort; in the plural it was feminine and declined like naht. In MHG. it became neuter in the plural also (pl. buoch and biiecher), whence NHG. plural bücher.

\section{c. Neuter.}

$\S$ 393. The old consonant stems dorf and hūs went over into the os-declension ( $\$ 398$ ) already in OHG. (MHG. pl. dörfer, hiuser), whence the NHG. plural dörfer, häuser, but the old dat. plural has been preserved in proper names, as Holthausen, Schaffhausen.

\section{Stems in $\cdot r$.}

\$ 394. To this class belonged in OHG. : fater, bruoder, muoter, tohter, and swëster.

$\$ 395$.

Sing.

OHG.

MHG.

Nom. Acc. fater

Gen. fater, fateres

Dat. fater, fatere

\begin{tabular}{ll}
\multicolumn{1}{c}{ MHG. } & NHG. \\
vater & vater \\
vater, vaters & vaters \\
vater, vater(e) & vater
\end{tabular}

Plur.

Nom. Acc. fatera

Gen. fatero

Dat. faterum

väter

väter

vätern

fater went over into the a-declension in OHG., and in MHG. the plural went over into the $\mathrm{i}$-declension, whence the NHG. plural väter. In the North German colloquial language vater is often used without the def. article, like a proper name, with acc. vatern, and similarly muttern.

§ 396.

Sing. OHG.

Nom. Acc. muoter

Gen. Dat.
MHG. muoter
NHG. mutter 
Plur.

$\begin{array}{rlll}\text { Nom. Acc. } & \text { muoter } & \text { muieter } & \text { mütter } \\ \text { Gen. } & \text { muotero } & \text { müeter(e) } & \text { mütter } \\ \text { Dat. } & \text { muoterum } & \text { müetern } & \text { müttern }\end{array}$

In MHG. the plural went over into the i-declension, and similarly brüeder, töhter, whence NHG. brüder, töchter. Like muoter were declined in OHG. bruoder, tohter, and swëster. bruoder began to take an $\cdot \mathrm{s}$ in the gen. singular in MHG. In NHG. schwester has gone over into the weak declension in the plural. Forms like mutters grab, grossmutters haus have been formed after the analogy of vaters grab, \&c.

§ $397 . \quad 3$. Stems IN $\cdot$ nt.

Sing. OHG. MHG. NHG. Nom. Acc. friunt vriunt freund Gen. friuntes vriundes freund(e)s Dat. friunte vriunde freund(e)

Plur.

Nom. Acc. friunt, friunta vriunt, vriunde freunde Gen. friunto vriunde Dat. friuntum vriunden freunde freunden

friunt went over into the a-declension in OHG. A trace of the old consonantal form exists in the nom. acc. plural friunt, MHG. vriunt; similarly OHG. fiant, NHG. feind.

To this class belonged originally the present participles as well as the old present participles used as nouns, such as feind, freund. But the present participles had passed over into the ja-declension of adjectives $(\$ 400)$ in the oldest period of the language. 
§ 398. 4. Stems in - os, es.

Sing.

Nom. Acc. lamb

Gen. lambes

Dat. lambe

Plur.

Nom. Acc. lembir

Gen. lembiro

Dat. lembirum
MHG.

lamp

lambes

lambe

lember

lember(e)

lember(e)n
NHG.

lamm

$\operatorname{lamm}(\mathrm{e}) \mathbf{s}$

$\operatorname{lamm}(\mathrm{e})$

This class of nouns corresponds to the Greek neuters in

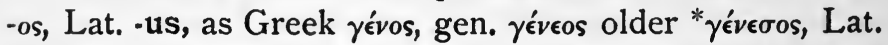
genus, gen. generis, pl. genera. In the oldest HG. the genitive and dative singular ended in -ires, -ire, but these endings disappeared at an early period, their place being taken by the endings of the a-declension. The -ir was originally a stem-forming suffix which came to be regarded as a plural ending. In the oldest period of the language only about half-a-dozen nouns belonged to this class, but during the OHG. period nearly twenty neuter a-stems passed into this declension, and in NHG. the number has increased to about a hundred. Examples are: blatt, ei, huhn, kalb, reis, rind; bad, buch, dach, dorf, haupt, haus, loch, tal, \&c. See $\$ 357$.

\section{CHAPTER XV ADJECTIVES}

A. The Declension of Adjectives.

$\$ 399$. In the parent Indg. language nouns and ad. jectives were declined alike without any distinction in endings, as in Latin, Greek, and Sanskrit. What is called the uninflected form of adjectives in the Germanic languages is a remnant of the time when nouns and adjectives were declined alike. But already in Indo- 
Germanic the pronominal adjectives had partly nominal and partly pronominal endings as in Sanskrit. In prim. Germanic the endings of the pronominal adjectives were extended to all adjectives. Then at a later period, but still in prehistoric HG., some of the case endings were influenced by those of the simple demonstrative pronoun $(\$ 449)$. These remarks apply to what is called in the Germanic languages the strong declension of adjectives.

The so-called weak declension of adjectives is a special Germanic formation by means of the suffixes en-, .on-, which were originally used to form nomina agentis, and attributive nouns, as Lat. edō (gen. edōnis), OHG. ëzzo (gen. ëzzen), glutton; Lat. adjectives catus, sly, cunning, rūfus, red, red-haired, silus, pug-nosed, beside the proper names Catō (gen. Catōnis), lit. the sly one, schlauberger, Rūfō, the red-haired man, Silō, the pug-nosed man; similarly in OHG. brūn, brown, kuoni, bold, beside the proper names Brūno, Kuono. In like manner Goth. blinds, OHG. blint, blind, beside Goth. blinda, OHG. blinto, which originally meant, the blind man; Goth. ahma sa weiha, lit. ghost the holy one. Such nouns came to be used attributively at an early period, and then later as adjectives. And already in prim. Germanic this weak declension became the rule when the adjective followed the definite article, as OHG. Ludowig thër snëllo, Ludwig the Brave, cp. NHG. Karl der Grosse, \&c. At a later period, but still in prim. Germanic, the two kinds of adjectives-strong and weak-became differentiated in use. When the one and when the other form is used in HG. is a question of syntax. There were adjectival $\mathbf{n}$-stems in the parent Indg. language, but they did not have vocalic stems beside them as is the case in the Germanic languages.

In $\mathrm{HG}$. the adjectives are declined as strong or weak. They have three genders, and the same cases as nouns. 


\section{The Strong Declension.}

$\$ 400$. The endings of the strong declension are partly nominal and partly pronominal, the latter are printed in italics for the OHG. forms. The nominal endings are those of the a. and $\overline{\mathbf{o}}$-declensions. The strong declension is divided into pure a., ō.stems, ja., jō-stems, and wa., wō-stems, like the corresponding nouns. The original i. and u-stems passed over into this declension in prehistoric HG. In OHG. the ja., jō- and the wa., wō-stems only differed from the pure a., ō.stems in the uninflected form. The uninflected form of the ja-stems ended in $\mathbf{i}$, which became ee in MHG., and has generally disappeared in NHG. The old ja-stems are still for the most part recognizable in NHG. by the umlaut in the stem, as OHG. dunni, engi, kūski, lāri, muodi, spāti, scōni, suozi, tiuri = MHG. dünne, enge, kiusche, lære, muiede, spæte, schœne, süeze, tiure = NHG. dünn, eng, keusch, leer, müde, spät, schön, süss, teuer. The uninflected form of the wa.stems ended in $\cdot 0$, which was dropped already in OHG. after long vowels and partly underwent contraction (§ 236), as blāo, blue, grāo, grey, later blā, grā ; frao (NHG. froh), rao (NHG. roh), later frō, rō; in other words, the $\cdot 0$ became $\cdot e$ in MHG. and was then dropped after 1 and $\mathbf{r}$, as OHG. falo, kalo, garo = MHG. val, kal, gar (\$ 171), NHG. fahl, kahl, gar.

The uninflected form of adjectives in the nom. sing. masc. and fem., and the nom. acc. neut. is a remnant of the time when adjectives had the same case endings as nouns, cp. nom. sing. OHG. tag, buoz, NHG. busse, nom. acc. sing. wort. In OHG. and MHG. the uninflected form could be used beside the inflected for the nom. sing. all genders and for the acc. neuter, whether the adjective was used attributively or predicatively, thus OHG. blint man, frouwa (woman), kind, beside blintēr man, blintiu 


\section{\$ 40I]}

frouwa, blintaz kind; alt was siu jāro, she was old in years. After the analogy of the predicate use of the uninflected form in the singular, it also came to be used predicatively in the plural in OHG., as die man sint blint or blinte, the men are blind; wir birun frō, we are joyful. In NHG. the uninflected form, for all numbers and genders, is only used predicatively.

On the inflexion of adjectives containing a suffixal el, em, en, er, see $\$ 175$.

\section{\$ 401.}

Sing.

OHG.

Masculine.

Nom. blint, blintēer blint, blinder blinder

Acc. blintan

Gen. blintes

Dat. blintemu, $(\cdot o)$ blindem(e)

Instr. blintu, $(\cdot 0)$

Plur.

Nom. Acc. blinte

Gen. blintero

blinden

blindes

Dat. blintēm, $(\cdot \bar{e} n)$

\section{MHG.}

NHG. blinde

blinder(e)

blinden blinde

blinder

blinden blinden

blinden, (-es)

blindem

\section{Feminine.}

Sing.

Nom. blint, blint $(i) u$ blint, blindiu blinde

Acc. blinta

Gen. blintera

Dat. blinteru, $(-o)$ blinde

blinder(e)

blinder(e) blinde

blinder

blinder

Plur.

Nom. Acc. blinto

Gen. blintero

Dat. blintēem, $(-\bar{e} n)$ blinde blinder(e)

blinden blinde blinder blinden 
Sing.

Nom. Acc. blint, blintaz blint, blindez blindes

Gen. blintes blindes

blinden, (-es)

Dat. blintemu, $(-o)$ blindem(e) blindem

Instr. blintu, $(\cdot 0)$

Plur.

Nom. Acc. blint $(i) u$

blindiu

Gen. blintero

Dat. blintēm, $(-\bar{e} n)$ blinder(e)

blinden blinde

blinder

blinden

§402. Singular: blintēr has $\overline{\mathrm{e}}$ from $h \overline{\mathrm{e}}(\$ \mathbf{4 3 8})+$ the nom. sign $r$ from older $z$. The acc. sing. blintan became blinten in the tenth century. The gen. sing. masc. and neut. began to have the weak ending en as early as the seventeenth century. The weak beside the strong form has been common since the middle of the eighteenth century. In present-day German the weak is the usual form. The instrumental case disappeared during the OHG. period. In Middle German the acc. fem. came to be used for the nom. in the MHG. period, whence the NHG. nom. and acc. blinde. The old nom. blindiu would have become *blindeu in NHG. The nom. acc. neut. blindaz became blindez in the tenth century. In the feminine the forms of the dat. and gen. began to be interchangeable in the ninth century; and from the tenth century onwards the dat. form was regularly used for both cases.

$\S$ 403. Plural : In Middle German the nom. acc. neut. came to have the masc. ending already in the $\mathrm{MHG}$, period, whence the NHG. form blinde. The gen. blintero became blintere in late OHG. The dat. ending eèm became een in the ninth century, and was shortened to en in late $\mathrm{OHG}$. 


\section{The Weak Declension.}

$\S$ 404. The weak declension of adjectives agrees with that of the weak nouns in all periods of the language except in the NHG. fem. singular. In NHG. the old nom. sing. fem. is used for the acc., but the gen. and dat. sing. have retained the weak endings, whereas in the nouns the old nom. sing. is used for all cases.

On the weakening of the OHG. case endings to $e$ in MHG., see $\$ 170$.

Masculine.

Sing. OHG. MHG.

Nom. blinto

Acc. blinton, (-un) blinden

Gen. Dat. blinten, (.in) blinden

Plur.

Nom. Acc. blinton, (-un) blinden

Gen. blintōno blinden

Dat. blintōm, (.ōn) blinden

\section{Feminine.}

SiNG.

Nom. blinta

Acc. blintūn

Gen. blintūn

Dat. blintūn

Plur.

Nom. Acc. blintūn

Gen. blintōno

blinde

blinden

blinden

blinden

Dat. blintōm, (.ōn) blinden

Neuter.

Sing.

Nom. Acc. blinta

Gen. Dat. blinten, (-in) blinde

blinden

blinden

blinden
NHG.

blinde

blinden

blinden

blinden blinden

blinden blinde

blinde

blinden

blinden

blinden

blinden

blinden

blinde

blinden 
Plur.

$\begin{array}{rlll}\text { Nom. Acc. } & \text { blintun, (-on) } & \text { blinden } & \text { blinden } \\ \text { Gen. } & \text { blintōno } & \text { blinden } & \text { blinden } \\ \text { Dat. } & \text { blintōm, (-ōn) } & \text { blinden } & \text { blinden }\end{array}$

B. The Comparison of Adjectives.

I. The Comparative Degree.

$\$ 405$. The Indg. parent language had several suffixes by means of which the comparative degree was formed. But in the individual branches of the parent language one of the suffixes generally became more productive than the rest, and in the course of time came to be the principal one from which the comparative was formed, the other suffixes only being preserved in isolated forms. The only Indg. comparative suffix, which remained productive in the Germanic languages, is -is - which became -iz- (= Goth. .iz., OHG. .ir.) in prim. Germanic by Verner's law. To this suffix was added in prim. Germanic, or probably in the pre-Germanic period, the formative suffix •en., -on-, as in Gr. $\dot{\eta} \delta \delta^{\prime} \omega \nu$ from ${ }^{*} \sigma F \bar{\alpha} \delta i \sigma \omega \nu$, gen. $\dot{\eta} \delta i^{\prime} o v o s,=$ Goth. sutiza, gen. sutizins, OHG. suoziro, sweeter, gen. suoziren, (-in). This explains why the comparative is declined weak in the oldest periods of the Germanic languages. Beside the suffix -iz. there was also in prim. Germanic a suffix $\cdot \overline{0} z$ (Goth. -ōz., OHG. -ōr.) which did not exist in IncloGermanic. This suffix is a special Germanic new formation, and arose from the comparative of adverbs whose positive originally ended in $\cdot \overline{0}$, Indg. .ỗd ( $\$$ 547). And then at a later period it became extended to adjectives.

In OHG. polysyllabic adjectives formed with derivative suffixes, and compound adjectives had the suffix -ōr-; ja-, jo.-stems the suffix .ir.; and uncompounded pure a., 
o-stems sometimes had the one, sometimes the other suffix, thus :-

Positive

sālīg, blessed

tiurlīb, dear

engi, narrow

suozi, sweet

lang, long

hōh, high
Comparative

sāligōro

tiurlīhhōro

engiro

suoziro

lengiro

(hōhiro

hōhōro

§ 408. .iro, -ōro became -ire, -ōre in late OHG., and in MHG. -ire, oore fell together in -er ( $\$ 171)$, so that in MHG., as in NHG., the presence or absence of umlaut in the stem is often the only indication as to which suffix was used in OHG. On MHG. and NHG. er beside •r, see $\S 175$.

In OHG. only stems originally containing a have umlaut, as Goth. alpiza, batiza, OHG. eltiro, older, bezziro, better. In MHG. most monosyllables have umlaut in the comparative either exclusively or have umlauted beside non-umlauted forms. The cause of these double forms is in a great measure due to the two OHG. suffixes -iro and -öro falling together in MHG. -er, as MHG. alter, armer, junger, grōzer, hōher, beside elter, ermer, jünger, grœzer, hœher, NHG. älter, ärmer, jünger, grösser, höher. In MHG. and NHG. those adjectives which have umlaut in the positive always retain it in the comparative, as MHG. duinne (OHG. dunni), thin, schœne (OHG. scōni), beautiful, spæte (OHG. spāti), late, suieze (OHG. suozi), sweet; comparative MHG. dünner, schœner, spæter, süezer, NHG. dünner, schöner, später, süsser. Quite a number of adjectives, especially monosyllabic, had umlaut in early NHG., which do not generally have it now, the number of non-umlauted forms having increased 
especially during the last seventy years. The following categories do not have umlaut in the comparative: (I) adjectives containing au in the stem, as faul, grau; (2) derivative adjectives ending in -bar, -el, -en, -er, -icht, -ig, -isch, -haft, -lich, -sam; (3) participial adjectives, as klagend, lobend; (4) foreign adjectives, as galant, kolossal, nobel; and about fifty monosyllabic adjectives: bar, barsch, blank, bunt, dumpf, falsch, flach, froh, hohl, hold, kahl, karg, knapp, lahm, lass, los, matt, morsch, nackt, platt, plump, rasch, roh, rund, sacht, sanft, satt, schlaff, schlank, schroff, starr, stolz, straff, stumm, stumpf, toll, voll, wahr, wund, zahm. In the following usage varies: bang, blass, brav, dumm, fromm, gesund, glatt, grob, nass, schmal, zart.

$\$ 407$. As we have seen above, the comparative was declined according to the weak declension in OHG., but already in late OHG. traces of the strong beside the weak declension began to appear, and in MHG. the strong and weak declension exist side by side just as in NHG. The chief factor in bringing about the strong declension of the comparative was the weakening of OHG. -iro, -oro to -er in MHG. It should be noted that the comparative is used both attributively and predicatively.

On the inflexion of comparatives whose positive ends in -el, $\cdot$ en, $\cdot$ er, see $\$ 175$.

\section{The Superlative Degree.}

$\$$ 408. The superlative, like the comparative degree, was formed in the Indg. parent language by means of several suffixes. But in the individual branches of the parent language one of the suffixes generally became more productive than the rest, and in the course of time came to be the principal one from which the superlative degree was formed, the other suffixes only being preserved in 
\$\$ 409-10] Adjectives

isolated forms. The only superlative suffix which remained productive in the Germanic languages is -to- in the combination isto., formed by adding the original superlative suffix -to. to the comparative suffix -is., as in

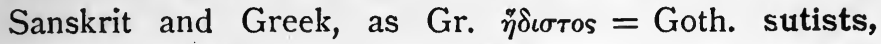
OHG. suozisto, sweetest. The simple superlative suffix .to- has been preserved in Gr., Lat., and the Germanic languages in the formation of the ordinal numerals, as Gr. ๕̈кros, Lat. sextus, Goth. saíhsta, OHG. sëhsto, sixth.

The Germanic suffix -ōst- was a new formation like -ōzin the comparative. In OHG. the adjectives which had -iro in the comparative had -isto in the superlative, and those which had ooro in the comparative had oosto in the superlative, thus sālīgōsto, tiurlīhhōsto, engisto, suozisto, lengisto, hōhisto, hōhōsto. See $\S 405$.

.isto, -ōsto became -iste, -ōste in late OHG., and fell together in MHG. est. What has been said under the comparative about umlaut, \&c., also applies to the superlative in OHG., MHG., and NHG. On MHG. and NHG. -est beside -st, see $\S 182$. MHG. altest, armest, jungest, grōzest, hōhest, beside eltest, ermest, jüngest, grœzest (grœst), hœhest, NHG. der älteste, ärmste, jüngste, grösste, höchste.

$\S 409$. In OHG. the superlative was declined according to the weak declension. Strong forms beside the weak began to appear in late OHG. In MHG. the strong and weak declension exist side by side just as in NHG. The superlative is only used attributively, and its uninflected form seldom occurs except when used adverbially.

\section{Irregular Comparison.}

$\S$ 410. The following adjectives form their comparatives and superlatives from a different root than the positive:- 
Goth. gōps

OHG. guot

MHG. guot

NHG. gut

OHG. luzzil, little MHG. lützel

NHG. wenig batiza bezziro

bezzer

besser

minniro

minner, (minre)

minder batists

bezzisto

bezzest, (beste)

best

minnisto

minnest, (minste)

mindest

The comp. and superl. with the meaning smaller, smallest were still used down to the eighteenth century. The meanings less, least have been evolved out of the new positive wenig and the MHG. adv. min (minner, minre), less, minnest (minste), least. mindest is a new formation from minder where $d$ was regular ( $\$ 273$ ).

Goth. mikils máiza

OHG. mihhil, great mēro

MHG. michel

NHG, viel mērer

mehr máists

meisto

meiste

meist

MHG. mērer is a double comparative, whence early NHG. mehrer, greater, as das mehrere teil (Luther), and this meaning was still preserved down to the eighteenth century. Late NHG. mehrere is plural. When the adj. michel was supplanted by viel, much, the old adjectival meanings of the comp. and superl. disappeared, and their place was taken by that of the old adv. MHG. mē(r), mēre, more, meist (meiste), most.

OHG. wirsiro, wirsisto, MHG. wirser, wirsest (wirste), used as the comp. and superl. of OHG. ubil, bad, MHG. übel, have disappeared in NHG.

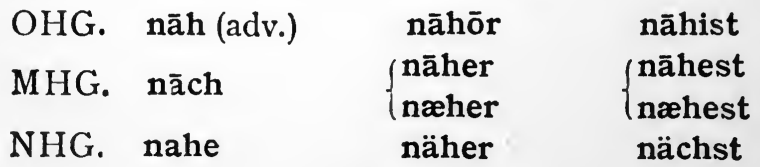


NHG. nah is the adj. corresponding to MHG. nāch, with $h$ from the inflected forms ( $\$$ 284), but NHG. nahe corresponds to the MHG. adv. nāhe, OHG. nāho.

\$ 411. Already in OHG. the superl. lezzisto (MHG. lezzeste, leste) was no longer felt as being the superl. of laz, idle. Late MHG. (Middle German dialect) letzte is from Low German lezt = letst, a shortened form of letist. The NHG. comp. letztere is a new formation from letzte.

$\S 412$. In a few cases the comparative and superlative were formed in OHG. from an adverb or preposition, as in Latin.

\begin{tabular}{|c|c|c|}
\hline $\begin{array}{l}\text { èr, formerly } \\
\text { fora, furi, before }\end{array}$ & $\begin{array}{l}\text { ēriro } \\
\text { furiro }\end{array}$ & $\begin{array}{l}\text { ēristo } \\
\text { furisto }\end{array}$ \\
\hline furdir, forwards & $\left\{\begin{array}{l}\text { fordro } \\
\text { fordaro, (-oro) }\end{array}\right\}$ & fordarōsto \\
\hline $\begin{array}{l}\text { hintar, behind } \\
\text { inne, within } \\
\text { oba, above } \\
\text { untar, down } \\
\text { ūz, ūzar, outside }\end{array}$ & $\begin{array}{l}\text { hintaro } \\
\text { innaro } \\
\text { obaro, (oboro) } \\
\text { untaro } \\
\text { ūzaro }\end{array}$ & $\begin{array}{l}\text { hintarōsto } \\
\text { innarōsto } \\
\text { obarōsto } \\
\text { untarōsto } \\
\text { ūzarōsto }\end{array}$ \\
\hline
\end{tabular}

Most of the above forms have survived in NHG. eristo (MHG. ērste, NHG. erste) was used as an ordinal number already in OHG. From NHG. erste has been formed the new comparative erstere. furisto was sometimes used in OHG. as an ordinal number beside èristo. It has been preserved in NHG. fürst. fordaro, fordarōsto correspond to NHG. vordere, vorderste; and similarly NHG. hintere, hinterste; innere, innerste; obere, oberste; untere, unterste. The old superl. obarōsto has also been preserved in NHG. obrist beside oberst, colonel. MHG. üzer, üzerst began to have umlaut after the analogy of other adjectives in late MHG., whence NHG. äussere, äusserste. The old comparative without umlaut still occurs in NHG. ausserhalb. 
C. Numerals.

§ 413.

I. Cardinal.

\section{OHG.}

ein

zwei

drī

feor, fior

fimf, finf

sëhs

sibun

ahto

niun

zëhan

einlif

zwelif

drizëhan

fiorzëhan

finfzëhan

sëh(s)zëhan

*sibunzëhan

ahtozëhan

niunzëhan

zweinzug

drīzzug, drīzug

fiorzug

finfzug

sëh(s)zug

sibunzug

ahtozug

niunzug

zëhanzug, hunt

zwei hunt

dūsunt

zwā dūsuntā
MHG.

ein

zwei

drī

vier

finf, fünf

sëhs

siben

ahte

niun

zëhen

einlif, eil(i)f

zwelf

drīzëhen

vierzëhen

finf., fünfzëhen

sëh(s)zëhen

sibenzëhen

ah(t)zëhen

niunzëhen

$z$ weinzic

drīzic

vierzic

finf., fünfzic

sëh(s)zic

sibenzic

$\operatorname{ah}(\mathrm{t}) z i c$

niunzic

zëhenzic, hundert

zwei hunt, hundert tūsent

zwei tūsent
NHG.

eins

zwei

drei

vier

fünf

sechs

sieben

acht

neun

zehn

elf

zwölf

dreizehn

vierzehn

fünfzehn

sechzehn

sieben., siebzehn

achtzehn

neunzehn

zwanzig

dreissig

vierzig

fünfzig

sechzig

sieben-, siebzig

achtzig

neunzig

hundert

$z$ wei hundert

tausend

zwei tausend 
NHG. eins is from the old inflected form of the neut., MHG. einez. zwei is the old neuter form, and drei the old masc. form. On OHG. fimf beside finf, see $\$ 246$. fünf beside finf began to appear already in the twelfth century, whence NHG. fünf. Beside NHG. fünf there was formerly in common use funf, funfzehn, funfzig, especially in North German. These forms are still common in some North German dialects. The final $\mathbf{n}$ in OHG. sibun, niun, and zëhan is due to the ordinal forms $(\S 161, \mathrm{I})$. OHG. einlif, zwelif, originally meant something like (ten and) one left over, (ten and) two left over, cp. Lithuanian vënúlika, eleven, dvýlika, twelve, \&c., where the lif and lika are from *liq- the weak form of the Indg. root *1eiq., to leave, and are ultimately related to OHG. lihhan, Goth. leikuan, to lend, Gr. $\lambda \epsilon i \pi \omega$, Lat. linquō, I leave. The assimilation of *.lih to $\cdot$ lif first took place in $z w e l i f$ because of the preceding labial ( $\$ 198$, note), and then, at a later period, the lif was extended to einlif for older *einlih. On NHG. elf see §139, and on zwölf, §92. The $z$ in OHG. drizëhan is due to the simplex zëhan and the compounds I4 to I9, otherwise it would have been *drizëhan in OHG., cp. drizug (\$ 217). In OHG. and MHG. forms with and without medial s existed side by side in the words for 16 and 60 ( $\$ 282)$. siebzehn and siebzig are the forms now in general use. In the words for 18 and 80 the $\mathbf{t}$ disappeared in $M H G$. by assimilation, but was often restored through the influence of acht, whence the NHG. forms with $t$. On the $a$ in zwanzig, see § 139.

$\$ 414$. The decades 20 to 60 were formed in prim. Germanic from the units 2 to 6 and the abstract noun *tezund'- = Indg. *dekmt'-, decade, whence the Goth. stem form tigu- which went over into the u-declension with a plural tigjus, as nom. twái tigjus, twenty, dat. twáim tigum $=$ OHG. zweinzug, the first element of which is 
also originally a dative. Prim. Germanic *tegund" is a derivative of prim. Germanic *texun. (= Indg. *dékm, Gr. Séka, Lat. decem, Goth. taíhun, OHG. zëhan) with the change of $x$ to $z$ by Verner's law ( $\$ 199)$ and the loss of the final consonants ( $\$ 161)$. The stem *tezu. regularly became -tig in OE. and OS., and *zig in OHG. The $\mathbf{u}$ in OHG. -zug is difficult to account for. It may have arisen from the assimilation of the first vowel to the second before the final -u disappeared. -zug was weakened to -zig (-zeg) in late OHG., whence M HG. -zic (-zec) and NHG. -zig.

In the oldest HG. the decades 70 to Ioo were sibunzo, ahtozo, *niunzo, zëhanzo, but from the early part of the ninth century they were remodelled on analogy with the decades 20 to 60 . sibunzo, \&c. are shortened forms for older *sibunzohund, *ahtozohund, *niunzohund, *zëhanzohund =Goth. sibuntēhund, ahtáutēhund, niuntē. hund, taíhuntēhund. Many attempts have been made to explain these forms, but no satisfactory explanation of their morphology has ever yet been given.

\$415. The usual form for one hundred is in OHG. zëhanzug, which was still common in MHG. down to the twelfth century. The form hunt for a single hundred does not occur until late OHG. In OHG. and early MHG. 200, 300, \&c. were regularly expressed by the units and the neut. noun hund (=Gr. ধ-кaróv, Lat. centum, Indg. ${ }^{*}$ kmtom). The form hundert (= O. Icel. hundrap, OE. hundred) does not occur in HG. until the twelfth century. The second element, -ert, -rap, -red, is related to Goth. rajjō, number. OHG. dūsunt, late OHG. also tūisent, was mostly a fem. noun, but also often neuter. In MHG. it was neut. as in NHG.

§416. In OHG. the decades 20 to Ioo, hunt, and dussunt were nouns and governed a following noun in the gen. case. In MHG. they were mostly used as uninflected adjectives as in NHG. 
$\S$ 417. In OHG. the numerals $I$ to 3 were declinable in all cases and genders as in the other Germanic languages.

$\S 418$. ein was declined according to the strong or weak declension of adjectives in OHG. and MHG. as in NHG., when declined weak in OHG. and MHG. it meant 'alone', and with the meaning 'only ones' pl. weak forms also occurred where in NHG. the inflected forms of einzig are used. The uninflected form ein was generally used for all genders in the nom., and in the acc. neuter, as ein man, frouwa; kind. In NHG. the fem. nom. acc. is always inflected. ein came to be used as an indef. art. already in OHG., but it was not used so frequently as such in OHG. as in MHG. and NHG. In all periods of the language it was accented or unaccented according as it was used as a numeral or indef. article.

§ 419. OHG. MHG. NHG.

Nom. Acc. Masc. zwēne

zwēne zwei,(zween)

" " Fem. zwā, (zwō) zwā,(zwō) zwei, (zwo)

" " Neut. zwei

Gen. all genders $z$ weio, zwei zwei (zweiero)

Dat. " , zweim, zweier zwei, (zweier) (zwein) zwein, zwei, (zweien)

(zweien).

The nom. acc. neut. zwei came to be used for the masc. and fem. in Middle German already in the MHG. period. The uninflected nom. acc. neut. zwei began to be used in MHG. for all genders and cases before a following noun. The gen. zweiero with adjectival ending became the regular form from late OHG. onwards, whence $\mathrm{MHG}$. and NHG. zweier. The nom. acc. zween, fem. zwo were common down to the eighteenth century, and are also sometimes found in nineteenth-century literature. 
$\S 420$.

OHG.

MHG.

NHG.

Nom. Acc. Masc. drì, (drie) drī, (drie) drei

" " $\quad$ Fem. drio

Gen. all genders drīo,(driero) drier

Dat. " "

drim, (drin) drin,

(drīe)n)

drei

drei

drei, (dreier)

drei,

(dreien)

Late OHG. and MHG. drie has adjectival ending. NHG. drei is regularly developed from the OHG. and MHG. masc. dri. The masc. dri came to be used for the fem. drio in late OHG., and in late MHG. the masc. dri came to be used for the neut.; and driu, which would have become *dreu in NHG., disappeared. dri (=NHG. drei) began to be used already in MHG. for all genders and cases before a following noun. The gen. driero with adjectival ending became the regular form from late OHG. onwards, whence MHG. drier and NHG. dreier. The dat. drien (=NHG. dreien) with adjectival ending beside drin is common from the twelfth century until towards the end of the MHG. period, then drin disappeared.

$\$ 421$. In OHG. and MHG. the numerals 4 to I2 remained uninflected when they stood before nouns, but were inflected when they stood after a noun, or were used as nouns. The nom. and acc. neut. had adjectival endings. The endings are :-

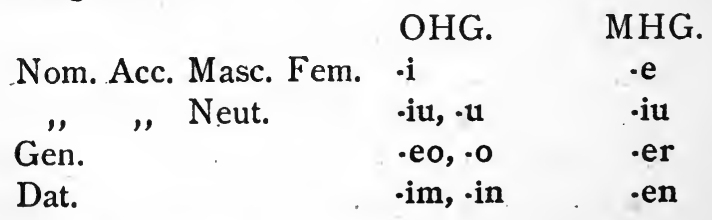

The OHG. endings, except for the nom. and acc. neut., are those of the $\mathbf{i} \cdot$ declension $(\S 373)$. The MHG. gen. ending $\cdot$ er is adjectival ( $(401)$.

The numerals I3 to I9 were also sometimes inflected 
after the analogy of the numerals 4 to 12 . In the case of I3 both elements could be inflected, but in 14 to 19 only -zëhan had inflexions.

When the cardinal numerals are inflected in NHG., they have -e in the nom. and acc., -er in the gen. (but -en when preceded by the def. article or a word declined like it), and -en in the dat. except sieben which does not take a second -en.

§ 422.

$\mathrm{OHG}$.

ēristo, furisto ander

dritto

feordo, fiordo

fimfto, finfto

sëhsto

sibunto

ahtodo

niunto

zëhanto

einlifto

zwelifto

drittozëhanto

fiordozëhanto

finftazëhanto

sëhstazëhanto

sibuntozëhanto

ahtodazëhanto

niuntazëhanto

zweinzugōsto

drīzugōsto

fiorzugōsto

finfzugōsto

sëh(s)zugōsto

2. Ordinal.

MHG.

ērste

ander

dritte

vierde

finfte, fünfte

sëhste

sibente, -de

ahtede, ahte

niunte, -de

zëhente, -de

$€$ i(n)lifte, eilfte

zwelfte

drizëhende

vierzëhende

fünfzëhende

sëh(s)zëhende sibenzëhende

ah(t)zëhende

niunzëhende

zweinzigeste

drizigeste

vierzigeste

fünfzigeste

sëh(s)zigeste
NHG.

erste

zweite

dritte

vierte

fuinfte

sechste

siebente

achte

neunte

zehnte

elfte

zwölfte

dreizehnte

vierzehnte

fünfzehnte

sechzehnte

siebzehnte

achtzehnte

neunzehnte

zwanzigste

dreissigste

vierzigste

fünfzigste

sechzigste 
OHG.

sibunzugōsto

ahtozugōsto

niunzugōsto

zëhanzugōsto

dūsuntōsto
MHG.

sibenzigeste

ah(t)zigeste

niunzigeste

$\left\{\begin{array}{l}\text { zëhenzigeste } \\ \text { hundert(e)ste }\end{array}\right.$

tūsent(e)ste
NHG.

siebzigste achtzigste neunzigste

hundertste

tausendste

The ordinals ēristo, furisto are old superlatives ( $\$ 412)$. OHG. and MHG. ander (= Goth. anpar, OE. oper, cp. Engl. every other day) was declined according to the strong declension in OHG., but in late OHG. also weak as in MHG. and NHG. ander with the meaning second was used down to the eighteenth century and is still preserved in anderthalb. zweite, a new formation from zwei after the analogy of the other ordinals, does not occur until the fifteenth century. Beside zweite the masc. form zweente, and fem. zwote, often occur in the eighteenth century and also occasionally in early nineteenth-century literature. The word for third had short $\mathrm{i}$ already in prim. Germanic, thus OHG. dritto (Goth. pridja, OE. pridda, Gr. трíros) with stem form from Indg. *tri-, the weak form of *trei., three.

The ordinals $4^{\text {th }}$ to 12 th were formed direct from the cardinals by means of the Indg. suffix -to and were declined according to the weak declension.

The ordinals $13^{\text {th }}$ to I 9 th were formed from the ordinals $3^{\text {rd to }} 9^{\text {th }}$ and the ordinal for Ioth (cp. also Goth. fimftataí. hunda, fifteenth), but only -zëhanto was inflected. In late OHG. the first ordinal of the compound was replaced by the cardinal, whence the MHG. and NHG. forms.

The ordinals 2oth to Iooth, and roooth, were formed from the cardinals and the superlative suffix -ōst. ( $\$ 408)$, whence the MHG. and NHG. forms.

In NHG. the ending te has been generalized from 
those forms where it was regular, as in erste, dritte, fünfle, zwanzigste, \&c., just as Modern Engl. has generalized the th from fourth onwards, as fifth, sixth, twelfth, OE. fifta, siexta, twelfta, \&c., whereas most Modern Engl. dialects have generalized the -t forms, as fourt, fift, sixt, twelft, \&c.

sibende, niunde, zëhende were the usual MHG. forms ( $\$ 268$ ). ahtede became ahte already in MHG., whence NHG. achte. The phonological remarks, which have been made concerning the cardinals, also apply to the ordinals.

\$ 423. In OHG. all the ordinals, except ander, were declined according to the weak declension of adjectives. In MHG. they were declined according to the weak or strong declension of adjectives, but without uninflected forms, just as in NHG.

\section{Other Numerals.}

$\$$ 424. In OHG. the multiplicative numeral adjectives were formed from the cardinals and the Germanic suffix for -fold (Goth. -falps, OE. -feald, OHG. -falt), as einfalt, zwifalt, drifalt, fiorfalt, finffalt, sëhsfalt, sibunfalt, ahto. falt, niunfalt, zëhanfalt, \&c. (= OE. ānfeald, twiefeald, priefeald, \&c.), which were declined as ordinary adjectives. From -falt there was formed in late OHG. the suffix -faltig (= MHG. -veltic, -valtic, NHG. -fältig), as ein. faltig, zwifaltig, drifaltig, fiorfaltig, \&c. = MHG. ein. veltic, zwiveltic, driveltic, vierveltic, \&c., NHG. einfältig with changed meaning; zweifältig, dreifältig, are new formations from $z$ wei and drei; vierfältig, \&c.

In the MHG. period multiplicative numeral adjectives began to be formed from -fach (=OE. fæc), part, division of space or time, as einfach, zwifach, drifach, vierfach, \&c., whence NHG. einfach, vierfach, \&c.; zweifach (older 
NHG. zwiefach) and dreifach are new formations from zwei, drei ; cp. also mannigfach, mehrfach, vielfach.

Of the three MHG. forms -fach, -valt, -veltic, the form -valt ceased to be used in this connexion in late MHG., and in NHG. the form -fach is the usual one; failtig is now archaic. Beside zweifach we also have doppelt ( $\$ 272)$ with differentiated meanings.

\$425. The adverbial multiplicatives were in OHG. eines (gen. of ein) which was in common use in the form eins down to the beginning of the nineteenth century. zwiro, MHG. zwir, early NHG. zwier, now practically obs. driror was rare already in OHG., the usual form was drio stunt, the stunt being properly an old fem. noun used adverbially; vior stunt, finf stunt, \&c. In the thirteenth century mãl (Engl. meal in piecemeal, meal. time) began to be used with the same meaning as stunt, and then at a later period stunt became obs., whence NHG. einmal, zweimal, dreimal, \&c.

$\$$ 426. The NHG. suffix -lei was in MHG. a fem. noun which only occurred in the gen. case, as einer leie, drier leie, vier leie, aller leie, maneger leie, \&c., whence NHG. einerlei, zweierlei, dreierlei, viererlei, allerlei, mancherlei, vielerlei, \&c. MHG. leie, lei, way, manner, is a loan-word from Old Provençal ley (nom. lei-s, ley.s), Lat. acc. lēgem.

\$427. MHG. anderhalp, drittehalp, vierdehalp, fünftehalp, \&c., lit. (one and) the second half, (two and) the third half, \&c., whence NHG. anderthalb, dritt(e)halb, viert(e)halb, \&c. This method of expressing numbers goes back to the prim. Germanic period, and was originally common in all the Germanic languages. Originally both elements of the compound were inflected, but at a later period the compound, when used before nouns, became uninflected like other cardinal numerals. Cp. OE. oper healf hund daga, I50 days; pridda healf, two and a half; 


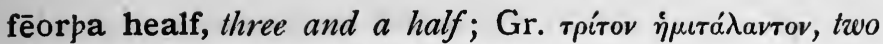
talents and a half, lit. third half talent.

§ 428. MHG. sëlbe ander, sëlbe dritte, sëlbe vierde, $\& c$, where sëlbe is the weak form of the nom. sëlp, later written in one word sëlbander, sëlbdritte, sëlbvierde, whence NHG. selbander, lit. self as second, selbdritt, selbviert, \&c., as selbdritt erschien der wolf (Lessing), cp. Gr. тpíros aủrós, lit. himself as third = himself with two others,

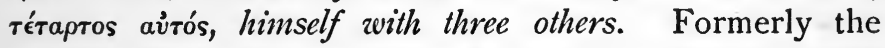
cardinals were also occasionally used, as selbdrei, selb. vier, \&c.

\$ 429. In OHG. beide was declined according to the strong declension of adjectives and had plural forms only. In MHG. it began to have singular forms after the analogy of iewëder, iedewëder, each. In NHG. it came to be treated as an ordinary adjective and accordingly has strong and weak forms singular and plural. $\mathrm{Cp}$. the isolated form beiderseits, older NHG. beiderseit $=$ MHG. ze beider zit.

$\$$ 430. NHG. erstens, zweitens, drittens, viertens, \&c., are modern formations from the weak gen. of the ordinals, to which has been added the so-called adverbial gen. ending $\cdot \mathbf{s}$.

\section{CHAPTER XVI}

\section{PRONOUNS}

\$ 431. THE most difficult chapter in works on comparative grammar is the one dealing with the pronouns. It is impossible to state with any degree of certainty how many pronouns the parent Indg. language had and what forms they had assumed at the time it became differentiated into the various branches which constitute the Indg. family of languages. The difficulty is rendered still more com- 
plicated by the fact that most of the pronouns, especially the personal and demonstrative, must have had accented and unaccented forms existing side by side in the parent language itself; and that one or other of the forms became generalized already in the prehistoric period of the individual branches of the parent language. And then at a later period, but still in prehistoric times, there arose new accented and unaccented forms side by side in the individual branches, as e.g. in prim. Germanic ek, mek beside ik, mik. The separate Germanic languages generalized one or other of these forms before the beginning of the oldest literary monuments and then new accented beside unaccented forms came into existence again. And similarly during the historic periods of the different languages. Thus, e. g., the $\mathrm{OE}$. for $I$ is ic ; this became in $M E$. ich, accented form, beside $i$, unaccented form; ich then disappeared in standard ME. (but it is still preserved in one of the modern dialects of Somersetshire) and $\mathbf{i}$ came to be used as the accented and unaccented form. At a later period it became $\bar{i}$ when accented and remained $i$ when unaccented. The former has become NE. I, and the latter has disappeared from the literary language, but it is still preserved in many northern Engl. dialects, as $i$. In these dialects $\mathbf{i}$ is regularly used in interrogative and subordinate sentences; the ME. accented form $\bar{i}$ has become ai and is only used in the dialects to express special emphasis, and from it a new unaccented form a has been developed which can only be used in making direct assertions. Thus in one and the same dialect (Windhill, Yorks.) we arrive at three forms : ai, a, i, which are never mixed up syntactically by genuine native dialect speakers. Something sinilar to what has happened and still is happening in the modern dialects must also have taken place in the prehistoric and historic periods of all the Indg. languages; hence in the prehistoric forms 
of the pronouns given below it must not be assumed that they were the only ones existing in prim. Germanic. They are merely given as the nearest ascertainable forms from which the OHG. forms were descended.

\section{Personal.}

$\S 432$.

First Person.

\section{OHG. MHG.}

Sing. Nom. ih

Acc. mih

Gen. min

Dat. mir

Pl. Nom. wir

Acc. unsih

Gen. unsēr

Dat. uns

$\S 433$.

Sing. Nom. dū, du

Acc. dih

Gen. din

Dat. dir

Pl. Nom. ir

Acc. iuwih

Gen. iuwēr

Dat. iu

ich

mich

$\min$

mir

wir

unser

uns dū, du

dich

dīn

dir

ir

iuch

iuwer

iu

uns, (unsich)

Second Person.

NHG.

ich

mich

meiner, (mein)

mir

wir

uns

unser, (unsrer)

uns

$\$$ 434. In the parent language the nom. was rarely used except to express emphasis (cp. Skr., Lat., Gr.), because it was sufficiently indicated by the personal endings of the verb. Beside the accented form of each case of the personal pronouns, there also existed one or more unaccented forms just as in many modern dialects, where we often find three or even four forms for the nom. case of each pronoun. With few exceptions all the OHG. forms 
of the first and second persons represent prim. Germanic unaccented forms. The accented forms corresponding to OHG. ih, mih, dih occur, e.g., in O.Icel. ek, and OE. mec, pec.

The $\mathbf{h}$ in OHG. mih, dih, sih goes back to a prim. Germanic particle, ${ }^{*} \mathrm{ke}=$ Indg. ${ }^{*} \mathrm{ge}$, which is found in Gr. pronominal forms like '̇ $\mu$ '́ $\gamma \epsilon$.

On the OHG. forms with final $\mathbf{r}$ from prim. Germanic $\mathbf{z}$ see $\$ 161,(3)$.

OHG. unsih and iuwih have ih from the analogy of the sing. mih, dih.

The pl. acc. unsih and dat. uns were pretty well kept apart in OHG., in MHG. unsich was rarely used, and in NHG. the old dat. uns is now always used for the acc. as well.

The origin of the $\overline{\mathrm{e}}$ in unsēr, iuwēr is difficult to explain. It may partly be due to the fact that these genitives were also used in OHG. as the nom. sing. of the possessive pronouns and that they have eerr from the adjectival ending as in blintēr (\$ 402).

du was often used enclitically in OHG. and MHG. just as it is in the NHG. colloquial language, as OHG. nimis du? became nimistu? = NHG. nimstə?; bis du? became bistu? = NHG. bistə? This is the origin of the final $\mathbf{t}$ in the second pers. sing. of verbs. The $\mathbf{t}$ came to be regarded as part of the verb, so that we find already in OHG. forms like nimist du? beside nimistu? NHG. du is from the MHG. unaccented form du. MHG. dū would have become *dau in NHG.

OHG. ir has $\mathbf{i}$ for $\mathbf{u}$ after the analogy of wir. The prim. Germanic form was jŭz, cp. Goth. jus. From about the thirteenth century onwards the plural form ir came to be used for the second pers. sing. as the most usual form of politeness. It is still so used by country people amongst themselves, and by people of ' high degree' 
when they wish to avoid the familiar form $\mathrm{du}$ and the respectful form Sie.

OHG. iuwih became iuch about the end of the eleventh century. In MHG. iu (\$ 232) and iuch were kept pretty strictly apart until the fourteenth century. From then onwards iuch began to take the place of iu, especially in Middle German. And the old dat. form disappeared in early NHG.

Beside the gen. min, din there existed in OHG. and MHG. mines, dines in combination with sëlbes, ipsius, as mines sëlbes lip, lit. the body of myself. In MHG. beside mines, dines sëlbes there also existed miner, diner sëlbes, presumably at first only in connexion with fem. nouns; but the MHG. gen. pl. unser, iuwer were also an important factor in the origin of the forms miner, diner sëlbes. About the fourteenth century, they came to be used alone and regularly became meiner, deiner in NHG. The NHG. genitives mein, dein, unser, euer are regularly developed from the corresponding OHG. and MHG. forms. The old forms mein, dein are still used in poetic diction, as Wie könnt' ich dein vergessen! Dein denk' ich allezeit; cp. also vergissmeinnicht. In the pl. unser and euer are the usual NHG. forms, as Vergesst unser nicht (Goethe); Ihr zeigtet selten beherrschung euer selbst (Schiller). But the longer forms with er from the analogy of the adjectival endings are pretty common in the literature of the eighteenth and early nineteenth centuries, as Gedenken Sie unsrer (Goethe); Eurer, wahrlich hätt' ich nicht gefehlt (Schiller).

$\$ 435$. The only trace of a dual in OHG. is unkēr, of us two, in the combination unkēr zweio (Otfrid). In thirteenthcentury Bavarian occur ez, ye two, dat., acc. enk, also a possessive enker, still preserved in the modern Bavarian dialects. 


\section{Third Person.}

$\S$ 436. The pronoun of the third person is formed from two stems which are etymologically unconnected, viz. iand si-, (perhaps also sjā), as Lat. nom. masc. is = Goth. is, OHG. ër (ir); neut. Lat. id = Goth. it-a, OHG. iz; fem. Gr. $\stackrel{q}{l}$, Irish $\mathbf{s i}=$ Goth. si, OHG. sī; and perhaps OHG. siu = Skr. syâ. But many of the OHG. forms are new formations.

$\S 437$.

\section{Masculine.}

\section{OHG. MHG.}

Sing. Nom. ër, (ir) ër

Acc. inan, in in

Gen. $\sin$

Dat. imu, (-o)

Pl. Nom. Acc. sie

Gen. iro

Dat. im, in
NHG.

er

ihn

sin, (ës) seiner,(sein)

$\operatorname{im}(e) \quad i h m$

sie, sī, si sie

$\operatorname{ir}(\mathrm{e})$

in ihrer

ihnen

\section{Feminine.}

Sing. Nom. siu; sī, si siu; sī, si, sie sie Acc. sia, sie si, sī, sie sie Gen. ira; iru, $(-0) \operatorname{ir}(e) \quad$ ihrer Dat. iru, $(\cdot 0) \quad \operatorname{ir}(\mathrm{e}) \quad \mathrm{ihr}$

Pl. Nom. Acc. sio sie, sī, si sie Gen. iro ir(e) ihrer Dat. im, in in ihnen

\section{Neuter.}

Sing. Nom. Acc. iz

Gen. is, ës

Dat. imu, $(\cdot 0)$

Pl. Nom. Acc. siu

Gen. iro

Dat. im, in ëз

ës

$\operatorname{im}(e)$

siu; sī, si, sie sie $\operatorname{ir}(\mathrm{e})$

in es

seiner,(sein)

ihm

inrer

ihnen. 
§ 438. Masculine sing. : The oldest form of the nom. is ir which is rare except in Isidor. The general form is ër with ë from dër. Beside ër some OHG. Franconian monuments have hër, he $=\mathrm{OE}$. hĕ, the instrumental case of which has been preserved in NHG. heute $=$ OHG. hiu-tu from *hiu tagu. in-an with adjectival ending ( $\$ 401)$ is the accented form. in came to be used for the accented and unaccented form in the ninth century. In NHG. it has been lengthened. The gen. of ër would be *is, but it disappeared in prehistoric HG., its place having been taken by the reflexive pronoun sin. In MHG. the neut. ës was sometimes used for the masc. gen. The origin and use of NHG. seiner (sein) is parallel with that of meiner (mein), § 434.

In the dat. imu is the older form, which regularly became imo in the ninth century. ime, the weakened form of imo, regularly became im during the MHG. period, which has been lengthened to ihm in NHG. ( $\$ 109)$.

\$ 439. Feminine sing. : siu is the usual nom. form in the oldest HG. It is either the same word as Skr. syâ or has its iu from the nom. fem. of the simple demonstrative pronoun $(\$ 449)$. siu, which would have become *seu in NHG., disappeared in late MHG. sī, si are not common until towards the end of the OHG. period, the former being the accented, and the latter the unaccented form. si, which would have become *sei in NHG., disappeared in late MHG. NHG. sie is from MHG. sie or from the lengthened form of si. The OHG. acc. forms sia, sie were due to the influence of dia, die $(\$ 449)$. In late OHG. sia was sometimes used for the nom., and in MHG. the nom. was often used for the acc. and vice versa. NHG. acc. sie is of the same origin as the nominative.

In OHG. the gen. and dat. forms ira, iru (with original instrumental ending) often interchanged with each other 
like the corresponding forms of the adjectives ( $\$ 402)$. MHG. ir(e) is regularly developed from the corresponding OHG. forms. ir(e) became ir during the MHG. period ( $\$ 171)$, which has been lengthened to ihr in NHG. The NHG. gen. ihrer is of the same origin as meiner $(\$ 434)$. The gen. ihr existed beside ihrer until about the end of the seventeenth century.

$\$$ 440. Neuter sing. : In OHG. the regular form for the nom. and acc. is iz. In late OHG. and early MHG. ëz existed beside iz, the former being the unaccented and the latter the accented form. Then is disappeared in MHG. and ë $3=$ NHG. es became the accented form.

In the gen. is is the old accented form and ës the unaccented. is disappeared in late OHG. ës was rarely used in MHG.; and in NHG. it has only remained in such sentences as ich bin es satt, zufrieden, \&c. The chief reason why es disappeared from general use was the fact that it fell together with the non. acc. es (MHG. ëz) in late MHG. For the old gen. is, ës, the reflexive form sin began to be used already in late OHG. In early MHG. ës was only used in reference to a sentence, and $\sin$ in reference to a noun or a pronoun representing a noun. On seiner (sein) and the dat. forms see above.

\$ 441. Plural: The nom. and acc. sie, sio, siu were special OHG. formations from the fem. sing. stem si., to which were added the nom. pl. endings of the adjectives $(\$$ 401). This took place in prehistoric HG. The fem. nom. acc. was first formed on analogy with the sing., and then this was followed by the formation of the masc. and neuter. sie was seldom used for the fem. pl. sio in OHG. In late OHG. sie was used for both the masc. fem. and neuter. On the other hand the original neut. form siu came to be used for the masc. and fem. in MHG. In late MHG. si and siu, which would have become *sei and *seu in NHG., disappeared, and sie or the lengthened 
form of si became NHG. sie. This is now also used for the second person. It was originally used in reference to plural abstract nouns like eure gnaden, and then, since the seventeenth century, it has come to be used for ihr generally, see $\S \mathbf{4 3 4}$.

The gen. iro regularly became ir during the MHG. period ( $\$ 171)$, which became lengthened to ihr in early NHG. ( $(103)$. ihr has regularly been replaced by ihrer with adjectival ending since the end of the seventeenth century.

Examples of ihr are: Sind ihr nit zehn rein worden? (Luther); Es werden ihr sechs statt drei (Opitz); but Goethe ihrer fünfzig. ihr is still preserved in NHG. before the gen. aller, as Ihr aller glïckwünsche empfing ich. Beside the fem. gen. sing. and pl. íro there existed in OHG. iró with end accentuation. The former regularly became MHG. ir(e), NHG. ihr, and the latter MHG. iro, and possibly NHG. ihro still used in Court and official language. It is more probable however that ihro is a NHG. formation after the analogy of the archaic form dero ( $\$$ 453). It is used for the second person masc. and fem., as ihro eminenz, durchlaucht; Es hat ihro gnaden nicht gereut; ihro majestät gestatten gnädigst; \&c.

The dat. im became in in the ninth century. in then remained during the OHG. and $\mathrm{MHG}$. period; but beside in there arose in the twelfth and thirteenth centuries inen with adjectival ending. The form in disappeared in early NHG. and inen regularly became ihnen in NHG. (\$108).

\section{Reflexive.}

$\$$ 442. The reflexive pronoun originally referred to the chief person of the sentence (generally the subject), irrespectively as to whether the subject was the first, second, or third person singular or plural. This distinction has 
remained in Sanskrit, but in the Germanic languages the pronouns of the first and second person came to be used reflexively already in prim. Germanic, and then the original reflexive pronoun became restricted to the third person.

$\S 443$.

Singular.

$\begin{array}{llll} & \text { OHG. } & \text { MHG. } & \text { NHG. } \\ \text { Acc. } & \text { sih } & \text { sich } & \text { sich } \\ \text { Gen. } & \text { sin; ira } & \text { sin; ir(e) } & \text { seiner, (sein); ihrer } \\ \text { Dat. } & \text { imu; iru } & \text { im(e); ir(e) } & \text { sich }\end{array}$

Plural.

$\begin{array}{llll}\text { Acc. } & \text { sih } & \text { sich } & \text { sich } \\ \text { Gen. } & \text { iro } & \text { ir(e) } & \text { ihrer } \\ \text { Dat. im, in } & \text { in } & \text { sich }\end{array}$

\$ 444. In prim. Germanic there existed the accented form ${ }^{*}$ sek beside the unaccented form ${ }^{*}$ sik. OHG. sih represents the latter. The se in *sek corresponds to Gr. $\ddot{\epsilon}$, Lat. sê, and the $\mathbf{k}$ is from the Indg. particle *ge (\$ 434). In late OHG. and in MHG. sich was sometimes used for the dat., especially after prepositions. In early NHG. sich came to be used for the dat. generally. All the forms, except sich, are the same as those of the personal pronoun third person $(\$ 437)$.

\section{Possessive.}

\$ 445. In OHG. the possessive pronouns of the first and second persons were formed from the gen. case of the corresponding personal pronouns, thus min, $m y$; din, thy; unsēr, our; iuwēr, your; and the masc. and neut. of the third pers. sing. was formed from sin, his, its. These were all declined in OHG., as in MHG. and NHG., according to the strong declension of adjectives ( $\$ 401)$. Note that the OHG. inflected forms of unsēr, iuwēr are: unserēr, unseriu, unseraz, \&c.; iuwerēr, iuweriu, iuweraz, 
\&c. In OHG. and MHG. the uninflected forms were almost always used for the nom. sing. masc. and fem., and the nom. acc. neuter. In NHG. the nom. masc. sing. and the nom. acc. neut. sing. remain uninflected when used as possessive adjectives, but the fem. sing. is always inflected when used as a possessive adjective.

§ 446. The third pers. fem. sing. was expressed by ira (\$ 437), lit. of her, and the third pers. pl., all genders, by iro (\$ 437), their, lit. of them. ira and iro were uninflected in OHG., but in early MHG. they were often inflected on analogy with the other possessives, and from the fourteenth century onwards the inflected forms became general just as in NHG. ihr, ihre, ihres, pl. ihre.

$\$$ 447. The possessive pronouns der meinige, deinige, seinige, \&c., did not exist in MHG. They are NHG. formations with the adjectival suffix $\cdot$ ig $(\$ 322)$.

\section{Demonstrative.}

§ 448. In the parent Indg. language the nom. sing. masc. and fem. of the simple demonstrative was *so, ${ }^{*}$ sā $=$ Gr. $\dot{\delta}, \dot{\eta}$, Goth. sa, sō. All the other cases of the sing. and pl. were formed from the stems to., tā., as acc. Gr. $\tau o ́ v, \tau \eta^{\prime}$, Lat. is-tum, is-tam, Goth. fan-a, pō; nom.

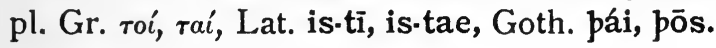

$\S 449$.

Masculine.

\section{OHG.}

Sing. Nom. dër

Acc. dën

Gen. dës

Dat. dëmu, $(\cdot 0)$
MHG. NHG.

dër der

dën den

dës des,(dessen)

dëm(e) dem

die

Gen. dëro

dër(e) der, (deren,

derer)

Dat. dēm, dēn

dën den, (denen) 
Feminine.

\section{OHG. MHG. NHG.}

Sing.

Nom. diu

Acc. dea, dia, die

Gen. dëra, dëru, $(\cdot 0)$

Dat. dëru, $(-0)$

Pl. Nom. Acc. deo, dio

Gen. dëro

Dat. đēm, dēn

\section{Neuter.}

Sing. Nom. Acc. daz

Gen. dës

Dat. dëmu, (.o)

Instr. diu

Pl. Nom. Acc. diu

Gen. dëro

Dat. đēm, đēn diu die

die die

dër(e) der, (deren,

derer)

dër(e) der

die

die

dër(e) der, (deren,

derer)

dën den

daz das

dës des, (dessen)

dëm(e) dem

diu die

dër(e) der, (deren,

derer)

dën den

§450. Masc. sing.: đër was formed from *pe (the unaccented form of $p \bar{e}=O S$. the $\bar{e})+$ the nom. sign $r$, as in the pronoun ër. The acc. dën beside Goth. pan-a has ë from the gen. dës. The gen. dës is from an Indg. form *teso $=$ Goth. pis. The dat. dëmu is from an old instrumental form *temō. On forms like OHG. zëmo, zëm, MHG. zëm(e), NHG. zum, see $\$ 274$.

§ 451. Fem. sing. : The OHG. and MHG. nom. diu had iu from the pronoun siu (\$ $\$$ 437). It would have become *deu in NHG., but in MHG., especially in Middle German, the acc. form came to be used for the nom. and vice versa. NHG. die is the old acc. form. The oldest form of the 
acc. must have been ${ }^{*}$ e $\bar{e}$ in prehistoric HG., which regularly became dea, dia, die during the OHG. period (§ 71). NHG. die is regularly developed from OHG. and MHG. die. The gen. dëra = Goth. pizōs is from an original form *tesās. The dat. dëru is from an Indg. instrumental form ${ }^{*}$ tesā $=$ prim. HG. ${ }^{*}$ pezō. In ninthcentury OHG. the dat. form was often used for the gen., and in late $O H G$. dëro was regularly used for both cases, from which MHG. dër(e) and NHG. der are the normal development.

\$ 452. Neut. sing. : The nom. and acc. daz $=$ OE. pæt, Goth. pat.a, from an original form ${ }^{*}$ tod $=\mathrm{Gr}$. ró, Lat. is-tud. The instr. diu from an original form *tjố was used with nouns in the oldest HG., as mit diu vuiru, with fire. Beside the accented form diu there existed in OHG. and MHG. the unaccented forms de, te. The old instrumental has been preserved in NHG. desto (OHG. dës diu, later dës de, te, MHG. dëste). On the gen. and dat. forms, see above.

\$ 453. Plural: The original form of the nom. masc. was *toi = Gr. $\tau o i$, Lat. is.tī, Goth. pái. In unaccented syllables prim. Germanic *bai became pē in prehistoric HG. This è, which was close, fell together with prim. Germanic $\overline{\mathbf{e}}$ and regularly became ea, ia, ie during the OHG. period ( $(71)$. de still occurred in the oldest HG. The MHG. and NHG. die is regularly developed from OHG. die.

The original form of the masc. acc. was *tons $=\mathrm{Gr}$. (Cretan dialect) róvs, Goth. pans, but already in prehistoric HG. the nom. was used for the acc.

The nom. fem. deo, dio is from an original form *tjẵs = Skr. tyās, prim. Germanic * ${ }^{*} j \mathrm{j}$ s.s. deo, dio regularly became die during the OHG. period, whence MHG. and NHG. die. The original form of the acc. fem. was *tāns $=$ Gr. (Cretan dialect) távs with regular shortening 
of the $\overline{\mathbf{a}}$. But the nom. was used for the original acc. already in prim. Germanic.

The nom. acc. neut. diu, from an original form ${ }^{*}$ tjō $=$ Vedic Skr. tyâ,, remained in OHG., but in MHG. the masc. form die came to be used for diu, and from the end of the MHG. period onwards die became the regular form.

The original form of the gen. pl. was *toisōm, which in OHG. would have become *deiro (= O.Icel. peira, OE. pāra), but OHG. dëro has ë for ei from the gen. sing. dës. dëro regularly became dër(e) in $\mathrm{MHG}$. and der in $\mathrm{NHG}$. Beside OHG. déro there also existed a form dëró with end accentuation, whence MHG. dëro, and NHG. dero, still used in legal and official language in reference to the third person and also occasionally in reference to the second, as Ich ging vergniigt von der unterredung mit dem fürsten weg und werde dero herablassung nie vergessen; Geruhen Sie, mein haus zu beehren mit dero gegenwart.

The original form of the dat. was probably *toimis (instrumental) which became in prim. Germanic * paimiz = Goth. páim, OE. pǣm, OHG. dēm, dēn, cp. nom. pl. masc. dē. dēm became dēn in the ninth century, which was shortened to dën in late OHG., whence $\mathrm{MHG}$. dën and NHG. den.

§454. The NHG. short forms der, die, das, \&c., are unaccented when used as the def. article, and accented when used as pronouns. Beside the unaccented forms der, die, das, \&c., there arose in the fifteenth century the accented forms dessen, deren (derer), dessen with adjectival endings. These new formations are not common in Luther. At first no difference in meaning or use existed between the short and lengthened forms. They were both in common use as cases of the def. article in the eighteenth century. But they gradually became differentiated in use and meaning. The lengthened forms are now 
always used as pronouns. The gen. fem. sing. derer is now obsolescent. It is, however, sometimes used by the most modern novelists.

$\$$ 455. The compound demonstrative pronoun 'dieser' is composed of the simple demonstrative and the particle se. Originally the first element only was inflected, as nom. sing. masc. dë-se, gen. dës-se, nom. pl. masc. dë-se. At a later period the se came to be inflected also, as gen. masc. sing. dës-ses. And lastly the first element ceased to be inflected, and the second element took in most cases the ordinary endings of the simple demonstrative, as dat. dë-semu, \&c. In those cases which had the ending iu in OHG., the ë of the stem became $\mathbf{i}$ in the ninth century. Then in the eleventh century the $i$ was transferred to all the cases by levelling out the di- forms, as nom. disēr (dirro), disiu; gen. disses, dirro; dat. disemo, dirro; pl. masc. nom. acc. dise, \&c., whence all the $\mathrm{MHG}$. forms with i. In passing from MHG. to NHG. this $\mathbf{i}$ was regularly lengthened to 1 written ie $(\$ 109)$.

In the masc. nom. sing., the fem. gen. and dat. sing., and the gen. pl., the $\mathbf{s}$ often became assimilated to the $\mathbf{r}$, partly with loss of e, thus as early as the ninth century dësēr, dësera, dëseru, dësero became dërēr, dërera (dërra), dërero (dërro), whence the MHG. forms with rr. The MHG. masc. nom. sing. was an analogical formation after these forms.

$\S 456$.

Masculine.

OHG. MHG. NHG.

Sing. Nom. dëse, dësēr dirre dieser

Acc. dësan disen diesen

Gen. dësses dises dieses

Dat. dësemu, (-o) disem(e) diesem

$P l$. Nom. Acc. dëse dise diese

Gen. dësero dirre dieser

Dat. dësēm, (-ēn) disen diesen 


\section{Feminine.}

OHG. MHG. NHG.

Sing. Nom. dësiu, disiu disiu diese

Acc. dësa dise diese

Gen. dësera dirre dieser

Dat. dëseru dirre dieser

Pl. Nom. Acc. dëso

Gen. dësero

dise

Dat. đësēm, (-ēn) disen

\section{Neuter.}

Sing. Nom. Acc. diz ditze, diz, diz dieses,

(dies)

Gen. dësses dises dieses

Dat. dësemu, (-o) disem(e) diesem

Pl. Nom. Acc. dësiu, disiu disiu

Gen. dësero dirre

diese

Dat. dësēm, (-ēn) disen

dieser

diesen

$\S$ 457. Masc. sing. : The nom. dësēr and acc. dësan have adjectival endings ( $\$ 401)$. The real old gen. dësse is rare in OHG. It occurs occasionally in MHG. disse beside the usual form dises with single $\mathbf{s}$ from the acc. and dative. In OHG. dësses both elements are inflected, whence the double ss. The NHG. nom. dieser is a new formation with $\mathbf{s}$ from the other forms of the singular.

Instead of dieses, the usual gen. sing. masc. and neut., the form diesen, with the weak ending of adjectives, is sometimes used; and similarly jenen, solchen for jenes, solches. But such forms are not considered good German.

\$ 458. Fem. sing. : In MHG. the acc. came to be used for the nom., whence NHG. nom. acc. diese. Beside the 
usual MHG. form dirre there also existed diser with s from the nom. and acc., whence NHG. dieser.

\$ 459. Neut. sing. : Nom. acc. diz from *petti which by the assimilation of ts to tt may represent the O.Norse runic inscriptional form patsi. Beside diz there also existed in OHG. dizi (thizi), whence MHG. diz beside ditze. MHG. diz and late MHG. disez were new formations with adjectival endings $(\$ 401)$, whence $N H G$. dies, dieses. The old instrumental disappeared already during the OHG. period.

$\$$ 460. Plural: All the cases of the plural have adjectival endings ( $\$$ 401). Beside the usual gen. dirre MHG. also had diser, whence NHG. dieser.

§ 461. In OHG. jenēr (MHG. jener) was declined like a strong adjective just as in NHG. Then as now it had no uninflected forms. In MHG. it was declined like a strong adjective even when preceded by the def. article (dër jener), but in the fifteenth century it came to have also weak forms in this position (der jene), which occasionally occur down to the eighteenth century. From der jene was formed in the sixteenth century der jenige (written at first in two words) with the adjectival suffix -ig as in der meinige, \&c.

§ 462. NHG. selbst (MHG. sëlbes) is an old gen. with excrescent $\mathbf{t}$ ( $\$$ 272), and selber (OHG. sëlbēr, MHG. sëlber) is the old nom. masc. singular. selber remains uninflected in NHG. except when used instead of derselbe. In OHG. and MHG. sëlb, ipse, self, was regularly declined according to the strong and weak declension of adjectives. In conjunction with the def. art. it was declined weak as in NHG., as OHG. dër sëlbo, diu sëlba, daz sëlba = NHG. derselbe, dieselbe, dasselbe. derselbige is a NHG. formation from selb with the adjectival suffix -ig (\$ 322). In the seventeenth and eighteenth centuries it was far more common than derselbe, but it is now rarely if ever used. 
§463. OHG. solīh, MHG. solich, solch (inflected form solher) were declined like the strong declension of adjectives, but the nom. sing., all genders, generally remained uninflected. In NHG. solch is declined like a strong adjective when not preceded or followed by the indef. article. When followed by the def. art. it remains uninflected, but when preceded by it it is inflected like an ordinary adjective.

\section{Relative.}

$\S$ 464. A relative pronoun proper did not exist in prim. Germanic. The separate Germanic languages expressed it in various ways. In Goth. it was expressed by the simple demonstrative in combination with the relative particle ei ; in OE. by the particle pĕ in combination with or without the simple demonstrative; and in O.Norse by the particles sem and es (later er) in combination with the simple demonstrative. In OHG. and $\mathrm{MHG}$. it was generally expressed by the simple demonstrative as in NHG. See $\$ 449$.

For the first and second persons the rel. pronoun was expressed in OHG. and MHG. by the personal pronouns and the particles dār, dā, dar, as OHG. Fater unser, dū dār bist in himile. But in MHG. dër also came to be used with the personal pronouns as in NHG., as Vater unser, der du bist in himmel (Luther).

The indefinite rel. was expressed in OHG. by sō wër sō, sō wëlīh sō, whoever, sō waz sō, whatever. The second sō was omitted from the ninth century onwards, and sō wër, sō wëlīh, sō waß became swër, swëlich, swaz in early MHG., but by the end of the MHG. period these pronouns had disappeared, and their place was taken by the simple interrogatives wër, wëlich (wëlch), waß, which came to be used as relatives in the fourteenth century. The old gen. wes was common in early NHG., 
as Wes das herże voll ist, des gehet der mund über (Luther). In late MHG. sō was also used as a rel. pronoun for the nom. and acc. sing. and pl., as Von priesterlichem ampte, sō wir haben von gote. It is very common in Luther and still often occurs in sixteenth, seventeenth, and eighteenth century literature. It is now obsolete except in poetry, as Heilig ist das gesetz, so dem künstler schönheit bietet (Schiller). The details, concerning the use of the above words as relative pronouns in the various periods of the language, belong to syntax.

\section{INTERROGATIVE.}

\$ 465. The parent Indg. language had two stems from which the interrogative pronoun was formed, viz. qo- and qi- with labialized $q(\$ 108)$. The former occurs in Gr.

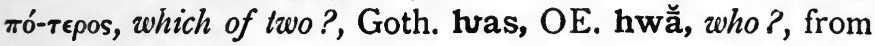
an original form *qos ; Lat. quod, Goth. hua, OE. hwæt, OHG. hwaz, from an original form *qod. And the latter occurs in Gr. rís, Lat. quis, and possibly in OHG. hwër, who?, from an original form *qis.

$\$$ 466. The OHG. simple interrogative pronoun had no independent forms for the feminine, and was declined in the singular only. The initial $\mathbf{h}$ disappeared in OHG. at the beginning of the ninth century ( $\$ 278)$.

Masculine and Feminine.

\section{OHG. \\ MHG. NHG.}

Nom. hwër, wër

Acc. hwënan, wënan, wën wën wen

Gen. hwës, wës wës wessen(wes)

Dat. hwëmu, wëmo wëm(e) wem

Neuter.

Nom.Acc. hwaz, waz

Gen. hwës, wës

Dat. hwëmu, wëmo

Instr. hwiu, wiu

waz was

wës wessen(wes)

wëm(e)

wiu 
\$ 467. From a comparison of OHG. hwër, hwënan, and hwëmu with the corresponding forms of the other Germanic languages, it is probable that the OHG. ë was due to levelling out the stem of the gen. hwës = Indg. *qeso.

The acc. hwënan with adjectival ending regularly became wën in late OHG. On the lengthening of the e in NHG. wer, wen, wem, see $\$ \$ 103,108$. On the origin of NHG. wessen, see $\$ 454$. The old gen. wes is now seldom used. It occurs in weshalb, weswegen. The old dat. and acc. neut. when depending on a preposition are generally expressed in NHG. by wozu, wovon, womit, \&c. was für ein, originally only acc., first occurs in the fifteenth century, and is very common in Luther. The instr. wiu, which would have become *weu in NHG., disappeared in late $\mathrm{MHG}$.

§ 468. OHG. hwëlīh (MHG. wëlch), Goth. hvileiks, was formed from the pronominal stem hwi- (= Indg. *qi.) and the suffix $\cdot 1$ in. In OHG. it was declined like a strong adjective just as in MHG. and NHG.

\section{INDEFINITE.}

\$469. From the list given below are omitted the pronouns which became obsolete in OHG. and MHG.

all, OHG. al, inflected form allēr ; ander, OHG. ander, inflected form anderēr; ein, OHG. ein, inflected form einēr; einige, OHG. einige; etlich, MHG. ëtelīh, now only used in pseudo-archaic language, supplanted by einige in the eighteenth century; etwelcher, OHG. ëte. wëlih, now practically obs.; ganz, OHG. and MHG. ganz, unhurt, whole, sound; gesamt, MHG. gesament, pp. of samenen, to collect, gather; irgend einer, where irgend = MHG. iergen, OHG. io wergin ; jeder, in the eighteenth century also ieder, MHG. ieder, iewëder, 
OHG. iogiwëdar, each of both, but in late MHG. it came to mean each of any number; at a later period -er was regarded as an adjectival ending, whence the NHG. inflected forms jeder, jede, jedes, \&c. ; jedermann, formerly written as two words with both elements inflected, as dat. jederm manne; jedermänniglich, nearly obs., a contamination of jedermann and männiglich; jedweder, obs. except in poetry, MHG. iedewëder, each of two; jeglicher, now only used in ceremonial language, MHG. iegelïcher, each, where gelich = NHG. gleich; jemand, generally with acc. and dat. like the nom., the older dat. was jemande; since the eighteenth century also occur dat. jemandem, acc. jemanden with adjectival endings (similarly niemand), OHG. gen. eomannes, dat. eomanne, acc. eomannan; kein from older nechein, OHG. nichein, not even one: ne came to be felt as a negative particle, and was then omitted, whence kein; lauter, MHG. lūter, bright, clear, transparent; manch, mancher, MHG. manec, inflected form maneger; männiglich, which became obs. in the seventeenth century, has been restored again in pseudoarchaic style; OHG. manno gilih, each man, lit. each of men; mehrere, formed from mehr with double comparative suffix ; sämtlich, formed from samt $=$ M HG. samet, related to samenen, see gesamt; viele pl. of viel = MHG. vil ; welch, welcher, OHG. hwëlīh; wenig (pl. wenige), MHG. wēnec, inflected form wēneger; wer, OHG. hwër.

$\$ 470$. etwas, MHG. ëtewaz, the neut. to MHG. ëtewër, any one; man, although man was used as an indef. pronoun in OHG. and MHG., its use differed from NHG. in so much as it could still take the def. or indef. article before it; nichts, still written nichtes until the beginning of the eighteenth century, is an old gen. which has been preserved in NHG. in nichtswïrdig, nichtsdestoweniger; the use of nichts as nom. acc. arose in the fourteenth century from the combination nihtesniht $=$ nichts von nichts, through 
niht being regarded as a negative particle, whereas it was really a noun: OHG. neowiht, niowiht, later niewiht, nieht, lit. never a being or thing, gen. neowihtes, dat. neowihte. In late OHG. nieht came to be used as a simple negative, with the meaning not.

\section{CHAPTER XVII}

\section{VERBS}

\$471. In the parent Indg. language the verbs were divided into two great classes: athematic and thematic. In the athematic verbs the personal endings were added to the bare root which had the strong grade form of ablaut in the singular, but the weak grade in the dual and plural. Thus for example the singular and plural of the verbs for 'to be' and 'to go' were: *és-mi, *és-si, *és-ti, *s-més or *s-mós, *s-té, *s-énti ; *éi-mi, *éi-si, *éi-ti,

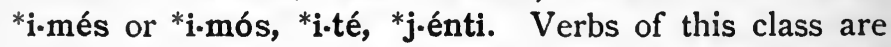
often called mi-verbs because the first person singular ends in -mi. The Germanic languages have only preserved a few traces of the mi-conjugation (\$ 541). Nearly all the verbal forms, which originally belonged to this class, passed over into the ó-conjugation in the prim. Germanic period.

In the thematic verbs the stem vowel, which could be either of the strong or weak grade of ablaut, remained unchanged throughout the present; in the former case they are called imperfect presents (as OHG. biotan, nëman, ëzzan, \&c.), and in the latter case aorist presents (as OHG. sūfan, backan, \&c.). The present was formed by means of the thematic vowels, e, 0 , which came between the root and the personal endings, thus the present singular and plural of the verb for 'to take' was *némō 
(from *ném·0.a), *ném·e-si, *ném·e-ti, *ném·o-mes, (-mos), *ném·e.te, *ném-o.nti. Verbs of this class are generally called $\overline{0} \cdot$ verbs because the first person singular ends in -0. The old distinction between the mi- and the o.conjugation was fairly well preserved in Greek, as cimi, I am,

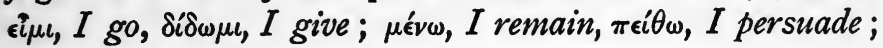
$\tau \rho^{t} \beta \omega$, I rub, $\tau^{t} \phi \omega$, I smoke.

$\$ \mathbf{4 7 2}$. In treating the history of the verbal forms in German it is advisable to start out partly from prim. Germanic and partly from the oldest OHG. The Indg. verbal system underwent so many radical changes in prim. Germanic that it would be necessary to treat here in detail the verbal system of the non-Germanic languages such as Sanskrit, Greek, and Latin in order to account for all the changes.

In the Germanic languages the verbs are divided into two great classes:-Strong and Weak. The strong verbs form their preterite (originally perfect) and past participle by means of ablaut ( $\$ 185$ ). The weak verbs form their preterite by the addition of a syllable containing a dental (Goth. -da, (.ta), OHG. -ta), and their past participle by means of a dental suffix (Goth. $\cdot p,(-t), O H G . \cdot t)$.

Besides these two great classes of strong and weak verbs, there are a few others which will be treated under the general heading of Minor Groups.

The strong verbs were originally further sub-divided into reduplicated and non-reduplicated verbs, as Goth. haldan, to hold, lētan, to let, preterite haíhald, laílōt; niman, to take, hilpan, to help, preterite nam, halp. In OHG. the reduplication entirely disappeared in the prehistoric period of the language. The non-reduplicated verbs are divided into six classes according to the six ablaut-series ( $\$ 185)$. The originally reduplicated verbs are put together in this book and called Class VII.

\$ 473. The OHG. verb has the following independent 
forms:-one voice (active), two numbers, three persons, two tenses (present and preterite), two complete moods (indicative, and subjunctive, the latter originally the optative), besides an imperative which is only used in the present tense; three verbal nouns (present infinitive, present participle, and gerund), and one verbal adjective (the past participle).

\section{A. Strong Verbs.}

$\S$ 474. We are able to conjugate a strong verb in $\mathrm{OHG}$. when we know the four stems, as seen (I) in the infinitive or first pers. sing. pres. indicative, (2) first pers. sing. pret. indicative, (3) first pers. pl. pret. indicative, (4) the past participle. The pret. subjunctive and the second pers. pret. indicative have the same stem vowel as the pret. pl. indicative. The conjugation of nëman will serve as a model for all strong verbs.

\section{Present.}

Indicative.

\section{OHG.}

Sing. I. nimu

2. nimis, (-st)

3. nimit

Plur. I. nëmemēs, (·ēm, ·ēn)

2. nëmet

3. nëmant
MHG. nime nimest nimet

nëmen nëmet nëment
NHG. nehme nimmst nimmt nehmen nehm(e)t nehmen

Subjunctive.

Sing. I. nëme

2. nëmēs, (-st)

3. nëme

Plur. I. nëmēm, (·ēn, ·emēs)

2. nëmēt

3. nëmēn nëme nëmest nëme

nëmen nëmet nëmen nehme nehmest nehme nehmen nehmet nehmen 
Imperative.

OHG. MHG. NHG.

Sing. 2. nim nim nimm

Plur. I. nëmemēs, (-ēm, -ēn) nëmen

2. nëmet nëmet

Infinitive.

nëman

nëmen

Gerund.

Gen. nëmannes

nëmennes

Dat. nëmanne

nëmenne

Participle.

nëmanti

nëmende

nehmend

Preterite.

Indicative.

\section{OHG.}

Sing. I. nam

2. nāmi

3. nam

Plur. I. nāmum, (-un, -umēs)

2. nāmut

3. nāmun
MHG. nam næme nam

nāmen nāmet nāmen nehmen

nehm(e)t 


\section{The Endings of Strong Verbs.}

$\$ 475$. On the weakening of the endings in $M H G$. and NHG. see $\S \S 170-84$.

\$ 476. Pres. indic.: Indg. *nemō regularly became nimu in OHG. ( $\$ 62,162)$ and nime in MHG. (\$170). Indg. *nemesi would regularly have become *nimi ( $\$ 5 \mathbf{5 5}$, 211) in OHG. through the intermediate stages *nemiz(i), *nimiz. The retention of the $-\mathbf{s}$ may be partly due to those verbs which originally did not have the accent on the stem syllable (as the aorist presents), and partly to the pronoun, which was often attached enclitically to the verb. The ending -st arose partly from analogy with the preterite-present forms kanst, scalt, weist, \&c., and partly from a false etymological division of the pronoun from the verb to which it was often attached enclitically, thus nimisdu became nimistu, from which nimist was extracted as the verbal form, see $\S \mathbf{4 3 4}$, and cp. the similar process in $\mathrm{OE}$. The ending -st was at first confined to the pres. indic. and then at a later period it became extended to the pres. and pret. subjunctive. On the loss of the e in NHG. nimmst, nimmt, see $\S 181$. OHG. nimit is a regular development from Indg. *nemeti through the intermediate stages ${ }^{*}$ nemepi, ${ }^{*}$ nemiđ(i), *nimid (as in OS.). Indg. *nemomes would regularly have become *nëmam (=Goth. nimam), but the oldest $\mathrm{OHG}$. form is nëmamēs (nëmemēs), the $-\bar{e}$ s of which has not yet been satisfactorily explained. The ending -ès belonged originally to the pres. indicative only, but in OHG. it was often extended to the first pers. plural of the other tenses and moods. And in like manner the ending -ēm, (-ēn), which properly belonged to the pres. subjunctive only, was often extended to the imperative and pres. indicative. -en came to be the usual ending in late OHG., whence the MHG. and NHG. ending. The original form of the second pers. plural was *nemete, 
which would regularly have become *nimit in OHG. through the intermediate stages *nemepe, *nemiđ(i), *nimid. OHG. nëmet is a new formation which is not easy to account for. nëmant is regularly developed from the original form *nemonti through the intermediate stages *nemonji, *nemanđ, *nemand (= Goth. nimand). In late MHG. the first pers. pl. came to be used for the third person, whence the NHG. ending.

\$ 477. Pres. subj.: This tense is properly an old optative. The original forms of the singular and plural were: *nemoi-, *nemois, *nemoit, *nemoim., *nemoite, *nemoint. The final -t was regularly dropped in prim. Germanic (\$161) and the oi became ai during the same period ( $\$ 44)$. Then ai became $\overline{\mathbf{e}}$ in prehistoric $\mathrm{HG}_{\text {. and }}$ remained as $\overline{\mathrm{e}}$ when protected by a following consonant, but was shortened to e when final (\$\$ 162-3). OHG. nëmēs has $\cdot s$ from the pres. indicative, the regular form would be *nëme (\$ 211). The $\overline{\mathrm{e}}$ was shortened to $\mathrm{e}$ in MHG., whence NHG. nehmen, \&c.

\$ 478. Imperative: The original form of the second pers. singular was *neme, which would regularly have become *nimi in OHG. The final vowel disappeared in the prehistoric period of the language in all classes of strong verbs, as OHG. stīg, biut, bint (hilf), nim, gib, far, rāt. The final vowel regularly disappeared after long stems, and then, after the analogy of verbs with long stems, it was also dropped in those with short stems (\$162). In MHG. a final -e began to be added after the analogy of the weak verbs ( $(173)$, as stige, binde, nime, \&c. In NHG. the second pers. singular may end in e, except kommen, lassen, and those verbs which still preserve the old interchange between $i$ and $e$ in the present ( $\$ 181$ ), as steige, biete, binde, fahre, rate, but komm, lass, hilf, nimm, gib. The plural endings are the same as the indicative. The first pers. plural began to disappear in the ninth cen- 
tury, its place being taken by the pres. subjunctive, which at a later period became the general form.

\$ 479. Pret. indic.: The original forms of the singular were *noma, *nomtha, *nome, cp. Gr. oi $\delta$, oi $\sigma \theta a$, oi $\delta \epsilon_{\text {. The }}$ form *noma regularly became nam in OHG. (\$ 162). *nomtha would regularly have become *namt through the intermediate stages *nompa, *namđa, *namd. But in the West Germanic languages the old ending has only been preserved in the preterite-present verbs, as OHG. weist, scalt, maht, muost, \&c. (\$ 534). nāmi is properly an old aorist and corresponds to a prim. Germanic form *nǣmez which would have become *nām in OHG. (\$ई 70, 211). nāmi has its final i $i$ after the analogy of verbs with short stem, as stigi, buti, \&c. nāmi regularly became næme in MHG. (\$ 79). Already in the twelfth century næmes(t) with $\cdot \mathbf{s}(\mathbf{t})$ from the present began to appear beside næme, and then at a later period næmest was made into nāmest with $\overline{\mathbf{a}}$ from the plural, whence NHG. nahmst. The form with the ending -e disappeared in the fifteenth century. The original third pers. sing. *nome would normally have become *nami in OHG. nam is a new formation after the analogy of verbs with long stems, as bant, half, \&c. It is difficult to say what the plural forms were in the parent language. Only so much is certain that the third pers. plural ended in $n$ t (with vocalic $\mathbf{n}$ ) which regularly became $u$ un in prim. Germanic ( $\$ \$ 49,161)$, the $\mathfrak{u}$ was then levelled out into the first and second persons. The $t$ in namut is from the present. The $\mathbf{u}$ in the plural was weakened to e in MHG., whence the NHG. endings.

$\$ 480$. Pret. subj. : The original endings were singular : -jēm, -jēs, -jēt, plural : -ìm, -ite, -int, consisting of the optative element $\cdot j \bar{e} \cdot,(\cdot \bar{i} \cdot)$ and the personal endings. Already in prim. Germanic the $\bar{i}$ of the plural was levelled out into the singular. The $\overline{1}$ remained when protected by a following consonant, and was shortened to $i$ when final (\$\$162-3). 
OHG. nāmi for *nām after the analogy of verbs with short stems, as stigi, buti, \&c. ( $\$ 162)$. The i, i were weakened to e in MHG., whence the NHG. endings.

\section{General Remarks on the Strong Verbs.}

$\S$ 481. The interchange of consonants due to Verner's law ( $\$ 221$ ) began to be given up already in OHG. by levelling out one or other of the consonants. This process of levelling has been almost completely carried out in NHG. The following verbs amongst others have levelled out the consonant of the present and of the pret. first and third pers. singular: finden, meiden, werden, genesen, lesen, gedeihen, leihen, sehen, verzeihen; and the following have levelled out the consonant of the pret. plural and past participle : frieren, verlieren, war, schlagen, heben.

$\$ 482$. A certain number of originally strong and weak verbs have regularly fallen together in the present in NHG., as bleichen (MHG. blichen and bleichen), schleifen (MHG. slifen and sleifen), schweigen (MHG. swigen and sweigen), weichen (MHG. wichen and weichen), pflegen (MHG. pflëgen and pflegen), schmelzen (MHG. smëlzen and smelzen), schwellen (MHG. swëllen and swellen), verderben (MHG. verdërben and verderben), löschen ( $M$ HG. lëschen and leschen), wiegen ( $M H G$. wëgen and wegen), laden (OHG. ladan and ladōn).

$\$ 483$. Present indic.: In the pres. sing. of Class II the stem vowel of the plural has been levelled out into the singular in NHG., as biete, bietest, bietet, pl. bieten, MHG. biute, biutest, biutet, pl. bieten. In the verbs of Class III containing $e$ in the infinitive, and of Classes IV and V, the first pers. sing. has been remodelled in NHG. on analogy with the inf. and the plural, as helfe, nehme, gebe, but MHG. hilfe, nime, gibe. The old interchange between $e$ in the plural and $\mathbf{i}(\$ \mathbf{5 5}, \mathbf{2})$ in the second and third pers. 
sing. has generally been preserved in NHG., as hilft, nimmt, gibt, stiehlt, liest, MHG. hilfet, nimet, gibet, stilt, liset. Whether the $\mathbf{i}$ in Classes IV and V has remained short or has been lengthened to $\overline{\text { (written }} \mathrm{ie}$ ) depends upon the following consonant ( $\$ 105)$. In a few verbs the old interchange between $\mathrm{e}$ and $\mathbf{i}$ has been given up, as bewegt, genest, melkt, pflegt, webt; wiegen. When the stem ended in a dental, syncope of the $e$ and loss of the final $t$ in the third pers. sing. began to take place already in MHG. and has been carried to a great extent in NHG., as gilt (MHG. gilt beside giltet), rät (MHG. ræt beside rætet), wird (late OHG., MHG. wirt beside wirdet; contraction has also taken place in the second pers. sing. wirst), and similarly in birst beside berstet, brät, ficht, flicht, hält, lädt, schilt, tritt.

\$ 484. Preterite indic.: In NHG. the vowel of the pret. plural has been levelled out into the singular in verbs belong. ing to Class I, as schrieb, schrieben; stritt, stritten, MHG. schreip, schriben; streit, striten. In Class II the pret. is for the most part a new formation with o from the past participle, as bog, bogen, gebogen, MHG. bouc, bugen, gebogen; sott, sotten, gesotten, MHG. sōt, suten, gesoten. In Class III the vowel of the singular has been levelled out into the plural, as band, banden, MHG. bant, bunden; half, halfen, MHG. half, hulfen. The old distinction has been preserved in ward, wurden. In Classes IV and V the vowel of the plural has been levelled out into the singular, as nahm, nahmen, stahl, stahlen, MHG. nam, nāmen, stal, stālen; gab, gaben, mass, massen, MHG. gap, gāben, maz, māzen.

The second pers. singular is an old augmentless aorist like Greek $\lambda i \pi \epsilon s$ (Homeric) beside ordinary classical Greek ¿ $\lambda$ เा of Classes I and II where the stem syllable was short, as stigi, buti, \&c. In Classes III-VII, bunti, nāmi, gābi, fuori, slāfi, the $i(\S 162,2)$ was due to the analogy of Classes 
I and II. In MHG. the above forms regularly became stige, büte, bünde, næme, gæbe, vuiere, slæfe. In NHG. the second pers. singular is a new formation from the other forms of the preterite, as stiegst, botest, bandest, \&c.

The pret. indic. is morphologically an old perfect, which already in the oldest period of the German language was chiefly used to express the past tense. The perfect and pluperfect were generally expressed in OHG. by the past participle and one of the auxiliary verbs habēn, eigan, to have, and wësan, to be, as ër habēt uns gizeigōt, he has shown us; thaz eigut ir gihōrit, that have ye heard; ër ist quoman, he has come; ër habēta funtan, he had found. These tenses were generally expressed in MHG. by the past participle and hān, a contracted form of haben, or $\sin =$ NHG. sein.

\$ 435. Preterite subj.: The preterite subjunctive is originally an optative. In OHG., as in the other Germanic languages, it had the same stem form as the pret. pl. indica. tive. The first pers. sing. of the seven classes of strong verbs was stigi, buti, bunti (hulfi), nāmi, gābi, fuori, riati (liofi). These forms regularly became in $\mathrm{MHG}$. stige, büte, bünde (hülfe), næme, gæbe, viiere, riete (liefe).

In classes I and VII the NHG. forms are normally developed from the corresponding MHG. forms, as stiege, bliebe, miede, schriebe, bisse, griffe, litte, schnitte, stritte, \&c.; riete, fiele, ginge, hielte, schliefe, liefe, riefe, stiesse, \&c. In class II the pret. subj., which would regularly have had $\ddot{u}$, has been remodelled on analogy with the $O$ in the pret. indic., as böge, böte, flöge, flösse, schöbe, \&c. In class III the pret. subj. would regularly have $\ddot{i}$. This $\ddot{i}$ has generally remained in verbs containing $\mathbf{r}+$ consonant, and in a few others, as stürbe, verdürbe, würbe, wïrde, würfe, but bärge, bärste beside börste; hiulfe, schünde beside hälfe, schände. Those verbs in which the stem vowel of the pret. sing. indic. has been levelled out into the plural 
generally have ä, as bände, fände, schwände, wände, dränge, gelänge, sänge, sänke, tränke, zwänge, \&c., but beföhle, empföhle, gölte, and schölte beside schälte. Those verbs which have a double nasal generally have ö, or ö beside ä, as begönne, glömme, klömme, spönne; gewönne, rönne, sönne, schwömme, beside gewänne, ränne, sänne, schwämme. Those verbs which have $o$ in the pret. indic. after the analogy of the past participle have ö in the pret. subj., as föchte, flöchte, quölle, mölke, schwölle, schmölze, \&c. Classes IV and V regularly have ä from MHG. $æ$, as nähme, bräche, gebäre, käme, spräche, \&c., but stöhle beside stähle; ässe, bäte, läge, läse, sähe, träte, \&c. But those verbs which have 0 in the pret. indic., chiefly after the analogy of the past participle, have ö, as schöre, schwöre (inf. schwären); pflöge, wöge, wöbe. Verbs of class VI regularly have $\mathfrak{u}$ from MHG. üe, as führe, grübe, schlïge, schwïre, trïge, wilsche, \&c., but höbe, stände beside hïbe, stïnde because of the pret. indic. hob, stand.

§486. Infinitive and Gerund: The infinitive was originally a nomen actionis, formed by means of various suffixes in the different Indg. languages. The suffix -ono., to which was added the nom. and acc. neuter ending $\cdot \mathrm{m}$, became generalized in prim. Germanic, thus the original form was *nemonom, which regularly became nëman in OHG. through the intermediate stages *nemonon, *nemana. In prim. West Germanic the infinitive took a genitive and dative ending like an ordinary noun of the ja. declension (\$363), whence OHG. nëmannes, nëmanne, MHG. nëmennes, nëmenne ( $\S 213$ ). The MHG. dat. ze nëmenne, lësenne, \&c. has become nehmend-, lesendin NHG. See Syntax.

\$ 487. Pres. Participle: In the parent language the stem of the pres. participle ended in -nt, as in Gr. фípovr-, Lat. ferent-. The -nt regularly became -nt in OHG.

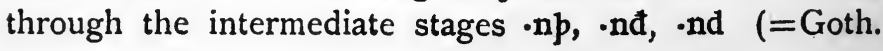


nimands). The masculine and neuter were originally declined like consonant stems (\$397). The nom. of the feminine ended in $\cdot \overline{1}$, which was shortened to $\cdot \mathbf{i}$ in prehistoric HG. (\$162). The masculine and neuter became ja.stems in prehistoric OHG., and thus fell together with the nominative of the old feminine form, nëmanti, gëbanti, \&c. The pres. participle was declined in OHG. like an ordinary adjective ( $\$ \$ 401,404)$, whence the MHG. and NHG. inflexions.

\$ 488. Past Participle: The past participle was formed in various ways in the parent language. In the prim. Germanic period the suffix •éno., -óno- became restricted to strong verbs, and the suffix -to- to weak verbs. In the strong verbs $\mathrm{OE}$. and O.Icel. generalized the form •éno-, and Gothic and OHG. the form róno., thus *numonos regularly became numans in Goth. and gi-noman in OHG.

In OHG. perfective verbs like bringan, findan, quëman, wërdan did not have the prefix gi- in the past participle, nor did verbs containing an unaccented prefix correspond. ing to NHG. be., ent., er., ge., ver., zer., \&c. All other verbs generally had gi. in OHG. and ge. in MHG. In NHG. the principle has been generalized that all simple verbs with the accent on the first syllable take ge;, as gestiegen, geboten, gekommen, gefunden, genommen, gebracht, \&c., but worden (auxiliary) beside geworden; whence weak verbs ending in -ieren (marschieren, \&c.) do not now have ge-, although they had it in MHG. And in like manner verbs with an inseparable prefix do not have it, as erfunden, entnommen, verstanden, \&c., but when the original prefix is no longer felt as such the verb takes ge-, as geblieben (MHG. be-liben), gefressen (Goth. fra-itan). A few verbs such as missbilligen, missbrauchen, misshandeln, willfahren, $\& c$., have or have not ge-in the past participle according as the first syllable is accented or unaccented.

$\$ 489$. The history of the future, perfect and pluperfect 
tenses, of the 'conditional' (ich wirde nehmen), and of the formation of the passive voice, will be treated in the syntax.

The Classification of the Strong Verbs.

\section{Class I.}

$\S 490$. The verbs of this class belong to the first ablaut. series and therefore had in OHG. $\overline{1}$ in all forms of the present, ei or $\overline{\mathrm{e}}$ in the first and third persons of the preterite singular ( $(\mathbf{7 5})$, and $\mathbf{i}$ in the preterite plural and past participle, thus :

$\begin{array}{lllll}\text { OHG. } & \overline{1} & \text { ei, }(\overline{\mathbf{e}}) & \mathbf{i} & \mathbf{i} \\ \text { MHG. } & \overline{\mathbf{i}} & \text { ei, }(\overline{\mathrm{e}}) & \mathbf{i} & \mathbf{i} \\ \text { NHG. } & \text { ei } & \text { ie, (i) } & \text { ie, (i) } & \text { ie, (i) }\end{array}$

In passing from MHG. to NHG. i regularly became ei (\$125), and would therefore have fallen together with the ei in the pret. singular, but in NHG. the vowel of the pret. plural has been levelled out into the singular so as to keep the present and preterite distinct. The MHG. $\mathbf{i}$ has been regularly lengthened to ie before NHG. medial voiced consonants, but has remained short before medial voiceless consonants $(\$ 105)$. This process of levelling began already in the MHG. period and became more frequent in the fifteenth century. The old distinction between the singular and plural was still for the most part preserved in Luther's works, but in the seventeenth century the process of levelling had been completely carried out.

OHG. scriban MHG. schriben NHG. schreiben screib scribum

schreip schriben

schrieb schrieben giscriban geschriben geschrieben

Similarly bleiben (MHG. beliben), reiben, scheinen, steigen, 
treiben. In meiden the $\mathrm{d}$ of the present has been extended to all forms of the verb, cp. MHG. miden, meit, miten (§ 221), gemiten. In verweisen (MHG. verwizen) the 3 has become voiced ( $\$$ 264). The following verbs were originally weak, but began to have strong forms beside the weak already in MHG.: preisen (MHG. prisen), schweigen (MHG. swigen, OHG. swigēn; OHG. and MHG. sweigen, the causative verb to OHG. *swigan), weisen (OHG. and MHG. wisen), beweisen.

The following verbs have become weak in NHG.: greinen (MHG. grinen) ; neiden (MHG. nīden, neit, niten, geniten), chiefly poetical, in the colloquial language it has been supplanted by beneiden; neigen (MHG. nigen); reihen (MHG. rïhen).

$\begin{array}{lllll}\text { \$491. OHG. dỉhan } & \text { dēh } & \text { digum } & \text { gidigan } \\ \text { MHG. dīhen } & \text { dēch } & \text { digen } & \text { gedigen } \\ \text { NHG. gedeihen } & \text { gedieh } & \text { gediehen } & \text { gediehen }\end{array}$

The old past participle has been preserved in the adj. gediegen. In NHG. the $\mathbf{h}$ of the present has been extended to all forms of the verb, and the pret. and past participle have been formed after the analogy of verbs like schreiben; similarly in verzeihen (M HG. zīhen, zēch, zigen, gezigen); leihen (OHG. līhan, lēh, liwum ( $\S 221$ ), giliwan beside the new formation gilihan; MHG. lihen, lēch, lihen, gelihen); schreien (MHG. schrien, schrei, (schrē), schrirn, geschrirn; the second $\mathbf{r}$ in the pret. plural and pp. has never been satisfactorily explained), schrie, geschrieen are new formations. speien (OHG. spiwan, spēo, (spē), spiwum, gispiwan, MHG. spì(w)en, spē, (spei), spiwen, gespiwen), the NHG. pret. and past participle are new formations after the analogy of verbs like schreiben; formerly also weak forms speite, gespeit were in use. seihen (MHG. sīhen, (sigen), seic, sigen, gesigen) has become weak. 
§492. OHG. stritan streit stritum gistritan MHG. striten streit striten gestriten NHG. streiten stritt stritten gestritten

Similarly gleiten, reiten, schreiten; erbleichen, schleichen, streichen, weichen; greifen, pfeifen, schleifen; sich befleissen (MHG. vlizen), beissen, reissen, schleissen, schmeissen; leiden (MHG. lïden, leit, liten, geliten), schneiden (MHG. snïen, sneit, sniten, gesniten).

The following strong verbs have, or formerly had, weak preterites and past participles beside the strong : bleichen, gleissen, gleiten, kneifen, spleissen. gleichen (MHG. gelichen) was weak in MHG. and remained so until the seventeenth century.

\section{Class II.}

\$ 493. The verbs of this class belong to the second ablaut-series and therefore had in OHG. io (\$186) in the infinitive and the plural of the present indicative, iu in the pres. singular ( $\$ 77)$, ou or $\bar{o}$ in the first and third pers. of the pret. singular ( $\$ 76), \mathfrak{u}$ in the pret. plural, and $o$ in the past participle, thus :

\begin{tabular}{|c|c|c|}
\hline HG. & iu & ou, $(\overline{\mathbf{o}})$ \\
\hline HG. ie & iu & ou, $(\overline{0})$ \\
\hline NHG. ie & ie & ŏ \\
\hline
\end{tabular}

In NHG. the ie of the pres. singular is due to levelling out the stem vowel of the plural. The normal development of MHG. iu is eu in NHG., which regularly occurs in the verbs of this class in Luther (fleugt, fleucht (inf. fliehen), kreucht, reucht (inf. riechen), zeucht, \&c.), and is also often found in the literature of the seventeenth and eighteenth centuries. The Modern German preterite is a new formation with o from the past participle, formed in the same manner as Modern English chose, froze from chosen, frozen. But already in the $\mathrm{MHG}$. period the 
pret. plural was often written with 0 in Middle German, because in this dialect $\mathbf{u}$ and $\boldsymbol{o}$ closely resembled each other in sound. This may also have been a factor in bringing about the form of the NHG. preterite through the vowel of the plural being levelled out into the singular. This process of levelling began in late MHG., became more frequent in the fifteenth century, and was practically complete by the beginning of the seventeenth century. In Modern German the $o$ is long when followed by a medial voiced consonant, and generally short when followed by a medial voiceless consonant.

OHG. biogan biugu boug bugum gibogan MHG. biegen biuge bouc bugen gebogen

NHG. biegen biege bog bogen gebogen

Similarly fliegen, klieben, kriechen, riechen, schieben, stieben. triefen has weak preterite and past participle beside the strong. ligen (MHG. liegen, liuge, liugest, liuget, pl. liegen) was formed from the noun ligge about the middle of the seventeenth century. The old forms leugst, leugt often occur down to the eighteenth century. trïgen (betrügen) is a late Modern German new formation from association with liggen and the noun trug. triegen was still the usual form in the eighteenth century. The following verbs have become weak: schmiegen, blänen with äu from association with blau in blau schlagen (MHG. bliuwen, bliuwe, blou, blūwen, geblūwen), reuen (MHG. riuwen), branen (MHG. briuwen beside brūwen with $\overline{\mathrm{u}}$ from Middle German, §126), kauen, rarely käuen, cp. wiederkäuen (MHG. kiuwen beside küwen).

\$ 494. Here belong also the old aorist presents with weak grade vowel in all forms of the present.

$\begin{array}{lllll}\text { OHG. } & \text { sūfan } & \text { souf } & \text { suffum } & \text { gisoffan } \\ \text { MHG. } & \text { sūfen } & \text { souf } & \text { suffen } & \text { gesoffen } \\ \text { NHG. } & \text { saufen } & \text { soff } & \text { soffen } & \text { gesoffen }\end{array}$


Saugen (MHG. sūgen) has weak preterite and past participle beside the strong; similarly schrauben (late MHG. schrüben), properly a weak verb, but also in MHG. with strong and weak preterite and past participle, the pp. (verschroben) is always strong; schnauben (MHG. snūben, generally weak, but also sometimes strong).

\$495. OHG. biotan biutu bōt butum gibotan MHG. bieten biute bōt buten geboten NHG. bieten biete bot boten geboten

Similarly, but with short 0 in the preterite and past participle: fliessen (MHG. vliezen), giessen, geniessen, schiessen, schliessen, spriessen, verdriessen. ziehen (MHG. ziehen, zōch, zugen, gezogen, § 221), fliehen (MHG. vliehen, vlōch, vluhen (OHG. fluhum), gevlohen (OHG. giflohan)) with $\mathbf{h}$ for $\mathbf{g}$ in the pret. plural and past participle from the present. sieden (MHG. sieden, sōt, suten, gesoten) has strong and weak preterite and past participle. frieren (MHG. vriesen, vrōs, vrurn, gevrorn, § 221) has its second $\mathbf{r}$ from the pret. plural and past participle, and similarly in verlieren (MHG. verliesen). kiesen (MHG. kiesen, kōs, kurn, gekorn). niesen (MHG. niesen) has become weak.

\section{Class III.}

$\S$ 496. The verbs of this class belong to the third ablautseries, and include the strong verbs having a medial nasal or liquid + consonant, and a few others in which the vowel is followed by two consonants other than nasal or liquid + consonant.

Verbs with nasal + consonant had in OHG. $\mathbf{i}$ in the infinitive and throughout the present $(\$ 55)$, and $\mathbf{u}$ in the past participle $(\$ 57)$; the others had $\mathbf{i}$ in the pres. singular $(\$ \S 55,62), \ddot{e}$ in the infinitive and pres. plural, and o in the 
past participle. All verbs of this class had a in the pret. singular and $\mathbf{u}$ in the pret. plural.

$\begin{array}{llllll}\text { OHG. } & \text { i, (ë) } & \mathbf{i} & \mathbf{a} & \mathbf{u} & \mathbf{u},(0) \\ \text { MHG. } & \mathbf{i},(e \ddot{)}) & \mathbf{i} & \mathbf{a} & \mathbf{u} & \mathbf{u},(0) \\ \text { NHG. } & \mathbf{i},(\mathrm{e}) & \mathbf{i},(\mathrm{e}) & \mathbf{a} & \mathbf{a} & \mathbf{u},(0)\end{array}$

Verbs with nasal + consonant still have $\mathbf{i}$ in NHG. in all forms of the present. The other strong verbs belonging to this class have preserved the $\mathbf{i}$ in the second and third pers. singular of the present, but the first pers. singular has e after the analogy of the other forms of the present. The $\mathbf{i}$ ( $i c h$ hilfe) was still common in the sixteenth century, but e became more frequent in the seventeenth century, and in the eighteenth century it became the rule as in German of the present day.

Levelling began to take place in the preterite in late MHG. and early NHG. Sometimes the vowel of the singular was taken into the plural and vice versa. The distinction between the vowel of the singular and plural (band, bunden) is fairly general in Luther's works. Levelling out in both directions was common down to the eighteenth century: band, banden; bund, bunden. In late NHG. the vowel of the singular has, with one or two exceptions, been generalized.

In NHG. the $\mathbf{u}$ has become 0 in the past participle of verbs containing two nasals ( $\$$ 97).

$\begin{array}{lllll}\text { OHG. } & \text { bintan } & \text { bant } & \text { buntum } & \text { gibuntan } \\ \text { MHG. } & \text { binden } & \text { bant } & \text { bunden } & \text { gebunden } \\ \text { NHG. } & \text { binden } & \text { band } & \text { banden } & \text { gebunden }\end{array}$

Similarly dringen, gelingen, klingen, ringen, schinden (pret. also schund with levelling out of the old plural), schlingen, schwinden, schwingen, sinken, springen, stinken, trinken, winden, zwingen. The past participle of finden did not have the prefix ge. in OHG. and MHG. (funtan, 
vunden). The pret. and past participle of bringen were generally weak in OHG. (brāhta, gibrāht). bedingen and dingen, which were originally weak, have strong pret. and past participle beside the weak. hinken has become weak.

§497. rinnen (past participle NHG. geronnen, MHG. gerunnen, OHG. girunnan), and similarly entrinnen, sinnen, schwimmen, spinnen, gewinnen. glimmen, pret. glomm with o from the past participle, has weak pret. and past participle beside the strong, and similarly klimmen. beginnen (pret. OHG. bigan beside bigonda, MHG. began beside begunde) and besinnen, which formerly fluctuated between strong and weak forms, have now strong forms only. grimmen (ergrimmen) has become weak.

§498. OHG. hëlfan hilfu half hulfum giholfan MHG. hëlfen hilfe half hulfen geholfen NHG. helfen helfe half halfen geholfen

Similarly bergen, gelten, schelten, sterben, verderben, werben, werfen. The two last verbs were evolved out of one verb already in OHG. by levelling out in different directions. The regular forms were wërfan, wirfu, warf, wurbum, giworban ( $\$ \mathbf{2 2 1})$. werfen is due to the levelling out of the $\mathbf{f}$ and werben to the levelling out of the $b$, and then at a later period they became differentiated in meaning. werden (OHG. wërdan, wirdu, ward, wurtum, wortan late OHG. worden) has levelled out the forms with $\mathrm{d}$, and now takes the prefix ge- in the past participle when used as a principal verb. It is the only verb which has preserved the old distinction between the preterite singular and plural. The pret. singular form wurde has the ending of a weak verb.

§ 498. befehlen (OHG. bifëlhan, bifilhu, bifalh, biful. hum, bifolhan with $h$ in the pret. plural and past participle by levelling, § 221). The $\mathbf{h}$ disappeared after the 1 at an 
early period ( $\$ 283)$. This loss of $\mathbf{h}$ caused the stem vowel to be in an open syllable, which accounts for the long vowel in all forms of the verb (\$108), and similarly empfehlen.

§500. quellen, pret. quoll (MHG. qual, quullen, OHG. qual, quullum) with 0 from the past participle, and similarly melken (with strong and weak pret. and past participle), schmelzen, schwellen. bellen is now weak, but it formerly had a strong preterite boll, and past participle gebollen. The old strong verb schellen has been replaced by the denominative weak verb schallen, but beside schallte, geschallt, we also have the old strong forms (er)scholl, (er)schollen, verschollen.

\$501. verwirren (MHG. verwërren) with $i$ from the present singular has become weak, but the old past participle has been preserved in the isolated form verworren. gellen (MHG. gëllen), schmerzen (MHG. smërzen), schwelgen (MHG. swëlhen, swëlgen with $\mathrm{g}$ from the pret. pl. and past participle) have become weak.

$\S 502$.

brëstan

drëskan

fëhtan

fiëhtan

irlëskan irlisku
OHG. bristu drisku fintu flihtu irlisku brast

brustum

drask druskum gidroskan

faht fuhtum

flaht

fluhtum

irlask gifohtan

giflohtan

irloskan

MHG.

$\begin{array}{lllll}\text { brësten } & \text { briste } & \text { brast } & \text { brāsten } & \text { gebrosten } \\ \text { drëschen } & \text { drische } & \text { drasch } & \text { drāschen } & \text { gedroschen } \\ \text { vëhten } & \text { vihte } & \text { vaht } & \text { vāhten } & \text { gevohten } \\ \text { vlëhten } & \text { vlihte } & \text { vlaht } & \text { vlāhten } & \text { gevlohten } \\ \text { erlëschen } & \text { erlische } & \text { erlasch } & \text { erlāschen } & \text { erloschen }\end{array}$




\section{NHG.}

\begin{tabular}{|c|c|c|c|c|}
\hline bersten & $\begin{array}{l}\text { berste } \\
\text { dresche }\end{array}$ & 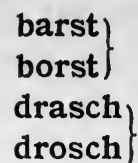 & $\left.\begin{array}{l}\text { barsten } \\
\text { borsten }\end{array}\right\}$ & $\begin{array}{l}\text { geborsten } \\
\text { gedroschen }\end{array}$ \\
\hline 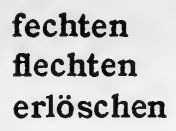 & $\begin{array}{l}\text { flechte } \\
\text { erlösche }\end{array}$ & $\begin{array}{l}\text { focht } \\
\text { flocht } \\
\text { erlosch }\end{array}$ & $\begin{array}{l}\text { fochten } \\
\text { flochten } \\
\text { erloschen }\end{array}$ & $\begin{array}{l}\text { gefochten } \\
\text { geflochten } \\
\text { erloschen }\end{array}$ \\
\hline
\end{tabular}

The only difference between the OHG. forms of the above verbs and those of class IV is the vowel of the pret. plural. In MHG., and also partly in OHG., the pret. plural was remodelled on the analogy of verbs of class IV. The $o$ in the preterite of the NHG. forms is from the past participle. On the ö in erlöschen, cp. $\$ \mathbf{8 2}$. The $\mathbf{r}$ in bersten has undergone metathesis.

\section{Class IV.}

\$503. The verbs of this class belong to the fourth ablaut-series, which includes the strong verbs whose stems end in a single liquid or nasal, and a few others. They had in OHG. $\ddot{e}$ in the infinitive and present plural, $\mathbf{i}$ in the pres. singular, $a$ in the pret. first and third pers. singular, $\overline{\mathbf{a}}$ in the pret. plural, and $\mathrm{o}$ in the past participle.

\begin{tabular}{|c|c|c|c|}
\hline OHG. & $\mathbf{i}$ & $\mathbf{a}$ & $\overline{\mathbf{a}}$ \\
\hline MHG. & $\mathbf{i}$ & $\mathbf{a}$ & $\overline{\mathbf{a}}$ \\
\hline NHG. & ё, (ie, i) & $\overline{\mathbf{a}}$ & $\overline{\mathbf{a}}$ \\
\hline
\end{tabular}

The history of the pres. singular is similar to that of verbs of class III with $e$ in the infinitive. That is, in NHG. the first pers. singular has $\overline{\mathrm{e}}$ or e (stehle, breche) and the second and third pers. have ie or $\mathbf{i}$ (stiehlt, bricht). In passing from MHG. to NHG. the vowel of the pret. plural has been levelled out into the singular. 
OHG. stëlan stilu stal stālum gistolan MHG. stëln stil(e) stal stālen gestoln NHG. stehlen stehle stahl stahlen gestohlen

Similarly gebären, nehmen (nimmt, genommen, § 114), scheren (pret. schor), schwären (pret. schwor). The preterites schor and schwor have o from the past participle just as in Modern English bore, stole, tore.

\$ 504. brechen (MHG. brëchen, briche, brach, brāchen, gebrochen), and similarly schrecken, erschrecken, sprechen, stechen, treffen.

$\S 505$. In OHG. quëman, quimu, quam, quāmum, quoman (quëman), the combinations quë., qui. became ko., ku., whence late OHG. inf. and pp. komen, and pres. first pers. singular kumu. At a later period the $\mathbf{k}$ was extended to all forms of the verb: MHG. komen, kumu, kam (quam), kāmen (quāmen), komen, and NHG. kommen, komme (a new formation from kommen), kam, kamen, gekommen.

$\S 506$. rächen (MHG. rëchen) is now weak, but the old past participle gerochen is still sometimes used in poetical language. The old strong past participle of verhehlen (MHG. verhëln, OHG. firhëlan) has been preserved in the isolated form verhohlen. entbehren (MHG. en(t)bërn) and ziemen (MHG. zëmen) have become weak. ziemen has been formed from the singular ziemt (MHG. zimet) owing to the verb being mostly used in the third pers. singular. stecken is properly a weak verb, but it has a strong pret. stack beside the weak, and it formerly had the strong forms stickt, gestocken.

\section{Class V.}

\$507. The verbs of this class belong to the fifth ablaut-series. It includes the strong verbs which contain e in the past participle, and whose stems end in other 
consonants than those in classes III and IV. The only difference between classes IV and $V$ is that the past participle of the former has $o$ and of the latter e, thus :-

$\begin{array}{llllll}\text { OHG. } & \ddot{e} & \mathbf{i} & \mathbf{a} & \overline{\mathbf{a}} & \ddot{e} \\ \text { MHG. } & \ddot{\mathbf{e}} & \mathbf{i} & \mathbf{a} & \overline{\mathbf{a}} & \ddot{\mathbf{e}} \\ \text { NHG. } & \check{\mathbf{e}} & \overline{\mathrm{e}} \text {, (ie, i) } & \overline{\mathbf{a}} & \overline{\mathbf{a}} & \text { è }\end{array}$

The history of the present and preterite is the same as in class IV.

OHG. gëban gibu gab gābum gigëban MHG. gëben gibe gap gāben gegëben NHG. geben gebe gab gaben gegeben

Similarly sehen (OHG. sëhan), geschehen (OHG. giskë. han), treten. The $\mathbf{h}$ in sëhan, giskëhan was levelled out to the pret. plural and past participle already in OHG., cp. §221. The NHG. pret. sing. sah, geschah (MHG. sach, geschach) are new formations from the stem forms of the plural. lesen (OHG. lësan, lisu, las, lārum beside lāsum, gilëran beside gilësan, MHG. lāren beside lāsen, gelern (rare) beside gelësen) has levelled out the $\mathrm{s}$, and similarly in genesen, which has in addition become weak in the present (geneset, genest). war with levelling out the plural form waren; the past participle of this verb did not exist in OHG. MHG. gewësen $=$ NHG. gewesen is a new formation from the infinitive. jäten, also in form gäten (MHG. jëten), and kneten (MHG. knëten) have become weak.

$\S 508$.

OHG. wëgan wigu wag wāgum giwëgan MHG. wëgen wige wac wāgen gewëgen

NHG. $\left.\left.\begin{array}{l}\text { wägen } \\ \text { wiegen }\end{array}\right\} \begin{array}{l}\text { wäge } \\ \text { wiege }\end{array}\right\}$ wog wogen gewogen

The $\ddot{a}$ in wägen is due to association with the noun wage. wiegen is a new formation from the singular 
(MHG. wiget) owing to its being chiefly used in the third pers. singular, cp. ziemen ( $\$ 506)$. MHG. $\bar{a}$ became $\bar{o}$ in NHG. through the influence of the $w$ (\$118), and then the vowel of the plural was levelled out into the singular, as in the other verbs of this class, and at a later period it was extended to the past participle. The old past participle is still preserved in the isolated form verwegen. Similarly bewegen, erwägen, weben. pflegen went over into class IV (past participle gepflogen beside gepflëgen) already in MHG., whence NHG. preterite pflog (older pflag) with o from the past participle. gären (MHG. jësen, gise, jas, jāren, gejërn). In MHG. the $\mathbf{g}$ only occurred in forms with $\mathbf{i}$ (as gise, giset), in NHG. the $\mathbf{g}$ has been generalized, partly due to association with the noun gare (gäre). In like manner the $r$ of the preterite plural and past participle has been generalized. All the verbs in this paragraph have become weak in the present and have weak beside the strong forms in the preterite and past participle.

\section{$\S 509$.}

OHG. mëzzan miz̧u maz māzum gimëzzan MHG. mëzzen mizze maz māzen gemëzzen NHG. messen messe mass massen gemessen

Similarly essen (MHG. ëzzen, āz, āzen, gëzъen), past participle gegessen with double ge-, fressen (MHG. vrëzzen, vrāz, vrāzen, pp. vrëzzen), vergessen. essen and fressen had a long vowel in the pret. singular already in prim. Germanic. The long vowel arose from the contraction of the old reduplicated syllable e with the stem vowel, cp. Goth. fr.ēt, O.Icel. OS. āt, OE. ǣt, Lat. èdī.

\$510. To this class also belong bitten, liegen, sitzen, which originally had $\mathbf{j}$ in the present (\$213), and were inflected in the present like a weak verb of class I ( $\$ 527)$. bitten (OHG. bitten, bittu, bat, bātum, gibëtan). This verb is properly an aorist present and originally belonged 
to class $\mathrm{I}$, but it passed over into class $\mathrm{V}$ in the prim.

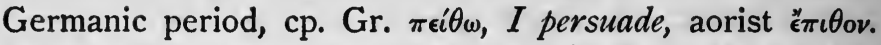
liegen (OHG. liggen, liggu, lag, lāgum, gilëgan) had single $\mathrm{g}$ in the present already in MHG. (ligen) after the analogy of the second and third pers. singular and of the other forms of the verb where single $\mathrm{g}$ was regular. sitzen (OHG. sitzen, sitzu, saz, sāzum, gisëzzan).

\section{Class VI.}

$\S 511$. The verbs of this class belong to the sixth ablautseries, and had in OHG. $a$ in the infinitive and past participle, and wo in the pret. sing. and plural. They had umlaut in the second and third pers. sing. of the present, as feris, ferit.

OHG. faran

MHG. varn

NHG. fahren

\section{fuor}

vuor

fuhr fuorum vuoren

fuhren gifaran

gevarn gefahren

Similarly graben, tragen, wachsen, waschen, the last two verbs with short a through being in a closed syllable. schlagen (OHG. slahan, sluoh (also sluog), sluogum, gislagan, $\S 221$ ) with $\mathrm{g}$ from the pret. plural and past participle. OHG. stantan, stuont (rarely stuot), stuontum (rarely stuotum), gistantan, MHG. standen (stēn, stān), stuont, stuonten, gestanden. Already in MHG. standen began to be supplanted by stēn $=$ NHG. stehen. The $\mathbf{n}$ belonged originally to the present only, $\mathrm{cp}$. English stand, stood, and verbs like Lat. frangō, frēgi. Early NHG. stund, stunden became stand, stunden after the analogy of early NHG. band, bunden ( $\$ 496)$, and then later stand, standen by levelling out the form of the singular. NHG. backen had two forms in the present in OHG.: bachu, I bake, with ch levelled out from the non-present forms, and backu $=$ prim. Germanic ${ }^{*}$ bakkō (Indg. 
*bhognō, § 202). In OHG. the ck only belonged to the present, whence bachan beside backan, buoh, buochum, gibachan, MHG. bachen beside backen, buoch, buochen, gebachen. In NHG. the ck has been taken into all forms of the verb, but the old preterite buch was still in use in early NHG. Beside the strong preterite we have now also the weak preterite backte. Two distinct OHG. verbs have fallen together in NHG. laden, viz. OHG. ladan, to load, and the weak verb ladon, to invite. The former began to have weak and the latter to have strong forms in MHG. In NHG. laden has strong beside weak forms in the present and preterite (lädst, lädt, lud beside ladest, ladet, ladete). mahlen, to grind, has become weak except in the past participle gemahlen. nagen, schaben (with old past participle preserved in the isolated form abgeschaben), waten have become weak. fragen was a weak verb in OHG. (frāgēn) and MHG. (vrāgen), but it now has strong beside weak forms in the present and preterite.

$\$ 512$. To this class also belong heben, schaffen, and schwören, which originally had $\mathbf{j}$ in the present and were inflected in the present like a weak verb of Class I ( $\$ 527)$. heben (OHG. heffen (Goth. hafjan), huob, huobum, -haban). The $\mathbf{b}$ belonged originally to the pret. plural and past participle only, but already in OHG. it was extended to the pret. singular and in MHG. to the present, whence MHG. heben, huop, huoben, gehaben. The NHG. preterite hob, past participle gehoben, for older hub, gehaben, have been remodelled on analogy with verbs like wob, gewoben ( $\$$ 508). The old past participle has been preserved in the isolated form erhaben. schaffen, to create (OHG. skepfen (Goth. ga.skapjan), skuof, skuofum, giskaffan). Already in OHG. a new infinitive skaffan was formed from the past participle, whence MHG. and NHG. schaffen. The NHG. weak verb schaffen, to do, work, is from the OHG. weak verb skaffōn. schöpfen 
(OHG. skepfen, MHG. schepfen) has become weak. schwören (OHG. swerien, swuor, swuorum, gisworan, with o from older a through the influence of the preceding w). The NHG. pret. schwor beside the regular form schwour has its o from the past participle.

\section{Class VII.}

$\S 513$. To this class belong those verbs which originally had reduplicated preterites, like Gothic haíhald, laílot, faíflōk, haíháit, inf. haldan, to hold, lētan, to let, flōkan, to complain, háitan, to call. This class of verbs is divided into two sub-divisions according as the preterite had ia (older $\bar{e}$, ea, $\S 71$ ) or io in OHG. ia and io fell together in ie in late OHG. ( $\$$ 71, 77). Much has been written about the stem vowel in the preterite of these verbs in OHG., but little or nothing is really known of how it came about. It is usually assumed to be due to the old reduplicated syllable having undergone contraction with the stem syllable, but this assumption leaves many phonological difficulties unexplained. The preterite sing. and plural have in all periods of the language the same stem vowel. Verbs, which in OHG. had a, $\overline{\mathbf{a}}$, or ei in the present, had ia in the preterite, and those which had ou, (o) $\S \mathbf{7 6}$, uo in the present had io in the preterite. With the exception of fāhan, hāhan, the past participle had the same stem vowel as the present.

$\begin{array}{llll}\text { § 514. OHG. haltan } & \text { hialt } & \text { gihaltan } \\ \text { MHG. halten } & \text { hielt } & \text { gehalten } \\ \text { NHG. halten } & \text { hielt } & \text { gehalten }\end{array}$

Similarly fallen. OHG. gangan, giang, gigangan : the present was supplanted by gēn (gān) (= NHG. gehen) in MHG. NHG. ging has been shortened from older gieng (§ 139). salzen has become weak except in the past parti- 
ciple gesalzen. falten and spalten have become weak in the present and preterite, but in the past participle they have strong beside weak forms: bannen (verbannen), schalten, spannen, umhalsen, walken, wallen, walten, and walzen have become weak.

$\begin{array}{llll}\text { § 515. OHG. } & \text { rātan } & \text { riat } & \text { girātan } \\ \text { MHG. } & \text { rāten } & \text { riet } & \text { gerāten } \\ \text { NHG. } & \text { raten } & \text { riet } & \text { geraten }\end{array}$

Similarly blasen, lassen ( $\$ 139$ ), schlafen. In NHG. braten has weak pres. and preterite beside the strong. OHG. fāhan (§ 54), fiang, gifangan, MHG. vāhen, vienc (pl. viengen), gevangen. In NHG. the inf. fangen is a new formation from the past participle; this took place in the Middle German dialect in the MHG. period. NHG. fing has been shortened from older fieng (\$139). Similarly hangen (OHG. hāhan, hiang, gihangan).

$\begin{array}{llll}\text { §516. OHG. heizan } & \text { hiaz } & \text { giheizan } \\ \text { MHG. heizen } & \text { hiez } & \text { geheizen } \\ \text { NHG. heissen } & \text { hiess } & \text { geheissen }\end{array}$

geschieden, the past participle of scheiden, is a new formation after the analogy of verbs like schreiben $(\$ 490)$; the old past participle has been preserved in the isolated form bescheiden. schweifen (OHG. sweifan) has become weak.

§ 517. stossen (OHG. stōzan, stioz, gistōzan, MHG. stōzen, stiez, gestōzen). "schroten (OHG. scrōtan, scriot, giscrōtan) has become weak, except that in the past participle strong and weak forms occur.

§ 518. laufen (OHG. loufan, liof, giloufan, MHG. loufen, lief, geloufen). hauen (OHG. houwan, hio, pl. hiowum, gihouwan, MHG. houwen, hie (hiu), pl. hiewen (hiuwen), gehouwen) had a weak preterite houte and past participle gehout beside the strong in MHG. In NHG, the present is weak, but was also strong 
in early NHG. (er heut), and the preterite has strong beside the weak form, hieb ( $\$ 237$ ), haute.

\$519. rufen (OHG. ruofan, riof, giruofan, $M H G$. ruofen, rief, geruofen) has become weak in the present. The preterite and past participle formerly fluctuated between strong and weak forms. The weak preterite rufte was common in the eighteenth century.

\section{B. Weak Verbs.}

§520. The weak verbs, which for the most part are derivative or denominative verbs, were in OHG. divided into three classes according as the infinitive ended in en (older -jan), $\cdot \bar{n}$, or e.en. Three stems are to be distinguished in the conjugation of a weak verb : the stem of the present, preterite, and past participle, which mostly agrees with that of the preterite.

NoTE.-Many points concerning the inflexion of weak verbs in the oldest periods of the Germanic languages have never been satisfactorily explained. For a summary and discussion of the various explanations, which have been suggested by scholars, the student should consult: Brugmann's Kurze vergleichende Grammatik der indogermanischen Sprachen; Streitberg's Urgermanische Grammatik; and Kluge's Vorgeschichte der altgermanischen Dialekte in Paul's Grundriss der germanischen Philologie, vol. I.

\section{Class I.}

\$521. In OHG. the verbs of this class are divided into two sub-divisions: $(a)$ verbs which originally had a short stem; (b) polysyllabic verbs and those which originally had a long stem syllable. Nearly all the verbs belonging to Class I are causative and denominative.

Sub-division $(a)$.

§522. Formation of the present stem: The present stem of these verbs became long (except in the second and 
third pers. sing. pres. indicative, and second pers. sing. imperative) by the West Germanic law of the doubling of consonants (\$213). The $\mathbf{j}$ had already disappeared in these persons before the operation of the law, for which reason they had single consonants in OHG. The verbs, however, ending in one of the affricatae $\mathbf{z z}(\mathbf{t z}), \mathbf{p f}$; and ck $(=$ West Germanic $\mathbf{t j}, \mathbf{p j}, \mathbf{k j})$, levelled out the affricatae and the ck to all forms of the present and to the second pers. sing. of the imperative in prehistoric $\mathrm{HG}$.

\$ 523. Formation of the pret. and past participle: The $\mathbf{j}$, which caused the doubling of the final consonants in the present stems, never existed in the preterite or past participle, so that these stems ended in single consonants. The preterite usually had the ending -ita, but verbs, whose present stems ended in one of the affricatae $\mathbf{p f}, \mathbf{z z}(\mathrm{tz})$, or ck ( = West Germanic pj, tj, $\mathbf{k j}$ ), had the ending -ta in the preterite. Those whose present stems ended in tt or 11 (=West Germanic dj, $1 \mathrm{j}$ ) sometimes had the one ending and sometimes the other.

The past participle had two forms, the one called the uninflected, the other the inflected form. The uninflected form ended in .it, and the inflected form ended in .itêr when the preterite ended in ita, and in tēer when the preterite ended in -ta.

\section{Sub-Division (b).}

\$ 524. In this sub-division the verbs underwent no consonant changes in the present. The preterite ended in th. The uninflected form of the past participle ended in -it and the inflected form in tēer.

\section{Class II.}

$\S 525$. This class originally contained verbs belonging partly to the athematic and partly to the thematic conjuga- 
tion ( $\$$ 471). The first pers. sing: of the former ended in -āmi and of the latter in -ājō. The $\bar{a}$ became $\bar{o}$ in the prim. Germanic period ( $\$ 37)$. In prehistoric OHG. the

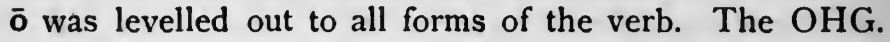
ending of the first pers. sing. of the pres. indicative is a remnant of the athematic or mi-conjugation.

\section{Class III.}

$\$$ 526. Most of the verbs belonging to this class were originally primary verbs like Latin habēre $=O H G$. habēn. The $\overline{\mathrm{e}}$ was levelled out to all forms of the verb in prehistoric OHG. It is doubtful whether the OHG. $\cdot \mathrm{m}$ of the first pers. sing. pres. indicative is a remnant of the miconjugation. It is more probable that the $\cdot \mathrm{m}$ is due to analogy of verbs of Class II.

$\S 527$. The full conjugation of leggen, hören, Class I, salbōn, Class II, and lëbēn, Class III, will serve as models for all weak verbs.

Present.

Indicative.

OHG.

Sing. I. leggu

2. $\operatorname{legis}(\mathrm{t})$

3. legit

Plur. I. leggemēs, hōremēs,
(-ēn)
2. legget
3. leggent
(-ēn)
hōret
hōrent

\section{MHG.}

Sing. I. lege

2. legest

3. leget

Plur. r. legen

2. leget

3. legent hōru

hōris(t) hōrit

hœre

hœrest

hœret

hœren

hœret

hœrent salbōm,(·ōn) lëbēm,(·ēn)

salbōs(t)

salbōt

salbōmēs,

(.ōn)

salbōt

salbōnt salbe

salbest

salbet

salben

salbet

salbent lëbēs(t)

lëbēt

lëbēmēs,

$$
\text { (-ēn) }
$$

lëbēt

lëbēnt

lëbe

lëbest

lëbet

lëben

lëbet

lëbent 
NHG.

$\begin{array}{clll}\text { Sing. I. lege } & \text { höre } & \text { salbe } & \text { lebe } \\ \text { 2. legst } & \text { hörst } & \text { salbst } & \text { lebst } \\ \text { 3. legt } & \text { hört } & \text { salbt } & \text { lebt } \\ \text { Plur. I. legen } & \text { hören } & \text { salben } & \text { leben } \\ \text { 2. legt } & \text { hört } & \text { salbt } & \text { lebt } \\ \text { 3. legen } & \text { hören } & \text { salben } & \text { leben }\end{array}$

Subjunctive.

OHG.

Sing. I. legge

hōre

2. leggēs(t) hōrēs(t)

3. legge salbo

salbōs(t)

salbo

salbōm

salbōt

salbōn lëbe

lëbēs(t)

lëbe

lëbēm

lëbēt

lëbēn

\section{MHG.}

Sing. r. lege

2. legest

3. lege

Plur. I. legen

2. leget

3. legen hœre

hœrest

hœre

hœren

hœret

hœren salbe

salbest

salbe

salben

salbet

salben

lëbe

lëbest

lëbe

lëben

lëbet

lëben

\section{NHG.}

Sing. I. lege

2. legest

3. lege

Plur. I. legen

2. leget

3. legen höre

hörest

höre

hören

höret

hören salbe

salbest

salbe

salben

salbet

salben lebe

lebest

lebe

leben

lebet

leben 
Imperative.

OHG.

Sing. 2. legi

hōri

salbo

lëbe

Plur. I. leggemēs, hōremēs salbōmēs (-ēn)

2. legget

hōret

salbōt

lëbet

MHG.
Sing. 2. lege

Plur. I. legen

2. leget

Sing. 2. lege

Plur. 2. legt

OHG.
OHG. leggen

MHG. legen

NHG. legen hœre

hœren

hœret

NHG.

höre

hört

Infinitive.

hōren

hœren

hören salbe

salben

salbet

salbe

salbt

salbōn

salben

salben lëbēmēs

lëbe

lëben

lëbet

lebe

lebt

lëbēn

lëben

leben

\section{Gerund.}

Gen. leggennes hōrennes salbōnnes lëbēnnes

Dat. leggenne hōrenne salbōnne lëbēnne MHG.

Gen. legennes hœrennes salbennes lëbennes

Dat. legenne hœrenne salbenne lëbenne NHG. legend. hörend. salbend. lebend.

Participle.
OHG. leggenti
hōrenti
salbōnti hœrende salbende
MHG. legende
NHG. legend salbend
lëbēnti
lëbende
lebend 
Preterite.

Indicative.

OHG.

Sing. I. legita

2. legitōs(t)

3. legita

Plur. I. legitum, hōrtum (-un)

2. legitut

3. legitun

Sing. I. legete

2. legetest

3. legete

Plur. x. legeten

2. legetet

3. legeten

Sing. I. legte

2. legtest

3. legte

Plur. I. legten

2. legtet

3. legten

\section{hōrta}

hōrtut

hōrtun salbōta

salbōtōs(t)

salbōta

salbōtum

salbōtut

salbōtun

\section{MHG.}

hōrte

hōrtest

hōrte

hōrten

hōrtet

hōrten

\section{NHG.}

hörte

hörtest

hörte

hörten

hörtet

hörten salbete

salbetest

salbete

salbeten

salbetet

salbeten

salbte

salbtest

salbte

salbten

salbtet

salbten lëbēta

lëbētōs(t)

lëbēta

lëbētum

lëbētut

lëbētun

lëbete

lëbetest

lëbete

lëbeten

lëbetet

lëbeten

lebte

lebtest

lebte

lebten

lebtet

lebten

Subjunctive.

\section{OHG.}

Sing. I. legiti

2. $\operatorname{legitis}(\mathrm{t})$

3. legiti

Plur. I. legitīm, (-in)

2. legitīt

3. legitin hōrti

salbōti

salbōtīs(t)

salbōti

salbōtīm

salbōtīt

salbōtīn

$\begin{array}{ll}\text { hōrtīt } & \text { salbōtīt } \\ \text { hōrtīn } & \text { salbōtīn }\end{array}$

lëbēti

lëbētīs(t)

lëbēti

lëbētīm

lëbētit

lëbētīn 
. MHG.

Sing. r. legete

2. legetest

3. legete

Plur. r. legeten

2. legetet

3. legeten

Sing. I. legte

2. legtest

3. legte

Plur. I. legten

2. legtet

3. legten hōrte

hōrtest

hōrte

hörten

hörtet

hōrten salbete

salbetest

salbete

salbeten

salbetet

salbeten

NHG.

\section{salbte}

salbtest

salbte

salbten

salbtet

salbten lëbete

lëbetest

lëbete

lëbeten

lëbetet

lëbeten hörten

hörtet

hörten

Participle.

\begin{tabular}{|c|c|c|c|c|}
\hline OHG. & $\left\{\begin{array}{l}\text { gilegit } \\
\text { gilegitēr }\end{array}\right.$ & $\begin{array}{l}\text { gihōrit } \\
\text { gihōrtēr }\end{array}$ & $\begin{array}{l}\text { gisalbōt } \\
\text { gisalbōtēr }\end{array}$ & $\begin{array}{l}\text { gilëbēt } \\
\text { gilëbētēr }\end{array}$ \\
\hline MHG. & gele & $\left\{\begin{array}{l}\text { gehœret } \\
\text { gehōrt }\end{array}\right.$ & gesalbet & gelëbet \\
\hline $\mathrm{HC}$ & ge & gehört & gesalbt & gelebt \\
\hline
\end{tabular}

\section{The Endings of Weak Verbs.}

\$528. Present: In the oldest period of the language the indic. first pers. singular of Class I ended in -iu, which became $\cdot u$ after the analogy of the strong verbs in the early part of the ninth century. In Classes II and III the final $\cdot m$ became $\cdot n$ in the ninth century. This $\cdot \mathbf{n}$ remained in early MHG., but during the MHG. period the first pers. sing. was formed after the analogy of Class $I$ and the strong verbs. The ending $\cdot i$ in the imperative of the second pers. singular goes back to an original eje, which regularly became $\mathbf{1}$ in prim. Germanic. On the other endings of all forms of the present in OHG., see \$\$476-80. The vowels 
$\mathbf{i}, \mathbf{e}, \mathbf{o}, \mathbf{u}, \overline{\mathrm{e}}, \overline{\mathrm{o}}$, in the OHG. endings were all weakened to e in MHG. $(\$ 170)$, so that the old distinction between the three classes of weak verbs disappeared. NHG. examples of verbs which belonged to Class II in OHG. are : beten (OHG. bëtōn), danken (OHG. dankōn), and similarly dienen, heischen (OHG. eiscōn), fordern, jagen, lecken, lohnen, machen, mahnen, minnen, rauben, reden, regnen, schaden, schauen (OHG. scouwōn), segnen, spähen, spielen, zieren. Examples of NHG. verbs which belonged to Class III in OHG. are: fasten (OHG. fastēn), folgen (OHG. folgēn), and similarly fragen, faulen, haben, kleben, lernen, sagen, schweben, sorgen, trauen, warten, wohnen. Some verbs had double forms, as hassen (OHG. hazzēn, hazzōn), holen (OHG. holōn, holēn), and similarly klagen, loben, mahlen, sparen. On the loss of the e in NHG. legst, legt, \&c., see $\$ 174$.

§529. Preterite: The vowels $\mathbf{a}, \mathbf{i}, \mathbf{u}, \overline{\mathbf{e}}, \overline{\mathbf{i}}, \overline{\mathbf{o}}$ in the OHG. endings were all weakened to $e$ in $M H G$., so that the indicative and subjunctive fell together in form. And in like manner the past participle of Class I, sub-division (a), fell together with the past participle of Classes II and III. On the loss of e in NHG. legte, lebte, \&c., see \$174.

\section{General Remarks on the Weak Verbs.}

$\S 530$. Present: The double consonants in Class I, subdivision $(a)$, began to be simplified in late OHG.

\$531. Preterite: The weak preterite is a special Germanic formation, and many points connected with its origin are still uncertain. Some scholars are inclined to regard it as a periphrastic formation which was originally confined to denominative verbs, and then at a later period became extended to primary verbs as well. The OHG. endings -ta, -tōs, -ta, -tum, -tut, -tun would thus represent an old aorist formed from the root dhē-, put, place (Gr. $\tau i-\theta \eta-\mu l$ ), which stands in ablaut relation to OE. dōn, OHG. tuon, to do. The old preterite (perfect) of this verb has been pre- 
served in the preterite plural of Gothic weak verbs, as hausi-dēdum (we heard), -dēdup, -dēdun beside the OHG. pret. plural of tuon : tātum, tātut, tātun. But it is also probable that the dental in the OHG. preterite partly stands in close relationship to the dental in the past participle. The $\mathbf{i}$ in the preterite of Class I, sub-division (a), -ita, -itōs, $\& c$. , was from the past participle. Through the weakening of the OHG. endings in MHG., the preterite of Class I, sub-division $(a)$, fell together with Classes II and III, so that in MHG. the weak verbs are generally divided into two classes according as the preterite ends in te or ete. But already in MHG. verbs which regularly had ete often took -te after the analogy of Class I (b). In NHG. the usual form is -te, but from the seventeenth century onwards verbs whose stems end in a dental regularly have -ete, as leitete, redete, rettete, \&c. In $\mathrm{NHG}$. the preterite and past participle are generally formed direct from the present, so that when the present has umlaut the preterite and past participle have it also. But in MHG. those verbs which formed their preterite in -te did not have umlaut, as fuillen, fürhten, hœnen, hüeten, rüemen, sæjen, senken, setzen, vellen, wünschen, pret. fulte, forhte, hōnte, huote, ruomde, sāte, sancte, sazte, valte, wunschte, but NHG. füllte, fürchtete, höhnte, hütete, rühmte, säte, senkte, setzte, fällte, wünschte. The old distinction between the vowel of the present and preterite has been preserved in a few verbs, viz. brennen, brannte (MHG. brante, OHG. branta), and similarly in kennen, nennen, rennen, senden, wenden. bringen, brachte (M HG. brāhte, pret. subj. bræhte); denken, dachte (MHG. dāhte, pret. subj. dæhte); dünken, older NHG. also dunken (MHG. dünken, dunken), MHG. pret. indic. dūhte, subj. diuhte; NHG. dünkte is a new formation, and däucht, däuchte, gedäucht have their stem vowel from the pret. subjunctive.

In a few cases new presents have been formed from the 
old preterites, as atzen, bestallen, schatzen beside the regular forms ätzen, bestellen, schätzen.

$\$$ 532. Past Participle: In the oldest period of the language verbs of Class I, sub-division $(a)$, had -it in the uninflected and .iter in the inflected form, but those of sub-division $(b)$ had .it in the uninflected and têr in the inflected form. This distinction was preserved in MHG., which accounts for the past participle having both an umlauted and non-umlauted form. An old isolated form of this kind has been preserved in behaftet beside heften. In NHG. the old distinction between the inflected and uninflected form has been given up. Those verbs which now have -te in the preterite have $-t$ in the past participle, and those which have ete in the preterite have -et in the past participle, but we have the old isolated form in beredt beside geredet. The verbs, which have preserved the old distinction between the vowel of the present and preterite, have preserved it also in the past participle, as gebrannt, genannt, \&c.

$\S 533$. In OHG. habēn was a weak verb of Class III, and was conjugated like lëbēn ( $\$$ 527). In late OHG. the present habēn was contracted into hān, which in MHG. came to be used chiefly as an auxiliary verb beside haben used as a principal verb. The contracted forms of the present were in MHG. hān, hāst, hāt, pl. hān, hāt, hān, whence NHG. hast, hat. The other forms of the present have not been preserved in NHG. From the present hān there was formed in MHG. a new preterite hāte, hātest, \&c. beside hæte, hætest, \&c. which were used both for the indicative and subjunctive, whence NHG. hatte, hattest, \&c. and subjunctive hätte, hättest, \&c.

\section{Minor Groups.}

\section{A. Preterite-Presents.}

$\S 534$. These verbs were originally unreduplicated perfects, which acquired a present meaning like Greek oi $\delta$, 
Latin nōvī, I know. In prim. Germanic a new weak preterite, an infinitive, a present participle, and in some verbs a strong past participle, were formed from the stem form of the plural. They are inflected in the present like the preterite of strong verbs, except that the second pers. singular has the same stem vowel as the first and third persons, and has also preserved the old ending $-t$ (\$ 479). In NHG. the second pers. singular darfst (MHG. darft), sollst (MHG. solt), magst (MHG. maht), have been formed after the analogy of weisst (MHG. weist), kannst (MHG. kanst), musst (MHG. muost). In early NHG. the third pers. singular often ended in $t$ after the analogy of other verbs. In MHG. the present plural and infinitive : tügen, günnen, künnen, dürfen, mügen, and müezen probably had umlaut after the analogy of the subjunctive. Then the $\ddot{\mathbf{u}}$ in guinnen, künnen regularly became $\ddot{o}$ in NHG. (\$101). In NHG. the pres. plural, the infinitive, and pret. subjunctive have the umlaut of the vowel which occurs in the pret. indicative. The pret. subjunctive had umlaut in MHG., which has remained in NHG. except in sollte (MHG. sölte beside solte). The NHG. past participle has been formed direct from the pret. indicative.

\$535. Class I : OHG. and MHG. weiz, weist, weiz, pl. OHG. wizzum, MHG. wizzen, NHG. weiss, weisst, weiss, wissen; pret. indic. OHG. wissa, wëssa (wista, wësta), MHG. wisse, wësse (wiste, wëste, late MHG. wuste, woste, through the influence of the w): only the form wusste has survived in NHG.; NHG. pret. subj. wuisste is a new formation from the pret. indicative; inf. OHG. wizzan, MHG. wizzen, NHG. wissen; pp. OHG. giwizzan, MHG. gewizzen beside gewëst formed from the pret. wëste; NHG. gewusst formed from wusste. The NHG. imperative wisse is a new formation. The imperative did not exist in OHG. and MHG.

§ 536. Class II : OHG. toug, it avails, plural tugun, pret. 
tohta; MHG. touc, pl. tugen (tügen), inf. tugen (tuigen). A new inf. tougen was formed from touc in MHG., and then the verb became weak as in NHG. es taugt, inf. taugen.

§ 537. Class III : OHG. kan, kanst, kan, pl. kunnum, pret. konda (with o difficult to explain), inf. kunnan; MHG. kan, kanst, kan, pl. and inf. kunnen (künnen), pret. indic. kunde (konde), subj. kunde (kuinde); NHG. kann, kannst, kann, pl. and inf. können (from künnen), pret. indic. konnte (from konde), subj. könnte and pp. gekonnt formed from konnte.

MHG. gan (from *ge-an), pl. and inf. gunnen (günnen), has become weak in NHG. : gönnen, gönnte.

OHG. darf, darft, darf, pl. durfum, pret. dorfta, inf. durfan; MHG. darf, darft, darf, pl. and inf. durfen (dürfen), pret. indic. dorfte, subj. dörfte; NHG. darf, darfst, darf, pl. and inf. dürfen (from MHG. dürfen), pret. indic. durfte formed from MHG. durfen; subj. dürfte and pp. gedurft, formed from pret. durfte.

§ 538. Class IV : OHG. scal, scalt, scal, pl. sculum, pret. scolta, inf. scolan ( $\$ 57)$. Forms without c occur already in OHG., as sal, solta, cp. OE. sceal, beside Mod. Northern Engl. dial. sal = shall; sol, solt, sol with o from the inf. and pret. were common in late OHG.; MHG. sol (sal), solt (salt), sol (sal), pl. and inf. suln (suiln), pret. indic. solde (solte), subj. solte (sölte); NHG. soll, sollst, soll, pl. and inf. sollen formed from soll, pret. indic. and subj. sollte (MHG. solte), pp. gesollt formed from sollte.

§539. Class V: OHG. mag, maht, mag, pl. magum (mugum after the analogy of sculum), pret. mahta (mohta), inf. magan (mugan); MHG. mac, maht, mac, pl. magen (mugen, mügen), pret. mahte (mohte), subj. mähte (möhte), inf. mugen (mügen); NHG. mag, magst (a new formation from mag), pl. and inf. mögen, pret. indic. mochte 
from MHG. mohte, subj. möchte from MHG. möhte, pp. gemocht from pret. mochte.

In OHG. several of the forms were new formations which took place in the prehistoric period of the language. The verb probably belonged originally to Class VI.

§ 540. Class VI: OHG. muoz, muost, muoz, pl. muoz um, pret. indic. muosa; M HG. muoz, muost, muoz, pl. and inf. muiezen, pret. indic. muose (muoste with $t$ from other preterites), subj. müese (muieste); NHG. muss, musst, muss, pl. and inf. müssen from MHG. muiezen, pret. indic. musste from MHG. muoste, subj. müsste from MHG. müeste, pp. gemusst formed from musste. The stem vowel in all the NHG. forms has undergone shortening (§ 139).

\section{B. VERBS IN -mi.}

\$ 541. The first pers. sing. pres. indicative of the IndoGermanic verb ended either in $\overline{-0}$ or $\cdot \mathrm{mi}$ (cp. the Greek verbs in $-\omega$ and $-\mu \iota$, like $\phi^{\prime} \rho \omega$ and $\left.\tau i \theta \eta \mu, \& c.\right)$. See $\$ 471$. To the verbs in $\cdot \overline{0}$ belong all the regular Germanic verbs; of the verbs in -mi only scanty remains have been preserved; they are distinguished by the fact that the first pers. sing. pres. indicative ends in $\cdot \mathbf{m}$, which became $\cdot \mathbf{n}$ in OHG. in the ninth century. Here belong the following OHG. verbs :-

\$542. I. The Substantive Verb.

\section{Present.}

Indicative.

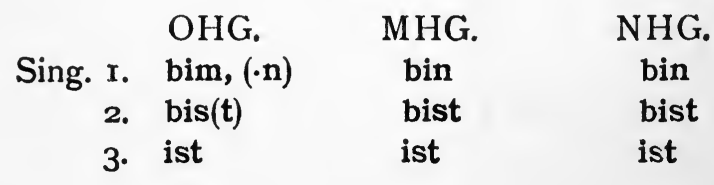


OHG.

Plur. I. birum, $(\cdot \mathbf{n})$

2. birut

3. $\operatorname{sint}$
MHG.

birn, (sint)

birt, (sit)

sint
NHG.

sind

seid

sind

Subjunctive.

Sing. I. sī

2. $\operatorname{sis}(t)$

3. $s \overline{1}$

Plur. I. sim, (-n)

2. sit

3. $\sin$ sī, (sie) sīst, (siest) sī, (sīe) sin, (sien)

sit, (siet) sinn, (sien) sei seiest sei seien seiet seien

Imperative.

Sing. 2. wis Plur. 2. wëset, (sit) wis

wëset, (sit) sei seid

Infinitive. wësan, $(\sin ) \quad$ wësen, $(\sin ) \quad$ sein

Participle. wësanti wësende seiend

Preterite.

Indicative.

Sing. I. was

2. wāri

3. was

Plur. I. wārum

2. wārut

3. wārun was

wære

was

wāren

wāret

wāren war warst

war

waren

wart

waren

Subjunctive.

Sing. I. wāri

2. wārīs(t)

3. wāri wære

wærest

wære wäre wärest wäre 


$\begin{array}{rlll} & \text { OHG. } & \text { MHG. } & \text { NHG. } \\ \text { Plur. I. } & \text { wārim } & \text { wæren } & \text { wären } \\ \text { 2. wārìt } & \text { wæret } & \text { wäret } \\ \text { 3. } & \text { wārīn } & \text { wæren } & \text { wären }\end{array}$

Participle.

gewësen

gewesen

The OHG. pres. indicative forms ist, sint, and the pres. subjunctive were formed from the root es. The forms with b- (bim, bist, birum, birut) probably arose from a contamination of the root es- with the root bheu- (= Lat. fu.). The regular OHG. fornis would have been *im, *is, *irum, *irut, the last two forms with preterite endings. On the original forms of the present tense, see $\S 471$. In the oldest period of the German language all forms of the verb 'to $b e$ ' were supplied by wësan except the pres. indicative and subjunctive, but in NHG. the forms from wesen have become restricted to the pret. indicative and subjunctive, and the past participle. On the history of the preterite forms, see $\$ 507$.

The forms birn, birt disappeared in the thirteenth century, their place being taken by the subjunctive $\sin$ (Middle German also sint, the third person), sit, whence NHG. sind, seid. In the fourteenth century the pres. subjunctive began to take an e after the analogy of the other verbs. These dissyllabic forms have become generalized in NHG. before a following consonant, whence sei, but seiest, seien, and similarly in the pres. participle. In the imperative, the subjunctive form sit was used beside wëset already in OHG., whence MHG. sit and NHG. seid. The NHG. second pers. singular sei is a new formation from the subjunctive, and similarly the pres. participle seiend. The OHG. infinitive sin was a new formation from the subjunctive. 
$\S 543$.

2. The Verb tun.

\section{Present.}

Indicative.

$\mathrm{OHG}$.

Sing. I. tuom, (-n)

2. $\operatorname{tuos}(t)$

3. tuot

Plur. I. tuomes, (tuon)

2. tuot

3. tuont
MHG.

tuost

tuot

tuon

tuot

tuont tuon, (tuo)

NHG.

tue tust

tut

tun

tut

tun

tun

Preterite.

Indicative.

Sing. I. tëta

2. tāti

3. tëta

Plur. I. tātum, (-n)

2. tātut

3. tātun tëte

tæte

tëte

tāten

tātet

tāten tat tatst

tat

taten

tatet

taten

Participle.

gitān

getān

getan

The final $\mathbf{n}$ of the first pers. singular began to disappear in $\mathrm{MHG}$.

MHG. tuo would regularly have become tu in NHG., tue is a new formation after the analogy of the first pers. sing. of other verbs. The forms of the pres. subjunctive were in MHG. tuo, tuost, tuo, pl. tuon, tuot, tuon. The uo would regularly have become $\overline{\mathbf{u}}$ in $\mathrm{NHG}_{\text {. }}(\$ 137)$, but tue, tuest, \&c. have e after the analogy of the pres. subjunctive of other verbs. The pret. indicative is inflected in $\mathrm{OHG}$, and $\mathrm{MHG}$. like rëman $(\$$ 474) except that the 
first and third pers. singular have reduplication. In NHG. the singular has been formed from the plural stem form tat. The pret. subjunctive OHG. tāti, tātīs $(t)$, \&c., MHG. tæte, tætest, NHG. täte, tätest, are inflected like nëman ( $\$ 474)$.

\$544. 3. The Verbs gehen, stehen.

The OHG. strong verbs gangan ( $\$ 514)$ and stantan (§ 511), which regularly formed their preterites giang, stuont, had, beside these, short present forms. The Alemanic dialect had the forms gān, stān, while the Bavarian and Franconian dialects mostly had the forms gēn, stēn which correspond to NHG. gehen and stehen. - On the dissyllabic pronunciation of the NHG. forms see $\S 181$. The conjugation of gēn will serve for both verbs.

\section{Present.}

Indicative.

\section{OHG. MHG.}

Sing. I. gēm, (-n)

2. $\operatorname{gēs}(t)$

3. gèt

Plur. I. gēmēs, (gēn)

2. gēt

3. gēnt gēn, (gē)

gēst

gèt

gēn

gēt

gēnt
NHG.

gehe

gehst

geht

gehen

geht

gehen

Subjunctive.

Sing. I. gē

2. gēs(t)

3. $g \bar{e}$

Plur. I. gēn

2. gēt

3. gēn gē

gēst

gē

gēn

gēt

gēn gehe

gehest

gehe

gehen

gehet

gehen

Infinitive.

gēn

gēn

gehen 
The origin of the NHG. dissyllabic forms in the subjunctive is the same as that in tun.

\section{\$545. ThE Verb wollen.}

The present tense of this verb was originally an optative (subjunctive) form of a verb in -mi, which already in prim. Germanic came to be used indicatively. To this was formed a new subjunctive and a weak preterite. The old optative forms were preserved in Gothic, as wiljáu, wileis, wili, pl. wileima, wileip, wileina, cp. Lat. velim, velis, velit, pl. velimus, velitis, velint, but in OHG. they were only preserved in the singular, all other forms of the present were from the causative verb wellen = Gothic waljan, to choose, which accounts for the fact that these forms had in OHG. the same inflexions as an ordinary weak verb of class I ( $\$ \mathbf{5 2 7})$. In the Franconian dialects (Middle German) of the OHG. period the e in the various forms of the present became o either through the influence of the preceding $\mathbf{w}$ (cp. $\S 65$ ) or else from analogy of the $o$ in the preterite, whence the NHG. forms wollen, wollt, wolle, \&c.

\section{Present.}

Indicative.

\section{OHG.}

Sing. I. willu

2. wili

3. wili

Plur. I. wellemēs (wellēn)

2. wellet

3. wellent
MHG.

wil

wil, (wilt)

wil

wellen, (weln)

wellet, (welt)

wellen, (weln)
NHG.

will

willst

will

wollen

wollt

wollen

Subjunctive.

Sing. I. welle

2. wellēs(t)

3. welle welle

wellest

welle wolle wollest wolle 
OHG.

Plur. I. wellèm, (-n)

2. wellèt

3. wellēn

wellen

wellenti
MHG.

wellen

wellet

wellen

Infinitive.

wellen

wollen

Participle.

wellende

wollend

Preterite.

Indicative.

wolta

[like hōrta, § 527]

wolte, (wolde)

wollte

Subjunctive.

wolti

wolte, (wölte)

wollte

[like hōrti, § 527]

\section{Participle.}

gewellet, (gewellt) gewollt

OHG. willu was a new formation after the analogy of the first pers. of other verbs. In MHG. the present singular was remodelled after the analogy of the preteritepresents. NHG. willst has -st after the analogy of the preterite-presents. The NHG. imperative wolle is a new formation. The pret. subj., like sollte, does not have umlaut. The pp. does not occur in OHG., it is a late MHG. new formation. NHG. pp. gewollt is formed from the pret. wollte. 


\section{CHAPTER XVIII}

\section{ADVERBS.}

$\$$ 546. IN this chapter we shall chiefly deal with the formation of adverbs from adjectives, and with the inflected forms of nouns and adjectives used adverbially.

547. In OHG. adverbs were formed from adjectives by adding $\cdot 0$ to the uninflected form of the adjective when it ended in a consonant. When the adjective ended in -i (ja., jo-stems, $\S 400$ ) the -i was dropped before the adverbial ending $\cdot 0$; and those adjectives, which had an umlauted stem-vowel, did not have it in the adverbs. The ending • o (Gothic ·ō, Indg. •õd) was originally an ablative ending (cp. $\$$ 405). Examples are: OHG. adjectives ëban, eben, gilìh, gleich, lūt, laut, rëht, recht, ubil, übel; engi, eng, festi, fest, scōni, schön, stilli, still, swāri, schwer, beside the adverbs ëbano, gilicho, lūto, rëhto, ubilo; ango, fasto, scōno, stillo, swāro.

In MHG. the final $\cdot 0$ of the adverbs and the final $\cdot i$ of the adjectives were weakened to -e., so that when the adjective ended in a consonant the only difference between the adjective and adverb was the final ee in the latter, as adj. gelīch, lūt, rëht beside adv. gelīche, lūte, rëhte. When the adjective ended in $e$ the only difference between the adjective and adverb was the presence or absence of umlaut, as adj. enge, herte, schœne, senfte, soft, spæte, spät, stille, süeze, süss, swære, veste beside adv. ange, harte, schōne, sanfte, spāte, stille, suoze, swāre, vaste.

In NHG. this distinction between the adjective and adverb has disappeared. The uninflected form of the 
adjective is now used as an adverb except in the case of hart and sanft which are originally the adverbial forms, and of lang beside lange. The adjectives fest and schön beside the adverbs fast and schon have been differentiated in meaning. NHG. examples are : böse, eben, eng, gut, müde, öde, schnell, schwer, spät, süss, \&c.

\$548. The -licho (MHG. liche) in adverbs formed from adjectives ending in -lich ( $\$ 324$ ) came to be regarded as an adverbial suffix already in OHG., as in OHG. angustlicho, ängstlich, ëbanlicho, evenly, fastlicho, firmly, frawalīcho, fröhlich, geistlīcho, geistlich, wārlīcho, wahr. lich, \&c.

In NHG. lich is used to form a large number of adverbs, as ewiglich, fälschlich, freilich, höchlich, kühnlich, kürzlich, neulich, schwerlich, sicherlich, \&c.

§549. In OHG. the comparative degree of adverbs ended in $\bar{o} \mathbf{r}$, and the superlative mostly ended in -ōst, but also sometimes in -ist ( $\$$ 405-8), as OHG. langōr, langōst ; fastōr, fastōst ; jungist.

In MHG. the endings .ōr, .ōst, .ist were weakened to .er, est and thus fell together with the endings of the comparative and superlative degrees of adjectives ( $\$ \$ 406$, 408), so that the only difference between the adjectives and adverbs was the presence or absence of umlaut, as adj. lanc, lenger, lengest, beside adv, lange, langer, langest.

This distinction has disappeared in NHG. The comparative and superlative degrees of adverbs are now the same as the corresponding uninflected forms of the adjectives, as länger; längst, baldigst, gnädigst, höchst, jüngst, möglichst, nächst, \&c. But eher, ehestens and lieber, am liebsten are used as the comparative and superlative of bald and gern. The NHG. inflected superlative in combination with the definite article and a preposition was rare in OHG. and MHG., as in NHG. am besten, aufs 
beste, zum besten, \&c. On the ending ens as in NHG. bestens, meistens, wenigstens, \&c., see $\$ 550$.

\$550. A large number of NHG. adverbs consists of the various cases of nouns and adjectives used adverbially, as acc. sing. alleweile, diesseit, gar, genug, jenseit, viel, weg, wenig, \&c. ; instr. sing. heuer (OHG. hiuru), heute (OHG. hiutu); gen. sing. derart, dergestalt, derzeit, jederzeit, kurzerhand, mittlerweile; einigermassen, folgendermassen, gewisser. massen; ausnahmsweise, beispielsweise, bekannterweise, dummerweise, gleicherweise (MHG. glīcher wise), glücklicherweise, haufenweise, stufenweise, unverschämterweise. The ending $\cdot s$ belonged originally to the gen. singular of masculine and neuter o-stems only, and then at a later period it became extended to other stems and cases; regular forms are: abends, anfangs, blindlings, flugs (MHG. fluges), häuptlings, keineswegs, morgens, rings, tags; anders (OHG. anderes), bereits, besonders, durchgehends, eilends, einst (with excrescent -t), längs (MHG. lenges), links, öfters, rechts, stets (MHG. stætes), stillschweigends, stracks, unversehens, vergebens (MHG. ver. gëbenes), zusehends; heimwärts (MHG. wërtes, gen. of wërt, worth), rückwärts, seitwärts; then after the analogy of such words there have been formed: nachts (already in OHG. nahtes); andernfalls, ebenfalls, gleichfalls, jedenfalls, keinenfalls; grösstenteils, meistenteils ; abseits, abwegs, angesichts, nachmals, unterwegs, voralters, vormals; damals, irgends, jemals, mehrmals, niemals, nochmals, nirgends; andrerseits beside anderseits, diesseits, einerseits, jenseits, meinerseits; allerseits, beiderseits; allerdings (MHG. gen. pl. aller dinge), allerorts, neuerdings, schlechterdings; vollends (MHG. dat. pl. vollen); NHG. ens from the weak genitive ending $\cdot \mathrm{en}+\cdot \mathbf{s}$, as bestens, höchstens, meistens, ubrigens, wenigstens, \&c.; this analogical formation is especially common in numerals, as erstens, zweitens, drittens, $\& c$. see $\$ 430$; gen. plural allerorten, allerwege ; dat. plural 
allenthalben (already MHG. allenthalben), bisweilen, deswegen, einstweilen, jeweilen, weiland (OHG. wilōn, MHG. wilent with excrescent $\cdot t)$.

§551. In NHG. many adverbs are merely the cases of nouns and adjectives governed by prepositions, as abhanden, beinahe, fürwahr, insbesondere, insgesamt, insofern, insoweit, inwiefern, inwieweit, uberall, vonseiten, vorhanden, zufrieden, zuhaus, \&c. 


\section{INDEX}

The numbers after a word refer to the paragraphs in the Grammar.

aal II $7,298,349$.

aar 386.

aas $I 17$.

ab 9I, I 7 I (MHG.), 228. abend 117,174 (MHG.). abends $55^{\circ}$.

abenteuer 128, 346.

aber 106.

aber- 299.

aberglaube 299.

abername 299.

abersaat 299 .

aberwandel 299.

aberwitz 299.

abgeschaben 5 II.

abgott 346, 35I.

abgötterei 30 r.

abhanden $38 \mathrm{I}, 55 \mathrm{I}$.

abhängig 322 .

ablass 313,346 .

abseits $55^{\circ}$.

abtei 30 .

abteil $3^{1} 3$.

abwegs 550 .

achse 282 .

achsel 282, 299.

acht $n$. I19, 139, I74, 368.

acht, num. 34(OHG.), 59 (OHG.), 9I, I62 (OHG.), I92(OHG.), 28I, 4I3

achte 422 .

achtlos 325 .

achtlosigkeit 303 .

achtsam 326 .

achtung 312 .

achtzehn 4 I3.

achtzehnte 422 .

achtzig $4 \mathrm{r} 3$.

achtzigste 422 .

ächzen 343 .

acker $3 \mathrm{I}$ (OHG.), 59

(OHG.), 8o(MHG.),
9I, I65(OHG.), I 72

(MHG.), 214(OHG.),

$286,350$.

ackern $330,340$.

adel 90, ro6.

adelig 289.

adeln 340 .

ader II 7 .

adler 386 .

adresse 28 .

affe 174,362 .

after- 299 .

afterblatt 299.

afterkiel 299.

afterkind 299.

afterkritik 299.

afterlehre 299.

aftermiete 299.

aftermuse 299.

afterpacht 299.

afterrede 299.

ahle II 7 .

ahne $174,3^{82}$.

ähnlich 21, 90, 107.

ähre 79(M HG.), 90, 107, 279, 346 .

albe 346 .

albern 235.

all 220 (M HG.), 224, 469 .

allenthalben $27, \quad 272$, 550.

allerdings 27,550 .

allerhand $\mathrm{r} 74,38 \mathrm{r}$.

allerlei 426.

allerorten 550 .

allerorts $55^{\circ}$.

allerseits $55^{\circ}$

allerwege $55^{\circ}$.

alleweile $55^{\circ}$.

allgemein 328 .

allmächtig 26, 322 .

allmählich 288.

alltäglich 26.

almosen 137 . alp 253.

alt 2I, 60(OHG.), 79

(MHG.), 90, 93, 182, 244, 269, 316, 406, 408.

älteln 340 .

alter 269 .

altern 340.

altertum 3 I $\mathrm{r}$.

amboss 122, 139, 247.

ameise $130,264,346$.

ammer II 4 .

ampfer $3^{86 .}$

amsel 293.

amt I 74, 256.

amtsdiener 174 .

an 9I, I 7I(MHG.).

andacht 299.

ander I 79, I82, 274, 422, 423,469 .

andernfalls $55^{\circ}$.

anders 550 .

anderseits $55^{\circ}$.

anderthalb 272, 427 .

andrerseits $55^{\circ}$.

anfangs $55^{\circ}$.

angel 346 .

angenehm 120, 185. .

angesichts 550 .

angst 295, 346, 375

ängstlich, 548 .

ängstlichkeit $3 \circ 3$.

anhängsel 309 .

anheimeln 340 .

ankormmling 306 .

ankunft 299.

anmerkung 29.

ansässig I 20, 139.

anstalt 376 .

ant- 299.

antlitz I 74, 299(OHG.), $262,299,333,363$.

antwort 26, 299, 333 .

antworten $25,33^{\circ}$. 
anwalt 386.
apfel 92, 21 $4(\mathrm{OHG}$.), 374.

appetit 28.

April I 74, 386 .

ar 103.

arbeit 130,376 .

arbeiten 330 .

arbeitsam 326.

arbeitsamkeit 303

arg 9I, 292.

ärgern 340.

ärgernis 308 .

arglos 325 .

argwohn 118 .

arm 9I, 245, 246, 349, $406,408$.

armbrust 346 .

armee 28.

ärmel 299.

armut 174,346 .

arsch 104.

art 104, 346, 376 .

arzt 104, 350.

ärztlich 104.

asche 287,367 .

ast 190,203 (OHG.), 374 .

atem I I 7 I 75, 246.

atmung 174 .

atzen 531 .

ätzen $53 \mathrm{I}$.

auch 86(MHG.), I3I, 288.

aue 79(MHG.), т31, 221

(OHG.), 234.

auf 126,217 (OHG.). aufmerksamkeit 303 . aufwand 3 r 3 . auge 76 (OHG.), 86

(MHG.), I3I, 218

(OHG.), $3^{88}$.

augenfallig $3^{28}$.

augenlied 314 .

aus $126,224,263$.

ausfuhrbar 318 . ausführlich 26 .

ausgiebig 322 .

auskunftsmittel $3 \times 4$.

ausländisch $3^{2} 3$.

ausmergeln 340 .

ausnahmsweise $55^{\circ}$.

aussen 126 . äussere 412.

ausserhalb 4 I2.

äussern 127.

auswärts 27.

axt 272, 375 .

bach 374 .

bächlein 300 .

backen 383,47 I(OHG.), 5 II.

băcker 302.

bäckerei 28 , 301.

bad 89, 106, 357, 398.

Baden 357.

baden 106.

bähen roo.

bahn 106, 280, 368 .

bahnen 330 .

bahre 117,185 .

bald 91, 275, 549 .

baldigst 549 .

balg 292, 374 .

balken 174,383 .

ballen $3^{8} 3$.

balsam 184 .

band $9 r, 185,268,298$, 358.

bändigen 342 .

bang 406.

bank 250, 346 .

bannen $5^{14}$.

-bar 24, 26, 184, 318, 406.

bär 90, 108, 382 .

barfuss 139 .

barmherzig 26, 328 . barmherzigkeit 26 .

barren 383 .

barsch 104, 294, 406.

bart 104, 269.

base 106 .

bass 90.

bau 126,365 .

bauch 126, 288.

bauen 126, 234 .

bauer $128,354,382$.

baum 21, I31, I32, 173

(MHG.), 298, 350.

bäumen 132 .

baumgarten 174 (MHG.).

be- 332 .

beantworten $33^{2}$. bedarf 299.

bedecken $33^{2}$.

bedenklich 317,324 .

bedingen 496 .

bedrängnis 308 .

bedürfnis 308 .

be-endigen $33^{2}$.

be-engen $33^{2}$.

be-erdigen, $33^{2}, 34^{2}$.

beere 346 .

beet II 5 .

befähigen 332 .

befehl 299.

befehlen I08, I67

(OHG.), 283, 284, 485,

499.

befehligen 342 .

befeinden $33^{2}$.

befestigen 332,342 .

befeuchten $33^{2}$.

befinden 332 .

befleissen 492 .

beflügeln $33^{2}$.

befreien $33^{2}$.

befreunden 332 .

befriedigen $33^{2}$.

begeistern $33^{2}, 340$.

begierde 104.

begiessen $33^{2}$.

beginn 299.

beginnen 97, ror, 247, $485,497$.

beglaubigen 332,342 .

beglücken $33^{2}$.

begraben 332 .

begräbnis 308 .

begreifen $33^{2}$.

begreiflich 317,324 .

begrenzen $33^{2}$.

begriff 299.

begünstigen 342 .

begütigen 342 .

behaftet $53^{2}$.

behalten $33^{2}$.

behelf 299.

behende $90,92,174,3^{81}$.

beherbergen $33^{2}$.

behuf 137 .

behülflich 317, 324 .

bei- 299.

bei 125 .

beichte 255, 290, 377 . 
beide 130, 274, 429 . beiderseits $429,55^{\circ}$. beifall 299.

beil 279.

beilage 299 .

bein 82 (MHG.), 130, $253,356$.

beinahe $55^{\mathrm{t}}$.

beinern 319.

beispiel 26, 299.

beispielsweise $55^{\circ}$.

beissen I3(OHG.), 66 (OHG.), 72(OHG), 80 (MHG.), 125, 263, $485,492$.

beistand 299.

beitrag 299.

beizen 262 .

bekannt 9 r.

bekannterweise 550 .

bekanntlich $317,3^{24}$.

bekanntschaft 3 ro.

bekehrung $3^{12}$.

bekennen $33^{2}$.

bekenntnis 308 .

bekräftigen $33^{2}, 34^{2}$.

bekreuzigen $33^{2}$.

belästigen $33^{2}, 342$.

beleg 299.

beliebig 317,322 .

bellen 500 .

bemächtigen 342 .

bemerkung $3^{12}$.

benachrichtigen $33^{2}, 342$.

beneiden 490 .

beobachten 332 .

bequem 120, 174, 317 .

beredt $53^{2}$.

bereichern $33^{2}$.

bereinigen 332 .

bereit 174 .

bereits $178,55^{\circ}$.

berg 55,226 (MHG.), 227, 245, 292, 349.

bergab 27 .

bergen 94, 290, 485, 498.

berichtigen $33^{2}$.

Berliner 302.

Berlinerin 305.

bersten $483,485,502$.

berüchtigt 259 . beruhigen 332.

beruhmtheit 303 .

besänftigen $33^{2}, 342$.

beschädigung $3^{12}$.

beschäftigen 332,342 .

beschatten 60(OHG.), $33^{2}$.

bescheid 299.

bescheiden 516 .

bescheinigen 342 .

beschirmen $33^{2}$.

beschirmung $3^{12}$.

beschlag 299.

beschönigen $332,342$.

beschreiben $33^{2}$.

beschuldigen 342 .

beschwichtigen 259,342 .

besegnen $33^{2}$.

beseitigen 342 .

besen $246,293,386$.

besiegen $33^{2}$.

besinnen 497 .

besinnung $3^{12}$.

besitz 299.

besitzen $33^{2}$.

besitztum 3 II.

besonders $55^{\circ}$.

besorgen 290 .

besorgnis 308 .

besorgung 312 .

besser 90, 92, 225

(OHG.), 263, 406

(OHG.), $4^{\text {Io. }}$

bessern 340 .

besserung I72(MHG.), 312.

bestallen 53 I.

bestand 299.

bestärken $33^{2}$.

beste I74(MHG.), I82,

255, 4 IO.

bestehen 332 .

bestellen $53 \mathrm{I}$.

bestens $549,55^{\circ}$.

bestreitbar 318 .

bestürmen $33^{2}$.

besuch 299.

betäuben 132 .

beteiligen $33^{2}$.

beten II 1 I81, 267, 330, $340,528$.

betonen $33^{2}$. betrachtung $3^{12}$.

betriebsam $3^{1} 7,3^{26}$.

betroffenheit 303 .

betrübnis 308 .

betrügen 493 .

betrügerei 301 .

bett 79(MHG.), I 74, 243 (OHG.), 267,346

(OHG.), 364 .

bettel II 4 .

bettelarm 26 .

bettelei 301 .

betteln 340 .

bettler 302 .

beugen $13^{2}$.

beule 127.

be-urlauben $33^{2}$.

beutel 127.

beuten 127 .

bevőlkern 332, 340 .

bevollmächtigen $33^{2}$.

bewandt $27 \mathrm{I}$.

bewandtnis $27 \mathrm{I}, 308$.

bewegen I08, 483,508 .

beweglich $3^{1} 7,3^{24}$.

beweinen $33^{2}$.

beweis 299.

beweisen 490 .

bewerkstelligen $34^{2}$.

bewohnen $33^{2}$.

beziehen $33^{2}$.

beziffern $33^{2}$.

bezug 299.

bezwingen $33^{2}$.

biber 109.

biegen $76(\mathrm{OHG}),$. (MHG.), 86(MHG.), I 10, I 36, 186(OHG.), 226(MHG.), 227, 290, $484,485,493$.

biegsam 326 .

biegsamkeit 303 .

biene rog, $3^{87}$.

bier 136 .

bieten 18(OHG.), 47 (OHG.), 57(OHG.), ${ }_{67}$ (OHG.), 68(OHG.), 8o(MHG.), 84(MHG.), I14, 122, 136, 18r, I85, I86(OHG.), 218 (OHG.), $267, \quad 47 \mathrm{I}$ (OHG.), 478, 480 

$\begin{array}{lll}\text { (OHG.), } & 483, & 484 \\ \text { (OHG.), } & 485, & 488,\end{array}$ 495.

bild $95,174,275,364$. bilden 274,330 .

bildner 302 .

bildung 312 .

billig 289.

binde 298 .

binden I2(OHG.), 55

(OHG.), 57(OHG.), 59(OHG.), 68(OHG.), 79(MHG.),80(M HG.),

95, 97, I62(OHG.), I8I, 185, 186, OHG.), IgI(OHG.), I95 (OHG.), 218 (OHG.), 226(MHG.), 227, 247, $253,268,478,479$ (OHG.), 483(OHG.), $484,485,496$.

bindfaden 313 .

binse $264,346$.

binsicht 304 .

birne 387 .

birschen 294 .

bis 263 .

bisam 184 .

bisschen 300 .

bissen 383 .

bissig 322.

bisweilen $55^{\circ}$.

bitte II 5, 367.

bitten I 7, 95, II 4 , $18 \mathrm{r}, 218$ (OHG.), 223 (OHG.), 224 (MHG.), 239(M HG.), 253, 267, $340,485,510$.

bitter 20 (MHG.), 172

(MHG.), 214(OHG.),

$245,260,327$.

bitterkeit 303 .

bitterlich 172 (MHG.).

blähen 120, 280.

blank 406.

blasen $136,5^{15}$.

blass 406 .

blatt $\mathrm{II}_{5}, 224,253,27 \mathrm{O}$, $357,398$.

blatter I I9, 139.

blättern 330 , 340 .

blau II7, 233,
(OHG.), 237, 400|brandmarken 330.

(OHG.). $\quad$ brandung 312.

bläuen 127, 493. braten 117, 136, 383, 483,515 .

blechern 319.

blei 125 .

bleiben 109, 125, 181, $332,485,488,490$.

bleich 130.

bleichen 482, 492 .

bleiern 3 I9.

blendling 306.

blicken 286 .

blind I62(OHG.), 168

(OHG.), I 70 (MHG.),

I 7 I(M HG. ), 244, 268, 3 I6, 399(OHG.), 401, 404.

blindlings 550 .

blinkern 340 .

blitz I 74, 386.

blitzschnell 328 .

blöde 123, 174 .

blondhaarig 328 .

bloss 122.

blühen 73 (OHG.), I38, 242, 280.

blume $137,346,3^{87}$.

blut $137,270$.

blutarm 26,328 .

blüte 138,377 .

blutig 322 .

blutjung 26,328 .

bock 79(MHG.), 96, 202

(OHG.), 286.

boden IIo, I72(MHG.), 246.

bogen I 10, I 74, 383 .

bohne 122 .

bolzen 352,383 .

bord 349 .

bơrse IOI, 104, II2, 294.

borste 294 .

böse 123, I74, 547 .

boshaft 320.

bote II5, I 70 (MHG.), I 74, 185, 267, 298, $3^{82}$.

botschaft 3 10, 376 .

bottich 115 .

236 bracke $174,3^{82}$. brauchbar 3 I8.

brauchbarkeit 303 .

brauchen $126,255$.

brauen 126, 493.

brauerei 28 .

braun 126, 399(OHG.).

braut 79(MHG.), I26, 375.

bräutigam $127,174,184$, 386.

brav 406.

breche 298.

brechen 94, 120, 255, $288,485,504$.

brei, 174, 386 .

breit I30.

breite 299, 372.

brennen 16,60 (OHG.), 79(MHG.),80 (MHG.), 92, 164 (OHG.), 223 (OHG.), 239, 245, 247, 268, 531, 532.

brenner 302.

brief $7 \mathrm{x}$ (OHG.), 83 (MHG.), 136, 226 (MHG.), 253, 258, 374(MHG.).

bringen 69(OHG.), II9, 120, 139, 200 (OHG.), 250, 28I, 488 (OHG.), $496,53 \mathrm{I}$.

brocken 383 .

brodem II8.

brombeere I18, 139.

brosam 184 .

brot I22, I 74, 270, 356.

bruch 298.

brücke 79(MHG.), 99, I05, 223, 29I, 370 .

bruder 87 (MHG.), 137, I92(OHG.), 195 (OHG.), 225(OHG.), 253, 274, 299, 394 (OHG.), 396.

brüderschaft 3 то. braue II $7,233,37$ I.

brett II 5, 224, 357 . 
brühe 138 .

brüllen 138 .

brunft 246.

brunnen $97,174,3^{8} 3$.

brust $97,392$.

bube $137,174,382$.

buch 22, 79 (MHG.), 137, 138, 288, 298, $392,398$.

buchbinder 3 r 3 .

büchelchen 300 .

buchstabe 384 .

buchstabieren $34 \mathrm{I}$.

bucht 299.

buckel 349.

bude 137 .

bug 137.

buhle 174 .

bühne 113,174 .

bund $185,298$.

bundesrat 3 I4.

bündnis 308 .

bunt 406 .

bürde 274.

burg 79(MHG.), 97, I73 (MHG.), 292, 298, 392.

bürge I 74, 382 .

bursche 294 .

bürste 99, 294.

busen 246.

busse $4 \mathrm{co}$.

bütte II 5 .

büttel I 14,185 .

butter II 4,224 .

buttern 340 .

-chen 300, 356.

christ 353 .

christenheit 303 .

christentum 3 I I.

cousine 28.

da 245 .

da:h 274, 357, 398.

dachs 282, 298.

damals $27,550$.

damast 272.

dambrett 139.

damm 266.

dämmern I 14 .

dämmerung $94,3^{12}$. dampf 266 .

dank $177,250$.

dankbar $3^{18}$.

dankbarkeit 303 .

danken 250, 528 .

dann 4 .

dar 103.

daran 103, 139.

daraus 139 .

darin 245.

das I6I(OHG.), 220 (MHG.), 224, 263,

274.

dauerhaft 320 .

dauern 266.

daumen 126,383 .

däumling 306 .

dechant 272.

deckel 175.

decken 274, 286.

degen 8o(MHG.), 75 .

dehnen $107,239$.

deihen 55(OHG.).

dein 125, 247,

(OHG.), 445(OHG.).

deiner (dein) 433.

deinethalben $248,272$.

deinetwegen 248, 272.

deinige 447 .

demut 136 .

denen 449,454 .

denkbar 318.

denken I3(OHG.) (OH

(OHG.), 69(OHG.), 8I(MHG.), 92, II9, I20, 139, I 75, 204 (OHG.), 250, 28I, 286,53 I.

denn 4 .

der 103, 108, I7I (MHG.), 449.

derart 550 .

deren $449,454$.

derer 449,454 .

dergestalt $55^{\circ}$.

derselbe 462 .

derzeit $55^{\circ}$.

dessen 449,454 .

desto $45^{2}$.

deswegen $55^{\circ}$.

deuten 127 .

deutlich 324. (deutsch 77(OHG.), 127, $274,287,323$.

dich 433, 434 (OHG.).

dicht 139,174 .

dichten 28, 266.

dichterisch 323 .

dichtigkeit 303 .

dick 228.

dicke 299.

dickicht 272, 304 .

dieb 136, 253, 274,

349.

diebstahl 298.

dienen $136,268,528$.

dienerschaft 3 ro.

dienst 174 .

dienstbar 318 .

dienstmann $3^{\text {r } 3}$.

dieser I09, 17 I (MHG.), $455,456-60$.

diesseit $55^{\circ}$.

diesseits 27, 550 .

Dietrich 172 (MHG.).

dill 266.

dille 346 .

ding 250(MHG.), 356 .

dingen 496.

dir I03, I6r, 433 .

dirne $136,139$.

disputieren 28 .

disseits 139.

distel 346 .

doch 22, 96, 284 .

docht I I8, I39, 274.

docke 266 .

dogge 291.

dohle $118,266$.

dolde 266 .

donner II4, 224, 299.

doppelt 272, 424 .

dorf 79 (MHG.), 96, 98, 245,25 I, 274, 298, $393,398$.

dorn $96,274,35^{1}, 379$.

dornicht 272, 304 .

dorren 57.

dorsche 294 .

dortig 322.

dotter I I 4, 266, 386 .

drache 174,215 (OHG.), $266,382$.

draht II 7, I20, 280. 
drang 298. drangsal 309,346 . dräuen 132 . drechseln 139. drechsler 139. drehen 120, 242, 280. drei 55(OHG.), 125, I92(OHG.), 274, 316, $4 \mathrm{I} 3,420$. dreierlei 426. dreifach 424 . dreifältig 424 . dreiheit 303 . dreimal 425 . dreissig 263,4 r3. dreissigste 422 . dreizehn 413 . dreizehnte 422. dreschen 80 (MHG.), I8I, 274, 287, 502 dringen $245,485,496$. dringlich 324 . dritte 274,422 . dritt(e)halb 427 . drittens $430,55^{\circ}$. druck 349. drucken Ioo. drücken 79 (MHG.), Ioo, 286.

drücker 302. drücksen 343 . drüse 138 . du 4, r92(OHG.), 433, 434 .

ducken I00, 266. duft 266.

duften 330 .

dulden roo, 269, 274.

duldsamkeit 303 .

dumm 97, 256, 266, 406. dummerweise $55^{\circ}$.

dummheit 303. dümmling 306 . dumpf 406 . dung 266. dunkel 266, 327. dünken 57(OHG.), 74 (OHG.), 79(MHG.), 8I(MHG.), 99, 53I. dünn 79(MHG.), 99, I 74, 202(OHG.), 400, 406 , dunst 266 .

durch 284 . durchgehends 550 . durchsichtig 328 . dürfen 534, 537 . dürftig $99,3^{22}$. dürftigkeit $3 \circ 3$. dürr $57,99, \mathbf{I} 74$. durst 294 . dutzend 266, 272. duzen 343 .

eben 108, 165(OHG.), I 72 (MHG.), 253, 547 . ebenfalls $55^{\circ}$. ebenheit 303 . eber 108, 175 . ebnen 330 .

echt I2 I, I39, 259.

ecke 29I, 346. edel 90, 107, 179, 244, $306,327$. edeling $172($ MHG.), зо6. ehe 174,245 .

eher 75(OHG.), 12 I, 245, 549. ehre 8I(MHG.), I2I, 367.

ehrlichkeit 303 .

ehrlos 325 .

-ei 30 r.

ei I3०, $24 \mathrm{I}$ (OHG.), 398.

eiche 130, 298, 39 r.

eichen 319.

eid 130 .

eidam $184,246$.

eidechse 290.

eierhändler 3 r 4 .

eigen 130,327 .

eigenartig 328 .

eigenhändig 26 .

eigennutz 352 .

eigenschaft 3 ro.

eigentlich 272.

eigentum $3 \mathrm{I}$ I.

eigentümer 302 .

eigentümlich 26 .

eiland 248.

eilen 125 .

eilends 550 .

eimer 247, 256. ein 44(OHG.), זз०, 418, 469.

einbildung 312 .

einerlei 426.

einerseits $55^{\circ}$.

einfach 424 .

einfältig 424 .

einheit 303 .

einheitlich 324 .

einig 292, 322 .

einige 469 .

einigermassen 550 .

einigkeit 303 .

einleitung $3^{12}$.

einmal 425 .

einnahme 3 I 3 .

eins 413,425 .

einsam 326 .

einschiebsel 309 .

einst 272, 550 .

einstimmig 328 .

einstweilen $55^{\circ}$.

einwandfrei 328 .

einzeln 182.

einzelnen 182 .

eis 125 .

eisbrecher 302 .

eisen 125.

eitel I25, 327 .

eiter 130 .

ekelig 289.

-el $327,340$.

elend $I_{74}$.

elf $r_{30}, r_{39}, 248,258$, $4 \mathrm{I} 3$.

elfte 422 .

elle 367 .

elster I30, I39, 290.

eltern 90, 93, 182, 269.

empfang 299.

empfangen 247,333 .

empfängnis 308 .

empfehlen I08, 247, 333, $485,499$.

empfinden 247, 333 .

empfindlich $3^{17}, 3^{24}$.

empor I03, 247.

emsig 264.

-en 3I9, 327 .

ende $92,174,364$.

endigen $34^{2}$.

endlos 325 . 
eng 92, I74, 195(OHG.), 400,405 (OHG.), 408 (OHG.), 547.

engel 92, I 7 I(MHG.), I75.

Engländerin 305. englisch 323.

ent- 333 . entbehren 247, 506. entbieten 333 . entbinden 333 . entblättern 333 . entblühen 333 . entbrennen 333 . entdecken 333 . ente 92, 377 . entehren 333 . enterben 333 . entfallen 247, 333 . entfalten, 333 . entfärben 333 . entfernen 333 . entfesseln 333 . entflammen 333 . entfliehen 333 . entfremden 247, 333 . entgegen 272. entgehen 333 . entgeistern 333 . entgelt $26,299$. entgelten 26,333 . enthalten 333 . enthaltsam $3^{17}, 326$. entheiligen 333 . enthüllen 333 . entkräften 333 . entlassen 333 . entledigen 333 . entleeren 333 . entmannen 333 . entmutigen 333 . entnehmen $333,448$. entnerven 333 . entrinnen 497 . entsagen 333 . entschädigen 333 . entschlafen 333 . entschliessen 333 . entschlummern 333 . entschuldigen 333 . entsiegeln 333 . entsprechen 26,333 . entsprechung 26 . entspringen 333 . entstehen 333 . entstellen 333 . enttäuschen 333 . entvölkern 333. entwaffnen 333 . entwürdigen 333 . entziehen 333. entzünden 333 . entzwei 272. epheu 132. eppich 243. -er I 72, 302, 319, 327, 340.

er- 334 .

er I03, I6I, 437, $43^{8}$ (OHG.).

erarbeiten 334 . erbauen 334 . erbe 92, I 74, 253, 382 . erbeben 334 . erben $33^{\circ}$. erbin 305 . erbittern 334 . erbleichen 492. erblinden 334 . erblühen 334 . erbosen 293. erbrechen 334 . erbse $235,264,377$. erde 55(OHG.), 104, 274, 367.

erdenken 334 . erdensohn 3 I4. erdulden 334 . -erei 301. ereignen 134 . ereignis 134,308 . ereilen 334 . erfechten 334 . erfinden 488. erfinderisch 323 . erfindsam 317,326 . erforschen 334 . erfragen 334 . erfreulich 3 I 7, 324 . erfrieren 334 . erfrischen 334 . erfüllen 334 . ergänzen 334 . ergebenheit 303 . ergiebig $317,322$.

ergiessen 334 .

erglänzen 334 .

ergötzen 80, 92.

ergrauen 334 .

ergreifen 334 .

ergrimmen 497 .

erhandeln 334 .

erheitern 334 .

erhoffen 334 .

erhöhen 334 .

erholen 334.

erhören 334 .

erinnern 334 .

erjagen 334 .

erkalten 334 .

erkälten 334 .

erkämpfen 334 .

erkenntnis, 308,346 .

erklären 334 .

erklärlich 324 .

erklimmen 334 .

erkranken 334 .

erlahmen 334 .

erlass 299.

erlauben

I33.

erlaubnis 308.

erleben 334 .

erledigen 334 .

erleiden 334 .

erliegen 334 .

erlöschen 92, 334, 502.

ermatten 334 .

ermessen 334 .

ermöglichen 334 .

ermorden 334 .

ermüden 334 .

ermutigen $334,342$.

-ern 3 I9.

erneuen 334 .

ernsthaft 320 .

eröffnen 334 .

erörtern 340.

erquicken 334 .

erraten 334.

erreichbar 317,318 .

errichten 334 .

erröten 334 .

ersaufen 334.

ersäufen 132 .

erscheinen 334. 
erschlaften 334 . erschlagen 334 . erschleichen 334 . erschliessen 334 . erschrecken 334,504 . erschüttern 340 . erschweren 334 . ersehen 334. crsetzen 334 . ersinnen 334 . ersitzen 334 . ersparnis 308 . erstarken 334 . erstarren 334 . erstaunen 334 . erste 412, 422. erstehen 334 . ersteigen 334 . erstens 430 , $55^{\circ}$. ersterben 334 . ersuchen 334 . erteilen 25,334 . ertrag 26, 299. ertragen 26,334 . erträglich $3^{I} 7,3^{2} 4$. erträgnis 308 . ertränken 334 . erträumen 334 . ertrinken 334 . erübrigen 334 . erwachsen 334 . erwägen 508. erwähnell 107, 279. erwarmen 334. erwarten 334 . erweitern 340 . erwerb 299. erwerben 334 . erwirken 334 . erz- 299.

erz 174,363 . erzählen ro7. erzamt 299. erzbisch of 299. erzdieb 299. erzdumm 317 . erzdummkopf 299. erzeigen 334 . erzfaul 317. erzfeind 299. erzherzog 299. erziehen 334 . erzieher 302. erzkämmerer 299. erzschelm 299. es 220 (MHG.), 224, 263, 437. es (gen.) 440. esche 346 . esel 349. essig 289. essen $\mathrm{I}_{3}(\mathrm{OHG}$.), 32 (OHG.), 38(OHG.), 6I(OHG.), 80(M HG.), 94, 105, II7, 120, I8I, I93(OHG.), 217 (OHG.), 223(OHG.), 263,47 r(OHG.), 485 , 509.

etlich 469 .

etwas 469 .

etwelcher 469 .

euch I27, 433, 434

(OHG.).

euer I70(MHG.), 234, eurer(433), 434 (OHG.), 445(OHG.). eule 127,387 . eurethalben $248,272$. euretwegen 248, 272. euter 127.

ewig I2I, 23I, 292.

ewigkeit 303 .

ewiglich 548 .

fabelhaft 320 .

fächeln 340 .

fackel 368 (MHG.).

faden I7I(MHG.), 246, 350.

fähig 322.

fähigkeit 303 .

fahl I06, I 7 I (MHG.), 235,236 (OHG.), 400 . fähndrich 273 .

fahne 346 .

fahren I3(OHG.), 59 (OHG.),6o (OHG.), 73 (OHG.), 80(MHG.), 87(MHG.), 106, 107, I 7 I (MHG.) , I8I, I85, I86(OHG.), 245, 258, 28o, 478, 484(OHG.), $485,5 \mathrm{II}$. fahrerei 301.

fahrt I3(OHG.), 90, I04, $185,269,299,376,377$.

fährte 377 .

falb 235 .

falke r 74,382 .

fall 298,374 .

fallen $1_{36}$, I94(OHG.), $258,485,5$ I 4 .

fällen $53 \mathrm{I}$.

falsch 406 .

fälschen 330 .

fälschlich 548 .

fälteln 340 .

falten 514 .

fang 298.

fangen 54(OHG.), 69 (OHG.), 8I (MHG.), 83(MHG.), I36, 139, 204(OHG.), 221 (OHG.), 5 I5.

farbe 235, $37 \mathrm{I}$.

färben $93,330$.

farre (farr), I 74, 223

(OHG.), 382.

färse 90.

fass 162 (OHG.), 224, 263,356 (OHG.), 357 . fast $90,9 \mathrm{I}, 547,549$ (OHG.).

fasten 528 .

faul 4 I(OHG.), I26, 406. fäule 127 .

faulen 528 .

faust I26, 249, 282 .

fechten 94, 96, 281, 483, 485,502 .

feder 175,368 (MHG.).

fehde 279.

fehlerhaft 320 .

feier $128,174,368$.

feigling 306.

feile 279 .

feind 125, I72(MHG.), $268,397$.

feindin 305 .

feindschaft 3 Io.

feindselig 328 .

feinschmecker $3^{1} 3$.

feist 264 .

feld $55,94,228,244$, 275 (MHG.), 357. 
fell 32(OHG.), 173, 223 fleischer 302. (OHG.), 224, 298, 356. fels 80 (MHG.), 1 74, 354 . felsen 354 .

fenster $17 \mathrm{I}$ (MHG.).

ferge $174,240,3^{82}$.

fernsprecher 302 .

ferse $90,94,294,369$.

fertig $90,9^{2}, 3^{22}$.

fertigkeit 303 .

fesseln 330, 340 .

fest $90,92,174,243$ (OHG.), 316,547 .

festung 312 .

feucht 127,174 .

feuchtigkeit 303 .

feuer $128,258,356$.

feuern 340 .

feuersnot $3 \mathrm{I} 4$.

fichte 136,139 .

fieber 7 I(OHG.), 136.

fiedler 302.

findbar 318 .

finden . 91, 95, 97, I $7 \mathrm{I}$ (MHG.), I73(MHG.), 22 (OHG.) 247,274 , $48 \mathrm{r}, 485,488$.

finder 302 .

findling 102.

finger 250,349 .

fink(e) I 74, $3^{82}$.

finsternis 172 (MHG.), $183,308$.

fisch ${ }_{13}(\mathrm{OHG}$.),

(OHG.), 66(OHG.), 80(MHG.), 95, I92 (OHG.), 287, 298, 349.

fischer 174 (MHG.), 3०2, 362.

fischerei зот.

fittich 289 .

fittig 289 .

flach 406.

flachheit 303 .

flachs 282 .

flächsern 3 I9.

flagge $29 \mathrm{r}$.

flaschner 302.

flechten $483,485,502$.

flecken 383 .

flehentlich 272 .

fleisch 130, 258, 287 .

flucht 299. fleiss 263 .

fliege 298.

fliegen Iro, 136, 290, 485,493 .

fliehen 122, 136, 493, 495.

fliessen 122, 136, 139, $185,485,495$.

flimmern 340 .

floh $122,284,346$.

floss 122, 139 .

flötz 92, 174 .

fluchen 137 .

flüchten 330 .

flüchtling 306 .

flug III, I I $3,298$.

flügel 1 I3.

flügeln 340.

flügge 291 .

flugs $55^{\circ}$.

fluss $185,298,374$.

flüssig 99 .

flüstern 95 .

flut 73(OHG.), 87 (MHG.), I37, I62 (OHG.), 376, $3^{8}$ I.

fohlen 383 .

föhre 283 .

folgen $290,528$.

folgendermassen $55^{\circ}$.

folgern 340.

folglich 324 .

fordern 274,528 .

forderung 174,183 .

forelle 24,283 .

form 174 .

förster 302.

fracht 337 .

frage 367 .

fragen II $7,290,5 I I$, 528.

fraglich 324 .

frau 79 (MHG.), 13I, 17 I (MHG.), $2 \mathrm{r} 3$ (OHG.), 232(OHG.), 234, 387, 400 (OHG.).

frauenfuss 314.

frauensperson $3 \mathrm{I} 4$.

fräulein $\mathrm{I}_{32}, 183,307$, 360. frei $125,316$.

freigebig 328 .

freiheit 303 .

freiheitsliebe 314 .

freilich 548 .

freiwillig 26 .

fremd $92,174,246$.

fremdling 306.

fressen $337,488,509$.

freude 132 .

freuen 79 (MHG.), I8I, 232 (OHG.), 234.

freund $127,173(\mathrm{MHG}$.), $245,258,268,397$.

freundin 7 72(MHG.), 305, 370.

freundlich 183,324 .

freundlichkeit 376 .

freundschaft 3 ro.

freundschaftlich 324 .

frevel 79 (MHG.), 258, 346.

frevelhaft 320 .

freventlich 272 .

friede $18, \quad 109, \quad 168$ (OHG.), 379, 384 .

friedensbrecher $3^{1} 4$.

friedlich $\mathrm{I} 74$.

Friedrich 183 .

frieren 122, 136, 221 (OHG.), 48r, 495.

frist 376 .

froh 122, 182, 236 (OHG.), 280, $3 \mathrm{I} 6$, $400,406$.

fröhlich 548 .

frohlocken 330.

fromm 8o(MHG.), 97, 224, 406.

frömmling 306 .

frosch 350 .

frösteln 340.

frucht 97,375 .

fruchtbar $184,255$.

fruchttragend 328 .

früh $138,{ }_{74}, 280$.

frühling зо6.

frühstücken $33 \circ$.

fuchs $282,295,298,350$.

fuder 137.

fügen 138 .

fühlbar 3 r 8 . 
fahlen 138 .

fuhre 298 .

führen 79 (MHG.), I38, 302.

fuhrmann $3^{1} 3$.

fuhrt 185 .

fülle $57,99,258,299$, 372.

füllen 18 (MHG.), 20 (MHG.), 99, 330, 53 I. füllsel 309 .

fund 298 .

fünf 2(OHG.), 95, I62 (OHG.), I98(OHG.), 246,4 !3.

fünfte $268,274,422$.

fünfzehn $4 \mathbf{I} 3$.

fünfzehnte 422 .

fünfzig 4 I 3 .

fünfzigste 422 .

funke(n) 384 .

funkeln 340 .

für- 299.

für $57, \mathrm{II}_{3}, 25^{8}$.

fürbitte 299.

furche 284,377 .

furcht 174 .

furchtbarkeit 303 .

fürchten 99, 167(OHG.), 258, 28I, $53 \mathrm{r}$.

furchtsam $3^{26}$.

fürsorge 299 .

fürst $99,174,346,3^{82}$, 412.

fürstenschloss $3^{1} 4$.

fürstin 305 .

furt 376 .

fürwahr $55 \mathrm{I}$.

fuss 73 (OHG.), 79 (MHG.), 87(MHG.), I37, 138, I77, I92 (OHG.), 263, 298, 389.

futter $137, x_{39}, 299$.

futtern 330,340 .

füttern 340 .

gabe II $7,185,298,367$. gadem 246 .

gaden 246.

gähnen ro8.

gähren 108. galant 406. galgen ${ }_{74}, 383$.

gang 298 , 350 .

gangbar 318.

gans 2(OHG.), 295, 39I.

gänsebraten 314,391 .

ganz 262, 469 .

gänzlich 324 .

gar IO3, 167 (OHG.),

I 7 I(MHG.),

(OHG.), 400, 550.

garbe 371 .

gären $238,508$.

garstig 294.

garten $174,269,3^{8} 3$.

gärtner I 72(MHG.), I 74, 302.

gasse 263,387 .

gast 12(OHG.), 21, 34

(OHG.), 59(OHG.), 6o(OHG.),

(MHG.), 80 (MHG.), 90, 91, 92, 16I (OHG.), I62(OHG.), I 70 (MHG.), 2 II (OHG.), 218 (OHG.), 290, 295, 344(OHG.), 373.

gastieren $34 \mathrm{I}$.

gäten 238,507 .

gatte $115,1_{74}, 3^{82}$.

gatter II 4 .

gattin 305,370 .

gau I3I, 232(MHG.), 346.

gaukelei 301.

ge- 26, 299, 335, 488. gebärde I20, I 74

(MHG.), 185 .

gebären 12(OHG.), I3

(OHG.), 21, 32 (OHG.), 55(OHG.), 67(OHG.), 70 (OHG.), 8o(MHG.), 8I(MHG.), 90, 108, I09, I Iо, I6r(OHG.), I62(OHG.), I7I (MHG.), 185, 195 (OHG.), I99(OHG.), 206(OHG.), 218 (OHG.), 335, 485, 503. gebăude $26,174,363$.

gebein 174 .

geben 55, 59(OHG.), 62(OHG.), 80 (MHG.), 89, 108, 109, II $7,120,186$ (OHG.), 200 (OHG.), 218 (OHG.), 225(OHG.), $226(M H G), 227,$.253 , $290,478,483,484$ (OHG.), 507.

gebet II $5,255,356$.

gebiet 174,363 .

gebieten 335 .

gebilde ${ }_{74}, 3^{6} 3$.

gebinde 174 .

gebirge 26,55, I 74, 299, 363.

gebiss 299.

gebot 26, II5, 185 .

gebrauch 299.

gebrauchen 288, 335 .

gebrechen 335 .

gebuhr II3.

gebühren I 13, 335 .

gebührlich 317,324 .

gebundenheit 303 .

geburt 104, 185, 269, 299; 376 .

gebürtig 322.

geburtstag 314.

gebüsch 1 74, 299.

gedächtnis 308 .

gedanke $35^{2}, 384$.

gedeihen 55 (OHG.),

125, 186;OHG.), 279,

$335,48 \mathrm{r}, 49 \mathrm{r}$.

gedeihlich 317,324 .

gedenken 335 .

gedicht 174,363 .

gediegen 290, $49 \mathrm{I}$.

gedrang 92.

gedränge $\mathrm{r}_{74}, 299$.

geduld 26, 97, 269.

geduldig 79 (MHG.), roo, 269.

gefahr 117 .

gefährlich 324 .

gefährt 174 .

gefährte ro4, r 74, $3^{82}$.

gefährtin 305 .

gefallen 335 . 
gefällig $3^{x} 7,3^{22}$. gefangene $\mathrm{r} 7 \mathrm{I}(\mathrm{MHG}$.). gefängnis 308,346 . gefäss $120,299,363$. gefecht I 74, 299. gefilde $55,1_{74}, 299$, збз. geflecht 299. geflissentlich 272 . geflügel 299. geflügelt $3^{1} 7$. gefolge 174 . gefrieren 335 . gegenfüssler 302 .

gehalt 299.

gehänge $x 74$.

gehege 107 .

geheimnis 308 .

gehen $7 \mathrm{r}(\mathrm{OHG}),. \quad 8_{3}$ (MHG.), I36, т39, I8I, 280, 485, 51 4 , 544.

geheuer 128 .

gehirn I74.

gehoft I 74 .

gehölz I 74, 299.

gehorchen 335 .

gehören 335 .

gehorsam 326.

geier I 28.

geige $3^{87}$.

geil 130 .

geiss 376 .

geist r3o, 26o, 351 .

geisteskrank 328 .

geistlich 548 .

gelächter 299.

gelände $\mathrm{r} 74,299,3^{6} 3$.

gelangen 335 .

gelaunt 3 I 7 .

geläut 299.

gelb 94, 235.

geld 269, 357.

gelegentlich 272,324 .

gelehrtheit 303 .

geleise 174 .

geleit 174 .

geleiten 335 .

gelinde 174 .

gelingen $335,485,496$.

gellen 5or.

geloben 57,335 .

gelten 94, I7 I(MHG.),
I8r, $269, \quad 483,485$, 498.

geltung 3 ra.

gelübde $57,99,18_{5}$.

gelüst 174 .

gemahl I 74, 279, $3^{86}$.

gemahlen $5 \mathrm{I}$.

gemahlin 305,370 .

gemäss 174,363 .

gemein $130,{ }_{74}$.

gemeinsam 326 .

gemeinschaft 3 ro.

gemengsel 309 .

gemisch 299.

gemse 264,377 .

gemüse 174,363 .

gemüt 174,364 .

genau 182 .

genehm 174 .

genehmigen $34^{2}$.

genesen I08, 221

(OHG.), 335, 48I,

507.

genesung $3^{12}$.

geniessen 122, 136, 139,

$335,495$.

genosse 1 22, r 39,263 , 389.

genug I37, r39, 550 .

genügen 138 .

genügsam 326 .

genuss 299.

gepäck I 74, 299.

gepräge I 74, 299.

ger $12 \mathrm{r}$.

gerade 174,335 (MHG.).

gerät $\mathrm{r} 20, \mathrm{I} 74$.

geraten 335 .

geräusch 174 .

gerben 235 .

gereichen 335 .

gereuen 335 .

gericht 55 .

gerichtsamt $3^{1} 4$.

gering $\mathrm{I} 74$.

gerinnen 335 .

gerippe $\mathrm{r} 74$.

gern 549.

gerochen 506.

gerste 294.

gerstenmehl 3 I 4 .

geruch 299. gerücht $x_{38}, 1_{39}, 259$.

geruhen 288 .

gerüst I 74, 299.

gesalzen $5 \mathrm{I}_{4}$.

gesamt 469.

gesandtschaft $27 \mathrm{r}$.

gesang 299.

geschäft $x 74,36_{3}$.

geschehen ro8, 335,

507.

gescheit I 74 .

geschenk 174,363 .

geschichte 377 .

geschirr 1 74, 299.

geschlecht 79 (MHG.),

$93,174,364$.

geschöpf 92.

geschrei I 74, 299.

geschreibsel $3 \circ 9$.

geschwind 275 .

geschwister 299.

gesegnen 335 .

geselle $92, \quad$ 74, 382,

$3^{89}$.

gesellschaft 3 ro.

gesetz 174,363 .

gesetzmässig 328 .

gesicht 26, 28I, 299,

357.

gesims 264 .

gesinde 174,363 .

gespann 174 .

gespenst 92, r 74, 35 r.

gespräch 299.

gestade 274 .

gestalt 376 .

gestatten I 4 , 335 .

gestehen 335 .

gestein 299.

gestern 80 (MHG.).

gestirn 174,363 .

gesträuch 127.

gesund 406.

gesundheit 303 .

getrauen 335 .

getreide 26, I74, 290, 363.

getrösten 335 .

gevatter II $4,3^{85}$.

gewächs 174,363 .

gewahr ro3.

gewähren 108, 335 . 
gewalt 26, 269, 299, 346, 376.

gewand 358.

gewandtheit 27I, 303 .

gewarten 335 .

gewässer 299.

gewebe 174 .

gewerbe 174 .

gewesen 108, 507.

gewicht 95, 174, 363 .

gewinn 299.

gewinnen 97, 101, 335, 485,497 .

gewiss 185 .

gewissen 346.

gewissenhaft 320 .

gewissermassen 550.

gewitter 55, II4.

gewohnen 92, $112,335$.

gewohnheitsmässig 328 .

gewohnt 272.

gewolbe 92, 174.

gewolke 363 .

gewürm 299.

geziemen 335 .

giessen $76(\mathrm{OHG}$.), 122, 136, 139, 495.

giesskanne $3^{1} 3$.

gift $55,95,200$ 'OHG.), 346.

gimpel ro2.

gischen 296.

gischt 238, 296.

gitter II4.

glas I9(MHG.), 89, 106, 2̧̧o, 357.

gläsern 319.

glasieren $34 \mathrm{I}$.

glatt II5, 290, 406.

glaube I3I, 384 .

glauben 19 (MHG.), 79 (M HG.), 133 (MHG.), I85, 226(MHG.), 227, 253,335 .

gläubig ${ }^{32}, 322$.

glaublich 324 .

gleich 125, 162(OHG.), 228, 469, 547 .

gleichen 492.

gleicherweise 550 .

gleichfalls 550 .

gleichnis 308 . gleichsam 326 .

gleissen 492.

gleiten II 4, 492.

glied rog.

gliedern 340.

glimmen 485,497 .

glitzern 340 .

glocke 387 .

glöckner 302.

glück 174 .

glücklich 324

glücklicherweise 550 .

glückselig 328.

glückskind 174 .

glühen ${ }^{3} 8$.

glut 376 .

gnade 117,174 .

gnädig 292, 322, 549 .

gold 57,68 (OHG.), 96, 225 (OHG.), 275, 319. golden 3 I 9.

gönnen 8o(MHG.), Ior, 537.

gott I2(OHG.),

(OHG.) 67(OHG.)

79(MHG.), 80

(MHG.), II5, 224,

270, 290, 35I.

gotteshaus 174 .

gottheit 303 .

göttin 79(MHG.), 98.

gottlos 325 .

gottlosigkeit 303 .

grab 89, 106, 245, 253, $298,357$.

graben 79(MHG.), 106, 107, 137, 290, 383, 485,5 II.

graf ${ }_{11} 7, x_{74}, 3^{82}$.

gräfin I20, 305 .

gram 106.

grämen 107.

granne 174 .

gras 89 , 106, 290, 295, $298,357$.

grat 373 .

gräte 346.

grau II $7,233,236,316$, $400(\mathrm{OHG}$ ), 406.

gräuel 126.

graugelb 328 .

grausam 326. grausamkeit 303 .

greifen 125, 224, 258, $485,492$.

greinen 490.

greuel ra7.

griff 298.

grille 346 .

grimm 223(OHG.).

grimmen 497.

grimmig 322.

grob 89, I I

(MHG.), 406.

groschen 296.

gross I22, I 7 I (MHG.),

I 74(MHG.), I82, 406.

grossartig 328 .

grossheit 303 .

grossmuatig 26.

grossmutter 26.

grösstenteils 550.

grossvater 3 I3.

grube $137,298$.

grün 79 (MHG.), 138,

I 74 .

gründling 306.

grundlos 325 .

grundschlecht 328 .

grunzen 343.

gruss 137 .

grüssen 18 (MHG.), 220

(MHG.), 263.

grütze 346 .

gulden 57, 68(OHG.),

100.

gülden 100.

gultig 99, 322 .

gurt 349 .

gürten 99, 269.

gut $\mathrm{I}_{3}(\mathrm{OHG}),. \mathrm{r}_{37}, \mathrm{I}_{7 \mathrm{I}}$

(MHG.), 263, 290, 3I6, 4 IO 547.

güte 79(MHG.), I38,

299, 372.

gütig 322.

gutsbesitzer 29.

haar II 7, I 74, 356 .

haben $\mathrm{I}_{3}$ (OHG.), I o6, I39, I63(OHG.), I 70 (MHG.), 246(OHG.), $253,277,528,533$.

habicht 272 . 
hader 106.

hafen 350.

hafer 106, $3^{86 .}$

hafner 302 .

-haft 26, 320, 406.

haft 259.

haftbar $3^{\text {I } 8 . ~}$

hag 349 .

hagel $290,299$.

häher I08.

hahn 90, I06, 162 (OHG.), 185, 386.

hahnenfeder $3^{1} 4,386$.

hahnenschrei 386 .

haide sзo.

hain 130 .

hake 117 .

häkelig 289.

häkeln 340 .

haken 383 .

halb 253 .

halbbruder 3 r 3 .

halbieren 28, 34I.

halm $298,349$.

hals 295,350 .

haltbar 318 .

halten 60(OHG.), $7 \mathrm{I}$ (OHG.), 79(MHG.), 83(MHG.), 93, 136, I8I, 212 (OHG.), 244, $269,483,485,5$ I 4 .

hammel I 4,350 .

hammer II 4,350 .

hämmern 340 .

hamster 386 .

hand I3, 90, 9I, 228, 268, 277, 344(OHG.), $38 \mathrm{I}$ (OHG.).

handbreit $3^{28}$.

handel I 75, 299.

handeln 175 .

handhaben 330 .

händler 302 .

handlung I72(MHG.), 3 I2.

handwerker 302.

hang 298.

hangen 12;OHG.), 69 (OHG.), 136, 139, 221 (OHG.), 515 .

hängen 92.

harfe $25 \mathrm{I}$ (MHG.), $3^{87}$. harmlos 325 .

harnisch 296.

hart 9I, I82, 269, 3I6,

547.

härtigkeit 303.

harz I04.

hase 106, I 74, 221

(OHG.), 382.

hass I3(OHG.), 224, 263.

hassen $263,330,528$.

haube $\mathrm{I} 74$.

hauen 131, 136, 232

(OHG.), 234, 237

(MHG.), 518.

haufe $126,258,352,384$.

häufeln 340 .

haufen $35^{2}$.

haufenweise 550 .

häufig 322 .

haupt 76(OHG.), 79 (MHG.), 86(MHG.), I32, I33(MHG.), I 74, $253,270,357,398$.

häuptling 306 .

häuptlings $55^{\circ}$.

hauptmann 313 .

haus I2(OHG.), I8

(MHG.), 2I, 74 (OHG.), 79 (M HG.), 8 I(MHG.), I26, I27, 226(M HG. ), 295, 298, $393,398$.

hausbacken 328 .

hausfrall 29.

haushalter 302 .

haushaltung $3^{1} 3$.

hausieren 34I.

häuslein 307 .

häuslich I27.

haut 79 (OHG.), 126, 127. heben I07, I 10, I37, I63 (OHG.), I92'OHG.), $213(\mathrm{OHG}$.), $22 \mathrm{I}$ (OHG.), 239'OHG.), 243, OHG.), 48 I, 483 , $485,5^{12}$.

hecke 291 .

hecksel 309.

heer $13(\mathrm{OHG}$.), 60

(OHG.), 107, r 74, 240, 363. heft $\mathrm{I}_{74}, 363$.

heften 532 .

hehlen I08, 280.

hehr I2I.

heide I3०, I 7 I (M HG.), 353.

heil 75 (OHG.), гзо.

heilant 172 (M HG.).

heilen I $30,330$.

heilig I 72'(MHG.), 292.

heiligtum 3 I I.

heilung 3 I2.

heim I30, 246, 277.

heimat 184,346 .

heimwärts 550 .

Heinrich I 72 (MHG.).

heirat I25, 346 .

heiraten 330 .

heiratsgeschenk 3 I 4 .

heischen 277,528 .

heiss I30, I85, 263.

heissen 7 I(OHG.), 75

(OHG.), 82(M HG.), I30, 217 (OHG.), 277, 5 I6.

-heit $303,376,379$.

heiter 175 .

heiterkeit 303 .

heizen 262 .

held I $74,275,353$.

heldin 305 .

helfen I2(OHG.), 55

(OHG.), 57'OHG.), 6I(OHG.), 62(OHG.),

67(OHG.), 80

(MHG.), 91, 94, 96,

99, I62 (OHG.), I86

(OHG.), 217 (OHG.),

25I, 277, 478, 479

(OHG.), 483, 484, $485,498$.

hellfarbig 328 .

helm 6I(OHG.), 80

(MHG.).

hemd $92,174,364$.

hemmnis 308 .

henne 90,92 .

her I03.

heraus 139.

herbe 174 .

herberge $139,3^{1} 3$.

herbergen 25,330 . 
herbst I 74 .

herd 104.

herde 55, ro4, 269.

herein I03, I39.

hering 306.

hermelin 24.

herr I $\left.7 r^{\prime} M H G.\right), ~ I 74$, 382.

herrin 305.

herrlich I2I, 139.

herrschaft I2r, I39, 3 ro.

herrschen 121, 139, I 74 (MHG.), 294.

herz I3(OHG.), 94, I6r

(OHG.), I62(OHG.), I92(OHG.), 26r, 262, $277,346(\mathrm{OHG}$.), 388. herzlichkeit 303 .

herzlos 325 .

herzog r39, I 74, 221 (OHG.), 298, $3^{86 .}$

herzogin 305 .

herzogtum 3 II, 35I.

heu 79 (MHG.), I 32 , I 74, 232(MHG.).

heuchelei 301.

heucheln 127.

heuer 128, 356, $55^{\circ}$.

heulen 127.

heuschrecke 346 .

heute I27, 348, 438, 550.

hienieden 245.

hier $7 \mathrm{r}$ (OHG.),

(MHG.), 136 .

hierunter 245 .

hilfe 95, 298.

himbeere 247.

himmel II4, 224, 244, $246,349$.

himmelisch I 72 (MHG.).

hin 95 .

hindern 268.

hindernis I 72 (MHG.), $308_{m}$

hinken 496.

hinten 268 .

hinter 95, 268.

hintere $4 \mathrm{I} 2$.

hirn 174,563 .

hirsch 95, I 74, 264.

hirse $294,346$.

83 (hirt เ8 OHG.), 55, 95, I 70 (MHG.), 243 (OHG.), 346(OHG.), $36 \mathrm{r}$.

hitze $185,262,299$.

hoch I2(OHG.), I3, 76 (OHG.),79(MHG.),8 $\mathrm{I}$ (MHG.), 122, I82, 226 (MHG.), 279, 284, 372 (OHG.), 405(OHG.), 406, $408,549$.

hochfein 26.

höchlich 548.

hochmut 3 r 3 .

hochschule 3 i3.

höchstens 550.

hochwichtig 328 .

hochzeit I22, I39.

hochzeitsfest 3 I 4 .

hof I9 (MHG.), (MHG.), 89, I10, 226 (MHG.), 258, 350 .

hoffart I22, 139 .

hoffentlich 272,324 .

hoffnung 312,368 .

hoffnungslos 325 .

hoffnungsvoll $3^{28}$.

hofieren 28, 34I.

hothe I23, I63(OHG.), 279, 299, 372(OHG.).

hoheit 303 .

hohl IIo, 406.

höhnen I23, 53 r.

h7, 96, 406

holen 528.

hölle 80, 92, 370.

Holthausen 393 .

holunder 34 .

holz I3(OHG.), 96, 26r, 262.

hölzern 3 I9.

holzicht $32 \mathrm{r}$.

honig IIO, I72(MHG.), $250,292,346$.

hopfen 383 .

hopsen 343 .

hörbar $3^{18}$.

horren 79(MHG.), 123, I6 4 (OHG.),

(MHG.), 268, 277, 527.

horn $96,277,357$. hornern 319.

hornisse 24,346 .

horst $294,346$.

hose $110,3^{87}$.

hübsch $\mathrm{I}_{3}, 323$.

hüfte 272,377 .

huhn $137,1_{3} 8,{ }^{85}, 280$, 398.

huld 57,79 (MHG.), roo, I 74 .

huldigen 342 .

hülfe $95,298$.

hülle 99.

hummel 256.

hund 35 (OHG.), 97, 192

(OHG.), 268, 298,

349.

hundert 268, 4I3, 4I5.

hundertste 422 .

hündin 305 .

hüne 382 .

hunger $25^{\circ}$.

hungern 340 .

hüpfen 79 (MHG.).

hürde 377 .

hüsteln 340 .

husten I37, I74, 383 .

hut $137,1_{74}, 368$.

hüten $53 \mathrm{I}$.

hütte 370 .

-ich 289.

ich 22, I93(OHG.), 217

(OHG.), 288, 432.

-icht 304, 321, 406.

-ieren $34 \mathrm{I}, 488$.

-ig $26,172,289,320$, $322,406$.

-igen 342.

-igkeit 303.

ihm IOg, I7r(MHG.), $437,43^{8}$.

ihn 163 (OHG.), 437.

ihnen 437.

ihr I03, I68(OHG.), $433,434,446$.

ihrer 437 .

ihrethalben $248,272$.

ihretwegen 248, 272.

imbiss $26,247$.

imme 256, 346 .

immer 136, 139. 
-in 24, 172, 305, 333, 372.

in 95.

-ing 24, 172, 306.

inhaltsreich 328 .

innere $4 \mathrm{I} 2$.

innerhalb 27.

insbesondere 55r.

insgesamt $55 \mathrm{r}$.

insofern $55 \mathrm{r}$.

insoweit $55 \mathrm{r}$.

inwiefern $55 \mathrm{r}$.

inwieweit $55 \mathrm{I}$.

irden(OHG.), 55, 319.

irdisch 55,172 (MHG.), 287,323 .

irgend $272,469$.

irgends $55^{\circ}$.

irre 174 .

irrsal 309.

irrtum 311 , 35r.

-isch I 72, 323, 406.

jagd 346.

jagen 106,528 .

jäger 362 .

jägerei $30 r$.

jäh r20, I 74 .

jahr II 7, I73(MHG.), $174,238,280,356$.

jahrelang 328 .

jährlich 324 .

jammer II9, 139, 238, 346.

jämmerlich 324 .

jammerschade 3 I 3 .

jammervoll 328 .

jäten 108, I I4, 238, 507 .

jauchzen 343 .

jedenfalls $55^{\circ}$.

jeder 469.

jedermann 469 .

jederzeit 550 .

jedweder 469 .

jerlicher 469 .

jemals 550 .

jemand 272, 469 .

jener $\mathbf{r}_{3}(\mathrm{OHG}$.), $46 \mathrm{r}$.

jenige $46 \mathrm{r}$.

jenseit $55^{\circ}$.

jenseits 27, r 39,550 .

jetzt 272.
Jeweilen 550.

joch 57 (OHG.), 96, 16I

(OHG.), I62'OHG.) 193(OHG.), 238, 298, 356.

jude III, I74, 382 .

jugend III, 238,376 .

jung $97,182,23^{8}, 25^{\circ}$

(MHG.), 406, 408, 549 .

jungfrau 26.

jüngling 174,183 .

junker 174,386 .

käfer 108, 386.

käfig ro7, 243.

kahl ro6, 400, 406.

kaiser I 30, I66(OHG.).

kaisertum $3 \mathrm{I}$ r.

kalb 6o(OHG.), 80

(MHG.), 93, 217

(OHG.), 244, 253, 286, $298,398$.

kalt 9I, 193(OHG.), 212

(OHG.), 269.

kaltblütig 328 .

kälte 79(MHG.), 93, 299.

kamm 195(OHG.), 256.

kammer II 4 .

kämpe 382 .

kampf $25 \mathrm{I}$.

kapelle 28 .

karg 406.

Karl 399.

karpfen 25I.

karst 294.

karte 9I.

käse $120,36 r$.

kästchen 300 .

kasten 383 .

kater II4.

katze 262,387 .

kauen 76 (OHG.), r26, 493.

kaufen 79(MHG.), г 33, 258.

käufer 132.

käuflich 324 .

kaum I26.

kauz 262.

kebse 174 .

kehle ro8, I74. kehren rar.

kehricht 304.

kein $130,174,228,469$.

keinenfalls $55^{\circ}$.

keineswegs $55^{\circ}$.

-keit $303,376$.

kellner 302 .

kennen $268,53 \mathrm{r}$.

kerl 360 .

kern $x 74,386$.

kerze $3^{8} 7$.

kette II5, 369 .

keuchen 127.

keusch 127, 174, 400.

kiesen I3(OHG.), 76

(OHG.), 77(OHG.), 81(MHG.), 84

(MHG.), 85 (MHG.), I62(OHG.), I93

(OHG.), 2Ir(OHG.), $22 \mathrm{I}(\mathrm{OHG}),. \quad 226$

(MHG.), 495.

kind $\mathrm{I}_{73}$ (MHG.), $2 \mathrm{r} 7$

(OHG.), 226(MHG.), $227,298, \quad 357,400$ (OHG.).

kinderei 3 or.

kindererziehung $3 \mathrm{r} 4$.

kinderlos 325 .

kinderreich 328 .

kindheit 303 .

kindisch $\mathrm{I}_{72}$ (MHG.), $183,323$.

kindlein I72(MHG.), $307,356$.

kinn $r 74,202$ (OHG.), $3^{6} 3$.

kirche 387 .

kirchhof $\mathrm{I} 74$.

kirchner 302 .

kirr I 74 .

kirre 174.

kirsche 294.

kissen 102.

kitt 102, II5.

kitze 346.

klafter I I9, 139.

klage 174,367 .

klagen 106, 290, 528.

klagend 406 .

klar I I 7 .

klaue II 7, 233. 
kleben 108, 286, 528 .

klecksen 343.

klee 121, 236, 365 .

kleid I 30,357 .

klein I3(OHG.), I30, I 74, I82, 286.

kleinigkeit 303 .

kleinod 270,364 .

klieben 493 .

klimmen 97, 256, 485, 497.

klingen 496.

kloben 383 .

klopfer 302 .

kluft 299.

klug $137,316$.

knabe 174,215 (OHG.), 382.

knabenzeit, 314 .

knäblein 307 .

knapp 228, 406.

knappe I74, 2r5, 224 (MHG.), $3^{82}$.

kneifen 492.

kneten I I 4, 267, 286, 507 . knie 136, 193(OHG.), $21_{7}$ (OHG.), 236, 286. kniff 298.

knirschen 294.

knochen $174,3^{8} 3$.

knollen 383 .

knopf 57,25 r.

knoten I I 4,383 .

knüpfen 57 .

knüttel II 4.

koben 383 .

koch 350 .

kohl I22.

kohle I ro, 346.

kolben 383 .

Kölner 302.

kolossal 406.

kommen II4, 18I, 193

(OHG.), I 8 (OHG.), $224,246,478,485$, 488,505 .

könig 80(MHG.), IoI, II2, I72(MHG.), I74, 250, 286.

kőnigin I 72(M HG.), I 74, $183,305,370$.

Konigshofen $3^{1} 5,350$. kơnigssohn $3 \mathrm{I} 4$.

konigtum $3 \mathrm{Ir}, 35 \mathrm{I}$.

können Ior,223 (OHG.), $534,537$.

köpfen 330.

korn I3(OHG.), 286, 298, 357 .

kost 368 .

kostbar 3 I 8 .

kot 118 .

krach 349 .

krächzen 343 .

kraft 92, 258, 259, 260, 375 .

kräftig I 83,322 .

kragen 383 .

krähe I 74 .

krähen I20, 286.

kränkeln 340 .

krankheit 303 .

kränklich 324 .

krapfen II9, 139 .

kraut 79(OHG.), I26, 127, 357.

krebs $174,264$.

kreis 264 .

kreisen 264 .

kresse 346 .

kreuz 127, 174, 261, 262, 363 .

kreuzweise 27.

kriechen $136,493$.

krieg 136 .

kriegsmässig 328 .

krippe 257.

kritzeln 340.

kröte 1 I5.

krug 286.

krumm 97, 256.

küche 369 .

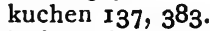

küfer 138 .

kugel III.

kuh I $37,280,286$, 39 I.

kühl I38, 174, 280, 3 I6.

kühlen 330.

kühn 138,174 .

kühulich 548 .

kümmel II 4 .

kummer 97, 256.

kund $\mathrm{I}_{3}(\mathrm{OHG}$.).

kunde 100 . künden 274.

kundig 100.

kundschaft 3 10.

kundschaften 330 .

künftig 246.

kunst I9(MHG.), 299.

künsteln 340 .

künstler 302 .

kupfer 214 (OHG.), 251.

kupfern 3 r9.

kür 375 .

kürbis 264 .

kurfürst roo.

kurz 262.

kürze 99.

kürzen 330 .

kurzerhand 550 .

kürzlich 548 .

kurzsichtig 328.

küssen 223(OHG.), 239,

295.

kutteln ( $p l$.$) I I 4$.

laben 106.

labsal 309.

lächeln 340 .

lachen $276(\mathrm{OHG}$.), 278.

lachs $282,349,373$.

laden $s b .3^{8} 3$.

laden $v$. 106, 137, 482, $483,5 \mathrm{II}$.

ladung 3 r2.

laffe 174,382 .

lager 299.

lahm I06, 280, 316, 406.

lähmen ro7.

laib 130 .

laie I $_{30}, \mathrm{I}_{74}, 3_{82}$.

lamm 79(MHG.), 90,

92,163 (OHG.), I70

(M HG.), I 7 I (MHG.),

2I8(OHG.), 226

(MHG.), 244, 256, 298, 344(OHG.), 398.

lämmlein 307 .

land $268,298,358$.

landesherr 174 .

landschaft 3 Io.

landsmann 174 .

lang 6o(OHG.), 79

(MHG.), 92, 195

(OHG.), 226(MHG.), 
250(MHG.), 316, 405 (OHG.), 408(OHG.), 547,549 .

langarmig 328 .

länge $6 \mathrm{o}(\mathrm{OHG}$.,$\quad 79$ (MHG.), 8o(MHG.), 299, 372 .

längs 178,550 .

langsam 326 .

langweilen 330.

lappen 383 .

lärche 90 .

lass 406.

lassen 70(OHG.), 136, I39, 18r, 223(OHG.), $263,478,515$.

last 299, 376 .

lästern 340 .

lästig 322.

lattich II 5 .

latwerge 240 .

lau 117 .

laub 79(MHG.), I3I.

laube I3I.

lauch I 3 I.

lauf $132,298$.

laufen 84(MHG.), 86 (MHG.), $131,132,136$, $258,278,485,5$ I 8 .

läufer 132,302 .

lauferei 301 .

läugnen ${ }^{3} 3$.

laune 126 .

laus 391 .

laut 126, 278, 547 .

lauter I7I(MHG.), 2I4 (OHG.), 223(OHG.), 327,469 .

läuten 127.

läutern 340 .

leben 56(OHG.), Iо8, I 74, I75, I8I, 218 (OHG.), 244, 268, $527,529$.

lebundig 24, 322 .

lebensart $3 \mathrm{I} 4$.

leber 56 (OHG.), 108.

leblos 325 .

lechzen 343 .

lecken 56(OHG.), 286, 528.

leder ro8. ledern 319.

leer I8(MHG.), 79 (MHG.), 120, I 74, 316, 400.

leeren 330.

leerheit $3 \circ 3$.

legen 107, I74, 239 (MHG.), 527, 529.

lehren 75(OHG.), 8I (MHG.), I2I, I85, 280.

lehrer $302,362$.

lehrhaft 320 .

lehrling 306.

leib I9!MHG.), I25, 226(MHG.), 351.

leibhaftig $3^{20}$.

leiche 377 .

leichnam I74, $3^{86}$.

leicht 125 .

leichtsinn 3 ז 3 .

leid 130 .

leiden $\mathrm{I}_{4}, \mathrm{I}_{25}, \mathrm{I} 8 \mathrm{I}, 485$, 492.

leier 128,368 .

leihen 43(OHG.), 75 (OHG.), I09, I25, I 92 (OHG.), $22 \mathrm{I}$ (OHG.), 226(MHG.), 279, 48I, 491.

leim 125.

-lein 24, 79, I 72, 307 .

Leipziger 302.

leise I 74, 249.

leisten I 30,352 .

leiten 82(MHG.), гзо, 2I2(OHG.), $22 \mathrm{I}$ (OHG.), 223 (OHG.), 53 I.

lenz I3(OHG.), I 74, $262,3^{86 .}$

- ler 302.

lerche 90, I2 I , 139.

lernen 56(OHG.), 64 (OHG.), $185,528$.

lesbar 318 .

lesbarkeit 303 .

lesen 108, 109, II 7, 120, $226,227,263,293$, $295,48 \mathrm{I}, 483,485,507$. lesenswert 328 .

leser 302. letzen 220(MHG.).

letzte 4 IO.

leuchten 77 (OHG.), 85

(MHG.), I27.

leuchter 302.

leugnen $\mathrm{I}_{32}$.

leumund 127.

leute 85 (MHG.), I27.

leutselig 328 .

-lich 24, 26, 59, 79, I 72, 289, 324, 406, 548.

licht 77 (OHG.), 84 (MHG.), 136, 139, 28I, 357 .

lieb 77 (OHG.), $\quad 84$

(MHG.), I36, I7 I

(MHG.), $185, \quad 226$ (MHG.), 253, 3I6, 549.

liebäugeln 340 .

liebe 174 .

liebeleer 328 .

liebelei zor.

liebesbrief 314.

liebling 306.

lieblosigkeit 303 .

lied 136,357 .

liegen 80 (MHG.), I08, I09, $218(\mathrm{OHG}$.), 239 (MHG.), 292, 485, 5 ro.

-ling 24, I 72, 306.

links 178,550 .

linse 293 .

lispeln 340 .

list $185,346,376$.

lob I ro, 346 .

loben IIO, I85, 227, 330, 409, 528 .

loch I8(MHG.), 22, 79 (MHG.), 96, 98, 357, 398.

locke 286,346 .

locken 286 .

löcken 92.

loffel 8o, 92.

lohn $76(\mathrm{OHG}$.), I22, $298,346,350$.

lohnen 528.

lorbeer 122, I39.

$-\operatorname{los} 325$. 
los $s b .264,356$.

los adj. 122, 406 .

loschen 80(MHG.), 92, 482.

lossen 123, 226(MHG.), 227, 293, 33०.

lotter I I 4 .

lowe 92, II2, I74, 23I, $237,382$.

lowenfell $3 \mathbf{r} 4$.

lowin 305 .

luchs $349,373$.

lücke 99,29 r.

Ludwig 399.

luft 258, 259, 298, 346.

lug III.

lüge $\mathrm{I} I 3,298$.

lügen $77\left(\mathrm{OHG}_{\text {. }}\right)$, Iro, 136, 493.

lust 346,381 .

lustig 322 .

lustwandeln 336 .

machen 105, $2 \mathrm{I}_{7}$ (OHG.), $246,288,528$.

macht I8(MHG.), 60 (OHG.), 79(MHG.), 93, 28r, 299, 375 .

mächtig 93, 163(OHG.). mädchen $300,356$.

mädelchen 300.

magd 79(MHG.), I 74, 391 .

mägdlein 307 .

magen $\mathrm{I} 74,383$.

mahd 280,346 .

mähen 120,280 .

mahlen 106, 18I, $5 \mathrm{Ir}$, 528.

mähne 90, I 74, 377 .

mahnen I 7 I (MHG.), 528.

mahnung 346,368 .

mähre 90, 107, 283.

Mai г 30, 1 74,386 .

maid 290.

maler 302.

malerisch 323 .

man 469 .

manch 226(MHG.), 292,

$372(\mathrm{OHG}$.), 469 .

mancherlei 426 . mangelhaft 320 .

mann I2(OHG.), 26, 90, 223 (OHG.), 35 r, $356,390$.

männchen 300 .

mannigfach 292, 424.

mannigfaltig 292.

männiglich 469 .

männlich 79(MHG.), 93, 324.

mantel 350 .

mantschen 343 .

märchen 120 .

mark $174,292,368$.

marke 346.

marschieren 488.

März 92, I 74, 262, 386 .

märzenveilchen $3 \mathbf{I} 4,386$.

mass I I $7,298,346$.

masshaltend 328 .

massholder 24.

mässigkeit 303 .

massregeln 25.

mast 349 .

matratze 346 .

matt I I5, 228, 406.

matte II 5 .

mauer 128, I $74,368$.

maus $4 \mathrm{r}$ (OHG.), 126,

ז27, 295, 39r.

maut $I 74$.

meer 107, 162(OHG.), I68(OHG.), 245, 246, 298.

mehl 108, 167(OHG.), $236(\mathrm{OHG}$.), 244, 365 . mehr 75(OHG.), 8I (MHG.), I2I, $2 \mathrm{II}$ (OHG.), 280, 4 ro.

mehrdeutig 328 .

mehrere 4 I0, 469.

mehrfach 424 .

mehrmals $55^{\circ}$.

mehrzahl $3^{\mathrm{I}} 3$.

meiden I09, I25, 48I, 485,490 .

meile r25.

mein 12(OHG.), 125, 434(OHG.),

(OHG.).

445

meinen I30.

meiner $43^{2}$. meinerseits 550 .

meinethalben 248,272 .

meinetwegen 248,272 .

meinige 447.

meist 4 Io.

meistens 549, 550 .

meistenteils 550 .

meisterhaft 320 .

meistern 330 .

meisterschaft, 3 ro.

meldung $\mathrm{I}_{72}$ ( $\mathrm{M} \mathrm{HG}$.)

melken 94, 286, 483 , 485,500 .

menge 92, 290, 299, 372.

mennig 243 .

mensch 26, 90, 92, I 74

(MHG.), 287.

merkwürdig 328 .

messen $263,484,509$.

messer 175,356 .

met I 15,379 .

metze 346 .

meuchelmord 127.

mich 432, 434(OHG.).

mieder 138 .

miete $7 \mathrm{I}(\mathrm{OHG}),. \quad 8_{3}$ (MHG.), I36.

mietsleute 314 .

milbe 235 .

milch I 7 (MHG.), 288, $39 r$.

milchmädchen $3^{1} 3$.

mild 95, r 74, 269.

milz 346.

minder $202(\mathrm{OHG}$.), 273 ,

4 ro.

mindern 340 .

mindest 4 ro.

minnen 528 .

minze 95 .

mir ro3, I6r, 432.

mischen 287 .

miss- 299,336 .

missachten 336 .

missbehagen 299,336 .

missbilligen 336,488 .

missbrauch 26, 299.

missbrauchen 336,488 .

missdeuten 336 .

missen $263,295$.

missernte 299.

missetat 299. 
missfallen 336 . missgestalt 26 . missglücken 336 . missgönnen 336 . missgunst 299. misshandeln 336,488 . misshandlung 26 . misskennen 336 . missklang 299. misslaut 299. missleiten 336 . misslingen 336 . missraten 336 . misstönen 336 . misstrauen 336 . missverstehen 336 . misswachs 299. mist 282 .

mit 95, I 7I (MHG.). mitgift 185 .

mitte 55(OHG.), 218 (OHG.), 267.

mittel 356 .

mittlerweile 550 .

mögen 79(MHG.), 98, IOI, II2, 200(OHG.), $218\left(\mathrm{OHG}_{\text {.) }}\right.$ 292, 534, 539.

möglich $324,546$.

mohn II8, 279.

möhre 283 .

molke 346,359 .

monat 118,184 .

mönch ror.

mönchtum 3II.

mond 38 (OHG.), II 8 , I6J (OHG.), 386. mondenlang 386 . mondenschein 3 I 4 . Montag I 8 , 174. moor 122.

moos 1 10, 356. morast 272. mord $275,346$. morgen 290. morgens 550. morsch 406.

mücke 79(MHG.), 99, 291,387 . mucksen 343 . müde 138, I 74, 400, 547. muhen III.

mühen $13^{8}, 181,242$, 280.

mühle I $13,174,280$.

mühsal 309 .

mühsam 326 .

mühselig 322 .

mulde 269 .

Münchener 302 .

mund 2 (OHG.), (MHG.).

mündung 3 I2.

münster 28.

munter 268, 327 .

münze 28, 95, I 74 .

mürbe 99, 235.

muskel 355 .

müssen I37, I38, I39, 200 (OHG.), 224, 534, 540.

muster 356 .

mut 137 .

mutig 322 .

mutmassen 330 .

mutter 79 (MHG.), 87 (MHG.), I37, I38, I39, I6I(OHG.), I62 (OHG.), 267, 299, 394 (OHG.), 396.

nabel 386 .

nach 22, 226(MHG.), $276(\mathrm{OHG}$.), 284. nachbar I 19, I39, I 84, 354,382 .

nachbarlich 324 .

nachbarschaft 310.

nachen 383 .

nachfolger 302 .

nachlässig 322, 328 .

nachlässigkeit 303 .

nachmals $55^{\circ}$.

nächst 549 .

nacht $\mathrm{r}_{3}, 93, \mathrm{I}_{92}(\mathrm{OHG}$.), 26o, 281, 298, 392.

nachtigall I74.

nachts $55^{\circ}$.

nachzügler 302 .

nacken 352 .

nackt $\mathrm{r} 74,406$.

nadel I I 7, I75.

nagel I7I(MHG.), I72
(MHG.), 244, 247, 290, 299, 374.

nageln 330.

nagen 5 II.

nah 4 ro.

nahe $279,284,4$ ro.

nähe 299,372 .

nähen 120, 280.

näherin 305 .

nähren I2(OHG.), 6o

(OHG.), 107, I6r

(OHG.), I62(OHG.), I63(OHG.), I64

(OHG.), $2 \mathrm{I}_{3}(\mathrm{OHG}$.$) ,$ 22 I (OHG.), 240, 243 (OHG.), 340.

nahrhaft 320 .

nahrung 3 r2.

naht 280 .

name I8, I06, I I 4, I 7 I

(MHG.), 246, 298, 346

(OHG.), 384 .

namentlich 272 .

narbe 235 .

narr 382 .

närrisch 323 .

nase I06, I 74 .

näseln 340 .

nass $316,406$.

nässen 330 .

natter I I9, I39.

natur 228.

nebelicht 32 r.

nebenzimmer $3{ }^{1} 3$.

neffe I08, I74, 192

(OHG.), 252, $25^{8}, 3^{82}$.

neid 125 .

neiden 490 .

neigen $278,290,490$.

nein 130 .

nehmen 6(OHG.), 59 (OHG.), 62(OHG.), 79(MHG.),8o(MHG.),

89, I08, I09, II4, II 7, I20, I6I(OHG.), 162 (OHG.), I 7o(MHG.), I 7 I (MHG.), I8I, 185, I86(OHG.), 224, 246, $247,280,47 \mathrm{r}(\mathrm{OHG}$.), $474,480,483,484$, 485,503 .

nehmer 302 . 
nelke I30, r39, 290.

nennen 92, 223, 268, 330, $53 \mathrm{I}, 532$.

-ner 302.

nerv 382 .

nervơs 28.

nest 56(OHG.), 80 (MHG.), 203(MHG.), 357.

netz I 74, 243(OHG.), 262,363 .

neu 77(OHG.), I27, I 74, 232(OHG.), 234, 316. neuerdings $55^{\circ}$.

neuigkeit 303 .

neulich 548 .

neuling 306.

neun $127,247,4$ I 3 .

neunte 268,422 .

neunzehn 4 I 3 .

neunzehnte 422 .

neunzig 4 I 3 .

neunzigste 422 .

nichte 259 .

nichts 469.

nichtsdestoweniger 469 .

nìchtswürdig 469.

niedlich 270.

niemals 550 .

niemand 272, 469 .

niere 346 .

niesen 495 .

nimmer 136, 139.

nirgend 272.

nirgends $55^{\circ}$.

-nis 24, 59, I 72, 308, 346.

nobel 406 .

noch 96,284 .

nochmals 550 .

nonne 97.

norden 274.

nordwest 26 .

not 122, 228.

nötig 322 .

nötigen $330,342$.

nüchtern I38, I39.

nummer $\mathrm{I} I 4$.

nuss 263,278 , 39 I.

nutz 298.

nütz 174 .

nutze Ioo. nutze 79(MHG.), roo, |pardel 349.

I74, 262.

nutzen 100, 352.

nützen 79(MHG.), 100.

ob 96, I7I(MHG.).

oben Iro.

obere 412.

oberlippe 313.

oberst I72(MHG.), 4I2.

obrist 412.

obst I 74, 264, 272.

ochs(e) I74, 282, 298, 382.

öde I23, I74, 547 .

odem II8, 246, 274.

oder r ro.

of en I I0, 350.

offen 105, 217(OHG.).

offenbar 318.

offentlich 272 .

offizier 28.

offnen 330 .

ofters 550 .

oheim 246.

ohne II8.

ohnmacht II8, 375 .

ohr 45(OHG.), $7^{6}$

(OHG.), 8I(MHG.), 122, I 74, 280, 298, 388.

$81 \mathrm{I} 74$.

onkel 349.

opfer $25 \mathrm{I}$.

ordentlich $28,272$.

ordnungsgemäss 328 .

originell 28 .

ort $35 \mathrm{I}$.

ostern 122, 209(OHG.).

otter I I $4,346$.

paar 228, 252, 356 .

pacht 252.

pack 252 .

palast 252, 272.

palme 252(MHG.).

panier 254, 346.

pantoffel 252, 355 .

papagei 252.

papier 28, 252.

papst 174,252 (MHG.), 272. partei 252, 30 I

passen 252.

pate (pathe), I15, I74, 252, 382 .

pause 252 .

pech 22, 252(MHG.).

pedell 252 (MHG.).

pegel 252.

pein I 74, 252(MHG.), 368.

peinigen 342.

pelz 252(MHG.).

perle 252(MHG.).

pest 252.

Petrus 390.

pfad 217(OHG.), 25I, $349,373$.

pfaff(e) $174,3^{82}$.

Pfalz 28.

pfau II $7,233,382$.

pfeffer $25 \mathrm{I}$.

pfeifen 492.

pfennig 250.

pferd 104, I73(MHG.), I 74 .

pflegen 108, 25I, 482, $483,485,508$.

pflicht $299,376$.

pflichtmässig 328 .

pflug 137.

pförtner 302 .

pfosten $3^{8} 3$.

pfote II5.

pfropfen 28.

pfuhl 349.

pfühl II3, 174 .

pfund 2I 7 (OHG.), 356.

piepen 252.

pilger 252(MHG.).

pille 252.

pilz I02, 254.

pinsel 252.

plage II 7,252 (MHG.).

plan 252.

plätschern 340 .

platt II5, 252, 406 .

platte II 5 .

plump 252, 406.

plumpsen 343 .

plunder 252.

pochen 252. 
pocke 252.

polster 254.

pracht 254.

prächtig 322.

prägen $254,288$.

prahlen 252.

prasseln 254.

predigen, 252(MHG.).

prediger 302 .

predigt 272.

preis 252(MHG.).

preisen 125, 252(MHG.), 490.

presse 295 .

priester I36, 252(MHG.).

priestertum 3 I I.

prinz $174,252,3^{82}$.

probe 139.

probieren 139.

prüfen $1_{3} 8,252$ (MHG.).

prügel 113 .

psalm $3^{8} 5$.

pudel 349.

pulver 252.

puppe 252(MHG.).

qual I 7,368 .

quälen ro8.

quarz ro4.

queck- 56(OHG.), I93

(OHG.), 224.

quelle $23 \mathrm{~J}$.

quellen $286,485,500$.

quendel 273 .

quer $23 \mathrm{I}, 274$.

quietschen 343 .

quitt II5.

rabe $174,215,353,3^{82}$.

rache II9, I39.

rachen 383 .

rächen 94, 506 .

rad 89, 106, 275, 357.

räder I08.

rädern 340 .

rałımen I 74, 346, $3^{8} 3$.

rand 268 .

rappe ${ }_{174}, 215,382$.

rasch 406.

rasen 383 .

rast $I 74$.

rat $120,298$. raten $\mathrm{I}_{2}(\mathrm{OHG}$.

(OHG), 7 I(OHG.), 83 (MHG.), I I $7, \mathrm{I}_{3} 6, \mathrm{I}_{73}$, $18 \mathrm{I}, 245,478,483$, $485,5^{1} 5$.

ratsam 326 .

ratschlagen $33^{\circ}$.

rätsel 309 .

raub I3I.

rauben 528.

räuber $\mathrm{I}_{32}, 302$.

räuberisch 323 .

raubvogel 3 I3.

rauch $13 \mathrm{I}, 288$.

räuchern 340 .

rauchfrei 328 .

rauchwerk 284 .

räude 127 .

raufen 133 .

rauh 284 .

raum 74 (OHG.), 8I (M HG.), 126.

räumen 79(MHG.), I27, 268.

räuspern I27.

rebe 346 .

rechnen $I 75$.

recht $\mathrm{I}_{3}$ (OHG.), 55, 192

(OHG. ), 28I, 356, 547 .

rechtfertigen 330 .

rechts $178,55 \circ$.

recke $174,3^{82}$.

rede 174,370 .

reden 107, I81, 528, 53 I.

redner 302 .

regelmässig 328 .

regen $108,247,299$.

regieren $34 \mathrm{I}$.

regierung $3^{1} 2$.

regierungsrat $3 \mathrm{I} 4$.

regnen 330,528 .

regnerisch 322 .

reh 284 .

reiben I09, I25, 490.

reich $125,174,288,363$.

reichtum $3 \mathrm{II}, 35 \mathrm{I}$.

reihen 490.

rein 174,278 .

reinigen 342 .

reinigung 3 12.

reinlich 324 .

reis 398 . reise 174 .

reissen $125,263,492$.

reiten I I4, I25, 267,

492.

reizen $26 \mathrm{I}, 262$.

rennen $268,53 \mathrm{I}$.

retten $53 \mathrm{I}$.

rettich 183,289 .

rettig $\mathrm{I}_{5} 5,289$.

reue $234,37 x$.

reuen 493 .

reuse 127.

reuten 127.

revier 346 .

richte 299.

richten 55 .

richter 302 .

richtig 322.

richtung 312 .

riechen $136,493$.

ried 270 .

riemen 383 .

riese I09, I 74, 293, 382.

riesengeduld 3 I4.

riesengross 328 .

rind 398.

ring 278,349 .

ringen 496.

rings $55^{\circ}$.

rinnen $\mathrm{I}_{7}(\mathrm{OHG}$.), 20

(MHG.), 97, 10г, 202

(OHG.), 223(OHG.),

$485,497$.

rinnsal 309 .

rippe $174,257,346$.

riss 298.

ritt 298.

rittertum 3 I I.

röcheln IOI.

roggen 2 I 5 (OHG.), 29I, 383 .

roh 122, 236(OHG.), $400,406$.

rohr 356 .

röhre 123.

röhricht 304 .

rose 346 .

ross $174,278,356$.

rost 174 .

rot 47 (OHG.), $\quad 76$ (OHG.), $8 \mathrm{r}$ (MHG.), I22, 2i2(OHG.), 316. 
rôte 299.

röten 330 .

rotte 115 .

rübe 138 .

ruchlos 137, 139.

rücken $99,218(\mathrm{OHG}$.), 278, 291, 36r.

rückkehr 26.

rückwärts $55^{\circ}$.

rüde $I_{13}, I_{74}$.

ruder 274 .

ruf $298,349$.

rufen 84 (MHG.), 136,

I37, 258, 485, 519.

ruferei 301 .

ruhm 137.

rühmen 531 .

rühren ${ }^{3} 38$.

rund 406.

rupfen 100.

russ 139.

rüssel I $_{38}$, I 39 .

russig 139.

rutschen 343 .

rütteln 340 .

saal ro6.

saat $70(\mathrm{OHG}),. \quad 8 \mathrm{I}$ (MHG.), 117, 299, 376.

sache 367 .

sacht 4, I 19, I39, 259, 406.

säen 79(M HG.), I20, I8I, 242, 53I.

saft 272.

säge 108.

sagen 106, I 74, I81, 190, $227,268,290,293$; 528.

saite 130,346 .

-sal 24, I 72, 309.

salben 4 (OHG.), I63

(OHG.), I 70 (MHG.), 527.

salm 386 .

salz 217 (OHG.), 262.

salzen 5 I4.

-sam 24, 26, 326, 406. same 384 . sammeln II4.

Samstag $26_{4}$. samt 469 .

sämtlich 469 .

sanft $4,316,406,547$.

sänger 302 .

sängerin 305 .

sarg 289.

satt II5, 406.

sattel $x I 4,350$.

satteln 330,370 .

sättigen 342 .

sattler 302 .

sau 4 I(OHG.), I26, 234,

391 .

sauber 126.

sauberkeit 303 .

säubern 340.

sauer I28.

säuerling 306 .

säuern 340.

saufen $8 \mathrm{I}$ (MHG.), I26, 258, 47 I (OHG.), 494 .

saugen 8 I (MHG.), 494 .

säugen 132 .

säugling 306.

säule 127,377 .

saum I 31 .

säumen 79 (MHG.), 127, 132.

säumig 127.

schaben 5 II.

schach I I9, 139.

schächer 120, I39.

schacht 259, 349 .

schade 384 .

schaden

287,528 .

schädigen 342 .

schädlich 324 .

schaf I I 7, I 74, 356 .

schäfer 120, 302 .

schaffen I37, I 73 (MHG.),

$$
5 \text { I2. }
$$

Schaffhausen $3{ }^{1} 5,393$.

schafgarbe $37 \mathrm{I}$.

-schaft $310,376$.

schaft 259.

schale 174 .

schalk 286 .

schallen 500 .

schalten 5 I4.

scham 106, 368 .

schämen 107, I I4, I 7 I schielen 283.
(MHG.), 202(OHG.), 287.

schande 268.

schar 106, I 7 I (MHG.)

scharf 9r, 25 I(MHG.), 3 I6.

schärfe 299, 372.

scharte 104.

schatten I I 4,236 (OHG.), 365,383 .

schattieren $34 \mathrm{I}$.

schatz I3(OHG.), 217

(OHG.), 26r(OHG.), 262.

schatzen 531 .

schätzen 53 I.

schau 368 .

schauen 131 , I92(OHG.), $234,528$.

schauer I28.

schaum 126.

schäumen 79 (MHG.).

scheel 283 .

scheere 298.

scheibe $3^{8} 7$.

scheiden $\mathrm{I}_{3}\left(\mathrm{OHG}\right.$.), ${ }^{1} 30$,

287,5 r6.

scheidung 3 I2.

scheinen I25,

(OHG.), 490.

scheitel 346 .

schellen 500 .

schelm 8o(MHG.), $3^{86 .}$

schelmisch 323.

schelten $269,483,485$, 498.

schemel II4.

schemen 383 .

schenken 92.

scherben 383 .

schere 120.

scheren 108, 485,503 .

scherge $174,240,383$.

scherz 94.

scheuer 174 .

schicht 376 .

schicksal 309.

schieben I10, 136, 287,

$485,493$.

schieber 302 .

schiefer 386. 
schiessen 122, 136, 139, 495.

schiff 64(OHG.), 217

(OHG.), 224, $25^{8}$

(MHG.), 356.

schifflein 307 .

schild 269, 379(OHG.).

schimmel II4.

schimmer II 4 .

schimmern 340 .

schinden 485,496 .

schinken $\mathrm{I} 74,383$.

schirm 64(OHG.).

schlacht 9I, I74, 299, 368.

schlaf 298.

schläfe 346 .

schlafen I3(OHG.), I7

(OHG.), 70(OHG.),

8I(MHG.), I17, 136,

I93(OHG.), 2I 7

(OHG.), 223(OHG.), $258,294,484$ (OHG.), $485,5^{15}$.

schlaff 406 .

schlafzimmer 3 r 3 .

schlag 298,374 .

schlagen 60 (OHG.) 79

(MHG.), 87 (MHG.),

I07, 22 I(OHG.), 48r, 485,5 I I.

schlange 346 .

schlank 406.

schlauheit 303 .

schlechterdings $55^{\circ}$.

schleichen 492.

schleife I 34 .

schleifen 125, 482, 492.

schleissen 492.

schleunig 127.

schlich 298.

schliessen 122, 136, 139,

495.

schlimm 256.

schlingel ro2.

schlingen $294,496$.

schlitten 114,383 .

schlittern 340 .

schloss 357 .

schlot 118 .

schlucht 259.

schluchzen 343 . schlucken roo.

schlummer II 4 .

schlummern 340 .

schlüpfern 340.

schlüssel 99.

schmach I 74, 284 .

schmähen 284 .

schmal I06, 406.

schmarotzen 24 .

schmatzen 343 .

schmeichelei $30 \mathrm{r}$.

schmeissen 125, 492.

schmelzen 94, 294, 482, 485,500 .

schmer 365 .

schmerz I74, 262, 294, 385 .

schmerzen 262, 501 .

schmettern II 4 .

schmiegen 493.

schmiss 298.

schnabel 350.

schnäbeln 340 .

schnalzen 343.

schnauben 494 .

schnecke 294, 346 .

schnee 75(OHG.), I2 I,

I $77,236,365$.

schneiden $8 \mathrm{r}(\mathrm{MHG}$.),

82(MHG.), II4, 221

(OHG.), 274, 294,

485,492 .

schneider 302.

schneidern 340.

schnell 294, 547 .

schnelle 299.

schnepfe 346 .

schneuzen 127.

schnitt II5, 298.

schnitte II5.

schnöde 174 .

schnupfen $3^{8} 3$.

schoffe 92.

scholle 346 .

schon 547 .

schön I8(M HG.), 79

(MHG.), I23, I 70

(MHG.), 174, 243

(OHG.), 287, 400,

406, 547.

schönheit $303,376$.

schopfen 80, 92, 200
(OHG.), $2{ }_{7}$ (OHG.), $25 \mathrm{I}, 287$.

schöpfer 80, 92, I72

(MHG.).

schoss 346 .

schote 115 .

schräg 174 .

schragen 383 .

schrauben 494 .

schrecken 504 .

schreiben $8 \mathrm{r}$ (MHG.),

82(MHG.), I09, I25,

I 73, I8I, 287,484 ,

485,490 .

schreiber 172(MHG.).

schreiberei 301.

schreibfeder $3 \mathbf{r} 3$.

schreibtisch 26.

schreien I25, 49I.

schreiten II4,

125 ,

492.

schrift 299, 376 .

schriftlich 324 .

schritt I I5, 374(MHG.).

schroff 406 .

schröpfen 92.

schrot 346 .

schroten 517 .

schub 298.

schuh 137, 284, 349 .

schuld $275,368,376$.

schuldig 79 (MHG.), roo,

292, 322.

schuldner 302 .

schüler 302.

schülerhaft 320 .

schulter 269.

schulze 174,382 .

schupfen roo.

schurke $174,3^{82}$.

schuss 298.

schütteln II 4 .

schütten II4.

schwach $3^{16 .}$

schwäche 299.

schwächen 330 .

schwachheit 303 .

schwägerin 305 .

schwäher ro8.

schwalbe 235 .

schwan 106, 386.

schwanenlied $3^{\mathrm{I}} 4$. 
schwanensang 386 .

schwang 298.

schwäre I08.

schwären 485, 503.

schwarte I04.

schwarz I3,OHG.), 231, 262, 294.

schweben 528 .

$\begin{array}{lll}\text { schweifen 130, } 198 & 198\end{array}$

(OHG.), 5I6.

schweigen 125, 290, 294, $482,490$.

schwein 39',OHG.), 72

(OHG.), 8I(MHG.), 125.

schweinefleisch 248.

Schweizer 302.

schwelgen 501 .

schwellen 208(OHG.), $482,485,500$.

schwer 120, I74, 316, 547.

schwere 297.

schwerlich 324,548 .

schwert 104, 269, 357 .

schwester 80(MHG.),

209'(OHG.), 23I, 294,

299, 394(OHG.), 396.

schwimmen 95, 97, 205

(OHG.), 223, 224, 246,

485,497 .

schwinden 485,496 .

schwingen 218 (OHG.), 496.

schwören 92, I12, 137,

I 7 I $($ M HG. $), \quad 230$

(OHG.), 485, 512.

schwund 298.

sechs $282,413$.

sechste 268,282 'OHG.), 408 (OHG.), 422.

sechzehn 296, 4 I 3 .

sechzehnte 422 .

sechzig 296, 4I3.

sechzigste 422.

see 8I(MHG.), I2I, 236, 298,365 .

seele I2(OHG.), 75

(OHG.), 8I(MHG.),

I2I, 236 (OHG.), 367 .

seemann 313 .

segel I $75,346,356$. segen 108, 293, 299.

segensreich 328 .

segnen 528.

sehen I3(OHG.), I08, 109, II7, 120, I 7 I (MHG.), 205(OHG.), 226(MHG.),

(OHG.), 279, 280, $284,293,48 \mathrm{I}, 485$, 507.

sehenswürdig 328.

sehne ro8.

sehr I2I, 280.

seide 125 .

seiden 3 r 9.

seife I30

seihen 22I(OHG.), 491. seil rзo, 356.

sein v. 39(OHG.), 225

(OHG.), 542.

seiner 437,438 .

seinethalben $248,272$.

seinetwegen $248,272$.

seinige 447 .

seite 125 .

seitwärts $55^{\circ}$.

sekt 272.

-sel 1 72, 309.

selbander 428.

selbdritt 428 .

selber 462 .

selbst 462 .

selbstlos 325 .

selbviert 428 .

selig 120, I72(MHG.), I83, 292, 405(OHG.), 408(OHG.).

seligkeit 303 .

seltsam $269,326$.

semmel II 4 .

senden $92,247,268,27$ I, 531.

sendung $3^{12}$.

senken I9(MHG.), 92,

53 I.

senne I 74 .

sessel 299.

setzen 13 (OHG.), 92, 217 (OHG.), 220

(MHG.), 26 $\mathrm{x}, 262$, $53 I$.

seufzen 127, 343 . sich 434(OHG.), 443, 444.

sicherheit 303 .

sicherlich I72,MHG.), 548.

sichtbar 318 .

sichten 259.

sie fem. 437.

sie $p l .437$.

sieb ro9.

sieben 62 'OHG.), 109, I63(OHG.), I66 (OHG.), 2I8(OHG.), $247,248,253,4$ I3, 42 I. siebente 268,422 .

siebzehn 248 , 4 I3

siebzehnte 422 .

siebzig 4 I3.

siebzigste 422 .

sieden II4, I36, 484, 495.

sieg rog, 379.

silbern 319.

simmer I02.

sims 264 .

singen $95,97,173,208$ (OHG.), 218 (OHG.), $250,293,485$.

sinken 208(OHG.), 250, $286,485,496$.

$\operatorname{sinn} 349$.

sinnen 97, I0I, 224, 485 , 497.

sippe 257.

sitte 115,162 (OHG.), 298, 346, 379.

sitz 298.

sitzen 55(OHG.), 70

(MHG.), 95, II 7, 2I7

(OHG.), 26 r(OHG.), 262, 5 Io.

sitzung 312.

sklave 174,382 .

sofort 27.

sohle 174 .

sohn I3(OHG.), 68 (OHG.), 79(MHG.), 80(MHG.), 97, 10I, IIO, II2, I6I(OHG.), I62(OHG.), I68 (OHG.), 2II(OHG.), 280, 293, 298, 379. 
söhnchen 300.

sőhnlein 307.

solch 288,463 .

soldner 302 .

sollen $287,534,538$.

söller Ir4.

sommer 97, II4, 224.

sonder $97,268$.

sonderbar $3^{1} 8$.

sonderling 306.

sonne 80'MHG.), 97, 346,387 .

sonnenschein $3^{8} 7$.

sonnenschirm $3 \mathbf{I} 4$.

sonnig 322.

sonntagskleid 314 .

sonst 97, 249, 272.

sorgen 528 .

sorgsam 326.

spähen I08, 192(OHG.), 528.

spahn I20.

spalten 269, 514.

span 117.

spannen 5 I 4 .

sparen 528 .

sparsam 326 .

sparsamkeit 303 .

spät 120, I74, 400, 406,

547.

spaten II 4 .

spatz 382 .

spazieren $34 \mathrm{I}$.

speer I2I, 346.

speien $75(\mathrm{OHG}$ ), I92

(OHG.), 236(OHG.),

$49 \mathrm{r}$.

sperber 235.

spiegel 7 I (OHG.).

spiel ro9, r 74, 356 .

spielen $294,528$.

spielerei 301 .

spindel 272.

spinne 298.

spinnen 97, ror, 224,

$251,485,497$.

spinner 302 .

spitze 251, 262.

spleissen 492 .

sporn 383 .

spott II 5 .

spötteln 340 . sprache $117,185,298$, 367.

sprechen I3 $_{3}$ (OHG.), 94, 96, I05, II 7, I20, I $7 \mathrm{I}$ (MHG.), I85, 186 (OHG.), 2I 7 (OHG.), 223 (OHG.) , 25I, 288, $294,485,504$.

spreizen 127.

spreu $232(\mathrm{OHG}$.), 346.

spriessen 495 .

springen 294, 496.

spritzen 102.

sprössling 306.

spruch $185,298$.

sprung 97, 298.

spucken, roo.

spule 346.

spülen ${ }_{13} 8$.

spülicht 304 .

spur III, 346 .

staat 355 .

staatsklug 328 .

stab 89, 106.

stachel 355 .

stacheln 340.

stadt 36(OHG.), 92,

II5, 162(OHG.), 27I,

375,377 .

städtisch 323 .

stahl 279, 280.

stählern 3 rg.

stallung $3^{12}$.

stammeln 340 .

stammler 302.

stand 298.

standhaftig 320 .

stark 9I, 286, 3 I6.

stärke 90, 108, 299, 372.

starr 406.

stätig 120.

stätte 115,377 .

staub I3r.

stäuben 132 .

stäublein $\mathbf{1 3}^{2}$.

stechen I 7 I (MHG.), 288, 294, 504 .

stecken $383,506$.

steg 89 , ro8.

stehen 87 (MHG.), I39,

173 (MHG.), I81, 268,

280, 485, 5 I I , 544 . stehlen 6I(OHG.), 80

(MHG.), I08, I7 1

(MHG.), 280, 294,483,

$484,485,503$.

steig 298.

steigen 43(OHG.), 75

(OHG.), 109, 125, 186

(OHG.), Ig2(OHG.), 218 (OHG. ), 478, 480

(OHG.), 484 (OHG.),

$485,488,490$.

stein 12(OHG.), 75

(OHG.), 247, 260,

294, 349 .

steinalt 328 .

steinern 319.

steinicht 321.

steinreich 26.

steiss 127.

stellen 239, 244.

sterben 79(MHG.), 94,

$96,99,294,485$,

498.

sterbezimmer 3 ז 3 .

sterblich 324 .

sterblichkeit 303 .

sterke 90.

stern I 74, 386.

stets 120,550 .

steuer 368 .

stich 298.

stieben 493 .

stiefel 355 .

still I 74, 547 .

stillschweigends $55^{\circ}$.

stimme 367 .

stinken 496 .

stirn 368.

stock 286.

stockblind 26 .

stolz 406.

stolzieren $34 \mathrm{I}$.

storr Ior, 386 .

storch 288.

stoss 298.

stossen 84(MHG.), I36,

485,5 I 7 .

stottern 340 .

stracks 550 .

strafbar 3 I8.

straff 406 .

strähle 346 . 
strähne I08.

strasse 117,367 .

strassenbahnwagen 29.

sträuben 127.

sträucher 127.

streben 108.

strebsam 326.

streicheln 340 .

streichen 492.

streit 125, 298.

streitbar 318.

streiten $484,485,492$.

streitig 322.

streng 92, I74.

streu $13^{2}$.

streuen 79(MHG.), 132, 232(MHG.), 234.

stroh 236 (OHG.).

strom 208(OHG.).

stube III.

stück 79(MHG.), 363.

stücklein 174 .

studieren 34I.

stufenweise 550 .

stuhl 137, 350.

stumm 97, 256, 406.

stummel 256.

stumpf 406.

stunde 268,367 .

stürzen 262.

stute 377 .

stutzen roo.

suchen 4(OHG.), 73

(OHG.), I37, 164

(OHG.), 170 (MHG.), 288.

südwest 26.

sühne 138 .

sünde 370 .

sündflut 95 .

sündig 322 .

süss 79 (OHG.), 138,

$\mathrm{I}_{74}, \mathrm{r} 82,230$ (OHG.),

$263,400,405$ (OHG.),

406, 408(OHG.), 547 . süssigkeit 303 .

tadelhaft 320 .

tadellos 325 .

tadeln 330, 340.

tag 13(OHG.),
(MHG.), 59(OHG.), 80(MHG.), 89, 106, I6I(OHG.), 162 (OHG.), I68(OHG.), I 70 (MHG.), 195 (OHG.), $2 \operatorname{II}(\mathrm{OHG}$.): 2I8(OHG.), 226 (MHG.), 227, 228, 266, 292, 298, 344(OHG.), 348.

tageszeit 174.

täglich 60,79 (MHG.), 324 .

tags 550 .

tal 357,398 .

tannicht 304 .

tänzeln 340 .

tapfer $3^{2} 7$.

tapferkeit 303.

tat 38(OHG.), 70

(OHG.), II 7, I95

(OHG.), 266, 299, 376.

taub 13 r.

taube $126,3^{8} 7$.

täuben 330 .

taubstumm 26.

tauen 274 .

taufe $133,372$.

taufen 79(MHG.), I33, 258.

täuf ling $132,306$.

taugen 536 .

täuschen 127.

tausend 74(OHG.), $8 \mathrm{I}$ (MHG.), 126, 274, 4I3, 4I5(OHG.).

tausendste 422 .

teil 82(MHG.), 13०, 228. teilen ${ }_{130}, 266$.

teilhaftig 320 .

teilnehmend 328 .

teuer 85(MHG.), 174, 400.

teufel 127, I7r(MHG.), 258, 264.

thron 349 .

tief 77 (OHG.), 84 (MHG.), 136, 193 (OHG.), 258, $3^{16 .}$

tiefe 299,372 .

r9 tier 136, r 74, 356. tinte 266.

tintenfass 314 .

tisch 178.

tischler 302 .

tochter 57(OHG.), 67

(OHG.), 79(MHG.),

80 (MHG.), 96, 98, 2 I8(OHG.), 260, 266, 28r, 299, 394(OHG.), 396.

tod 19 (MHG.), 76 (OHG.), $8 \mathrm{I}$ (MHG.), I22, I62(OHG.), 221 (OHG.), 226(MHG.), 275(MHG.),

(OHG.).

todkrank 328 .

toll I Io, 406 .

tölpel 274 .

ton 118, a74, 279.

tơnern 319.

tonne 97.

tor $(f \circ o l) 382$.

tor (gate), 57, I10,

174.

toricht $183,321$.

tosen 274 .

tot $122,218(\mathrm{OHG}$.), 221 (OHG.), 270.

tơten 330 .

traben 274 .

tracht 9r, 299, 368.

tragbar 318 .

träge 120,174 .

tragen 87 (MHG.), 90, 106, 137, 266, 290, $485,5 \mathrm{Ir}$.

träne 90, 107, 279, 346.

trank $185,298,346$.

traube 126,346 .

trauen $126,234,528$.

trauer 128,368 .

träufeln 132.

traum 86(MHG.), I3I, 350.

trăumen 79 (MHG.), I32, 268.

träumerisch $132,323$.

traut 126.

treffen 94, 96, I05, II 7 , 224(MHG.), 258, 504. 
trefflich 324 .

treiben 109, 125, 243, $253,490$.

treten I1 4, 120, I81, 260, 483,485 .

treu 127, 232(OHG.).

treue $234,37 \mathrm{I}$.

treulosigkeit 303.

trieb 298.

triefen 136,493 .

trift 299.

trinkbar 3 I8.

trinkbarkeit $з \circ 3$.

trinken I9(MHG.), 95, 185, 217 (OHG.), 250, $266,286,485,496$.

tritt II 5 .

trocken 327 .

trockenheit 363 .

trocknen 175 .

trommel 97, 256.

trommeln 340 .

tropf 386 .

tropfęn I 74, 215(OHG.), $25 \mathrm{I}, 383$.

trost I22.

trübe 138, I 74 .

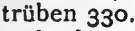

trübsal I 72(M HG. ), 3०9.

trübselig 322.

truchsess 120, I39.

trug 298.

trügen IIO, I $36,493$.

truhe III.

trümmer II4, 274.

trunk 97, I85, 298.

tuch 137 .

tugend III, 376.

-tum $3 \mathrm{II}, 35 \mathrm{I}$.

tummeln II4.

tun $137,181,543$.

tunlich 324 .

tür 35(OHG.), 57, 79 (MHG.), II3, 375, 377.

ubel $16_{3}(\mathrm{OHG}$.),

218

(OHG.), 253, 4 10 (MHG.), 547 .

über $55(\mathrm{OHG}$.).

uberall a7, $55 \mathrm{I}$. überbleibsel 309.

uberlang 328 .

übernachten 330 .

übernachtig 328 .

übersetzung 26.

uberzieher $3^{02}, 3^{13}$.

üblich 324 .

übrigens 550 .

uhr 356.

um roo, 256.

umfang 3 ז 3 .

umhalsen 5 I4.

un- 26, 299.

unart 299.

unartig 322.

unaufhaltsam 26.

unauf hörlich 26.

unbegreiflich 26 .

unberechenbar 26 .

unbilde 346 .

unbrauchbar 29.

und 97, I7I(MHG.).

undenkbar 26.

unecht 26.

unehre 299.

unendlich 26 .

unentgeltlich 26 .

unerträglich 26 .

unfall 299.

unfreundlich 26,3 I 7 .

unfruchtbar 26.

unfug 299.

-ung $24,172,312,346$.

ungehorsam 26 .

unglück 299.

ungnädig 26.

unhaltbar 26.

unhoflich $3^{\mathrm{I}} 7$.

unklar 26.

unkosten 299.

unlieb 26.

unmasse 299.

unmoglich 26 .

unrecht $26,299$.

unruhe 299.

uns $247,43^{2}, 434$.

unsäglich 26 .

unschơn 3 I 7 .

unschuld 299.

unser I 70(MHG.), 432,

434,445 (OHG.).

unserthalben 272 . unsertwegen 272.

unsrer $43^{2}$.

unstreitig 26.

untadelig 289.

untat 299.

unten 268.

unter $97,268$.

untere 412 .

untergang $3 \mathbf{3} 3$.

unterhaltsam 26.

unterhaltung 26 .

unterrock 313 .

untertan $355,3^{82}$.

Unterwalden 3 I 5,35 .

unterwegs $\mathbf{5 5 0}$.

unverschämterweise,

550.

unversehens 550 .

unvorsichtig 29.

unzahl 299.

unzählig 26, 289, 322 .

unzweifelhaft 26 .

üppig 257.

üppigkeit $3 \circ 3$.

ur- 299.

urahn 299.

uralt I 39,3 I 7 .

urbild 299.

urdeutsch 3 I 7 .

urfreude 299 .

urgrossvater 29.

urkraft 299.

urlaub 26, 299.

ursache 299.

urschrift 299.

ursprung 299.

ursprünglich 29.

urteil 25, I 39, 299.

urteilen 25,330 .

urvater 299.

urzeit 299.

vater $\mathrm{I}_{3}(\mathrm{OHG}),. 2 \mathrm{I}, 36$

(OHG.), 55(OHG.), 59'(OHG.),79'MHG.),

80'MHG.), I I4, I6I

(OHG.), $\mathrm{I}_{22}$ (OHG.),

I 75, I99(OHG.), 245,

258, 267, 299, 394

(OHG.), 395 . 
väterlich

324.

vaterlos 325 .

veilchen 356 .

ver- 337 .

verabschieden 337

verähnlichen 337 .

verallgemeinern 337 .

veralten 337 .

verankern 337 .

veranschaulichen 337 .

veranstalten 337 .

verarbeiten 337 .

verarmen 337 .

verausgaben 337 .

verband 299.

verbannen $5 \mathrm{I} 4$.

verbauen 337 .

verbergen 337 .

verbessern 337 .

verbinden 337 .

verbittern 337 .

verbleib 299.

verbleiben 337 .

verbluhen 337 .

verbluten 337 .

verbot 299 .

verbrämen 108 .

verbrauchen 337 .

verbreiten 337 .

verbreitern 337.

verbrennen 337 .

verdächtigen 337 .

verdauen 232(MHG.), 337.

verderben $337,482,485$, 498.

verderblich 317,324 .

verderbnis 308 .

verdeutlichen 337 .

verdienen 337.

verdoppelt 272 .

verdriessen 122, 136,

I39, 495.

verdruss 299.

veredeln 337,340 .

vereidigen 342 .

vereinigen 337 .

vereiteln 337 .

verewigen 337 .

verfeinden 337 .

verfeinern 337. verfertigen 337.

verfinstern 337 .

verfolgen 337 .

verfolgung $3^{12}$.

vergebens 550.

vergeblich $3^{17}, 324$.

vergegenwärtigen 337 .

vergehen 337 .

vergessen 105, 337, 509.

vergewissern 340 .

vergolden 337.

vergöttern 337.

vergraben 337 .

vergrossern 337,340 .

verhageln 337 .

verhältnis 308 .

verhältnismässig 328 .

verhärtet 182 .

verhehlen 337,506 .

verheilen 337 .

verheimlichen 337 .

verhelfen 337 .

verherrlichen 337 .

verhohlen 506 .

verhungern 337 .

verjagen 337 .

verjüngern 337 .

verkauf 299.

verklagen 337 .

verkleben 337 .

verkleiden 337 .

verkleinern 337 .

verkündigen 337 .

verlachen 337 .

verlassen 337 .

verlaufen 337 .

verläugnen 290 .

verlegenheit 303 .

verleihen 337 .

verleiten 337 .

verlieren 122, 136, 481, 495.

verlust $26,299,346$.

vermächtnis 308 .

vermeiden 337 .

vermitteln 340 .

vermogen 299.

vernachlässigen 337 .

vernageln 337 .

vernehmbar 318 .

vernehmen 337 .

vernunft 185,246 . vernunftig $246, \quad 3^{1} 7$,

322.

veröden 337.

veroffentlichen 337 .

verreden 337 .

versammlung $3 \mathrm{r} 2$.

versand 299.

versäumnis 308 .

verschămt $3 \mathbf{r} 7$.

verschieben 337 .

verschiessen 337 .

verschimpfieren $34 \mathrm{x}$.

verschlafen 337 .

verschleiern 337 .

verschlingen 337 .

verschollen 500 .

verschonern $337,340$.

verschroben 494 .

verschweigen 337 .

verschwenderisch 323 .

verschwiegenheit 303 .

versehen 337.

versenken 337 .

versiegeln 337 .

versilbern 337 .

versinken 337 .

versitzen 337 .

versorgen 337 .

verspielen 337 .

versprechen 337 .

verstand 26.

verständigen 337 .

verständigung 312 .

verständlich 324 .

verständnis 60,308 .

verstecken 337 .

verstehen 337,488 .

versteinern 337 .

versuchen 337 .

versuchung 3 ra.

verteidigen 250, 290.

vertrag 399.

verträglich 324 .

vertreten 337 .

verunreinigen 337 .

verursachen 337 .

verwachsen 337 .

verwandt $27 \mathrm{I}$.

verwandtschaft 27r, 3ro.

verwegen 508 .

verweis 299.

verweisen 264,490 . 
verwelken 337 . verwenden 337 . verwerten 337 . verwirken 337 . verwirklichen 337 . verwirren 501 . verworren 5 or. verzahnen 337 . verzaubern 337 . verzehren 337. verzeichnis 308 . verzeihen 48I, $49 \mathrm{I}$. verzinsen 337 . vetter 92, II4, 224, $3^{85}$. vieh 62(OHG.), rog, I62(OHG.), 279, 280, 380.

viel 62(OHG.), rog, 168(OHG.), (MHG.), 258, 4ro, 469,550 .

vielerlei 426 . vielfach 328,424 . vielleicht 139. vier I98(OHG.), 4I3. viererlei 426. vierfach 424. vierfältig 424 . vierfussig 328 . vierte 274,422 . viert(e)halb 427. viertel 136, r39. viertelstunde 26 . viertens 430 . vierzehn $139,328,4$ r3. vierzehnte 422. vierzig 139,4 13. vierzigste 422. vogel IIo, I65(OHG.), I 7 (MHG.), I 72 (MHG.), 244, 258, 290, 299.

vơgelchen 300 .

vöglein I72(MHG.), 3०7, 356.

vogler 302. volk ${ }_{13}$ (OHG.), (OHG.), 258, 298, 357. volksmässig 328 . volksparteiler 302 . volksrecht $3{ }^{1} 4$. volkstum 3 Ir. voll- 338 .

voll 5 I(OHG.), 57, 96, wägelchen 300 . 202 (OHG.), 224, 258, wagen 106, 299, 350. $316,406$.

vollblütig 328 . vollbringen 338 . vollenden 338 . vollends $55^{\circ}$. vollendung 26 . vollführen 338 . vollig 289, 322. vollmacht 26,375 . vollständig 26 . vollstrecken $33^{8}$. vollziehen $33^{8}$. von $96,258$. vonseiten $55 \mathrm{I}$. vor $57,103,258$. voralters 550 . voran 103, 139. voraus 139. vorder 274. vorderarm $3^{1} 3$. vordere 4 I2. vorhanden $3^{81}$, 551 . vormals $27,55^{\circ}$. vormund 275,35 . vorschriftsmässig 328 . vorsteher 302. vorstellung $3^{12}$. vorteil 139, $3^{13}$. vorteilhaft 320 . vortrefflich 26 . vorurteil 29. vorwurf 313. vorwurfsvoll 328 . vorzüglich 26 .

waare 174 .

wachen $2 \mathrm{r} 7$ (OHG.), 288.

wacholder 24 .

wachs 282 .

wachsen 6o(OHG.), 79 (MHG.), 93, 137, 139, 229(OHG. ), 282, 295, 5 II.

wacht 174 .

wächter 362 .

wade 346 .

waffe Ir9, 139, 346, 359. wägen ro8, 485,508 .

wagner 302 . wagnis 308 . wahl 298. wählen 90, 107, 280. wahn II 7 . wähnen 120. wahr II7, 280, 316, 406.

währen 108.

wahrhaftig 26, 320 . wahrhaftigkeit 26 . wahrheit 303 . wahrlich 324,548 . wahrscheinlich 26 . wahrscheinlichkeit 26 . waid 270. waide 130 . waise $130,346$. wald $274,275,35 \mathrm{I}, 379$ (OHG.).

walken $5 \mathrm{I} 4$. wallen 5i4. walten 244, 269, 5 I4. walzen 5 I 4 . wamme 256. wandeln $17 \mathrm{I}(\mathrm{MHG}$.). wandern 175 . wanderung $3^{\text {I2 }}$. wange 346,388 . wann 4,17 (MHG.). wappen I I 139. war 481, 507. warm 9I, 3i6. wärmen 6o(OHG.), 79 (MHG.), 93. warnung 3 I2. warten 9I, 528. was $9 \mathrm{r}, 16 \mathrm{r}(\mathrm{OHG}$.), $2 \mathrm{I} 7$ (OHG.), 220 (MHG.), 224, 263, 278,466 .

waschen $137,287,485$, $5 \mathrm{II}$.

wasser $217(\mathrm{OHG}$.), 263, 299.

wasserträger 313 .

waten II $4,267,5$ II.

weben I08, II8, 200 
(OHG.), 483, 485, 508.

Weber, 302, 360.

wechsel I72'MHG.), 282.

wechseln 340 .

weck $29 \mathrm{r}$.

wecken 21 7(OHG. ', 286 .

wecker 302 .

weder 278.

weg 6r(OHG.), 80

(MHG ), 89, 94, 108, 229(OHG.), 298, 349, 550.

weh $75(\mathrm{OHG}$.), I2I.

wehen I20, I8r.

wehmut 3 I3.

wehren I07.

weib 8I(MHG.), 125, $218^{\prime}$ 'OHG.), 298, 357. weiblich 324 .

weich 130.

weichen $125,288,482$, 492.

weigand I 72(MHG.). weihnachten $279,3^{15}$. 392.

weiland $184,272,55^{\circ}$.

weile 278 .

wein 125 .

weinen 130.

weise 174 .

weisen 490 .

weisheit $3 \circ 3$.

weiss 130, 202 (OHG.), $224,263$.

weissager 185 .

weisslich 324 .

weit 125.

weite 299, 372.

weitläufig 322.

weizen $262,36 \mathrm{r}$.

welch 80 (MHG.), 288, 468,469 .

welsch 93, 283.

welt 65 (OHG.), 376.

weltlich 324 .

wenden 223 (OHG.), 268,27 I, 53 r.

wenig I2I, 4IO, 469,

550.

wenigstens $549,550$. wenn 4.

wer 103, I08, I $7 \mathrm{I}$ (MHG.), I92(OHG.), $278,466,467,469$.

werben $99,485,498$.

werden $\mathrm{I}_{3}$ (OHG.), 94, 96, I04, I 7 I(M HG.), I8I, I92(OHG.), 221 (OHG.), 226(MHG.), $227,245,274,48 \mathrm{I}$, $483,485,498$.

werfen 79(MHG.), 99, I98(OHG.),

217

(OHG.), 25I, 485, 498.

werg 289.

werk I74, 21 7(OHG.), 286, 356.

wert I04, 275.

wesen 356 .

wesentlich 272 .

weshalb 467 .

wessen 466, 467 .

weswegen 467 .

wette 346 .

wetteifern $33^{\circ}$.

wetter $55,114$.

wichtig 322.

widder I I 4, 379.

wider II 4, I 7 I (MHG.).

wiebel rog.

wieder Ir4.

wiederkäuen 126, 493.

wiege 174 .

wiegen $482,483,485$, 508.

wiese rog.

wiesel rog.

wild 95, I 74, 275.

wildfremd 26 .

wildnis 308 .

wille $3^{84}$.

willfahren 488.

willkür ıoo.

wimper 247.

wind 55(OHG.), 95, 268.

winden $268,485,496$.

winter $260,299$.

wir I03, I6I, 432, 434.

wirken 286.

wirksam 326 . wirkung 312.

wirrsal 309.

wirt 95 .

wirtin I72(MHG.), 305,

370.

wirtschaft 3 ro.

wirtschaften 330 .

wirtshaus 174 .

wissen 6(OHG.), 12

(OHG.), 33(OHG.), 44(OHG.), 56 (OHG.), 64(OHG.), 66(OHG.), 80(MHG.), 95, 162 (OHG.), I85, 193 (OHG.), 200 (OHG.), 223 (OHG.), 263, 534,

535.

wissenschaft 3 ro.

wissenschaftlich 324 .

wissentlich 272.

witern II4.

wittib II $5,237$.

witwe 66(OHG.), 80

(MHG.), 23I, 387.

witz $185,262,346$.

wo 118,245 .

woche 56(OHG.), 65

(OHG.), 96, 288, $3^{87}$.

wochenlang 328 .

wöchentlich 272.

woge $I 18,346$.

wogen 118 .

wohl 65(OHG.), 80

(MHG.), IIo, I 7I

(MHG.), 280.

wohlan I39.

wohltat $3^{\mathrm{I}} 3$.

wohnen I Io, I 7 I (MHG.), 528.

wohnhaft 320 .

wölben 92.

wolf $5 \mathrm{I}$ (OHG.), 96, I6r

(OHG.), I62(OHG.), I98(OHG.), 221 (OHG.), 258, 298, 350.

wolfin 305.

wolke $96,346,359$.

wolle 68(OHG.), 96,

$202(\mathrm{OHG}$.), 223, 319.

wollen adj. 214, 319. 
wollen $v .545$. womit 467 . wonne 79 (MHG.), 97. worin 245. wort 162(OHG.), 218 (OHG.), 269, 344 (OHG.), 356, $35^{8}$. wortlich 324 . wovon 467 . wozu 467. wucher 137 . wuchs 298. wühlen 138 . wund 406. wunde 97. wunder 49 (OHG.), I65

(OHG.), 166(OHG.), I72(MHG.), 268. wunderlich 324 . wunderlichkeit 303 . wundern I66(OHG.), I 7 (MHG.), (MHG.). wundersam 326 . wunsch 97. wünschen 287,53 I. würde 95, 274. würdig 95 . wurf 298. würken 167 (OHG.), 200 (OHG.). wurm 68(OHG.), 80 (MHG.), 35I, 373. wurst 294. wurzel 262. wurzelhaft 320 . wurzeln 340. wüstenei 30 r. wut 137 .

zaghaftigkeit $з \circ 3$. zäh I 74. zahl I06, I7I(MHG.), 280, 367, 368(MHG.). zählen 239(MHG.). zahm 106, 316, 406. zähmen $107,330$. zahn I3(OHG.), 106, 28 o, 389. zahnlos 325 . zahnschmerz 3 r 3 . zähre 79 (MHG.), 107, 279, 346.

zapfen 383 . zart r04, 406. zärtlich 324 . zauber 346 . zaubern 133 . zaum $13 \mathrm{I}$. zäumen 132 . zehe I2r. zehn I08, 192(OHG.), I93(OHG.), (OHG.), $22 \mathrm{I}$ (OHG.), 262, 279, 316, 4I3.

zehnte 268, 422 . zeichen 130, I 72 (MHG.), $21_{7}(\mathrm{OHG}$.), 288.

zeichnung 312 .

zeigen 130,226 (MHG.), 290.

zeit 125, 261, 262, 298, 376.

zeitig 322.

zeitung 312.

zeitungsjunge 3 I 4 . -zen 343 .

zer- 339.

zerbersten 339. zerbrechen 339. zerbrechlich 317,324 . zerbröckeln 339. zerfallen 339. zerfleischen 339. zerfliessen 339. zerfressen 339. zergehen 339. zergliedern 339. zerhauen 339. zerkauen 339. zerklopfen 339. zerknicken 339. zerkratzen 339. zerlassen 339. zerlegen 339 . zermalmen 339. zernagen 339 . zerpflücken 339 . zerpulvern 339. zerreiben 339. zerreissen 339. zerrinnen 339 . zerschlagen 339 . zerschmeissen 339. zerschneiden 339. zersetzen 339. zerspalten 339 . zersprengen 339 . zerspringen 339 . zerstechen 339 . zerstören 339. zerstossen 339 . zerstreuen 339 . zerstückeln 339. zerteilen 339. zertrennen 339. zertreten 339. zertrümmern 339 . zerwerfen 339. zeug 127, 346. zeuge 174,382 . zeugnis 308 . zicke 346 . ziegel $7 \mathrm{I}$ (OHG.), 136. ziehen $76(\mathrm{OHG}), 79$ (MHG.), I Iо, I36, I92 (OHG.), I93(OHG.), $221(\mathrm{OHG}), 279,$.290 , 495.

ziel rog.

ziemen 108, II4, 246, 506.

ziemlich 324 .

zier 174 .

zierde 174 (MHG.). zieren 528.

-zig I99(OHG.). zimmer 256.

zinn rog.

zins 355 .

zither II4.

zittern II 4 . zögern 340 . zögling 306. zornig 322 . zote II5. zotte II5. zu 4.

zucht 299. zucken roo. zücken Ioo. zufrieden $55 \mathrm{I}$. zug I I I, 298. zügel 299. zugtier $3^{I} 3$. 
zuhanden $38 \mathrm{I}$. zuhaus $55 x$. zukunft 246. zunft 246 . zünftler 302 .

zunge 18, $97, \quad 16 \mathrm{I}$ (OHG.), x62(OHG.), I 70 (M HG.),

(OHG.), 247, 250, 346 (OHG.), 387 . züngeln 340 . zupfen Ioo. zürnen 99. zusammen II4. zusehends 550 .
Zwang 298. zwanzig 130, I39, 221 (OHG.), 4 I3. zwanzigste 422.

zwei 24I(OHG.), 23I, 4I3, 4's.

zweierlei 426.

zweifach 424 .

zweifältig 424 .

zweifel 13(OHG.), I25, $258,262$. zweifelhaft 320 . zweifeln I 7 I (MHG.). zweigliedrig 29. zweimal 425. zweispännig 328 .

zweite 422.

zweitens 430, 550 .

zwerchfell 274 .

zwerchpfeife 274 .

zwerchsack 274.

zwerg 266, 346 .

zwingen 208 (OHG.), 23o(OHG.), 23I, 274, $485,496$.

zwinkern 340 .

zwitter I 14.

zwolf 80, 92, 262, 4 r3.

zwölfte 422 . 
OXFORD: HORACE HART
PRINTER TO THE UNIVERSITY 




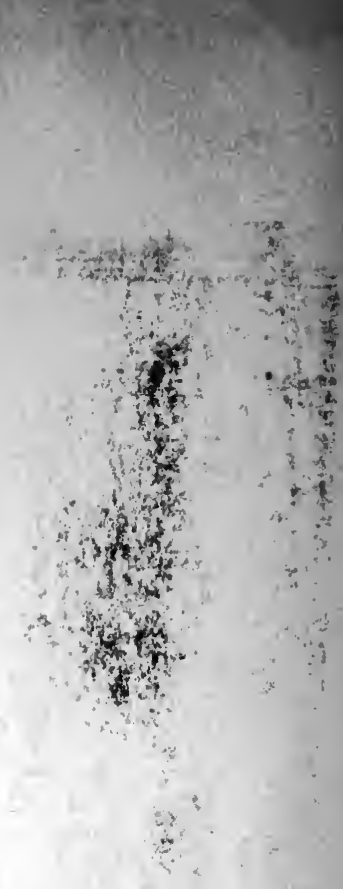

its is

a $4 y^{2}$

$1 \quad x^{2}$

$$
\begin{aligned}
& \therefore y^{x}=8 \\
& \text { सैำ } \\
& \because \text { t } \\
& \therefore \text { से कर } \\
& \text { ats } \\
& \text { ats } \\
& \text { ats }
\end{aligned}
$$




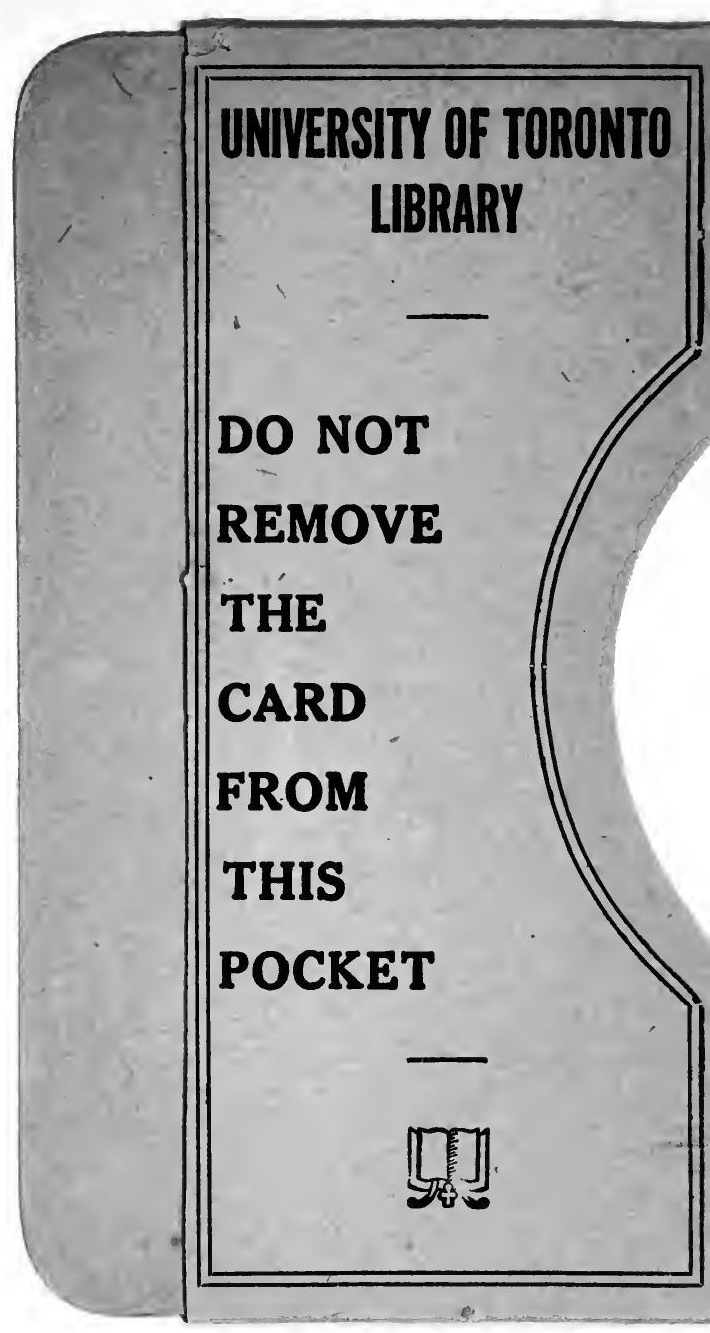


